\title{
Observando aves en el Perú: 1963-2006
}

\author{
Hansjakob Lüthi
}

Allmendstr. 4, CH-4460 Gelterkinden, Switzerland.

Email: htluethi@datacomm.ch

Presentado: $\quad 03 / 11 / 2010$ Aceptado: $\quad 23 / 03 / 2011$ Publicado online: $23 / 06 / 2011$

\begin{abstract}
In this paperwe present the observations and sightingsof birds carried out in 24 departments of Peru between 1963 and 2006. Information on the locations and altitudes is discussed for a total of 319 species from 62 families, and for some species are reported behavior, phenology and songs. $83 \%$ of the observations were made between 1963 and 1976 and 37\% correspond to observations made in the Department of Lima.

Keywords: Birds; Peru; distribution; habitat; behavior.

\section{Resumen}

En el presente trabajo se dan a conocer los avistamientosy observaciones de aves realizadas en 24 Departamentos del Perú entre los años 1963y 2006. Informaciónsobre las localidades y altitudes es comentadapara un total de 319 especies de 62 familias, además para algunas especies se informa sobre comportamientos, fenología y cantos. El 83\% de las observaciones fueron realizadas entre 1963 y 1976 y el 37\% corresponden a observaciones realizadas en el Departamento de Lima.
\end{abstract}

Palabras clave: Aves; Perú; distribución; habitat, comportamiento.

\section{Introduction}

As a teacher of Biology and German language at the Colegio Pestalozzi in Lima, the author lived in Peru from 1963 to 1973. Fascinated by the extraordinary diversity of Peruvian birdlife, he dedicated a large part of his spare time to birdwatching. He was lucky to count on the support of Maria Koepcke, a pioneering ornithologist of Peru. The author met her regularly at the Museum of Natural History to discuss his newest sightings. Travelling the Peruvian territory by all means of transports (and often by foot), he always had his binoculars and his notebook to hand. Although his interest covered all aspects of birdlife, he focused his attention on behavior related to reproduction, including vocal emissions, courting, nest-building, breeding and caring for the young. - Since returning to live in Switzerland in 1973, he has visited Peru several times, always aiming to enlarge his knowledge of the Peruvian birds.

In 2009 encouraged by Manuel Plenge, the author began to select and process the large amount of data, photos and drawings in order to prepare this publication. This paper reports on the main sighting and observations on 319 Peruvian birds made between 1963 and 2006.

\section{Material and methods}

This work follows the taxonomy and the order given in the List of the Birds of Peru by Manuel Plenge (2010). Species which were difficult to distinguish in the field have been excluded. Subspecies have not been considered.

Vertical distribution: In a considerable number of species the records of minimum and maximum altitude exceed the data of Birds of Peru (2007), referred to as BP; these figures are highlightend in bold, so are records concerning reproduction, as song activities, courting, nest-building, breeding etc.

Vocal emissions: It was adopted the standards used in BP in a slightly simplified form. Due to the difficulty of transforming birds' voices from the German to the English phonetic system, my notes differ in many cases from the ones given in BP.

Sites indicated as south/north of Lima are within a range of $20 \mathrm{~km}$ of Lima City. Lima City is referred to as urban Lima. Lima refers to the Department of Lima. Districts of Lima are identified with a slash, e.g. La Victoria/Lima. Sites without altitude indication are below $200 \mathrm{~m}$.

Photos and sketches by the author if not declared otherwise.

Glossary

lomas:

fog vegetation area totoral: gramadal: quebrada: community of Typha and Scirpus community of Distichlis and Sporobolus ravine; small tributary valleys of the Andes

$\begin{array}{ll}\text { Abbreviations } & \\ \text { ad(s). } & \text { adult(s) } \\ \text { alt. } & \text { altitude } \\ \text { ca. } & \text { circa/approximatly } \\ \text { ind(s). } & \text { individual(s) } \\ \text { juv(s). } & \text { juvenile(s) } \\ \text { occ. } & \text { occasion/occasionally } \\ \text { NP } & \text { North Peru } \\ \text { CP } & \text { Central Peru } \\ \text { SP } & \text { South Peru }\end{array}$

\section{Results}

TINAMIFORMES

TINAMIDAE

\section{Nothoprocta ornata}

02/05/1964. Near Corpacancha, Junín, 4400 m: Group of about 6 inds. in open Puna grassland.

04/12/1966. Chumcha, Santa Eulalia Valley, Lima, 4000 m: Ind. in open Polylepis wood.

29/06/1969. Watershed between Concepción and Comas, Junín, $4100 \mathrm{~m}$ : Group of 4 inds. in Puna grassland.

28/09/1970. Between Coracora and Parinacochas, Ayacucho, 3500 $\mathrm{m}$ : Several sightings in Puna grassland and barren rocky slope. When flushed, they emit a high-pitched di'di'di.

\section{Nothoprocta pentlandii}

\section{Sightings}

NP: Lambayeque (between Olmos and Abra Porculla), $600 \mathrm{~m}$.

CP: Coastal Valleys of Lima: Huaura 3000-3600 m, Rímac 19003000 m, Santa Eulalia 3000-3600 m, Mala 3500 m; most sightings around $3000 \mathrm{~m}$.

Habitat.- Semi-arid to humid montane scrub, humid montane forest, patches of agricultural areas; once in an Eucalyptus grove.

16/06/1963. Above San Bartolomé, Rímac Valley, Lima, 1900 m: 2 inds. flushed on the steep, scrub-covered slope. They hide some 200 
$\mathrm{m}$ away. A third ind. with at least $\mathbf{6}$ young in tow stops after a few hurried steps. With its crest raised it emits a soft call. The young respond to the luring ad. running for a short distance, then suddenly freezing for a while (virtually becoming invisible) before starting to run again.

26/03/1966. Chumcha, Santa Eulalia Valley, Lima, 3600 m: Several ind. in montane scrub. In the afternoon (16:30), several inds. call simultaneously: a soft., melodic tshewit.

08/06/1967. Chiuchín, Huaura Valley, Lima, 3000-3600 m: Several sightings in dense montane scrub with open, grass-covered patches; several young in different stages of development (Fig. 1).

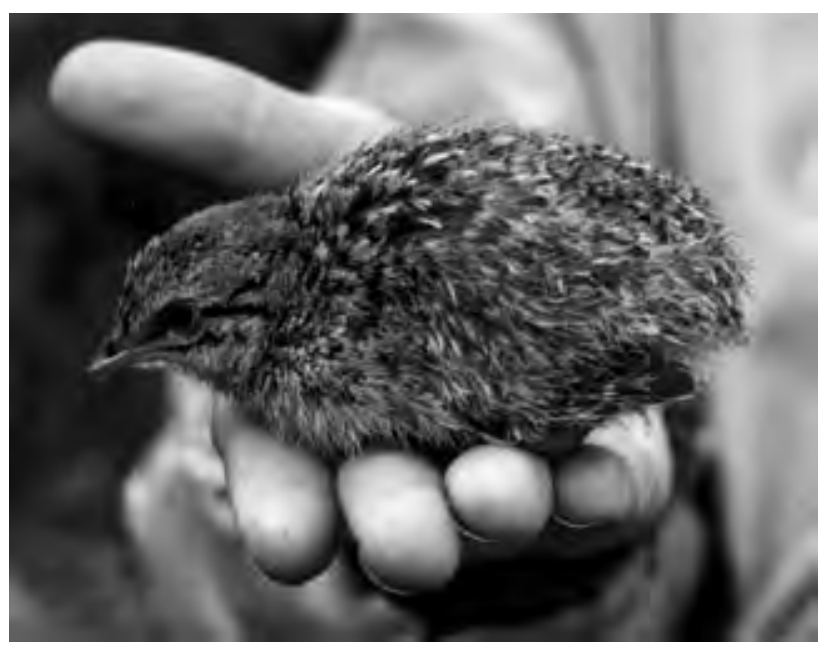

Figure 1. Fledgling of Nothoprocta pentlandii

\section{Tinamotis pentlandii}

Two voice records, no sightings.

26/03/1966. Chumcha, Santa Eulalia Valley, Lima, 4700 m: Very conspicuous song in a barren, scree-strewn landscape above Polylepis wood: kee...kiaw; first syllable hoarse and prolonged. Several separate inds. calling in chorus: As soon as an ind. starts, it is joined by the others. The song may last several minutes. When approached, they fall silent.

09/09/1969. Casta, Santa Eulalia Valley, Lima. 3800 m: Slope with low scrub, scree and dispersed boulders. Chorus song between 7 and 9 am kewa'kewa'kewa. It begins all of a sudden, lasts several minutes and ends as abruptly as it had begun. The birds remain invisible.

\section{ANSERIFORMES \\ ANHIMIDAE}

\section{Anhima cornuta}

19/01/1965. Rio Huallaga between Yurimaguas and mouth of Rio Marañón, Loreto: Pair on a sandy beach.

29/01/1973. Rio Utiquinilla, ca. $50 \mathrm{~km}$ north of Pucallpa, Ucayali: During a 6 hour-trip by boat about 12 ind. mostly in pairs; most numerous on the shore of a swampy oxbow lake; occ. song.

\section{ANATIDAE}

\section{Chloephaga melanoptera}

\section{Sightings}

CP: Ancash 4000-4300 m, Lima 3900-4500 m, Junín 4100-4500 $\mathrm{m}$, Ayacucho $4000 \mathrm{~m}$

SP: Ayacucho 3300/4200 m, Arequipa 4200 m, Cusco 4100 m, Puno 4000-4900 m

Lowest record: Laguna Parinacochas, Ayacucho, 3300 m; highest record: Ananaea, Puno $4900 \mathrm{~m}$.

Behavior.- Mostly in pairs or small groups (as stated in BP) but also gathering in large numbers, as shown in the following records:

26-29/06/1965. Laguna Conococha, Ancash, 4050 m: About 200 ind. sighted on both days.
08/06/1968. Between Puquio and Chalhuanca, Ayacucho, 4200 $\mathrm{m}$ : Very numerous.

28-29/09/1970. Laguna Parinacochas near Incahuasi, Ayacucho, 3300 m: Hundreds of ind.; often in pairs or groups of different sizes.

17/07/1976. Between El Puerto Pass and Ocongate, Cusco, 4100 $\mathrm{m}$ : Very numerous.

12/07/1979. Between Yauyos and Huancayo, Lima/Junín, 4200 $\mathrm{m}$ : Extraordinary numerous; forming pairs even when gathered in great numbers.

11/03/2003. Between Arequipa and Puno, 4000-4300 m: In large numbers at different locations.

\section{Merganetta armata}

Behavior.- Males often climb rocks and boulders using their stiff tails for support (Fjeldsa et al. 1990) in midstream or on riverbanks (possibly to express territorial claims).

21/07/1963. Santa Eulalia Valley, Lima, 1600 m: Male flying upstream.

29/02/1964. Mala Valley, Lima, $1400 \mathrm{~m}$ : Male standing on a pebble in shallow water. He glides into the water, first swimming upstreams along the riverbank then getting caught by the strong current, drifting downstream. Occ. he disappears in the turbulent waters, suddenly popping up again like a cork. Twice he niftily climbs up a boulder at rivers edge. Meanwhile, a female appears at the same place, where I had discovered the male before.- $500 \mathrm{~m}$ upstream another female is sighted, swimming in midstream.

15/05/1965. Santa Cruz de Laya, Lurin Valley, Lima, 2000 m: 4 inds. ( 2 males and 2 females) in a gorge of the fast flowing Rio Lurin. They are engaged in a courting ritual (Fig. 2). The males bob their heads back and forth and approach the females in an agressive manner. There is occ. a hissing sound, probably emitted by the males. Finally they withdraw, some flying, some swimming - even diving - against the stream.

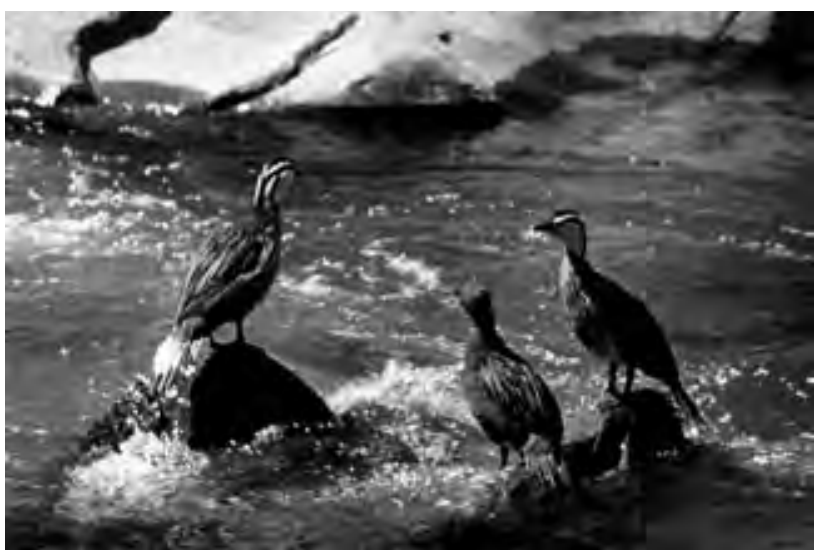

Figure 2. Merganetta armata: courting display of two males and a female.

$18 / 07 / 1965$. Pair at the same place; very shy. There is probably a breeding place at the upper end of the gorge, where there are many holes and crevices. Boulders and rocks are marked with droppings.

26/03/1966. Beneath Chumcha, Santa Eulalia Valley, 3300 m: Male flying downstream, passing beneath a small bridge.

09/12/1972. Rio Marañón, near La Unión, Huánuco, 3000 m: Male swimming along the river bank against the strong current, occ. by diving. On one occ. he climbs momentarily on a protruding rock.

14/07/1988. Achoma, Colca Valley, Arequipa, 3400 m: 5-7 inds. on a stretch of about $1 \mathrm{~km}$ of the Rio Colca; there are fast and quiet flowing sections. Among the sighted inds. are two pairs. Male and female elevate together when flushed. - Behavior of a single male: $\mathrm{He}$ swims, dives and occ. perches on one of the many polished, volcanic boulders in and along the stream. In one occ. he climbs a 1,50 m high boulder and slips down again in the next instant. For several minutes he stays on the calm side of a big boulder in midstream, foraging on algae, which cover the wet part of the rock. 


\section{Lophonetta specularioides}

\section{Sightings}

CP: Ancash: Santa Valley (Lagunas Conococha 4050 m, Pachacoto 4000 m, Yanganuco 3900 m); Lima: Huaura Valley 4000/4800 m, Chancay Valley 4300 m; Junín 4200-4400 m

SP: Ayacucho: Laguna Parinacochas $\mathbf{3 3 0 0} \mathbf{m}$ (on freshwater pond alongside the alkaline lake)

Behavior.- Predominantly on standing water (lakes, lagoons, ponds); on one occ. in a slow flowing stream. Mostly in pairs. Larger gatherings (up to two dozens) at the following sites:

26+29/06/1965. Laguna Conococha, Ancash 4050 m.

29/06/1969+12/07/1979. Between Concepción and Comas, Junín, $4400 \mathrm{~m}$.

29/11/1972. Chancay Valley, Laguna Aguashuman, Lima, 4300 m.

07/07/1979. Between Yauyos and Huancayo, Junín, 4200 m.

\section{Anas flavirostris}

\section{Sightings}

CP: Ancash 3900/4050 m (Fig.3), Lima 4000-4300 m, Junín 4100-4400 m

SP: Ayacucho 3300 m, Apurímac $\mathbf{2 7 0 0}$ m ( Laguna Huampica, Hacienda Toxama, north of Andahuaylas), Cusco 2800-3600 m, $3800-4300 / 4800 \mathrm{~m}$.

28-29/09/1970. Laguna Parinacochas, Ayacucho, 3300m: Hundreds - maybe exceeding one thousand - on the alkaline lake itself, its tributaries, on the shore and on small freshwater ponds.

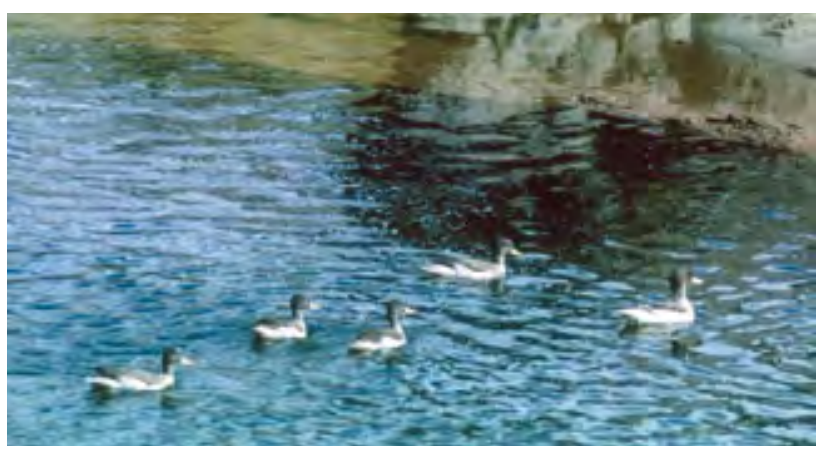

Figure 3. Anas flavirostris.

23/07/1988. Laguna Lucre, southwest of Cusco, $3100 \mathrm{~m}$ : Very numerous. An isolated group of 5 inds. is engaged in a courting display: They are eagerly swimming around in a muddled crisscross . Occ. some ind. (probably males) rise steeply out of the water, first with their head lowered to the breast, then stretching it with nape feathers raised, making the head look larger. Some are simultaneously flapping their wings. Others dip their heads into the water, then shake their plumage - as they do when bathing.

\section{Anas georgica}

\section{Sightings/Behavior}

CP: Junín 4200-4400 m, Ancash 4050 m, Lima 4300/4500 m.

SP: Arequipa sealevel, Puno 3800/3900 m, Cusco 3600 m.

Mostly in pairs or small groups; occ. in larger numbers.

30/04/1967. Between Carhuacayán and Junín, Junín, 4300 m: Very numerous on a medium sized lagoon.

03/02/1972. Camaná, Arequipa: At least 20 inds. on a long stretched lagoon in a mixed group with Anas bahamensis.

07/07/1979. Between Yauyos and Huancayo, Junín, 4200 m: Numerous on different lagoons.

12/07/1979. Between Concepción and Comas; Junín, 4400 m: Numerous.
18/07/1988. Near Chincheros, Cusco, 3600 m: Pair with 3 young on a shallow lagoon, about $300 \mathrm{~m}$ long and $20-30 \mathrm{~m}$ wide. One third is covered with reed and totora, the rest with floating waterweed. The family group goes instantly into hiding.

12/03/2003. Lago Titicaca, Puno, $3800 \mathrm{~m}$ : Quite common on the totora covered part of the bay of Puno; always in pairs.

10/04/2003. Upper Santa Valley, Rio Pachacoto, Ancash, ca. 4000 m: Not present on the Laguna Patacocha but in adjacent flooded area with small lagoons; groups of 3-4 inds. Three ads. with $\mathbf{5}$ dark grey young.

\section{Anas bahamensis}

Sightings.- From Tumbes to Arequipa; in small numbers on coastal lagoons of Lima (Villa, Chilca, Puerto Viejo).

06/01/1964. Rio Virú, Lambayeque: 30-40 pairs on the lagoon at the mouth of the river.

22/11/1966. Between San Juan and Villa, south of Lima: About 50 inds. in a mixed group with Anas discors in the middle of a lagoon formed recently by irrigation. Occ. they rise together for a short 'flight show' over the lagoon.

11/01/1972. Bay of Paracas, Ica: About 50 inds. on a mudflat in company of Phoenicopterus chilensis.

03/02/1972. Camaná, Arequipa: Very numerous on a long stretched lagoon in a mixed group with Anas georgica.

27/07/1979. El Salto north of Puerto Pizarro, Tumbes: 16 inds. on a marshy lagoon at the edge of a mangrove thicket.

\section{Anas puna}

\section{Sightings}

CP: Ancash 4050 m, Junín 4100-4400 m, Huancavelica 4300 m.

SP: Cusco 3100/3600 m, Puno: 3800-4300 m.

20-27/01/1972. Near Putina north of Lago Titicaca, Puno, 3900$4000 \mathrm{~m}$ : Next to Anas flavirostris the most numerous duck of the region. Ad. with young on Laguna de Checayani.

18/07/1988. Near Chincheros, Cusco, $3600 \mathrm{~m}$ : Two pairs on a long stretched, shallow lagoon, one third covered with totora and reed, the rest with floating waterweed. When foraging they dip their bills, at most their heads, into the food-loaded water, humming along softly. They 'grumble' when alarmed.

12/03/2003. Lago Titicaca, Puno, $3800 \mathrm{~m}$ : Common in the bay of Puno; often in pairs or small groups (4-5 inds.), on one occ. pair with 5 young.

\section{Anas discors}

Boreal migrant

22/02/1964. Paracas, Ica: 150-200 inds. in a shallow bay; they rest on the shore or swim close to it.

11/03/1964. Laguna Villa, south of Lima: In the afternoon they leave the totoral by and by. At $6 \mathrm{pm}$ there are at least 10 inds. ( 4 males) swimming in open water.

09/12/1964. Lagunas de Chilca, south of Lima: On two small lagoons 3 resp. 1 ind.

17/01/1966. Lagoon near Piura: Very numerous.

22/11/1966. Between San Juan and Villa, Lima: About 40 inds. on a newly formed lagoon by irrigiation in a mixed group with Anas bahamensis. Occ. they rise together for a short 'flight show' over the lagoon.

11/01/1967. Mouth of Rio Mala, Lima: 9 inds. on a small lagoon.

\section{Anas cyanoptera}

18/07/1988. Between Urubamba and Ollantaytambo, Cusco, $2800 \mathrm{~m}$ : Extended marshland with a shallow lagoon at the edge of Rio Urubamba: Group of 3 males and 4 females engaged in a courting 
display. A male begins by moving his head up and down in front of a female at a distance of $20-30 \mathrm{~cm}$. The female responds in the same way. A male about $1 \mathrm{~m}$ away participates in a 'contained' manner. The other females are seemingly not interested. There are occ. short persecution runs.

23/07/1988. Laguna Lucre southwest of Cusco, 3100 m: 2 pairs.

\section{Oxyura jamaicensis}

28/06/1965. Laguna Yanganuco, Ancash, 3900 m: A single male in open water. diving.

30/04/1967. Lago de Junín, 4100 m: Male near shore; escapes by

19/06/1968. Laguna Huampica, Hacienda Toxama, north of Andahuaylas, Apurímac, $\mathbf{2 7 0 0}$ m: About 12 inds. on the shallow, algae-infested lagoon; no totora.

27/04/1969. Santa Eulalia Valley, Lima: Laguna Milloc (4300 m) about 20 inds. on the shallow lagoon; the majority in a sleeping position (7:30 am), some are straightening their plumage. - Quite numerous on a small but deep lagoon $(4500 \mathrm{~m})$.

29/01/1972. Lago Titicaca, Puno, 3800 m: Rather numerous in the bay of Puno; two or three together, often in company of Fulica ardesiaca.

12/07/1979. Between Concepción and Comas, Junín, $4400 \mathrm{~m}$ : Several inds. in company of other waterfowl.

12/03/2003. Lago Titicaca, Puno, $3800 \mathrm{~m}$ : Common in the bay of Puno; numerous young in different stages of development. Nest with clutch (belonging to $O$. jamaicensis according to a native guide) in totora thicket: Platform of about $20 \mathrm{~cm}$ in diam. Two cream coloured eggs with irregular darkbrown streaks. Measures: 51x83/50x81 mm.

\section{Podicipediformes \\ PoDICIPEDIDAE}

\section{Rollandia rolland}

\section{Sightings}

CP: Lima coast/4300 m, Junín 3400/4100 m.

SP: Apurímac 2700 m (> 19.06.68), Cusco 3100/3600 m, Puno 3800/3900m.

Regularly on the coastal lagoons of Lima: Chilca (4x), Conchán (4x), Puerto Viejo (2x), Villa (1x), Cerro Azul (1x).

27/11/1963. Lagunas de Chilca, $65 \mathrm{~km}$ south of Lima: 4 ads. and $\mathbf{1}$ juv. on one of the many small lagoons.

09/12/1964. Same place: 8-10 ads. on different lagoons, 1 juv.

19/12/1967. Puerto Viejo, 70 km south of Lima: Pair with 3 juvs.

19/06/1968. Laguna Huampica, Hda. Toxama, Andahuaylas, Apurímac, $2700 \mathrm{~m}$ : Several ads. and some juvs. on the shallow, algaeinfested lagoon.

20-27/01/1972. Putina-Muñani, Puno, 3900 m: Fairly common on the many lagoons of the region; some juvs.

16/09/1972. Puerto Viejo: Fairly numerous; 12 inds. on a single lagoon; ads. with juvs.

12/03/2003. Lago Titicaca, Puno, 3800 m: Fairly common in the bay of Puno (even in the polluted part of it); singles, pairs, juvs.

\section{Rollandia microptera}

12/03/2003. Lago Titicaca, Puno, $3800 \mathrm{~m}$ : On a 5-hour-trip by boat in the bay of Puno we sighted 5-6 single ind.

\section{Podilymbus podiceps}

\section{Sightings}

NP: Lambayeque: On the river mouth lagoons of Rio Jequetepeque (Cajamarca) and Rio Virú (La Libertad).
CP: On the coastal lagoons of Lima: Between San Juan and Villa $(2 \mathrm{x})$, Conchán $(2 \mathrm{x})$, on the river mouth lagoon of Rio Mala (1x).

\section{Podiceps occipitalis}

Sightings/Habitat.- Most sightings in the La Viuda-Region (Upper Santa Eulalia Valley and Pampa de Junín) 4300-4700 m: 1-6 inds. in different habitats: On a deep water lagoon in a barren, rocky environment as well as on shallow lagoons in Puna grassland.

Sightings outside La Viuda-Region:

30/07/1966. Laguna Sausacocha near Huamachuco, La Libertad, $3100 \mathrm{~m}$ : Pair.

19/06/1966. Laguna Huampica, Hacienda Toxama, Andahuaylas, Apurímac, 2700 m: Several ads., some with young on the small, shallow, algae-infested lagoon.

July 1979. Between Yauyos and Huancayo, $4200 \mathrm{~m}$ and between Concepción and Comas, 4400 m, Junín: Present on different lagoons.

\section{PHOENICOPTERIFORMES \\ PheONICOPTERIDAE}

\section{Phoenicopterus ruber}

26/02/1965. Paracas, Ica: 2 inds.

24-26/02/1966. Same Place: Daily in varying numbers (1-6 inds.).

\section{3/02/1970. Same Place: 9 inds.}

28-29/09/1970. Laguna Parinacochas, Ayacucho, 3300 m: Probably several thousands on the shallow, alkaline lake. They are dispersed over the whole lake with a strong concentration near Incahuasi. At the end of the dry season, the lake has reached a very low level. There are numerous immature inds. Voice: a hoarse, gooselike gaggle, emitted especially early in the morning. Their movements are perfectly coordinated. When approached, they all behave like one ind.: They start moving together, change the direction together. Hundreds take flight at the same moment. In flight they form flocks of 20-30 ind. They spend the night standing on one leg on the mudflat.

11/01/1972. Paracas, Ica: 400-500 inds. in loose groups, about 1/3 immature. About 100 inds. have settled on the shore.

18-29/01/1972. Puno-Juliaca-Putina-Muñani, Puno, 3800-4000 $\mathrm{m}$ : Present in flocks of up to 40 inds. on several of the many lagoons of the region; two small flocks in the bay of Puno.

08-09/07/1988. Paracas, Ica: In groups of 6-15 inds., together less then 100 ind. When taking flight, they emit hoarse, coughing calls.

13/07/1988. Between Arequipa and Chivay, Arequipa, 4200 m: 9 inds. in extended marshland with countless lagoons.

12/03/2003. Between Arequipa and Puno, 4200 m: Small flock on a lagoon in Puna grassland.

\section{SPHENISCIFORMES \\ SPHENISCIDAE}

\section{Spheniscus humboldti}

4-5/01/1964. Between Paramonga and Huarmey, Ancash: At least a dozen inds. in an isolated bay enclosed by vertical cliffs. On both days 3 or 4 inds. are cavorting in the water, while the rest is on shore at the entrance (possibly also in the interior) of a cave. At $6.30 \mathrm{am}$ all are engaged in 'body-cleaning', be it on shore or splashing in the water. The latter turn occ. onto their back, scratching their belly with one wing, a procedure they really seem to enjoy.

26/02/1965. Peninsula Paracas, Ica: 3 inds. at the base of a high cliff in peaceful company of about 300 sealions. One ind. swimming near the cliff in the rough surge.

12/09/1965. Callao-Isla San Lorenzo, Lima (boat-trip): Groups of 2 or 3 inds. swimming; pair only $500 \mathrm{~m}$ away form the port entrance.

25/02/1966. Same place as 26/02/1965: 8 resp. 4 inds. at two neighbouring bays in company of numerous sea lions. They perch motionless on boulders, warming up in the sun. 
01/03/1970. Playa Caleta de Lobo, km 230, Panamericana Norte: Single ind. swimming close to the cliff line.

10-11/06/1972. Punta San Juan (protected area) between Nazca and Chala, Ica: The peninsula is a refuge to a major colony of $S$. humboldti. There are three seperate nesting sites (Fig. 4/5). According to the warden, there were 50-60 pairs breeding at the end of April. Considering the presence of only 40-50 young, it is evident, that the colony has been affected by the mass mortality of seabirds in the current year.

Site $\mathbf{I}$ is situated at the border of the plateau with about 25 nesting caves, placed side by side at the same level. The site is completly abandoned. There are two abandoned clutches with two eggs each; measures of one clutch: $57 \times 75 / 54 \times 71 \mathrm{~mm}$. The caves are $15-30 \mathrm{~cm}$ high, 30-40 cm wide, 50-80 cm deep.

Site II consists of about 90 superposed nesting caves. It is situated at the foot of the plateau, protected by high cliffs (Fig. 6). There are about 40 young of different sizes $(20-40 \mathrm{~cm})$, forming small groups of up to 10 inds. Each group is in custody of an ad. In our presence the young cluster together (Fig. 7) or seek shelter in a nesting cave. Their

(4)

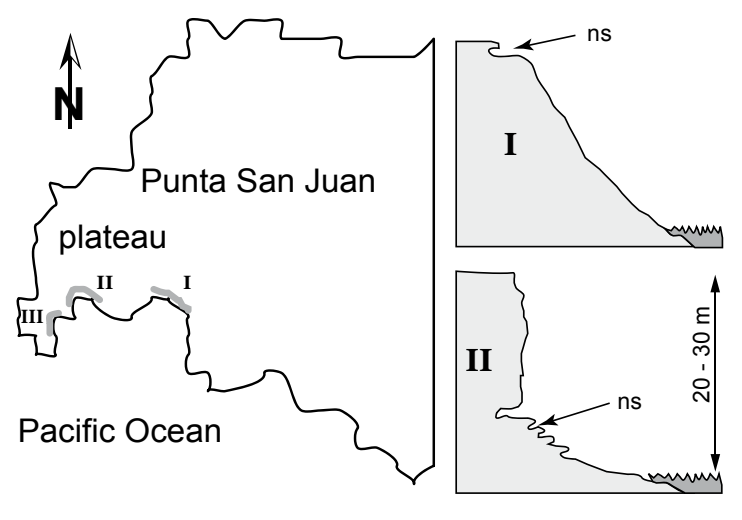

Figure 4/5. Punta San Juan: nesting sites of Spheniscus humboldti. Section through nesting sites.

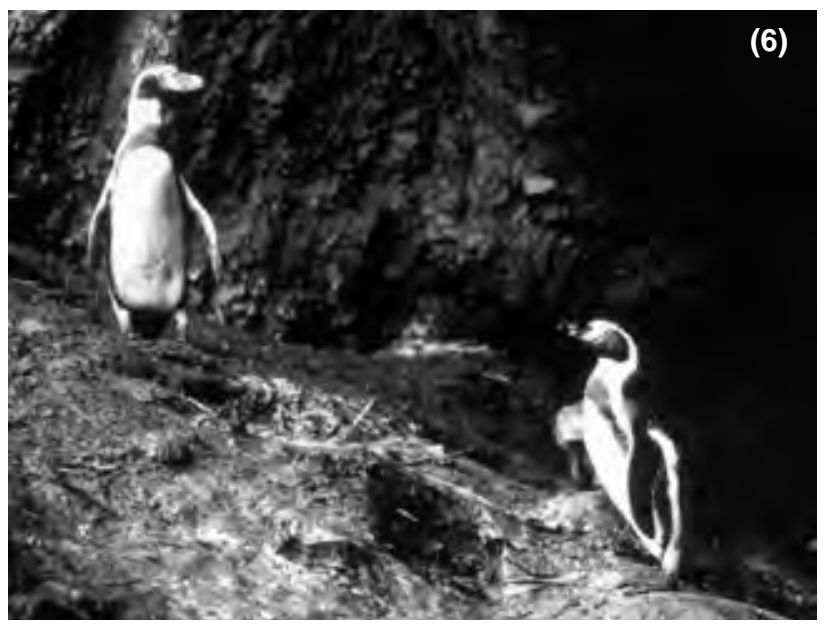

Figure 6. Adults of Spheniscus humboldti.

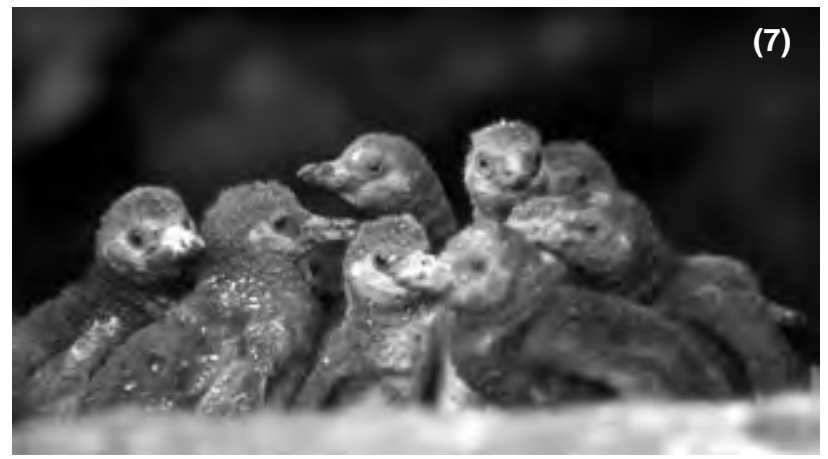

Figure 7. Clustering of young of Spheniscus humboldti. 'plumage' is clogged with dirt and excrement. By bending forward, they eject their droppings in a sharp jet, regardless of their fellow young. In the afternoon $(4 \mathrm{pm})$ the ad. population is engaged in feeding the young. About 15 ads. are present, some climbing ashore, just returning from their hunting trip. The young communicate with a constant cheeping, the ad. respond with a ventriloquist-like grumbling or a strong trumpeting sound (probably alarmed by our presence). When they feel menaced, they herd the young to the entrance of a refuge at the base of the cliff. Feeding ceremony: 2 or 3 young snuggle up to an ad., whilst expressing their urgency to be fed with delicate bites. Then they force their bills sidewise into the slightly opend bill of the ad.

Site III is - like site II - situated at the foot of the plateau and nearly inaccessible. It consists of about 12 nesting caves. We sighted 1 ad. and 3 young.

\section{PROCELLARIIFORMES \\ ProcellariIDAE}

\section{Macronectes giganteus}

12/09/1965. Callao-Isla San Lorenzo, Lima (boat-trip): Ind. swimming near the island.

\section{Daption capense}

12/09/1965. Callao-Isla San Lorenzo, Lima (boat-trip): Sporadic; ind. within the port area.

16/09/1972. Puerto Viejo, $70 \mathrm{~km}$ south of Lima: Exhausted ind. on the beach (with no apparent injury).

\section{Procellaria aequinoctialis}

07/08/1976. Ancón, Lima: Ind. in the bay of Ancón approaches the shore up to $100 \mathrm{~m}$, then rests for a while between the boats.

\section{Puffinus griseus}

12/09/1965. Callao-Isla San Lorenzo, Lima (boat-trip): Numerous; singles or in loose flocks.

Mass mortality of seabirds 1972 :

29-30/04/1972. Panamericana Sur, km 123, Lima: P. griseus is heavily affected: On a $300 \mathrm{~m}$-section of the beach there are 82 fresh carcasses; $\left(2^{\text {nd }}\right.$. place out of a total of 227 dead birds).

23/06/1972. Playa Chira, Chorrillos/Lima: No dead P. griseus in a total of 99 fresh carcasses on the $800 \mathrm{~m}$ long beach.

08/08/1972. Same place: 52 dead P. griseus out of a total of 312 carcasses $\left(3^{\text {rd }}\right.$ place).

16/09/1972. Puerto Viejo, 70 km south of Lima: 2 dead inds.; only a few other carcasses.

04/08/1983. Playa Conchán: A few dead inds.

\section{HYDROBATIDAE}

\section{Oceanodroma hornbyi}

16/02/1972. Urbanización California, Chosica, Rímac Valley, Lima, $800 \mathrm{~m}$ : Injured ind. found in a garden; some of the outer primaries of one wing are missing. It dies four days later. Length: $23.5 \mathrm{~cm}$ (Fig. 8).

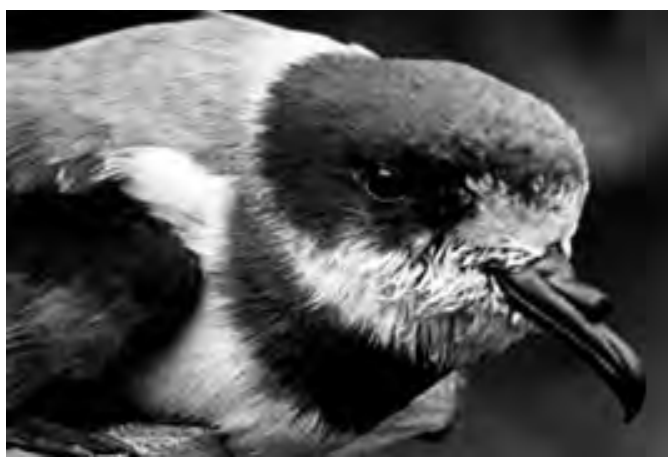

Figure 8. Oceanodroma hornbyi 


\section{Pelecanoididae}

\section{Pelecanoides garnotii}

21/09/1965. Callao-Isla S.Lorenzo, Lima (boat-trip): Numerous, but only singles.

\section{Pelecaniformes \\ Pelecanidae}

\section{Pelecanus thagus}

12/01/1972. Punta Lomas (protected area) between Nazca and Chala, Arequipa: Large breeding colony (according to the warden 28000 birds). Some nests still contain eggs or recently hutched young (Fig. 9); the rest of the young shows different stages of development (Fig. 10-12). The older ones are left without parental protection. Exposed to the merciless sun, they try to cool temselves by panting constantly. If approached, they emit eerie croaking sounds. During our presence $(11 \mathrm{am}-2 \mathrm{pm})$ there are only a few feedings. (See also Phalocrocorax bougainvillii)

Mass mortality of seabirds 1972:

29/04/1972. Panamericana Sur, km 123, Lima: On a 300 m section of the beach 2 dead P. thagus out of a total of 227 fresh carcasses.

23/06/1972. Playa Chira, Chorrillos/Lima: 15 dead inds. (one dying) out of a total of 99 fresh carcasses on the $800 \mathrm{~m}$ long beach ( $2^{\text {nd }}$ place)

08/08/1972. Same place: 5 dead inds. out of 312 carcasses.

16/09/1972. Puerto Viejo, $70 \mathrm{~km}$ south of Lima: No dead P. thagus, only a few carcasses of other species.

\section{SULIDAE}

\section{Sula nebouxi}

22/02/1968. Between Casma and Tortugas, Ancash: About 6 inds. on a rocky reef together with Pelecanus thagus and Phalocrocorax gaimardi.

29/04/1972. Panamericana Sur, km 123, Lima: On a 300 m long beach 5 dead inds. out of a total of 227 carcasses.

26/07/1979. Puerto Pizarro, Tumbes: Numerous on a long sandbank.

28/07/1979. Between Máncora and Zorritos, Tumbes: About 20 inds. on a cliff.

08/07/1988. Punta Pejerrey, Paracas, Ica: 2 inds. perched on a shipwreck.

31/03/2003. Tortugas, north of Casma, Ancash: Singles and small groups in flight over the bay.

\section{Sula variegata}

04-05/01/1964. Between Paramonga and Huarmey, Ancash: In the evening (until about $7 \mathrm{pm}$ ) there is an almost uninterrupted procession of $S$. variegata, Pelecanus thagus and Phalacrocorax bougainvillii northward. The birds are probably heading for their roosting place at the Punta Guanera of Huarmey. Between 5 and 6 pm several hundred inds. gather at a vertical cliff. They spend the night crowded on narrow ledges in company of a minority (10:1) of Phalocrocorax gaimardi. The next morning at 6 am most of them are still in a sleeping position. Some are straightening their plumage, some are leaving the cliff, others are returning to it.

11-17/02/1969. Playa Vineta, south of Paracas, Ica: Very numerous on the cliffs and on the rocky reefs dispersed in the bay. They dive as singles or in groups. In contrast to the normally practiced method - dropping from the sky like arrows - they are performing a slightly different technique: Single birds rise in a curve to a moderate height, turn downward and hit the surface of the water in a flat angle. They rise again a few moments later. One ind. manages to perform 47 divingflights in 5 minutes! (It had started before I began counting and it went on when I stopped counting).

29-30/04/1972. Panamericana Sur, km 123, Lima: On a 300 m long beach 97 dead inds.; $1^{\text {st }}$ place out of a total of 227 fresh carcasses
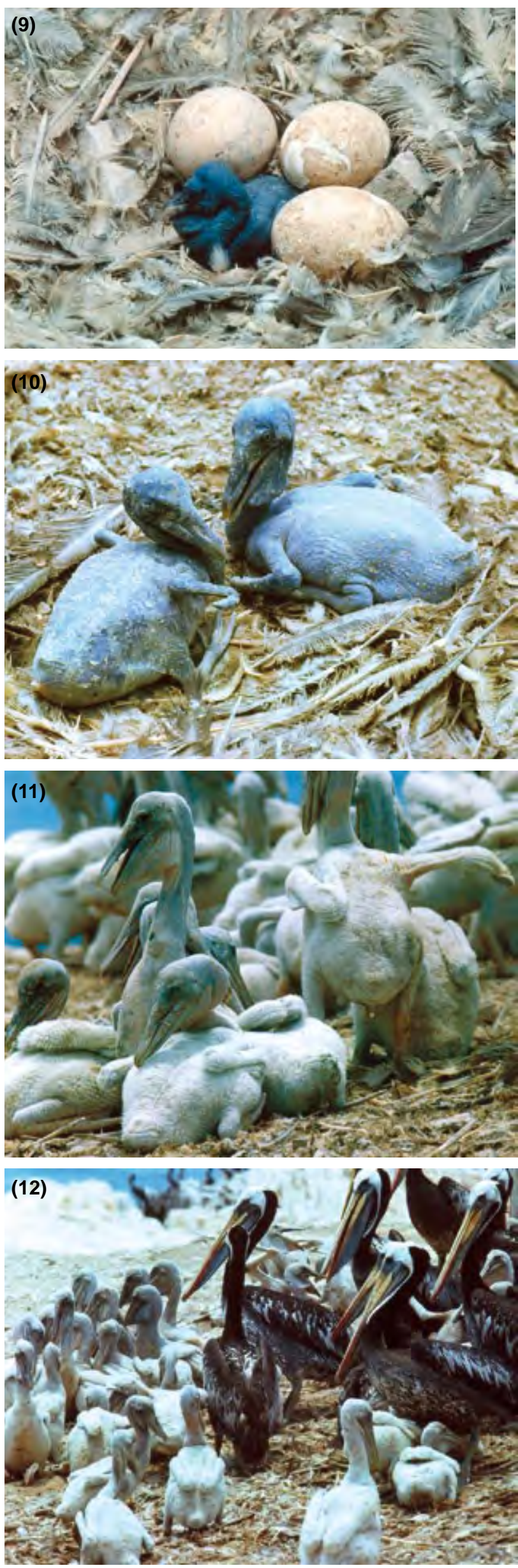

Figure 9-12. Young of Pelecanus thagus at different stages of development. 
of other seabirds. It is the most numerous species on the site. On one occ. there is a mass gathering offshore with spectacular, kamikaze-like diving-flights.

23/06/1972. Playa Chira, Chorrillos/Lima: 10 dead inds. (one dying) out of a total of 99 fresh carcasses ( $3^{\text {rd }}$ place).

08/08/1972. Same place: 84 dead inds. out of 312 carcasses $\left(2^{\text {nd }}\right.$ place).

16/09/1972. Puerto Viejo, 70 km south of Lima: Only a few dead inds., one dying.

08/07/1988. Islas Ballestas, Paracas, Ica: Very numerous; accounts for about $90 \%$ of all seabirds. Breeding: Nests on narrow ledges, each containing 2-3 white fledglings.

\section{PhALOCROCORACIDAE}

\section{Phalocrocorax brasilianus}

\section{Sightings/Behavior}

Coast: Tumbes, Piura, Lima, Ica.

Highland: Puno.

Eastern lowland: Ucayali, Madre de Dios.

Mostly in small groups, occ. in larger numbers.

April 1963. Playa Chira, Chorrillos: 100-150 inds. on cliff and rocky reef (birdrock) with smaller number of Pelecanus thagus, Phalocrocorax bougainvillii and Phalocrocorax gaimardi. Feeding of several juvs.

21-22/02/1964. Peninsula of Paracas, Ica: In flight and on shore; quite numerous at a shallow bay. A group of juvs. is warming up in the morning sun by spreading its wings.

11/01/1968. Mouth of Rio Mala, Lima: Singles or small groups, foraging near the shore; occ. flying upstream. (Recorded on three more visits at the same place; up to 20 ind. on nearby rock reef; 09/03/1971: many juvs.).

11-17/02/1969. Playa Vineta, south of Paracas, Ica: Resting and roosting site at the southern end of the bay, where up to 30 inds. gather on a slab.

08/08/1972. Playa Chira, Chorrillos/Lima: Mass mortality of seabirds: Only one dead ind. out of a total of 312 carcasses.

28/01/1973. Yarinacocha, Pucallpa, Ucayali, $200 \mathrm{~m}$ : Close flock of about 70 inds. circling over the lagoon; they depart in V-formation.

08/07/1988. Islas Ballestas, Paracas, Ica: Breeding: The untidy nests are situated on exposed places on rocky reefs. They consist mainly of large feathers.

\section{Phalocrocorax gaimardi}

\section{Sightings/ Behavior}

CP: Ancash, Lima (13 sightings out of 21), Ica.

Normally in small groups; in larger numbers at roosting and breeding sites; often in close neighberhood with Sula variegata, another 'cliff-dweller'.

23/11/1963. Playa Chira, Chorrillos/Lima: Food-carrying ind. approaching rocky headland.

18/10/1964. Puerto Viejo, 70 km south of Lima: Food-carrying ind. twice flying to nearby island.

24-28/02/1965. Peninsula Paracas, Ica: Several food-carrying inds. flying along the cliff.

25/02/1966. Same place: Large group of ads. and jusv. on an extended slab in company of Spheniscus humboldtii and sealions. It's feeding time.

29/02-05/03/1970. Playa Caleta de Lobo, Panamericana Norte km 230, Ancash: Numerous on neighbouring cliffs. Several ads. approach the cliff with nesting material (patches of seaweed). They disappear in a dark crevice. The nests, placed on narrow ledges, are made of seaweed and mud. No records of eggs or young.

08/07/1988. Islas Ballestas, Paracas, Ica: Several ad. carrying nesting material (stripes of seaweed). Nest sites: Narrow ledges protected from direct sunlight (niches, crevices, caves).

Mass decease of seabirds 1972: 29/04/1972. Panamericana Sur, km 123, Lima: 2 dead Ph.gaimardi out of 227 carcasses.

23/06/1972. Playa Chira, Chorrillos: 5 dead inds. out of of 99 carcasses.

08/08/1972. Same place: 3 dead inds. out of 312 carcasses.

\section{Phalocrocorax bougainvillii}

21/01//1968. Punta Lachay/Las Salinas, south of Huacho, Lima: Large colony of (according to the guard) 400000 birds. From a distance (we are not allowed to enter the protected area) they are blackening the top of the peninsula. In the colony reigns a restless coming and going. Some ind. carry long stripes of seaweed to their nesting places.

12/01/1972. Punta Lomas (protected area), between Nazca and Chala, Arequipa: There are only two small groups of breeding $P h$. bougainvillii (Fig. 13) at the edge of a large colony of Pelecanus thagus, counting by the thousands. The young are blackish, speckled with white down. Only one feeding scene in three hours: Ad. besieged by three young. - According to the guard, $P$. thagus regularly harrass $P h$. bougainvillii by destroying their nests or stealing nesting material. We witness the following scene: A $P$. thagus, sitting on its nest, reaches out to a neighbouring nest of $P h$. bougainvillii and - using its long bill as a rake - draws a batch of feathers to his side. Unimpressed by the protesting $P h$. bougainvillii, he repeats the maneuvre a second and a third time. - The statistics reveal a dramatic decline of breeding Ph. bougainvillii at Punta Lomas: 1965/66: 159 000, 1971/72: 1500 (probably the consequences of over-fishing in recent years). Presence of non-breeding birds at the site: 11:30 none; 14:00 in midst of the breeding P.thagus some isolated groups; numerous on rocky reefs and swimming offshore; 16:00 arriving by very large numbers at their roosting sites.

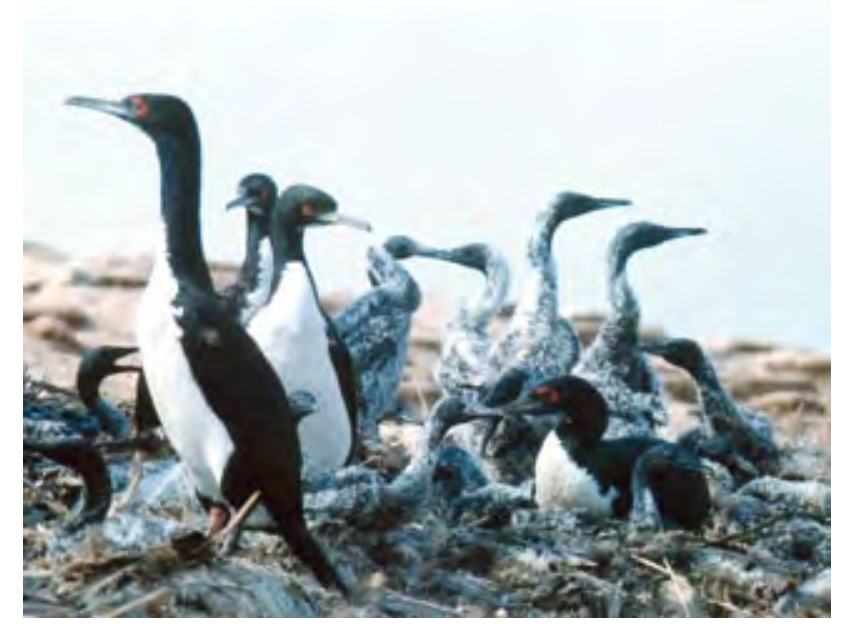

Figure 13. Phalocrocorax bougainvillii: adults and young

Mass mortality of seabirds 1972:

29/04/1972. Panamericana Sur, km 123, Lima: On a 300 m long beach 30 dead inds. out of a total of 227 fresh carcasses ( $3^{\text {rd }}$ place).

23/06/1972. Playa Chira, Chorrillos/Lima: On the $800 \mathrm{~m}$ long beach 64 dead inds. (1/3 immature) out of 99 carcasses ( $1^{\text {st }}$ place).

08/08/1972. Same place: 138 dead inds. out of a total of 312 carcasses ( $1^{\text {st }}$ place).

16/09/1972. Puerto Viejo, $70 \mathrm{~km}$ south of Lima: Only a few dead inds. on a $1 \mathrm{~km}$ long beach. 


\section{CICONIIFORMES}

ARDEIDAE

\section{Ixobrychus exilis}

Seven records between 1963 and 1967 at the Totoral de Villa, south of Lima: 1-3 inds. mostly at the edge of the totoral, occ. in the adjacent marshland. When disturbed they take flight or escape into the interior of the Typha-thicket, moving hurriedly from stem to stem.

06/08/1970. Conchán, south of Lima: Ind. at a small, newly emerged totoral as a result of the construction of a crossroad.

\section{Nycticorax nycticorax}

\section{Sightings/Behavior}

NP: Coast of Tumbes and Piura.

CP: Ancash 3900 m, Junín 4000-4300 m (most numerous), Lima coast/ $4300 \mathrm{~m}$.

SP: Apurímac 1300/2400/2700/2800 m, Cusco 3100 m, Arequipa 3400 m, Puno 3800-3900 m.

Solitary or in small groups of up to 10 ind; often ad. with juv. Does not mix with other herons.

22/11/1966. Totoral de Villa, south of Lima: At dusk 3 groups leave the totoral in short intervals: 1 ad. $+\mathbf{1}$ juv./ 2 ads. +1 juv./ 3 ads. A group of 6 inds. circles during 15 minutes over the marshland, occ. emitting their caracteristic huoc.

17-22/06/1968. Rio Toxamayo-Rio Pampas, north of Andahuaylas, Apurímac: 1 ind. at each of the following sites: Laguna Huampica 2700 m, Hacienda Toxama 2400 m, Rio Pampas 1300 m.

13-14/07/1988. Achoma, Colca Valley, Arequipa, 3400 m: At dusk $(6 \mathrm{pm})$ a small group leaves an Eucalyptus grove at the Centro Vacacional in direction of the nearby stream. Next morning at $7 \mathrm{am}$ they return to their roost. Before settling down, they draw some circles over the grove.

28/04/2006. San Bartolo, $50 \mathrm{~km}$ south of Lima: Juv. perches at the edge of a roof at the seafront.

\section{Butorides striatus}

\section{Sightings}

Coast: Tumbes, Lambayeque, Ancash, Lima, Ica.

Regularly in totorales (Villa!) and estuaries.

Eastern lowland: Loreto, San Martín (up to 800 m), Huánuco, Ucayali (most numerous in Yarinacocha/Pucallpa).

Behavior.- Mostly solitary; also in pairs and small groups. In eastern lowland on two occ. 'climbing' nimbly from branch to branch. Foraging: The neck retracted, body, head and bill in a perfect horizontal position, B. Striatus wades cautiously and in slow motion through shallow water (Fig. 14). Suddenly it freezes for some seconds, then throws its head flashlike towards its prey.

26/09/1971. Rio Fortaleza, Lima: 2 ads. and 1 juv. in a hunched position near the river mouth. Alarmed, they rise to their full size. After taking flight, they emit their hoarse call.

\section{Ardea cocoi}

\section{Sightings}

At each of the following sites 1 ind.

17/02/1967. Hacienda Mallares near Sullana, Piura: In flight.

11/01/1970. Rio Pachitea between Tournavista and Puerto Inca, Huánuco.

29/01/1973. Rio Utiquinilla, about $50 \mathrm{~km}$ north of Pucallpa, Ucayali.

21/02/2003. Rio Leche, Bosque de Poma, Lambayeque.

22/03/2003. Rio Madre de Dios near Puerto Maldonado, Madre de Dios.

\section{Ardea alba}

Sightings/Behavior.- Along the coast from Tumbes to Arequipa; in totorales, marshland and estuaries; very numerous in the ricefields of the north. Solitary or in flocks of up to 100 inds.; often in mixed groups with Egretta thula and Bubulcus ibis; less numerous in the eastern lowland; preferably at oxbow lakes (Yurimaguas, Pucallpa, Puerto Maldonado).

05/01/1964. Lower Santa Valley, Ancash: About 100 inds. in flooded ricefields; singles or in loose groups; some with elongated back feathers. An ind., that has just caught a mouse, takes flight, to escape some envious neighbours. At a safe place it waits till the mouse stops dithering. Then it lays the dead prey on the ground, grabs it again and swallows it with a flip.

04-05/01/1966. Puerto Casma, Ancash: At 6 pm 60-80 inds. are circling over the marshland at the river edge high in the air. By and by they gather on some large trees to roost. Next morning at 7 am they are foraging at the mouth of the Rio Sechín.

25+30/08/1968. San Juan de Miraflores, south of Lima: More than 100 inds. - some with elongated feathers on the back - at a large wastewater lagoon, which has been created a year ago in plain desert. It teems with small fish.

\section{Philherodias pileatus}

Single ind. at the following sites: Rio Llullapichis/Rio Pachitea, Huánuco; Yarinacocha, Pucallpa, Ucayali; Rio Utiquinilla, Pucallpa, Ucacyali; Rio Madre de Dios, Puerto Maldonado, Madre de Dios.

\section{Egretta tricolor}

02/01/1966+26/07/1979. Puerto Pizarro, Tumbes: Fairly numerous in the mangrove forest; solitary or in small groups of up to 8 inds.

\section{Egretta thula}

Sightings/Behavior.- Along the coast from Tumbes to Arequipa; in totorales, marshland, estuaries and irrigated areas (ricefields!); also at the lower reaches of coastal rivers (Rio Jequetepeque up to about 400 $\mathrm{m})$; on mudflats (Paracas), beaches and rocky headland adjacent to the beach (mouth of Rio Mala); often in mixed groups with Ardea alba, but in general more numerous.

Behavior.- Twice recorded rushing about in shallow water near the shore with flapping wings (to flush small fish, according to Fjeldsa \& Krabbe 1990). Courting display (or rivalry?): 2 or 3 ind. (probably males) performing vertical jumps in front of each other (up to $1 / 2 \mathrm{~m}$ ) with raised plumage on head and back; recorded twice in Sep, once in March.Totoral de Villa, south of Lima: At dusk, about 60 inds. settle down on the site to roost. A smaller group has already adopted its sleeping position at the edge of the totoral.

\section{Florida caerula}

Sightings/Behavior.- Coast of Tumbes, Lambayeque, Lima and Arequipa. Most numerous in the mangrove forest of Tumbes.

Lima: Solitary or in small groups in the totorales of Villa and Cerro Azul and at the mouth of Rio Mala; often together with other herons.

\section{THRESKIORNITHIDAE}

\section{Eudocimus albus}

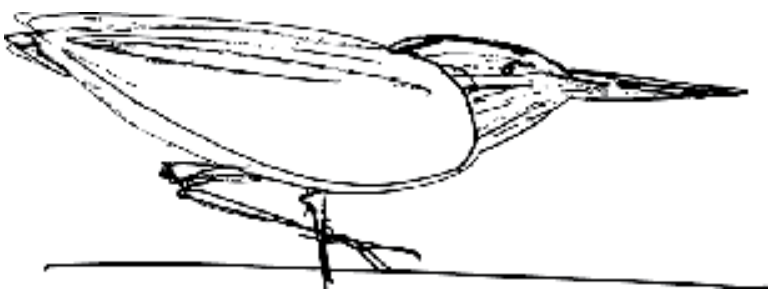

Figure 14. Butorides striatus. 
27/07/1979. Puerto Pizarro, Tumbes: Numerous; in groups of up to 12 inds.

\section{Plegadis ridgewayi}

\section{Sightings}

CP: Ancash 4050 m, Junin 3600/4100-4600 m.

SP: Aycucho 3300 m, Apurímac 2700 m, Cusco 3000-3600 m, Puno $3800-4300 \mathrm{~m}$, Arequipa $4200 \mathrm{~m}$.

Habitat/Behavior.- Lake sides, totora-covered lagoons, meandering streams, marshland, pastures, fields. Common in southern highland; often in pairs or flocks of up to 50 ind.

19/06/1968. Laguna Huampica, Hacienda Toxama north of Andahuaylas, Apurímac, 2700 m: Flock of about 10 ind. together with grazing horses.

15/03/2003. Below Abra La Raya, Puno, 4200 m: Conspicuous gathering of 50-100 ind., crowded on a circular patch of barren ground.

\section{Mesembrinibis cayennensis}

29/01/1973. Rio Utiquinilla, $50 \mathrm{~km}$ north of Pucallpa, Ucayali: Ind. in flight over swampy oxbow lake.

\section{Theristicus caudatus}

20-23/01/1972. Putina, Puno, $3900 \mathrm{~m}$ : Twice 4 inds. at the same site, foraging at the shore of a meandering stream. Without looking up, they poke the humid ground incessantly with their long, curved bill, occ. pouncing it forward forcefully. - Two inds. in flight between Putina and Muñani.

\section{Platalea ajaja}

11/01/1966. Puerto Pizarro, Tumbes: 3 inds. foraging in shallow water at the edge of the mangrove forest.

\section{Cathartiformes CATHARTIDAE}

\section{Cathartes aura}

Sightings.- Sightings above 2200 m (BP: "only a vagrant to the high Andes”): Viuda-Carahuacayán, Junín, 4600 m; Zárate, Rímac Valley, Lima, 3000 m; Fortaleza Valley/Santa Valley, Ancash, up to 4300 m; Chicama Valley, La Libertad, up to 3000 m; Huamachuco, La Libertad, $3300 \mathrm{~m}$.

29/02-05/03/1970. Caleta de Lobo, Panamericana Norte, km 230, Ancash: Numerous, especially on the reef in front of the beach, together with half a dozen Vultur gryphus. They calmly walk about in midst of 300 sea lions. Up to 9 inds. foraging on a dead sea lion (Fig. 16).

\section{Sarcorhamphus papa}

Mid September 67: Between Rio Marañón and Rio Cenepa, Amazonas, between 500 and $1000 \mathrm{~m}$ : Ind. in flight over densely forested hills.

\section{Vultur gryphus}

\section{Sightings}

CP: La Libertad 100 m, Ancash 0/1600 m, Lima 0-4300 m, Ica coast.

SP: Cusco 2600/2700 m; east slope: Machu Picchu, Cusco, 3000 m.

Fourteen out of total of 41 sightings refer to the Coast; regularly at the Peninsula of Paracas, Ica (Fig. 15); up to 5 inds. simultaneously.

Lomas of Lima: 3 sightings (Lachay, Atocongo, Pacta)

Coastal valleys of Lima: Huaura, Canta, Rímac-Eulalia, Mala; at all altitudes up to $4300 \mathrm{~m}$; regularly around Casta, Santa Eulalia Valley, $3100 \mathrm{~m}$.

25/05/1963. Watershed between Rímac and Lurin Valley, ca. 2000 m, Lima: Ad. and immature glide close over our heads along slope with scarce vegetation. Their enormous wings produce an impressive sound. The ad. flies the same stretch several times, turning his head and long neck from one side to the other, watching out for some carrion. Mistaking it for a potential enemy, a scared vizcacha (Lagidium peruanum) takes refuge beneath a slab.

07/01/1964. Panamericana crossing Jequetepeque Valley: Ind. circles over a carrion at the road side. A mixed group of Cathartes aura and Coragyps atratus and a single Caracara cheriway are already feeding on it.

07/02/1964. Playa de Chilca, $65 \mathrm{~km}$ south of Lima: Ind. feeding on a dead dolphin together with 4 Cathartes aura.

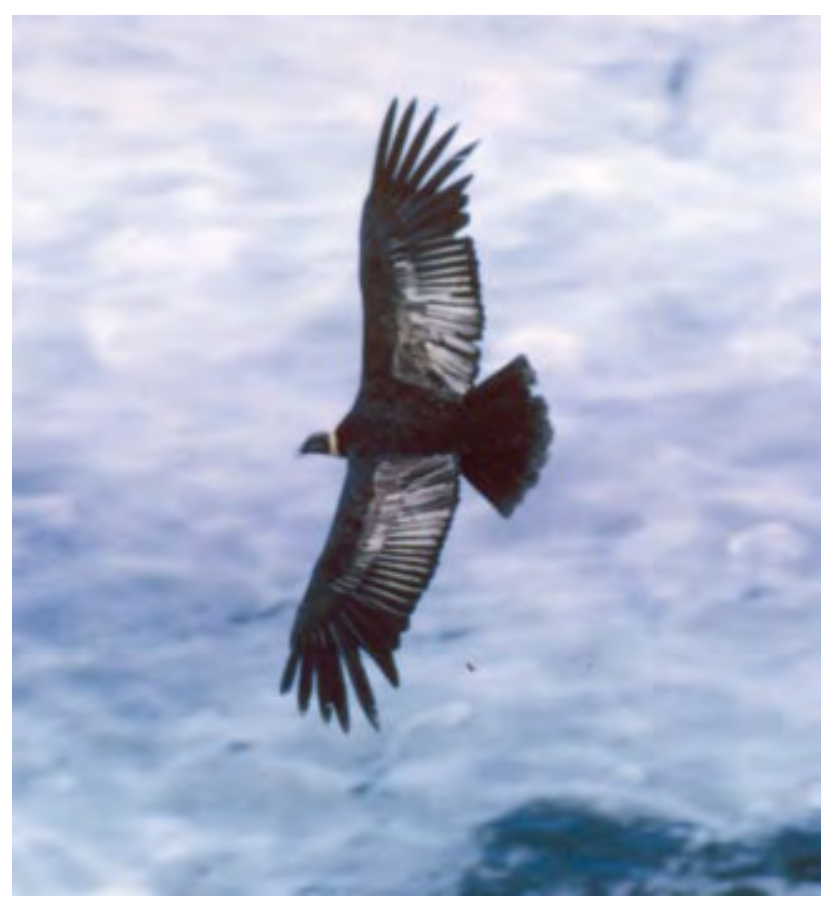

Figure 15. Vultur gryphus.

25-27/03/1966. Quebrada Huachugua, Santa Eulalia Valley, Lima, 3400-4000 m: 1-3 ind. almost permanently over montane scrub and Polylepis wood, often scanning the ground at close range. - At 8 am a close group of 22(!) inds. pass by over a distant ridge.

05-12/09/1969. Casta, Santa Eulalia Valley, Lima, 3100 m: Up to 4 inds. (ads. and immatures) almost daily over the village. They like to soar in the thermal at the edge of the village over a $1000 \mathrm{~m}$ high cliff-like slope.

29/02-05/03/1970. Playa Caleta de Lobo, Panamericana Norte, Ancash, km 230: Up to 6 ads. roost regularly on a reef in front of the beach in close neighborhood with 300 sea lions (Fig. 16). In the morning, when the fog begins to disappear and the sun is breaking through, they spread out their wings in a really majestic manner.

\section{ACCIPITRIFORMES}

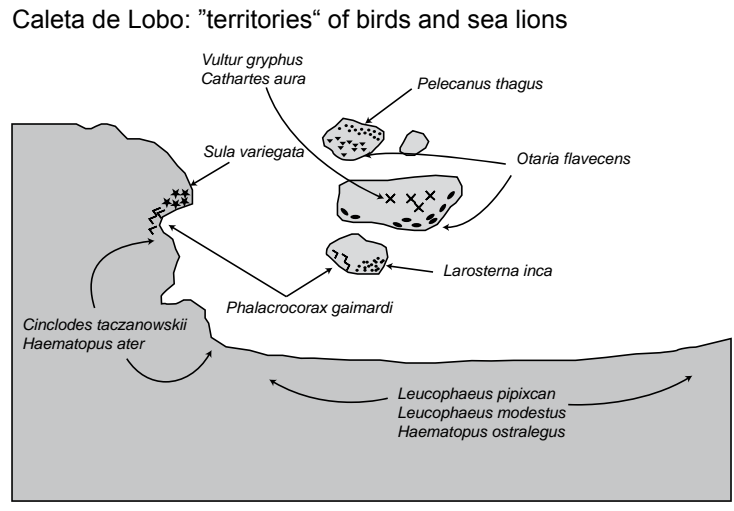

Figure 16. Colony of sea lions attractsVulturgryphus and Cathartes aura. 


\section{PANDIONIDAE}

\section{Pandion haliaetus}

Boreal migrant

\section{Sightings}

Coast: The main season is mid Nov to end of Feb with a clear culmination in Jan; sporadic in June (3x), Aug (1x), Oct (2x). Regularly present in Jan/Feb at the Peninsula of Paracas and the adjacent bays to the south (Fig. 17-19).

Most records over bays and along beaches; occ. at rivermouths and lagoons; twice over an artificial lake in La Molina, Lima.

Eastern lowland: Rio Pachitea and Rio Utiquinilla (Pucallpa region).

31/11/1963. Parque Central, Miraflores, Lima: Ind. circling over two high Araucaria. It settles on a lower branch and begins to gorge its prey. Remains of fish beneath the tree reveal, that it must be a regular feeding place.

24-28/02/1965. Peninsula of Paracas, Ica: Appears daily over the bay of Lagunillas; up to 3 inds. at a time. Only one succsessful dive recorded. After emerging from the water, it stops in mid-flight, contracts its wings and shakes its plumage forcefully. When in company,
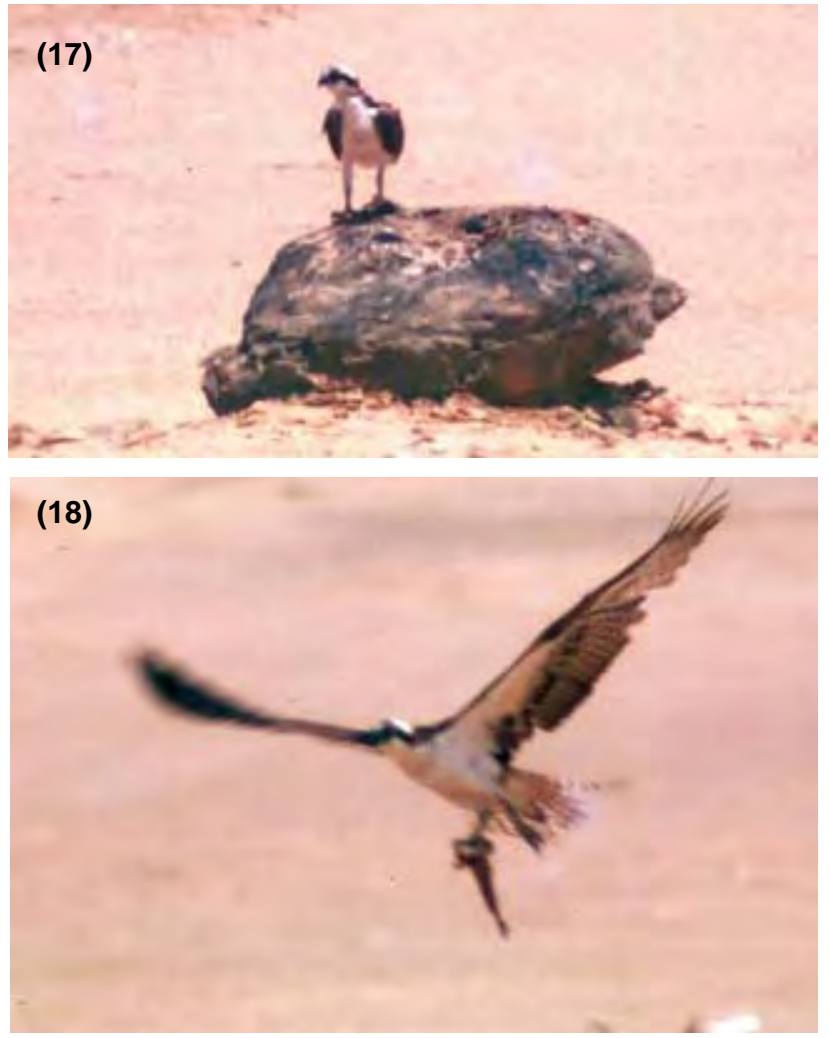

(19)

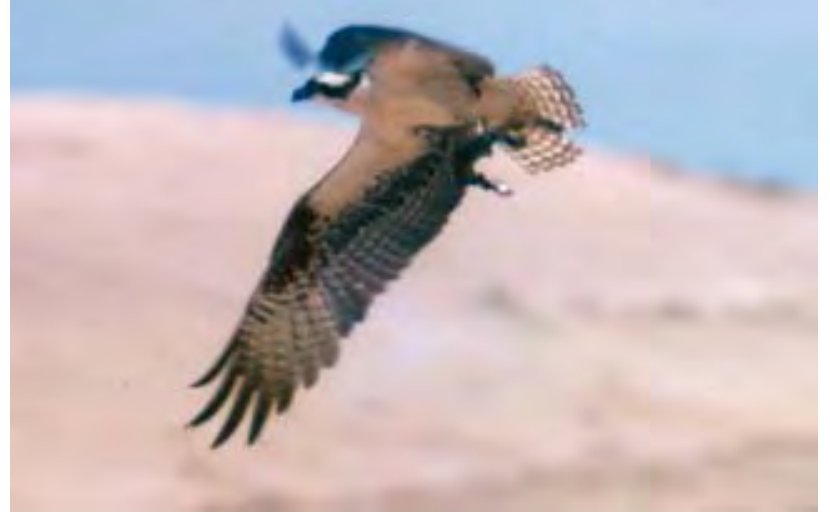

Figure 17-19. Pandion haliaetus with prey.
P. haliaetus emits occ. a high-pitched peeping call.

\section{ACCIPITRIDAE}

\section{Gampsonyx swainsonii}

Jan 1967. Near Jayanca, between Chiclayo and Olmos, Lambayeque: Ind perched on top of a Prosopis pallida.

\section{Chondohierax uncinatus}

12-19/09/1967. Shaim, Rio Marañón, between Chiriaco and mouth of Rio Cenepa, Amazonas, 300 m: 2 inds. daily at a clearing, perched on two bare-branched trees. They communicate for hours, emitting two different calls: an extended hyaaa... and an accelerated kliklikli.

28/02-05/03/1972 Around National Park of Cutervo, Cajamarca:

a) San Andrés de Cutervo, 2200 m: Ind. in flight.

b) At the edge of the N.P., $2400 \mathrm{~m}$ : Ind. - temporary pair - circling over pasture, subsequently perching for a long time on a tree top. Several times it is 'attacked' by a single Pygochelidon cyanoleuca.

c) Between San Andrés and Sócota, 2400 m: Ind. circling over a steep slope.

\section{Circus cinereus}

\section{Sightings}

CP: Junín: Lake Junín, 4100 m; Huancavelica: Pisco Valley, Huaytará, $3600 \mathrm{~m}$.

SP: Ayacucho: Laguna Parinacochas, 3300 m; Apurímac: Laguna Huampica, Hacienda Toxama, north of Andahuaylas, 2700 m; Cusco: Laguna Lucre, $3100 \mathrm{~m}$.

Behavior.- Solitary or in pairs; flies close to the ground with slow wing beats; hovers clumsily.

\section{Accipiter bicolor}

16/02/1964. Amotape Mountains, 800 m, Piura: Ind. in deciduous forest, collected by W. Markl.

\section{Geranospiza caerulescens}

13/01/1966. Zarumilla, Tumbes: Ind. perched on a tree in dense dry forest.

\section{Leucopternis schistaceus}

28/07/1964. Juanjuy, San Martín, 300 m: Ind. perched on a high tree at the edge of a ravine, emitting occ. a shrill call.

\section{Buteogallus anthracinus} forest.

12/01/1966. Puerto Pizarro, Tumbes: Ind. in flight over mangrove

\section{Buteogallus meridionalis}

Sightings.- Coastal plain from Sullana (Piura) to Guadalupe (La Libertad)

Habitat/Behavior.- Dry forest and rice fields; on one occ. together with Larus pipixcan and Bubulcus ibis; more often found on the ground, than perched on trees.

\section{Geranoaetus melanoleucus}

Sightings.- At any altitude from sea level to $4000 \mathrm{~m}$; in NP and $\mathrm{CP}$ mostly on the westslope, also Marañón Valley.

NP: Lambayeque 500 m, Cajamarca 2500-2800 m, La Libertad $2400 / 2800 / 3200 \mathrm{~m}$.

CP: Ancash 0/3000/3500/3700, Pasco 2600 m, Lima 0-3400 m, Ica $1000 \mathrm{~m}$, Huancavelica $3700 \mathrm{~m}$.

SP: Ayacucho 3200 m, Apurímac 3400 m, Cusco 2600-4000 m, Arequipa 3400/3500 m. 
Behavior.- Solitary or in pairs; occ. in small groups of ads. or family groups. Its broad-based wings and short, wedge-shaped tail, which form together a compact triangle, allows it to glide endlessly along slopes with minimal effort. In the lomas, where beetles and crickets abound, it picks up its prey walking on the ground. G. melanoleucus is often harassed by Falco sparverius (6 records). On one occ., an ind. was 'attacked' in flight by three hummingbirds.

12/06/1965. Between San Bartolomé and Zárate, Rímac Valley, Lima $2400 \mathrm{~m}$ : Ind. is perched on a tree, calling continuously. Attracted by its conspecific, another ind. settles on the tree and joins in the calling. It leaves the perch after a short time. The first ind. continues to emit its monotonous call.

27/08/1967. Lomas de Pacta, $45 \mathrm{~km}$ south of Lima, $400 \mathrm{~m}$ : Up to 5 ind. (ads. and immatures) gather on the seasonally green hills. The main attraction seems to be the abounding crickets (Fig. 21/22).

24/08/1969. Lomas de Lachay, $70 \mathrm{~km}$ north of Lima: G. melanoleucus is present all day long (up to 5 inds. simultaneously). They circle
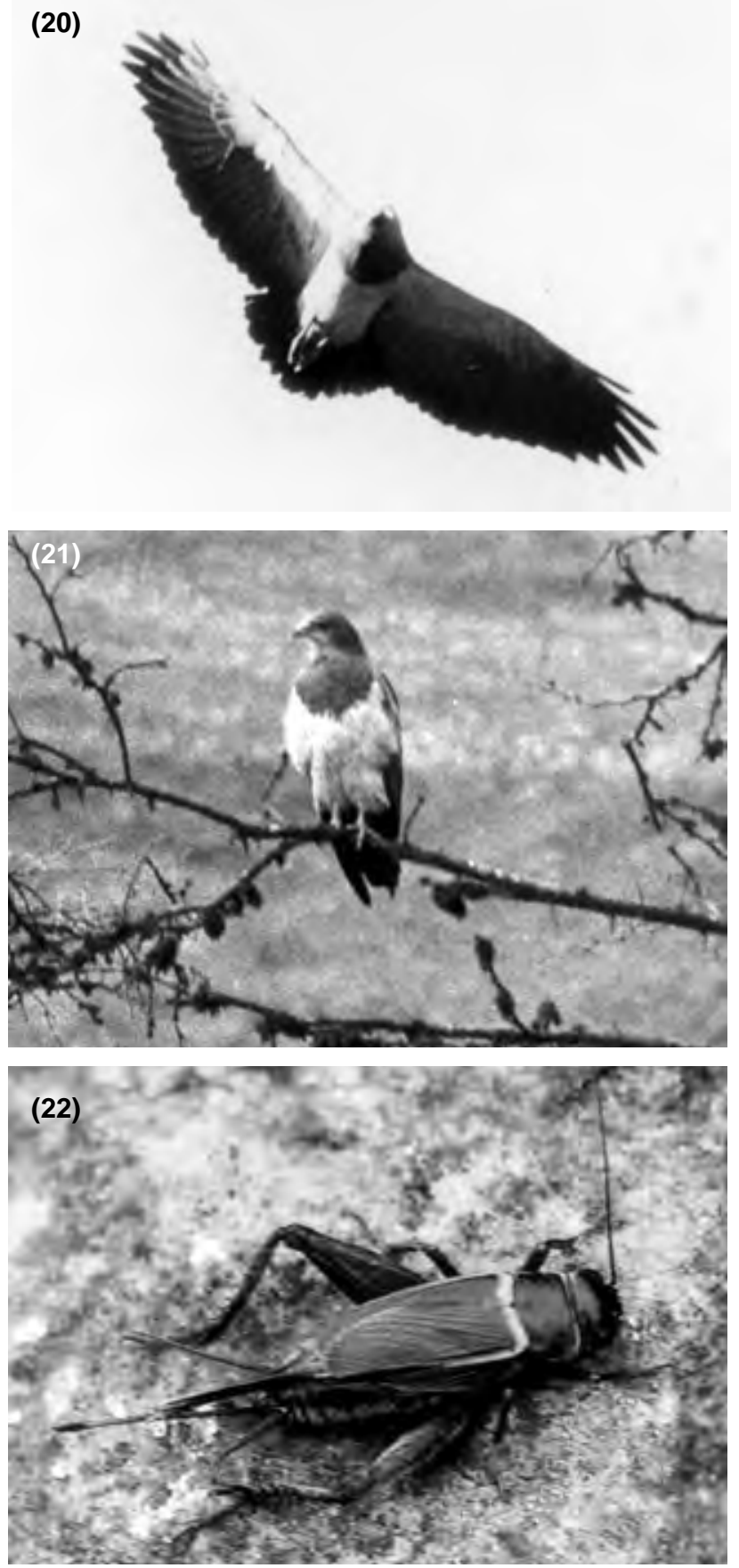

Figure 20-22. (20-21) Geranoaetus melanoleucus. (22) Crickets: abundant prey for $G$. melanoleucus. in the air, perch on trees and boulders or pick up small prey on the ground. - Graceful flight-show (courting?) of two ads.: First, they fly side by side; suddenly, one of them plunges into the depth, immediately followed by its mate. Again, the first makes a sharp turn to one side, the partner follows it instantly. After two or three more playful twists, the two fly for a distance together again. Then the play begins anew. The agility of the rather heavy birds is amazing.

14/07/1988. Colca Valley, Cruz del Cóndor, Arequipa, 3400 m: No condors but a pair of $G$. melanoleucus appear over the canyon. Entering the thermal, they soar incredibly fast. A few moments later they had vanished in the vastness of the sky.

19/07/1988. Paucartambo, Cusco, 3000 m: Roost (or nesting place) in a high cliff over the river. The entrance of the small niche and the cliff below are whitened by droppings.

\section{Parabuteo unicinctus}

08/01/1966. Near Olmos at the road to Bagua, Lambayeque, 600 $\mathrm{m}$ : Immature in deciduous forest perched on a tree.

27/07/1979. Puerto Pizarro, Tumbes: Pair perched on a Bombax tree.

19-21/02/1999. Samaca, Ica Valley, Ica, 200 m: Pair and 2 single inds. on three different days and different times of the day; on each occ. flying upstream.

25/02/2003. Urb. California, Chosica, Lima, 800 m: Ind. perching momentarily on a Eucalyptus tree.

\section{Buteo magnisrostris}

23/01/1970. Watershed between Tingo María and Aguaytía, Huánuco/Ucayali, $1600 \mathrm{~m}$ : One ind. in flight, another perched on the roadside.

04/07/1972. San Ramón, Chanchamayo Valley, Junín, 800 m: Ind.

16/07/1976. Rio Tambopata, Madre de Dios, 250 m: Two single inds. on low perches at river edge.

17/07/1976. Between Quincemil and Marcapata, Cusco, 700-1700 $\mathrm{m}$ : Several records along the road; always singles on low perches; in one occ. in the middle of the road with a prey.

\section{Buteo platypterus}

Boreal migrant

All sightings in Miraflores/Lima, in the months of Nov (1x), Dec $(3 x)$, March $(2 x)$.

06/03/1968. Ind. circling for 5 min over a cotton field

$06 / 03 / 1969$. Ind. soaring slowly over the same field as exactly a year ago!

02/12/1970. Ind. in flight over the Colegio Pestalozzi. Immediatly afterwards, I found a primary of B. platypterus. in the school yard.

$12 / 12 / 1970$. Ind. settles on a tipa tree. Small birds in the neighbourhood are obviously alarmed.

$05 / 11 / 1971$. Ind. at the same place.

17/12/1972. Two ind. circling over the Colegio Markaham. A nervous flock of Pygochelidon cyanoleuca pursues the pair at a respectful distance. Some Columbina cruziana flutter around anxiously, seeking cover in the interior of a group of Eucalyptus trees.

\section{Buteo polyosoma}

Sightings.- (All records apply to the light morph only)

NP: Coastal plain of Tumbes, Piura and Lambayeque; Cajamarca 3500, La Libertad 3300/3400 m.

CP: Ancash 0/3900/4000 m, Lima 0-3500/3900/4800 m, Junín 4100-4400 m, Ica sealevel.

SP: Ayacucho 3900-4200 m, Cusco 3500-3800 m, Puno 3900/4100 m. 
Highest record: Ticlio Pass Lima/Junín, $\mathbf{4 8 0 0 ~ m : ~ I n d . ~ c l o s e ~ t o ~ t h e ~}$ summit.

19/10/1963. North of Chancay, Lima: Immature perches on a sandy elevation $100 \mathrm{~m}$ from the shore. Suddenly, it plunges to the foot of the slope, coming up with a small prey (possibly a lizard). Once returned to the perch, it tears up the prey with a few jerkey movements and swallows it. Afterwards it takes flight and perches in a similar place.

15-16/02/1964. Surroundings of Piura: Fairly common; within a distance of $4 \mathrm{~km}$, we record 6 different inds., one perched on a telephone line, the others ( 3 an 2 inds.) circling over dry scrub with scattered trees. - Between Piura and Sullana: Ind. is gathering sticks and branches on top of a telephone pole. According to W. Markl, it has tried repeatedly to build a nest, but it has been destroyed subsequently by the Telephone Company.

13/06/1965. Zárate, Rímac Valley, Lima: 2 ads. over the ridge above the forest $(\mathrm{ca} .3500 \mathrm{~m})$. Immature circling over the forest $(3000 \mathrm{~m})$. Suddenly it plunges down to a clearing, with its wings folded back and talons stretched out. It returns without prey.

24/07/1965. Between Paramonga and Huarmey, Ancash: Ind. has a short dispute in the air with a Geranoaetus melanoleucus.

29/07/1965. Coina, Chicama Valley, La Libertad, 1600 m: Ind. gliding along scrub-covered slope. Reacts to a harrassing Falco sparverius by trying to avoid the intruder. It interrupts its flight occ. to hover.

06/08/1970. Lomas de Pacta, 45 km south of Lima: Ad. and 2 immatures engage for quite a long time in an acrobatic flight-show: Flying in a close formation, they perform abrubt turns and dives. Short scenes of attack with zig-zag flights alternate with straight passages.

01/03/2003. San Borja/Lima: Ind. circling; first record over urban area of Lima.

\section{FALCONIFORMES \\ FALCONIDAE}

\section{Micrastur ruficollis}

23/03/2003. Posada Amazónica, Rio Tambopata, Madre de Dios: (Location: Observation Tower) Ind. snatches a big-winged insect from a Cecropia-like leaf. It perches on a bare branch and begins to feed on its prey. It calmly tears out small pieces and swallows them. The undigestable wings are discarded. After the meal, it cleans its bill on the branch.

\section{Caracara cheriway}

Sightings.- Coastal plain from Tumbes to northern La Libertad.
Mostly solitary; up to 4 inds. together. When feeding on carrion, often in company of Cathartes aura and Coragyps atratus.

14/02/1964. Near Lambayeque: Ind. settles at the edge of a shallow pond. A group of Larus pipixcan dont take notice of the newcomer.

Jan. 1967. Rio Chamaya, Cajamarca, 900 m: Ind. on a fallow rice field together with numerous Crotophaga sulcirotris.

\section{Phalcoboenus megalopterus}

Sightings.- Throughout the Andes from Amazonas to Puno. Most sightings in the Paramo- and Puna-zone; on both slopes of the Andes; also in intramontane valleys.

Northernmost record: Between Abra Chanchillo and Leimebamba, Amazonas, 3200 m. Lowest record: San Andrés de Cutervo, Cajamarca, $2400 \mathrm{~m}$.

Highest record: Ananea, Puno, $4700 \mathrm{~m}$.

26/06/1965. Laguna Conococha, Ancash, 4050 m: Numerous; in groups of up to 20 inds. at the shore of the lake; about half of them immatures (Fig. 23) When searching for food, they scratch the ground like chickens. - Upper Santa Valley, 3900 m: Ind. perches on the straw roof of a abandoned hut. When it took to the air, the prey was clearly recognizable as a chick.

Mid Jan. 1967. Laguna Yanganuco, Ancash, 3900 m: Young perched on a ledge in a vertical cliff about $100 \mathrm{~m}$ above the ground. It is fed twice by an ad. The approaching ad. anounces itself with kwaad-calls, the young responds with squeaky sounds, that are reminiscent of a young pig.

18/02/1967. Machu Picchu, Cusco, 2700 m: Pair in flight, both calling all the time without interruption: kwaak'kwaa...

06/07/1993. Between Chugay and Aricapampa, La Libertad, 3500 $\mathrm{m}$ : Pair in straight flight high over the Paramo, calling incessantly.

15/03/2003. Between Juliaca and Abra La Raya, Puno, 3800-4300 $\mathrm{m}$ : Fairly common; they like to perch on the telephone poles along the road.

\section{Falco sparverius}

Behavior.- Hovers frequently; in updraught winds uses 'hanging hover'. Aggressive attitude towards other birds of prey and owls. Recorded attacks: Geranoaetus melanoleucus (4x), Buteo polyosoma (2x), Falco femoralis (1x), Bubo virginianus $(1 \mathrm{x})$. When pursuing an 'enemy' in flight, it approaches it from above and behind passing close over its head. It may pursue it over a long distance, persistently repeating the attacks. The attacked bird may be annoyed but obviously does not feel

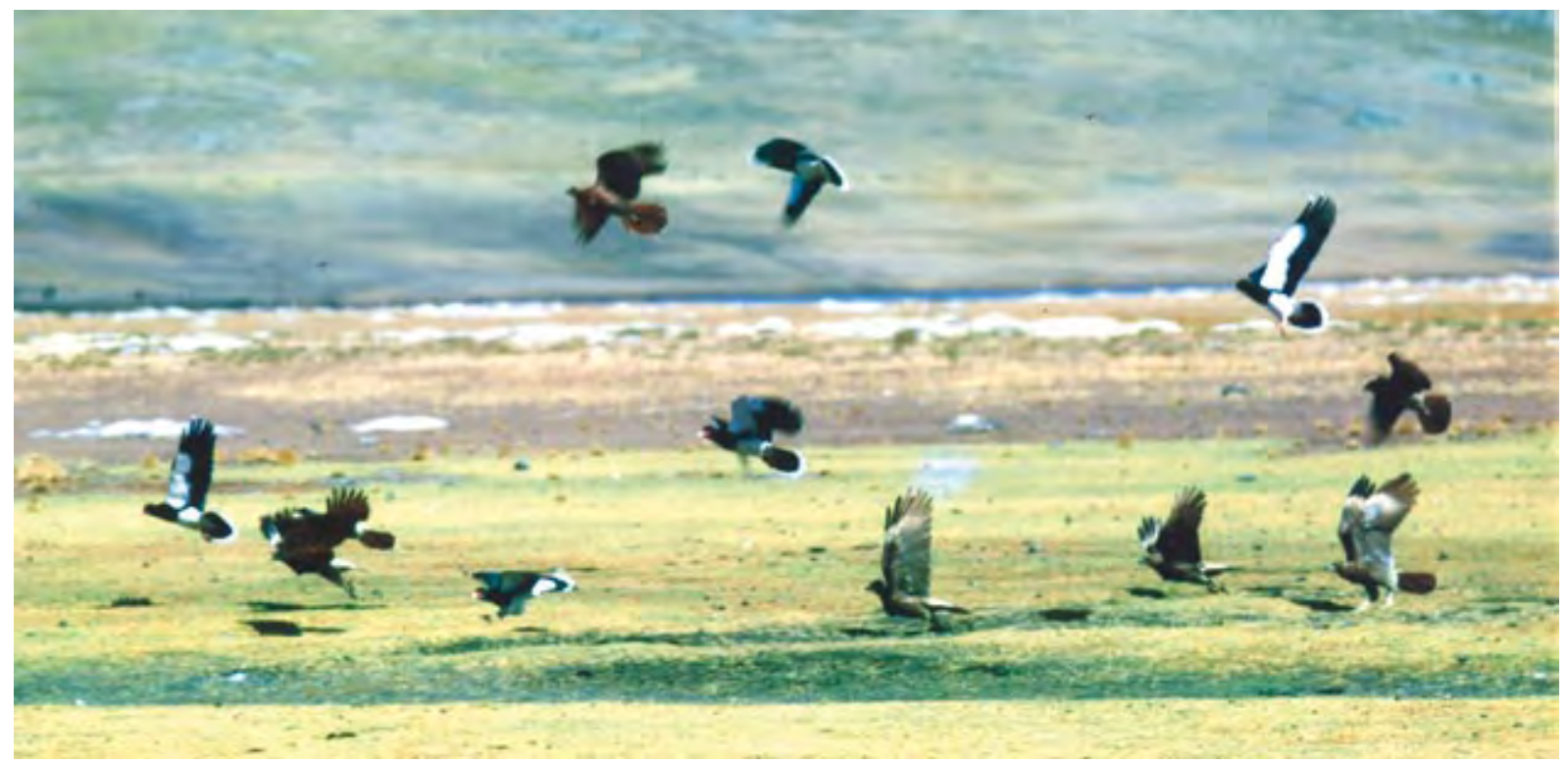

Figure 23. Phalcoboenus megalopterus: adults and immatures. 
menaced. Even so, F. sparverius occ. succeeds in expelling the much larger birds from its territory.

29/02/1964. Viscas, Mala Valley, Lima, 1800 m: 3 inds. are attracted by a Bubo virginianus, sitting in a niche of a cliff at the edge of a dry quebrada. They harrass it incessantly by passing near the niche as close as possible, emitting their sharp killy'killy'killy-calls. The only reaction of the big owl: It shuts its eyes whenever the intruders pass.

02-07/02/1965. Casta, Santa Eulalia Valley, Lima, 3100 m: Ind. lingers daily in the same habitat: pasture, small fields, hedges and scrub. Perches preferably on a $3 \mathrm{~m}$ high pole, where it also feeds on its prey.

15/05/1965. Orcocoto, Lurin Valley, Lima, 1800 m: Ind. shoots forth from beneath the roof of a church. Judging from the white markings on the wall and the underside (!) of the roof, it just left its nesting site.

29/07/1965. Chicama Valley, La Libertad, 1800 m: 4 inds. (2 ads. and 2 young) linger on a high, inaccessible boulder. The older young besieges the ad. by emitting begging calls. One of the young eventually climbs about in the vegetation (e.g. Bromeliaceae), that covers the cliff.

28/04/1967. Autisha, Santa Eulalia Valley, Lima, 2200 m: Mating act in the middle of the road; female crouched with spread out tail.

28/09/1970. Pullo near Laguna Parinacochas, Ayacucho, 3000 m: A boy shows us two downy-white young, that he had taken from their nest in a building of the village.

01-08/09/1972. Casta, Santa Eulalia Valley, Lima. 3100 m: Pair perching daily on a pole or on the cable of a newly constructed powerline. Their main prey are insects (crickets abound). They softly glide to the ground, grab the prey with their bill, carry it back to the perch, fix them with one foot and consume it in 3-4 bits.

\section{Falco femoralis}

\section{Sightings}

NP: Cajamarca $3500 \mathrm{~m}$

CP: Ancash 3900 m, Junín 4000-4400 m, Lima 3700-4000 m

SP: Ayacucho 3400 m, Arequipa 4000/4300 m, Puno 3900 m

Behavior.- Perches low on stones, boulders and poles; also on the ground. Solitary or in pairs; occ. 3 inds. together. Pursuit flight low over the ground. Likes to perch on a boulder when the sun rises with fluffed plumage and hanging wings, its back turned towards the sun.

01/10/1970. Laguna Parinacochas, Ayacucho, 3400 m: Ind. perches on the edge of a cliff, warming up in the morning sun. It is harrassed by Falco sparverius and subsequently by Colaptes rupicola. After several attacks, the latter settles only a few meters away from F. femoralis

\section{Falco peregrinus}

Boreal migrant

Sightings.- Coast from Tumbes to Ica; 15 records (of a otal of about 35) in the urban areas of Miraflores/Lima and San Isidro/Lima. Main season: Nov-Feb (25 records); also in Oct (2), Mar (4), Apr (1). Earlyest record: 18.10.; latest record 13.4.

06/01/1964. Mouth of Rio Virú, La Libertad: Ind. in the morning mist, perching on a piece of driftwood at the beach. There are fresh footprints in the sand and leftovers of a meal: Fresh ones of Larus pipixcan (Fig. 24) and older ones of Sterna spec.

09/01/1966. Between Los Organos and Máncora, Tumbes: Ind. pursuing for a short time Coragyps atratus.

20/11/1967. San Antonio, Miraflores/Lima: The behavior of certain birds indicates the presence of $F$. peregrinus: Uncommon calls of alarm and an upset domestic dove in zigzag-flight. Moments later the feared hunter appears with fast wing beats over the residential area.

Feb 1969. South of Paracas, Ica: Ind. hunting over Laguna Grande. It steep dives in pursuit of a Sterna spec., which manages to escape several times by zigzaging low over the water. Occ. F. peregrinus is very close to its prey. After 2 or $3 \mathrm{~min}$, the pursuer gives up.

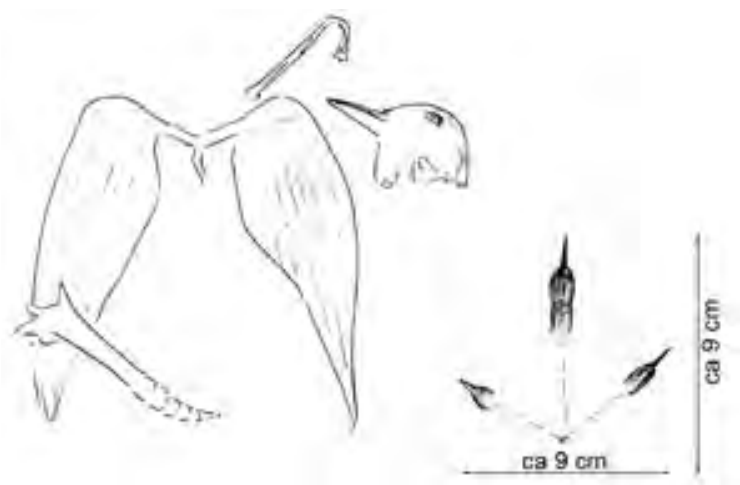

Figure 24. Falco peregrinus: remains of Larus pipixcan; footprint.

09/03/1969. La Molina/Lima: Agricutural area: Cornfield with young plants bordered by long rows of mighty willows. An ind. steep dives onto the field almost touching the ground. Reason: There is an injured Zenaidura auriculata (which the falcon had failed to grab in the air earlier) anxiously jittering about. F. peregrinus repeats its attacks several times, starting at a considerable height. It always fails to grab the dove. Finally, I picked up the injured bird (it survived).

\section{GRUIFORMES \\ RALLIDAE}

\section{Laterallus jamaicensis}

07/02/1964. Lagunas de Chilca, 65 km south of Lima: Ind. flushed at the edge of a lagoon; it flies poorly and goes immediately into hiding in the totora thicket.

\section{Pardirallus sanguinolentus}

\author{
Sightings \\ NP: La Libertad sealevel \\ CP: Junín 3400, Lima 0-800/1600/1700/3200/3500 m, Ica 300 m \\ SP: Cusco 3600 m, Arequipa 2600 m, Puno 3800 m
}

Habitat.- Marshland, lagoons, totorales, river edges with dense vegetation, irrigation channels, and fields.

Behavior.- Solitary or in pairs; at favorable places (e.g. Laguna de Villa, mouth of Rio Mala) quite numerous. In general very shy; it does not venture far from cover. When alarmed, raises tail and bobs with head; prefers to run rather than to fly. Forages at any time of the day, but preferably at dawn and dusk.

13/02/1970. Laguna Orovilca, Ica, $300 \mathrm{~m}$ : Ind. foraging at the edge of the totoral, a small oasis in the middle of high sand dunes. Distance to the nearest irrigated field about $5 \mathrm{~km}$.

06/07/1972. Laguna Paca near Jauja, Junín, 3400 m: Ind. at the edge of the large lagoon. The shallow water is covered with a carpet of aquatic plants, thick enough for $P$. sanguinolentus to walk on it. While foraging, it comes across a carcass of a small bird. With its long bill it tears off tiny bits and swallows them. Alarmed, it carries its prey into the nearby thicket.

18/07/1988. Lagoon near Chincheros, Cusco, 3600 m: Quite numerous at the longstretched lagoon, with extended totora thicket. Wading in the shallow water up to their bellies in search of food, they poke avidly in the rich floating vegetation.

\section{Gallinula chloropus}

\section{Sightings}

Coast: Piura, La Libertad, Lima, Ica

Andes: Cajamarca, Junín, Cusco, Puno

Northernmost record in the Andes: Rio Crisnejos, between Cajabamba and San Marcos, probably below $2000 \mathrm{~m}$. 
Behavior.- Gregarious; in pairs or groups of different size (e.g. Laguna Villa 50-60 ind.); in very large numbers at Lago de Junín, Laguna Lucre (Cusco) and at a lagoon near Piura. Feeds swimming or walking on mudflats and in marshland.

27/11/1963. Lagunas de Chilca, $65 \mathrm{~km}$ south of Lima: Present on many of the small lagoons. On one occ. a down-clad young disappears with their parents in totora thicket.

\section{7/02/1964. Same place: Juv.}

25/08/1968. San Juan de Miraflores, south of Lima: Several ind. on and at a large waste water lagoon in plain desert, that was created a year ago. They probably immigrated from Villa, about $3 \mathrm{~km}$ away.

13/02/1970. Laguna Orovilca, Ica, $300 \mathrm{~m}$ : Ind. on one of the three tiny lagoons, surrounded by high dunes. Distance to the next agricultural fields about $5 \mathrm{~km}$.

16/09/1972. Puerto Viejo, $70 \mathrm{~km}$ south of Lima: Numerous; ind. stalking with raised tail, outer tail feathers spread-out.

\section{8/07/1976. Mouth of Rio Virú, La Libertad: Juv.}

28/07/1988. Near Chincheros, Cusco, 3600 m: Numerous on an extended lagoon. Family with 3 dark grey, downy young. Ad. adopts menacing posture raising its white tail feathers.

17/02/1999. Laguna de Huacachina, Ica, 300 m: Several inds.; they dispose of only a small patch of totora as a refuge and breeding site.

\section{Fulica ardesiaca}

18/07/1988. Near Chincheros, Cusco, 3600 m: Quite numerous on a longstretched, partly covered by totora lagoon. Two pairs with 3 young each: upperparts light grey, underparts whitish, bill blackish. When foraging, they submerge their bill only slightly. While moving forward, they pick up water weed and throw it away by swinging their head from one side to the other. The young try to imitate the ads. Once in a while, they approach the ads. in order to beg for food, snatching it from their bill.

\section{Fulica gigantea}

Sightings.- Ancash 4000-4200 m, Lima 4300 m, Junín 4200 m, Puno $4000 \mathrm{~m}$

26/06/1965. Laguna Conococha, Ancash, 4050 m: Numerous; solitary, in pairs or loose flocks in company with Chloephaga melanoptera. Many of them are grazing on the lawn-like vegetation at the lake side. Pair with $\mathbf{2}$ young is foraging on the lake.

10/04/2003. Upper Santa Valley, Laguna Patacocha, Ancash, 4200 $\mathrm{m}: 17$ inds. at the shallow lagoon, which measures about $100 \times 200$ $\mathrm{m}$ and is largely covered with aquatic plants (mostly Myophyllum). F. gigantea and Lophonetta specularoides leave behind a net of narrow 'trails' on the thick green carpet. Out of 7 'nesting-islands' 3 or 4 are occupied by breeding ads. The nests consist of randomly piled up water weed. They measure about one meter at the base and rise $20-30 \mathrm{~cm}$ above the water. Calls: Growling and chortling sounds.

\section{HELIORNITHIDAE}

\section{Heliornis fulica}

13/01/1965. San Ango, oxbow lake south of Yurimaguas, San Martin, $200 \mathrm{~m}$ : Swimming ind. pecking at plants at the flooded edge of the lake.

\section{EuRYPygIDAE}

\section{Eurypyga helias}

16/07/1976. Lower Rio Tambo, Madre de Dios, 250 m: Ind. at the sandy shore.

\section{CHARADRIIFORMES \\ CHARADRIIDAE}

\section{Vanellus resplendens}

Sightings.- Throughout the Andes from Amazonas (lowest record $2400 \mathrm{~m}$ ) to Puno (highest record $4800 \mathrm{~m}$ ); most frequently in the Puna zone around $4000 \mathrm{~m}$.
One record from the coast: Lagoon between San Juan and Villa, south of Lima: Pair together with numerous shore birds (17.08.69).

Behavior.- Solitary, in pairs or loose flocks, sometimes in very large numbers (Lago de Junín, Laguna Parinacochas).

19/04/1964. Marcahuasi, Santa Eulalia Valley, Lima, 3900 m: Numerous on the rocky plateau with humid flats and dispersed small lagoons, forming groups of up to 10 inds. When approached, they fly low over our heads, emitting angry screams. - Single ind. perched on a boulder seems to act as a guard .

10/04/2003. Upper Santa Valley, Laguna Patacocha, Ancash, 4100 $\mathrm{m}$ : Flock of 20-30 inds. performs graceful flight shows while screaming persistently. After some turns over the lagoon, they pause, starting anew after a short time.

\section{Charadrius semipalmatus}

Boreal migrant

Sightings.- Along the coast from La Libertad to Ica; regularly and most numerous at the Peninsula of Paracas; from July to March (highest frequency in Feb); earliest record 09.07. Paracas, Ica; latest record 11/03. Villa, Lima

Behavior.- In loose groups (on the ground) or close flocks (in flight); 10-40 inds. often together with other shore birds. Forages on mudflats, wetland and at river mouths. Rests on reefs and sledges. Performs graceful flight shows. On one occ. a large flock suddenly splits up as if on command into three groups.

\section{Charadrius wilsonia}

26/07/1979. Puerto Pizarro, Tumbes: Common on beach and mudflat. Pair - probably breeding - on a long sand bank tries to attract my attention. When I stand still, it scurries around me. One of them adopts a crouched position. When I approach it, it gets up with hanging wings, performing some helpless hops. Then it flies for a short distance, just to start the ploy again.

\section{Charadrius vociferus}

Regularly in small groups of 2-6 inds. in flight over the urban areas of La Victoria/Lima and Miraflores/Lima. Their characteristic call can be heard at any time of the day. They pass by, circle or wander about aimlessly for up to half an hour. Nocturnal calls: Numerous records from Feb to Oct, e.g. "First half of March 67: Calling in flight almost every night, beginning at 18:30/19:00". No night records from Nov to Feb.

At the following sites, conspicuous behavior and anxious calls suggests breeding activity: 22/11/1966 - 18/11/1967 Lagoon between San Juan and Villa, south of Lima; 01/08/1976 Mouth of Rio Virú, La Libertad.

\section{Charadrius alexandrinus}

From the mouth of Rio Jequetepeque, La Libertad to Chala, Arequipa. Mostly in pairs or small groups of up to 8 ind. Often together with other shore birds.

19/11/1967. Playa Chira, south of Lima: Clutch of 2 eggs about $100 \mathrm{~m}$ from the shore. The shallow scrape is lined out with small pieces of shells and bordered with some large, rather casually arranged bird bones (Fig. 25/26). Eggs: a light turquoise with numerous black and a few grey dots; $23 \times 34 / 22 \times 31 \mathrm{~mm}$.

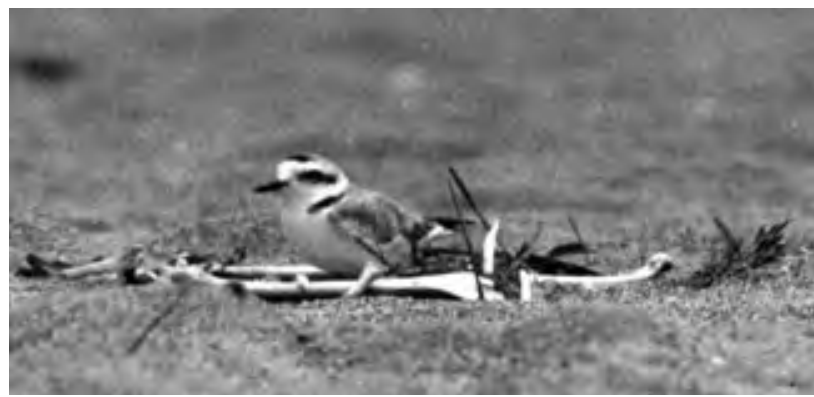

Figure 25. Charadrius alexandrinus at breeding site. 


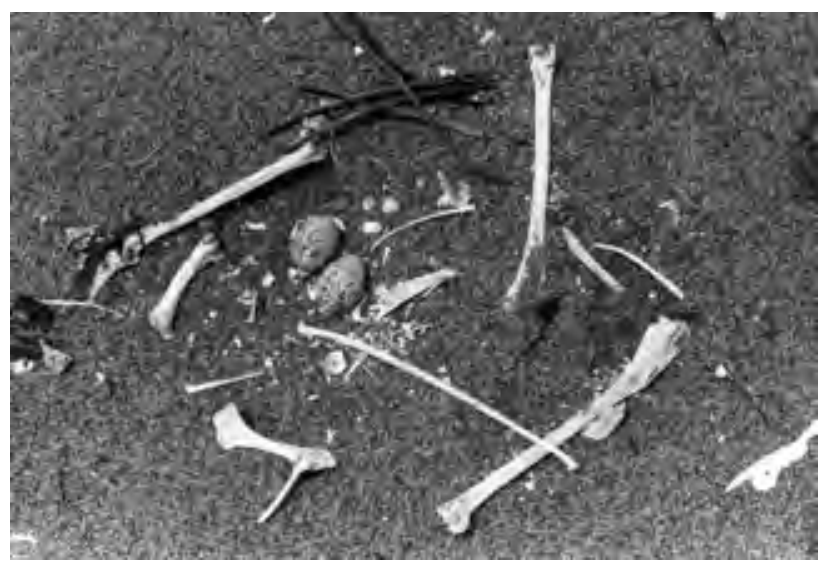

Figure 26. Clutch of Charadrius alexandrinus.

29/12/1967. Puerto Viejo, $70 \mathrm{~km}$ south of Lima: Quite numerous at the shore, mostly solitary or in pairs. Two young in different stages of development: No. 1 is a sand colored downy ball with speckles; its wings measure $2-3 \mathrm{~cm}$. It is amazingly fast on the run. No. 2 (not related to No. 1) is more developed. It tries to escape with a zig-zag run, spreading its $7-8 \mathrm{~cm}$ long wings to maintain the balance.

\section{Oreopholus ruficollis}

27/08/1967. Lomas de Pacta. $45 \mathrm{~km}$ south of Lima: Loose group of about 10 ind. at the foot of the lomas; not shy (Fig. 27).

24/08/1969. Lomas de Lachay, $70 \mathrm{~km}$ north of Lima: Ind. at the sandy foothill.

29/09/1970. Laguna Parinacochas, Ayacucho, 3300 m: Very numerous on a plain near Incahuasi. They do not form a close flock; each ind. stays some meters apart from its neighbours. When alarmed, they pause in a typically upright position.

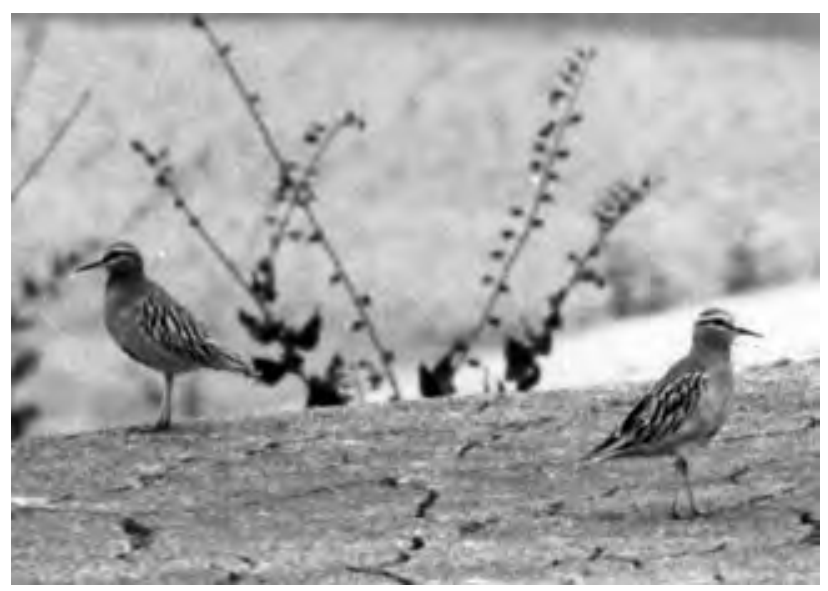

Figure 27. Oreopholus ruficollis.

\section{HaEmATOPodidAe}

\section{Haematopus palliatus}

Sighted from Tumbes to Arequipa; regularly at the Peninsula of Paracas; solitary, in pairs or small groups of up to 10 ind. Feeding on sandy beaches, resting on dry ground not far from the shore.

11-17/02/1969. Playa Vineta, south of Paracas, Ica: Often in pairs or small groups along the beach; a total of 30-50 inds. at a length of several kilometers. When I approach a group, it withdraws inland, then suddenly stops. The birds almost 'disappear', thanks to their body pattern. When flushed, they take to the air, emitting their alarm call: kip-kip-ki'kiki'kip.

\section{Haematopus ater}

Recorded along the coast from Ancash to Ica; mostly in pairs; on reefs or rocky promontories, but often feeding on the adjacent beaches, attracted by Emerita.
Two ind. (different place, different date) with the same injurie: All three toes of one foot are missing. They seem to be only slightly disabled.

31/01/1999. Playa Grande, Panamericana Norte, km 340, Ancash: Up to 6 inds. on a flooded ledge with rich food supply.

\section{RECURVIROSTRIDAE}

\section{Himantopus mexicanus}

Sighted at coastal area of Tumbes, Piura, Lambayeque and Ancash on mudflats, wetlands, ricefields and inundated fallow land; mostly in small, occ. in large groups (about 50 near Santa Rosa, Lambayeque; about 100 near Puerto Casma, Ancash)

\section{BURHINIDAE}

\section{Burhinus superciliaris}

15/08/1967. Limatambo/Lima: Ind. on partly asphalted waste land (ancient airport); runs fast, flies reluctantly (Fig. 28).

19/04/1969. La Molina/Lima: Pair on a sandy plain at the edge of agricultural fields; stuttering call, when taking to the air.

01/10/1970. Near Chala, Arequipa: Pair at the side of the road to Cháparra in the sand desert.

17-21/02/1999. Samaca, Rio Ica, 200 m: Occ. nocturnal calls. Numerous foot prints on the sandy or muddy ground along the river between patches of Tessaria and Prosopis.

21/02/2003. Batán Grande, Bosque de Poma, Lambayeque: Numerous foot prints at the muddy shore of Rio Leche.

\section{ScolopacidaE}

\section{Numenius phaeopus}

Boreal migrant

Sighted from Tumbes to Tacna; from July to Apr, with no evident peak. Earliest record 07.07. Cañete, Lima; latest record 05.04. Puerto Viejo, Lima. Mostly on sandy beaches, occ. on pastures or wetland not far from the shore: solitary or in small groups, also forming large flocks of 30, 50 or up to 100 ind. They associate easily with other shore birds. When flushed, they take refuge on reefs or rocky promontories.

24/09/1963. San Roque, Surco/Lima: Long stretched flock on their way south settles in groups of 3 or 4 inds. in pasture with tall grass.

31/08/1968. Miraflores/Lima: Close flock of 16 inds. flying southward over a cotton field, calling incessantly wee'wee'wee...The position of each ind. within the group changes during flight: Inds. at

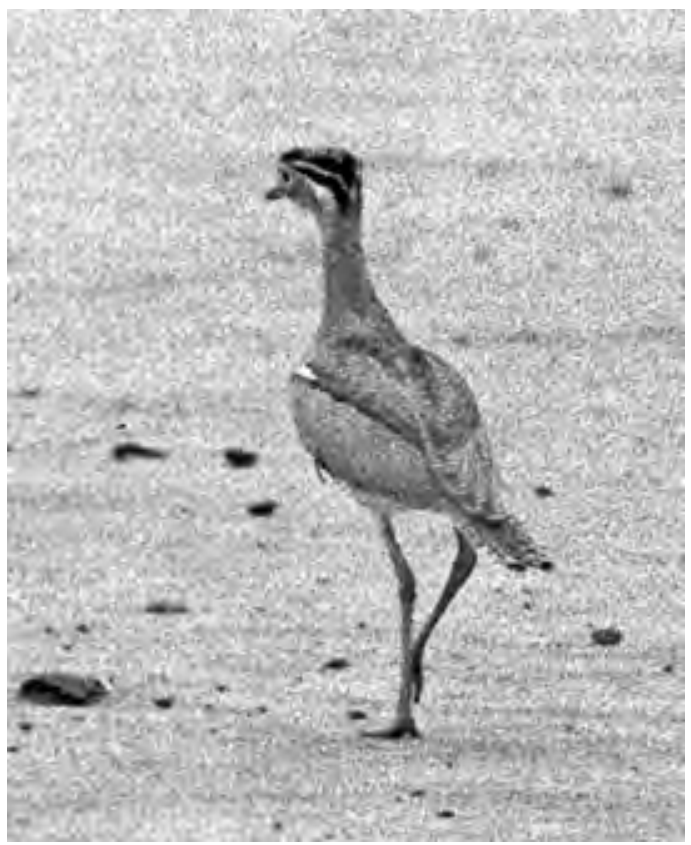

Figure 28. Burhinus superciliaris. 
the front, slow down, turning up at the rear and those from the rear advance to the front.

11-17/02/1969. Between Paracas and Laguna Grande, Ica: Numerous; mostly in loose groups of up to 30 inds. on different beaches. They roost in close flocks on rocky shore or on reefs. When flushed, their standard call gets high pitched with a crescendo.

01/02/1972. Mouth of Rio Sama, Tacna: About 100 ind.; 4 of them are bathing in the shallow lagoon at the river mouth. They dip their heads into the water and throw it backward in an elegant sweep. Occ. they crouch, with hanging wings, belly and breast submerged.

\section{Bartramia longicauda}

\section{Boreal migrant}

09/03/1971. Mouth of Rio Mala, Lima: About a dozen inds. on a pebble-strewn area apart from the river.

\section{Actitis macularius}

\section{Boreal migrant}

Sighted from Tumbes to Ica on mudflats, beaches, along rivers and irrigation channels and on river mouths; lower reaches of coastal valleys of Lima.

East of the Andes recorded along rivers in San Martín, Ucayaly, Huánuco and Pasco.

Recorded from July to April; peak in Jan; earliest record 27.07. Puerto Pizarro, Tumbes; latest record 11.04. mouth of Rio Chillón, Lima. In April, Aug and Sep some inds. in alternate plumage.

Highest records: Santa Eulalia Valley, Lima 1800 m; Lurin Valley, Lima, 1800 m; Rio Paucartambo, Pasco 2600 m: Several inds. during three days regularly along the stream.

\section{Tringa melanoleuca}

\section{Boreal migrant}

Most sightings along the coast, frequently around Lima; also in the region of Lake Titicaca. Number of monthly records: Jan 8x, March 2x, Aug 3x, Nov 1x; earliest record 01/08. mouth of Rio Virú, La Libertad; latest record 09/03. mouth of Rio Mala, Lima.

11/03/1964. Totoral de Villa, south of Lima: Mixed group of $T$. melanoleuca and Tringa flavipes of about 40 inds.; some foraging at the mudflat and in shallow water, some tiding up or bathing, the rest sleeping with heads buried in their plumage.

25/08/1968. San Juan de Miraflores, south of Lima: Numerous on newly created waste water lagoons in plain desert, together with $T$. flavipes, Larus cirrocephalus, Ardea alba and Egretta thula.

05/08/1983. Mouth of Rio Mala, Lima: Mixed group of T. melanoleuca and T. flavipes of 80-100 inds. feeding in shallow water and adjacent mudflat.

\section{Tringa flavipes}

Boreal migrant

Most sightings at the coast of Lima; also one in Puno and one in La Libertad (mouth of Rio Virú). Recorded in Jan, Mar, Apr, Aug, Nov.

Particular records see Tringa melanoleuca.

\section{Tringa semipalmatus}

Boreal migrant

11/01/1966. Puerto Pizarro, Tumbes: 2 inds, one feeding on mudflat, the other in flight together with 4 Numenius phaeopus.

29/12/1967. Puerto Viejo, $70 \mathrm{~km}$ south of Lima: Ind. at the beach together with 60 Numenius phaeopus.

30/09/1971. Mouth of Rio Jequetepeque, La Libertad: Ind.

05/08/1983. Playa Conchán, south of Lima: 2 inds.

\section{Arenaria interpres}

Boreal migrant

Recorded from Lambayeque to Arequipa; on rocky as well as on sandy shores. Groups of 10-30 inds.; may form large associations. Sighted from Aug to Apr; peak in Feb. Earliest record 01.08. mouth of Rio Virú, La Libertad; latest record 30.04. San Bartolo, Lima.

27/11/1983. Between Chilca and Mala, $80 \mathrm{~km}$ south of Lima: Several groups of 8-12 inds. feeding on small reefs near the shore. They scrutinize the countless holes and crevices of the periodically flooded rocks. On two occ. a group is expelled from its hunting ground by a single Cinclodes taczanowski, which is defending its territory.

16/09/1972. Puerto Viejo, $70 \mathrm{~km}$ south of Lima: 3 inds. are feeding on abundant crab carcasses. They push their bill beneath a crab shell, turn it forward, grab the edible content and swallow it hastily. The three birds are eagerly at work, whirling around the dry remains of the crabs.

\section{Aphriza virgata}

Boreal migrant

10/01/1964. Pimentel, Lambayeque: Small group at the beach.

21/02/1964. Paracas, Ica: 2 inds., one bearing the basic, the other one the alternate plumage; they forage on a rock within the tidal zone.

01/04/1964. Puerto Viejo, $70 \mathrm{~km}$ south of Lima: Numerous on the beach and on nearby reefs in company of Numenius phaeopus. (4 days later, A. virgata is absent)

12/09/1965. Callao/Lima: Numerous along the mole of the yacht port.

15/09/1965. Morro Solar, Chorrillos/Lima: Scattered ind. at rocky shore.

$22+24 / 02 / 1966$. Lagunillas, south of Paracas, Ica: Flock of 30-40 inds. on a small reef.

13/02/1970. Same place: Large group.

\section{Calidris alba}

Boreal migrant

Recorded along Coast from Lambayeque to Ica; from July to Apr.; peak in Sep; earliest record 09/07. Paracas, Ica; latest record 11/04. mouth of Rio Chillón, Lima.

Often forming large groups of 100 or more inds.; associates with other shore birds. C. alba can be found competing with Larus modestus for food or defending its prey when attacked. The sight of hundreds of C. alba running for food with the rhythm of the waves is impressive. When the waves ebb, the little birds turn around instantly, briefly taking advantage of the exposed prey. When the wave surges again, they run in the opposite direction. At some distance it looks like a flowing carpet, moving forward and backward in perfect accordance with the sea.

\section{Phaloropus tricolor}

Boreal migrant

\section{Sightings}

Coast: La Libertad, Ancash, Lima, Ica

Andes: Aycucho 3300 m, Puno 3800 m

Out of 13 sightings 3 ocurred in Aug, 7 in Sep, 1 in Oct, 1 Jan, $1 \mathrm{March}$; mostly on small, nearshore lagoons; normally 1-4 inds.; occ. in larger numbers. Typical feeding display: While spinning around as if sitting on a disc player, $P h$. tricolor collects hastily the small prey, that it has flushed to the surface.

\section{THINOCORIDAE}

\section{Attagis gayi}

10/04/2003. Upper Santa Valley, Ancash, ca. 4000 m: Pair in open Puna landscape; one of them goes into hiding, the other continues picking seeds at the road side. They communicate with a soft whisper. 


\section{Thinocorus orbignyianus}

\section{Sightings}

NP: Cajamarca $3500 \mathrm{~m}$.

CP: Lima 3900 m, Junín 4100-4300m.

SP: Ayacucho $3400 / 3500 \mathrm{~m}$, Cusco 4500m, Arequipa $4200 \mathrm{~m}$, Puno $4000 \mathrm{~m}$.

19/04/1964. Marcahuasi, Santa Eulalia Valley, Lima, 3900 m: Small groups on rocky plateau; one fledgling.

02/05/1964. Near Corpacancha, Junín, 4200 m: Pair with fledgling in Puna grassland.

\section{Thinocorus rumicivorus}

19/10/1963 / 11/09/1965 / 22/09/1967 / 24/08/1969. Lomas de Lachay, $70 \mathrm{~km}$ north of Lima: Numerous; courting activity; flight display: the ascent is followed by an even, curved descent. Song given during flight display: $t$ Ogara'tOgara ...; call on the ground: wot'wot...

28/01/1970. Divide between Canta Valley and Chancay Valley (Trapiche-Huayán), Lima, 1500 m : Several voice records. The normally barren hills are covered with lush vegetation due to extraordinary rainfalls.

\section{STERCORARIIDAE}

\section{Stercorarius chilensis}

Austral migrant

12/09/1965. Between Callao and Isla San Lorenzo, Lima: Several sightings of 1-3 inds. on a boat trip.

\section{LARIDAE}

\section{Creagrus forcatus}

Boreal migrant

08/09/1988. Bay of Paracas, Ica: 10-15 inds. swimming about 500 $\mathrm{m}$ from the shore; most of them in basic plumage.

\section{Leucophaeus modestus}

23/06/1972. Playa Chira, south of Lima: At 6 pm about 500 inds. have gathered on a sandy plain about $100 \mathrm{~m}$ from the beach, probably a roosting place. There is a busy coming and going. 8 dispersed inds. of Leucophaeus dominicanus form part of the congregation. - A L. modestus arrives at the beach with a prey, that it has caught offshore: a bright coloured, blue and brown-orange crab. It lays the crab on the ground, grabs it, shakes it strongly, drops it again. After repeating the procedure several times, it manages - without use of the feet - to tear out piece after piece of the crab meat. Afterward it goes about grabbing the empty shell holding it up in a 'drinking' position. It drops, grabs and holds it up again. Finally it carries the shell about $20 \mathrm{~m}$ out to the sea. There, the gull continues to play, laying the relic of its meal on the surface of the water like a bowl. When it sinks, the bird retrieves it by submerging its head. After some repetitions, it gives up and withdraws.

\section{Leucophaeus pipixcan}

\section{Boreal migrant}

Sightings.- Coast from Tumbes to Tacna; coastal valleys of Lima: Rímac Valley up to $800 \mathrm{~m}$; Canta Valley one record at $1500 \mathrm{~m}$. The first flocks arrive at the beginning of Nov, the last ones depart at the end of Apr; one record in Oct (09/10, Pimentel, Lambayeque); one at the beginning of May (Conchán, Lima)

Habitat/Behavior.- Most numerous at sand beaches and river mouths, where they congregate by the thousands. They occ. take advantage of an upcurrent over the coastal plain, forming a kind of tube or whirl up to a hundred meters high. They disperse after some time and eventually reform at another adequate place.

05-08/02/1964. Playa León Dormido, Panamericana Sur, km 90: Daily 1000-1500 inds. at the $1200 \mathrm{~m}$ long beach. They appear at dawn and disappear at dusk, probably to roost somewehre inland. During the day, they rest on the sand within the dry area of the beach or they swim outside the surge.

27/12/1965. Playa Conchán, south of Lima: Thousands on their migration to the south: From 14:30 to 16:00 large flocks pass by in short intervals in chain or delta formation. Next day, same place, same time: The migration continues, but is less intense.

01/11/1972. Playa León Dormido: Flying southward in large numbers from 12:00 to 15:00 in flocks of 100-300 inds. constantly changing their formation: from orderless clusters to chain- or delta-formations (Fig. 30). The largest delta-formation counts 80 inds. on each 'wing'. Flight altitude: $20-150 \mathrm{~m}$. Only one ind. touches for an instant the beach: to snatch away an Emerita from a startled Leucophaeus modestus.

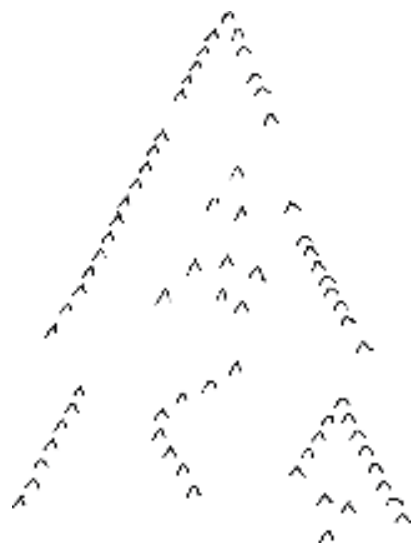

Figure 30. Flight formation of Leucophaeus pipixcan

29-30/04/1972. Playa Conchán, south of Lima: Very numerous; probably on their way north. The mass mortality of seabirds in 1972 seems also to have affected L. pipixcan: Among 227 dead birds there are 9 carcasses of L. pipixcan. An unidentified scavenger has left of them only bare bones and plumes. The other species have been left untouched.

\section{Chroicocephalus serranus}

\section{Sightings}

NP: Cajamarca 3500 m, La Libertad 2300 m.

CP: Ancash 4000 m, Junín 3800-4800 m, Lima 4200-4700 m, coast of Ica.

SP: Ayacucho 3300 m, Apurímac $\mathbf{2 8 0 0}$ m, Cusco 3000-3400 m, Puno $3800-4300 \mathrm{~m}$, Arequipa $4200 \mathrm{~m}$.

Min. alt: Rio Chusgón, La Libertad, 2300 m; max. alt. Ticlio Pass, Lima/Junín, $4800 \mathrm{~m}$.

28-29/11/1964. Huaura Valley, Lima, 4200-4700 m: Breeding activity on a lagoon at $4300 \mathrm{~m}$ : Tiny, cone-shaped nest islands; 3 of them with grey, downy young. Some young swimming. At the nest, that is next to the shore, the 2 young are permanently protected by an ad. Some ads. are trying to scare off the intruders by circling and screaming above our heads.

20-27/02/1972. Putina, Puno, 3900-4000 m: Common in the wohle region; solitary or in small groups, with exception of Laguna Checayani, where they occur in large numbers. Numerous nests near the shore (Fig. 31), some on open, shallow water, some within the rush belt. Two young are loudly begging for food, nodding their head.

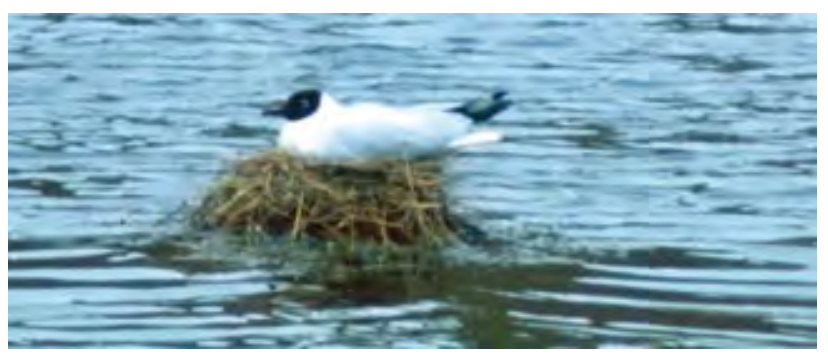

Figure 31. Chroicocephalus serranus breeding. 
Several ad. nearby don't take notice.

09/07/1988. Bay of Paracas, Ica: Several inds., one in alternate, the others in basic plumage.

\section{Sternula lorata}

21/01/1968. Near Punta Salinas, south of Huacho, Lima: Probably breeding activity. Numerous over desert plain. Alarmed by the intruders, they fly close over our heads, screaming. Two ads. carry small fish in their bills.

13-14/02/1970. Lagunillas, Paracas, Ica: Numerous; they steep dive from remarkable hight, snatching the prey from the surface without actually submerging in the water. They swallow their prey in flight.

\section{Larosterna inca}

05/08/1983. Mouth of Rio Mala, Lima: Several ind. bathing in fresh water, strongly flapping their wings, prancing and shaking themselves; they even turn onto their backs.

08/07/1988. Paracas, Ica: Numerous at Punta Pejerrey and the Islas Ballestas; several immatures.

Mass mortality of seabirds 1972

23/06/1972. Playa Chira, south of Lima: 2 fresh carcasses out of 99 dead birds.

08/08/1972. Same place: 26 carcasses, most of them immatures, out of 312 dead birds.

\section{Chlidonias niger}

Boreal migrant

18/11/1967. Totoral de Villa, south of Lima: Ind. circling over marshland and lagoon.

\section{RYNCHOPIDAE}

\section{Rynchops niger}

Boreal migrant

Sighted on coast of Ancash, Lima and Ica from Oct to May, most frequently in Feb and Apr; solitary or in small flocks, also in large associations.

11-17/02/1969. Playa Vineta, south of Paracas, Ica: Every day a congregation of more than 500 inds. gathers on the beach, always aligned head first towards the often strong wind (Fig. 32).

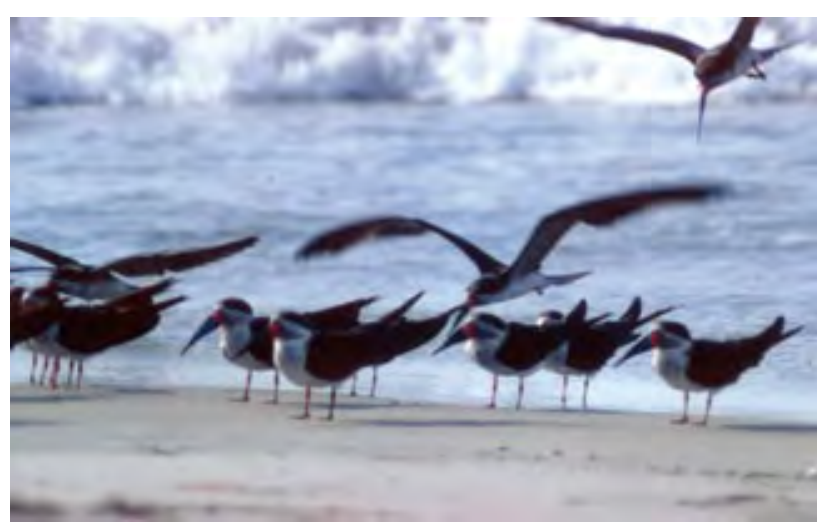

Figure 32. Rynchops niger.

\section{COLUMBIFORMES COLUMBIDAE}

\section{Columbina talpacoti}

24/01 - 02/02/1973. Yarinacocha, Pucallpa, Ucayali, 200 m: Very numerous in second growth and cultivated areas. Nest in a plantation on a tutumo tree, about $2 \mathrm{~m}$ above ground: a platform barely $10 \mathrm{~cm}$ wide with two white eggs.

\section{Columbina cruziana}

All records refer to the urban area of Miraflores/Lima (Fig. 33).

The diagram shows, that in the mentioned area, there are two periods of reproduction. The main breeding season lasts from March to June, the secondary from Oct to Dec.

Reproductive periods of Columbina cruziana

\begin{tabular}{|c|c|c|c|c|c|c|c|c|c|c|c|c|}
\hline & 1 & 2 & 3 & 4 & 5 & 6 & 7 & 8 & 9 & 10 & 11 & 12 \\
\hline c & & & 1 & | & & & & & | _... & & | & \\
\hline $\mathrm{n}$ & & | & 11 & 1 & & & & & & 1 & & \\
\hline$b$ & & 1 & -.-- & --- & ---- & F & & & & & -1 & 11 \\
\hline$f$ & & & - & & 11 & --- & 1 & & & & --- & \\
\hline j & & & -- & -.- & & & & & 1 & & --- & \\
\hline
\end{tabular}

Figure 33. 1-12: month/year; c: courting; n: nest-building; b: breeding; f: feeding at nest; | single record; --- observation period.

Courting.- Typical courting scenes:

a) Male and female are sitting very closely on the branch of a tree. Their bills hooked, they move their heads vehemently up and down. In the following sequence, the male 'cuddles' his mate by plucking her throat and head, especially around eye and bill. It is followed by a short mating act. Now its the turn of the female to caress her mate, with the difference, that she plucks him more softly. After that, both dedicate themselves to put their plumage in order without taking notice of each other but always keeping in touch.

b) Male and female are hopping and fluttering around on the ground. The male is following his mate closely. Occ. it approaches her with a short jump, followed by a bow and a short croaking - throat feathers raised, tail spread. The female is not impressed and goes on pitter-pattering around.

\section{Breeding record (28/02 - 02/04/1969)}

28/02. Ind. gathering nesting material in our garden. It picks up a straw here and a twig there, carefully choosing the adequate material. Finally it carries a fitting piece to the nesting site: a horizontal branch of a high Euaclyptus tree 3-4 m above the ground. For the moment, the nest consists just of a few stems.

02/03. In the morning: The nest has obviously been completed. The loosely arranged, fragile construction measures $8-9 \mathrm{~cm}$ in diameter and is $3-4 \mathrm{~cm}$ high. $6.30 \mathrm{pm}$ : One ind. is sitting on the nest, the other is present nearby.

03/03. The first egg has been deposited before $8.30 \mathrm{am}$. The nest is guarded the whole day.

04/03. The second egg has been laid between 8.30 am and 6.30 $\mathrm{pm}$. The eggs measure $18 \times 24 / 18 \times 23 \mathrm{~mm}$. During the next two weeks the pair is dedicated to the breeding task, which is shared by both sexes. (To identify the male, I relied on his caracteristic croaking call.) They leave the clutch only for short periods unprotected.

17/03, $7.00-7.45 \mathrm{am}$ : The breeding ad. is sitting motionless for several minutes, plumage fluffed, eyes half shut. Fully awake, it begins to straighten ist plumage. During the next $12 \mathrm{~min}$, it moves about in the nest, restlessly cuddling and turning around. Occ. it plucks playfully at some protruding stems at the rim of the nest. For the rest of the time it dozes along.

18/03, $9.45-10.15 \mathrm{am}$ : The breeding male is visited 6 times by his mate. Each time, the same ceremony takes place: The female arrives from a nearby cottonfield, carrying some nesting material. She lands on an outer branch and approaches the nest by foot. Occ. she is greeted by her mate by the characteristic croaking call. The female climbs immediatly onto the back of her mate to deliver the stem or twig she has brought with her. She does it in a somewhat ceremonious way, nodding her 
head affectionately. The male inserts the stem into the nest, sometimes assisted by the female. Once the job is done, she leaves again, only to return a few minutes later with a new 'gift'.

20/03, $9.30 \mathrm{am}$ : The female is breeding. As soon as the male approaches, she leaves the nest immediatly. The male emits a croaking call, approaches the nest cautiously and takes over the breeding. $10.30 \mathrm{am}$ : The first egg (marked red) has cracked. With some vigorous movements, the fledgeling manages to widen the gap.

21/03. The second young has hatched between 3 and $6 \mathrm{pm}$.

24/03, $7.30 \mathrm{am}$ : The female is attending to the fledglings.

27/03, 9 am: The male is sitting on the nest. After a while the fledglings raise their head from beneath him. The begging gestures of the young are not attended by the ad.

29/03 Both fledglings have opened their eyes. The first born is now more than double the size of its sibling. $9.30-10.45$ $\mathrm{am}$ : Three feedings recorded; both parents participate in the task. The fledglings - occ. both at the same time - are besieging the feeding ad. by vehemently pushing their bill sideways into its gorge. The regurgitating process may last several minutes.

01/04. The older fledgling has left the nest (the day before it was still there). The younger looks underdeveloped.

02/04. The second fledgeling found dead. Last feeding recorded the day before.

- $\quad$ Nest building: 2 days

- $\quad$ Breeding: 17 days

- $\quad$ Feeding at nest: 12 days

August 1970. Nest with two eggs on a date palm in a school yard, 3-4 $\mathrm{m}$ above the ground (Fig. 34)

- $\quad$ Breeding: 16 days

- $\quad$ Feeding at nest: 12 days

Oct/Nov 1970. Nest in a young Araucaria, about $2 \mathrm{~m}$ high (Fig. 35/36).

- $\quad$ Nest building: 2 days

- $\quad$ Egg deposition 23./24.10.; hatched 08./09.11.

- Breeding: 16 days

- $\quad$ Feeding at nest: 13 days

18/11/1974. Four tipa trees in a school yard with a total of 16 nests (Fig. 37). All nests are occupied. Since the trees are just beginning to bud, the nests are all visible. Minimal distance between two nests: $1.50 \mathrm{~m}$.

\section{Metropelia ceciliae}

\section{Sightings}

NP: Cajamarca 1500-2000/2700 m, La Libertad 1200/1500/1700 m

CP*: Ancash 2600-3900 m, Pasco 3400 m, Lima 800/1000-3900 m

SP: Ayacucho 3000-3800 m, Apurímac 1500-2500 m, Cusco 3000 m, Puno 3900-4000 m, Arequipa 3400 m.

*most frequently between 2000 and $3500 \mathrm{~m}$.

Behavior/Habitat.- In pairs or small flocks of up to 12 inds. in semi-arid areas with columnar cacti, montane scrub, fields, pastures and villages.

29/09/1971. Contumazá, Cajamarca, 2700 m: Nest building ind. at the edge of the village. It disappears with a long straw beneath a curved tile of an adobe construction. A few minutes later, it picks up the next piece on the adjacent pasture.

\section{Metropelia melanoptera}

\section{Sightings/Behavior}

CP: Lima 1500/2800/3000-4000 m

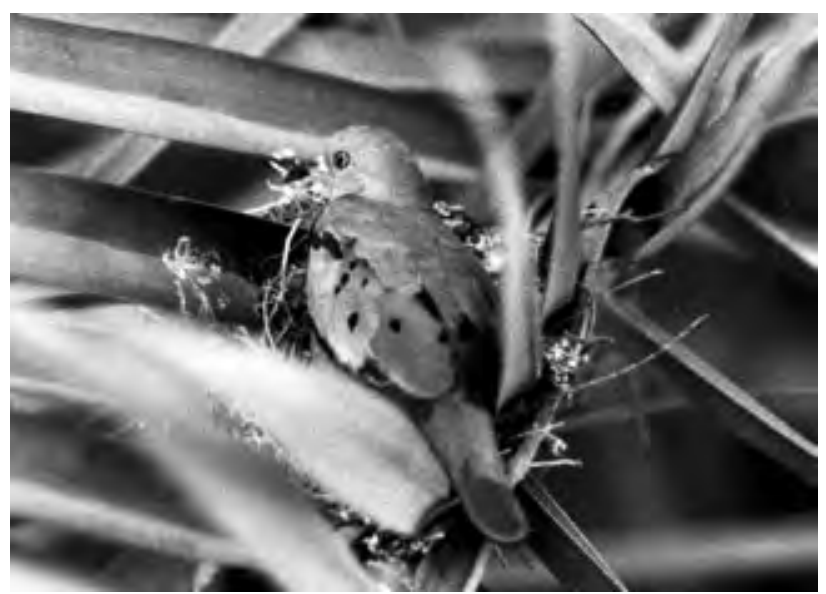

Figure 34. Columbina cruziana breeding.

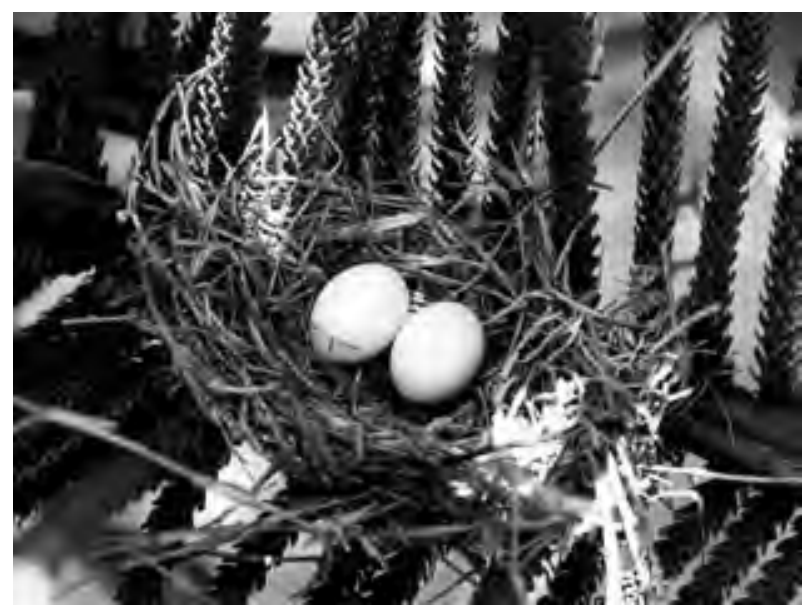

Figure 35. Columbina cruziana: nest with clutch.

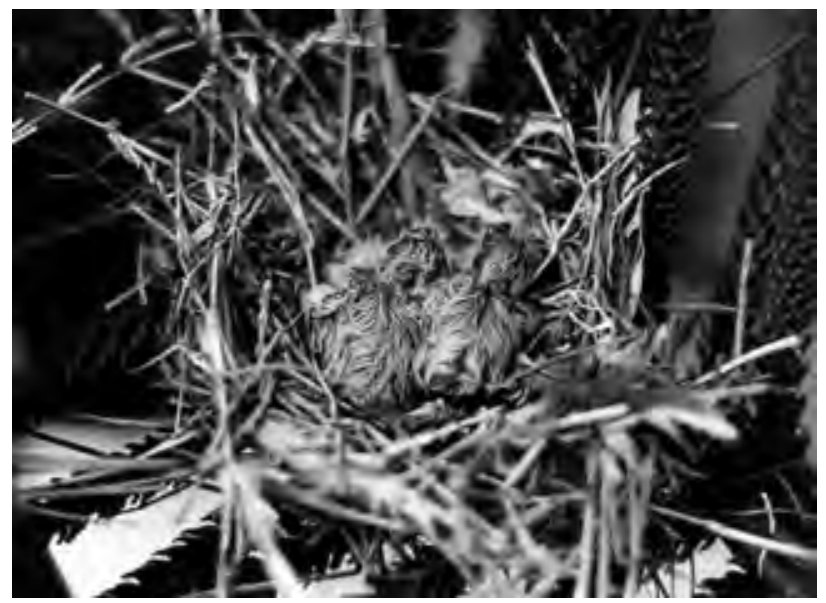

Figure 36. Columbina cruziana: nest with young.

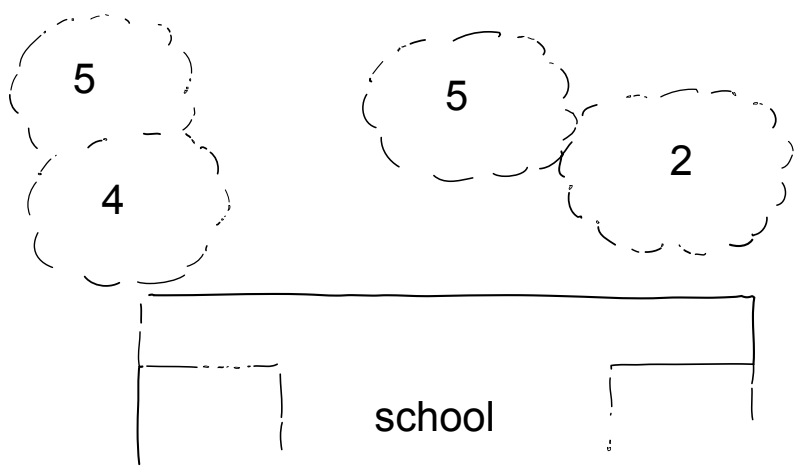

Figure 37. Nest colony of Columbina cruziana. 
SP: Ayacucho 3000-3800 m, Puno 3900 m, Arequipa 3000-4200 m

Often in pairs or small groups; very numerous and in large flocks in the region of Putina, Puno and between Puquio and Pausa, Ayacucho.

05/06/1972. Quebrada Tinajas, Lurin Valley, Lima, 1500 m: 2 separate pairs in a semi-arid area with numerous columnar cacti and a dried out seasonal vegetation.

\section{Patagioenas maculosa}

16-17/06/1968. Pampas Canyon, Ayacucho: a) Tarhuy, 3400 m: Several inds. in montane scrub with small cultivated plots. b) Orongoy, $2800 \mathrm{~m}$ : Pair in a quebrada with dense vegetation.

June 1970/ July 1979. Beneath Yauyos, Cañete Valley, Lima, 2700 $\mathrm{m}$ : Several inds. in lush river edge vegetation dominated by Salix humboldtiana.

14/07/1988. Achomas, Colca Valley, Arequipa, 3400 m: Group of 6 inds. foraging on a harvested wheat field.

13/03/2003. Above Puno, ca. 4000 m: Ind. in a shady grove surrounded by fields, hedges and scrub.

\section{Patagioenas fasciata}

The following sightings refer to the humid montane forest of Zárate, Rímac Valley, Lima, 2900-3100 m:

$15 / 09 / 1963$. Perched in groups of 3 or 4 inds. on tree tops. Occ. they take to the air (as a group) describe an ample curve and return to the starting point.

13/06/1965. Like 15.09.63, but no collective flights. Occ. owl-like call. Leftovers on a stone beneath a tree: feathers and the contents of the crop.

$11-12 / 06 / 1966$. Numerous; in the morning up to 5 inds. on top of Oreopanax trees. Towards midday also in lower vegetation but not on the ground.

07/07/1968. Numerous; exceptionally on the ground.

$22-23 / 03 / 1970$. Sporadic on tree tops; ind. in montane scrub at $2600 \mathrm{~m}$.

\section{Sightings outside Zárate:}

03/08/1966. Aricapampa, Marańón Valley, La Libertad, 2400 m: At dusk 4 inds. in a lush quebrada perched on a tree top.

14/10/1967. Surco, Rímac Valley, Lima, 2400 m: 8-10 inds. temporarily on a Schinus molle, some perched in pairs in close proximity.

08/04/2003. San Luis, Callejón de Conchucos, Ancash, ca. 3400 $\mathrm{m}$ : Ind. flying over a rock-strewn slope towards a nearby patch of humid montane forest.

\section{Zenaida meloda}

Vertical distribution.- Sightings exceeding the max. alt. stated by BP (locally up to $1000 \mathrm{~m}$ ):

\section{NP: Casma Valley, Ancash up to $\mathbf{1 4 0 0 ~ m ~}$}

CP: Santa Eulalia Valley up to $\mathbf{1 8 0 0} \mathbf{~ m}$, Canta Valley up to $\mathbf{1 7 0 0}$ m, Rímac Valley (Quebrada Tapicara) up to $\mathbf{1 9 0 0} \mathbf{~ m}$, Cañete Valley up to $1600 \mathrm{~m}$.

\section{SP: Cotahuasi Valley, Arequipa 2000-2200m}

Courting/Breeding.- The courting and breeding period in Miraflores/Lima and Chosica, Rímac Valley, Lima $800 \mathrm{~m}$, lasts from June to March. In the display flight $Z$. meloda rises steeply to the culmination point, then glides down with spread wings in a wide, flat curve. Song activity is most intense in the morning, beginning before dawn. It diminishes during the middle of the day and increases again in the afternoon and lasts till dusk.

16/11/1972. Miraflores/Lima: From 5.30 to 6 pm about 50 inds. gather in two giant bamboo bushes to roost. They share the place with numerous Columbina cruziana and Passer domesticus.
Jan 1999. Miraflores/Lima: Breeding on a Spathodea campanulata, about $5 \mathrm{~m}$ above the ground. In one occ. the unguarded nest is inspected by 3 male (!) Molothrus bonariensis.

14/02/2003. Mirafloes/Lima: Nest building in a Bougainvillea that spreads over a garden wall. Ind. gathers repeatedly twigs and branches from within a bush (not from the ground). A mating ritual takes place on top of the wall. It lasts about $15 \mathrm{~min}$.

\section{Zenaida auriculata}

In CP recorded most frequently between 1500 and $3500 \mathrm{~m}$ in small groups and medium sized flocks of up to 100 ind.

31/07/1963. Near Ayacucho, $2900 \mathrm{~m}$ : Numerous in a quebrada with creek and rich vegetation. Nest about $2,5 \mathrm{~m}$ high on a scrub with two white eggs; loose platform made of stems and twigs, about $13 \mathrm{~cm}$ in diameter.

\section{Leptotila verreauxi}

\section{Sightings}

NP: West slope: Coast of Tumbes, Piura $800 \mathrm{~m}$, Lambayeque 200600m, La Libertad 1500-2000/2400/2800 m

East slope: Cajamarca 300-2500 m, Amazonas 1600-2500 m

CP: West slope: Coast of Ancash, Lima 0/400 (lomas) /800/1400$2600 \mathrm{~m}$.

East slope: Junín 700 m, Ayacucho 600 m

SP: East slope: Apurímac $2400 \mathrm{~m}$

24/07/1966. Lurin Valley, Lima, $1400 \mathrm{~m}$ : Nest in riparian wood (mainly Alnus). The nest is a rather strong platform made of twigs and stems; diameter ca. $25 \mathrm{~cm}$. An ad. and a well developed fledgling are looking over the rim of the nest.

02-03/08/1966 Aricapampa, Marañón Valley, La Libertad, 2400 $\mathrm{m}$ : Numerous in a quebrada with lush vegetation. During the day, they perch on trees or hide in dense scrub. Late in the afternoon, they forage on the ground at the edge of the thicket. When alarmed, they open their tail like a fan, close it again and raise it at the same time. Then they lower it slowly to the original position.

03/07/1972. Villa del Progreso, Chanchamayo Valley, Junín, 700 m: Common in secondary growth. Nest with 2 white eggs $(28 \times 21 / 30 \times 21$ $\mathrm{mm}$ ) in a grass bush; loose platform made of dry grass; diameter 20-25 cm (Fig. 38).

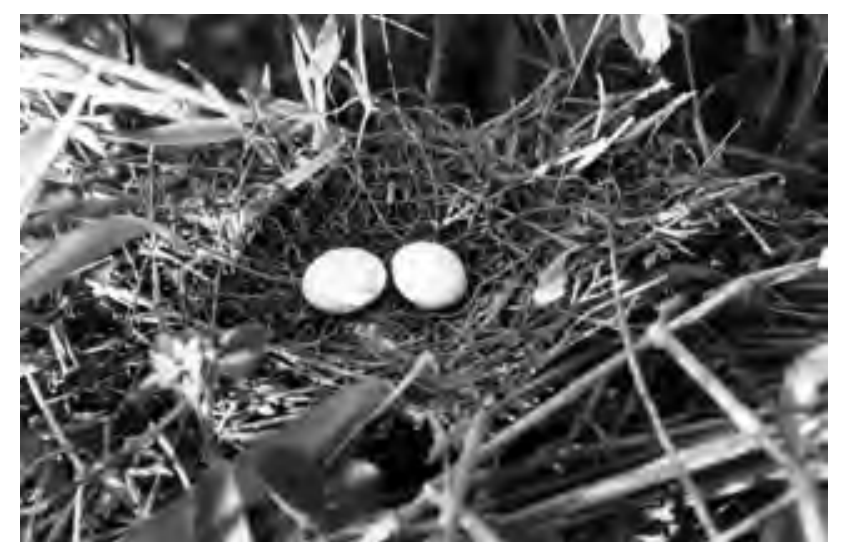

Figure 38. Nest of Leptotila verreauxi.

\section{PSitTACIFORMES}

PSITTACIDAE

The distinction of the two following species are based on geographic distribution and habitat as described in BP.

\section{Aratinga wagleri}

\section{Sightings}

NP: La Libertad, Marañón Valley, 1300 m 
CP: Lima: Huaura Valley 2600 m, Canta Valley 1700 m, Santa Eulalia Valley, 1600 m, Cañete Valley 2700/3200 m; Ica: Pisco Valley $1700 / 2200 \mathrm{~m}$.

\section{SP: Apurímac, Pampas Canyon 1300-2400 m}

08-12/06/1967. Chiuchín, Huaura Valley, Lima, 2600 m: Several times recorded in flocks of up to 20 inds. foraging in the cornfields at the outskirts of the village. In the evening they regularly perform a kind of flight show: They take to the air from the mountain slope, then glide back in a wide curve to the original place; after a while, they repeat the flight. Nesting place in a vertical cliff along the stream: About 20 holes are distributed over a length of $60 \mathrm{~m}, 6$ to 10 meters above the ground. Most entrances are marked with white droppings. The cliff is exposed to the shade during the entire day (Fig. 39).

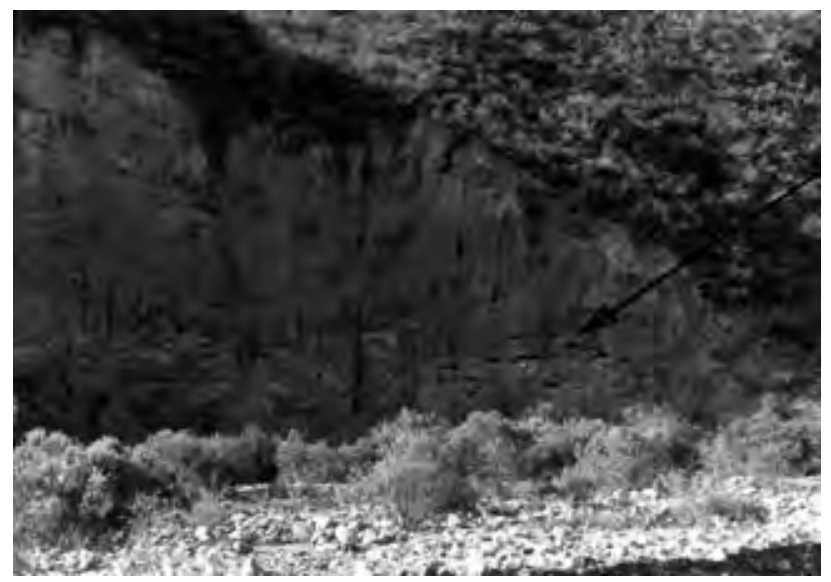

Figure 39. Aratinga wagleri: breeding caves (arrow).

14-19/06/1968. Pampas Canyon, Apurímac/Ayacucho: a) Puente Santa Rosa, 1300 m: Numerous in an abandoned orchard at dusk and at dawn; they screech permanently. They feed on pods of Acacia-like trees. b) Between Orongoy and Cocas, $1400 \mathrm{~m}: 5$ inds. roost in a rocky cliff high above the Pampas river. c) Below Hacienda Cocas: Numerous in semi arid area with cacti and scattered trees. d) Hacienda Toxama, $2400 \mathrm{~m}$ : Flock of over 100 inds. at 5.30 pm flying upwards the valley.

27/06/1970. Beneath Yauyos, Cañete Valley, Lima, 2700 m: In the morning and in the evening flock of 10-15 inds. in montane scrub.

07/07/1979. Above Yauyos, Cańete Valley, Lima, ca. 3200 m: Between 6 and 6.30 am large flock of 100-200 inds. in flight over mountain slope.

13/07/1997. Chagual, Marañón Valley, La Libertad, 1300 m: Numerous; they leave their roosting place in a dry quebrada with scattered trees at 6.30 and fly down to the orchards outside the village. They gather preferably on mango trees, although the fruits are not ripe yet.

\section{Aratinga mitrata}

20-23/07/1976. Limatambo, Cusco 2600-ca.3000 m: Numerous in cultivated areas, montane scrub and river edge vegetation, where they feed on the pods of Pisonia trees. Occ. in pairs, more often in groups; flocks of 100-200 inds. are not rare. Voice: During flight strident, noisy screeches. When feeding, they temporarly fell silent, then they chatter again. They emit two different calls: qyac'qyac'qyac and a whinny-like noise. They do not mix the two calls.

17/04/2005. Region of Lamud, Amazonas: a) Karajía, 2400 m: In the morning flock of about 20 ind. in a vertical cliff (archeological site); later over the humid montane forest below, screaming. b) Some ind. in a cornfield near the cavern of Quiocta (relic of humid montane forest), ca. $2500 \mathrm{~m}$. c) Flock in flight over Lamud, $2200 \mathrm{~m}$.

\section{Aratinga erythrogenys}

14-15/02/1964. Hacienda Mallares, Sullana, Piura, 200-800m: In semi-arid area with scrub and scattered trees and in deciduous forest. Perches on high trees, like Bombax; very noisy.

\section{Forpus coelestis}

Sightings/Habitat.- Tumbes, Piura 200-800m, Lambayeque 200 $400 \mathrm{~m}$, Cajamarca 500-1000/1600 m and La Libertad $1500 \mathrm{~m}$ (Fig. 40). In small groups of up to 10 inds. in deciduous forest, semi-arid vegetation with scrub and cacti, Prosopis and Bombax forest, riparian vegetation.

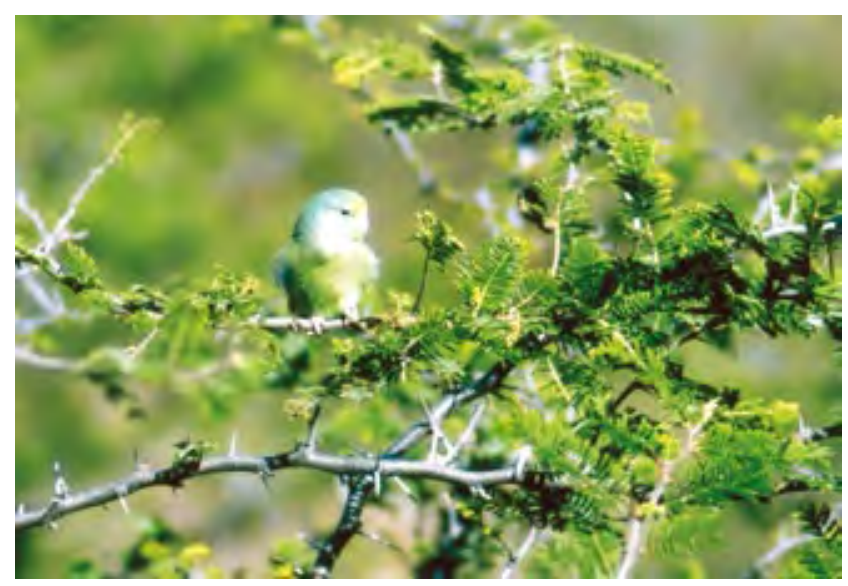

Figure 40. Forpus coelestis.

\section{Psilopsiagon aurifrons}

\section{Sightings}

CP: Lima 0-800/1200/1900/2300/3200/3500 m, Huancavelica $1900-3300 \mathrm{~m}$

\section{SP: Arequipa 500 m, Puno 3800-4000 m}

Max. alt.: Three records, that exceed the $3100 \mathrm{~m}$ limit on west slope, stated by BP: Casta, Santa Eulalia Valley, Lima, 3200 m; Huaytará, Pisco Valley, Huancavelica, 3300 m; Huarochirí, Mala Valley, Lima, $3500 \mathrm{~m}$.

Habitat/Behavior.- Frequently in medium sized flocks of 10-25 and up to 50 inds. in montane scrub, river edge vegetation, fields, orchards, lomas (Atocongo, Lachay). They feed on a great variety of fruits and seeds, e.g. Casuarina and sunflower seeds, Schninus berries corn and peaches.

Regular flights between (presumable) roosting and feeding places: San Antonio, Miraflores/Lima: Repeatedly recorded in the morning between 6.30 and 7.30 flying in south-eastern direction (possible feeding places: Atocongo, Monterrico) and in the evening between 6 and 6:30 in the opposit direction (possible roosting places: Cliffs of Miraflores and Barranco).

Urbanización California, Chosica, Lima, 800 m: Similar phenomenon: Flocks of 10-30 inds. flying between 5 and $6 \mathrm{pm}$ from their feeding place (rich vegetation along irrigation channel and scrub covered slope below) to the opposite side of the valley (El Bosque). Return flights occ. recorded bewteen 7 and $10 \mathrm{am}$.

\section{Bolborhynchus orbygnesius}

13/061965. Zárate, Rimac Valley, Lima, 2900-3000 m: 2 or 3 small groups at the lower edge of the forest. Next morning 15-20 inds. foraging fruits on a thorn bush.

26/06/1966. Chumcha, Santa Eulalia Valley, Lima, 4100 m: 6 inds. in flight over Polylepis wood.

14-15/06/1968. Pampas Canyon, Apurímac/Ayacucho: Group on both sides of the canyon in dense vegetation (scrub and trees): near Humaca, $3100 \mathrm{~m}$ and between Mollebamba and Orongoy, $3500 \mathrm{~m}$.

\section{CUCULIFORMES \\ CuCULIDAE}

\section{Crortophaga sulcirostris}

Sightings.- Coast from Tumbes to Lima; Tacna. Coastal valleys of Lima: Chicama 1500-2000 m; Chancay 1200 m; Rímac 0-800/2200 
m; Santa Eulalia Valley 1600/1800 m; Mala Valley 0-1700 m.

Behavior.- In small groups of up to a dozen inds. They forage on the ground on pastures and fields; very often together with grazing cattle (Fig. 41).

Voice.- Call: occ.starting with a low a qsew'qsew followed by a sharp qsYew'qsYew or qsida'qsida. Collective song: a slightly ascending and increasing heweeen.

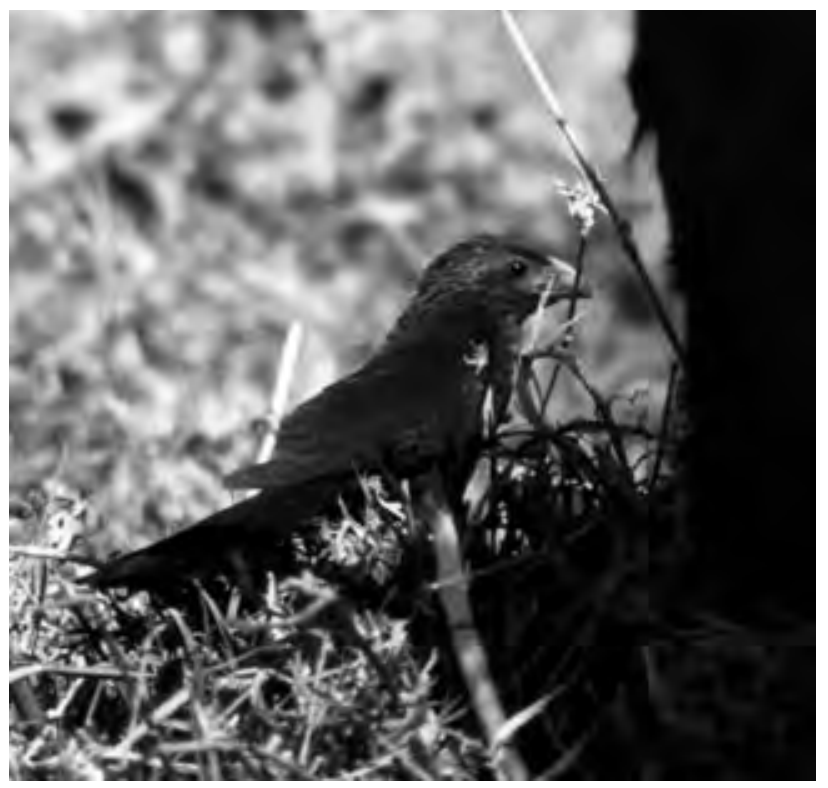

Figure 41. Crotophaga sulcirostris with grazing cattle.

Oct 1963. Sta. Catalina, La Victoria/Lima: Regularly but only temporarly in a small untended park.

01-03/11/1963. Santa Eulalia Valley, Lima, 1800 m: Numerous in pasture land boarderd with hedges and chirimoya trees.; mostly in pairs. About 10 inds. together with Mimus longicaudatus on a recently irrigated pasture, picking up small prey, that is trying to escape the flood. At dusk 7 inds. assemble on a dehydrated Acacia tree at the edge of a thicket. I flushed them twice, but they always returned to their roost, huddling against one another.

25/08/1968. Pachacamac, Lurin Valley, Lima: About a dozen inds. are following a tractor, that is plowing a field. Some are sitting on the clods, observing the scene. Others hop or jump or walk crow-like in order to pick up the varied prey, that the plow is bringing to light.

17/11/1968. Mala Valley, $100 \mathrm{~m}$, Lima: 5 inds. are sitting beside a burning heap of weed at the edge of a field (Fig. 42). When they spot a prey, that is trying to escape, they pounce on it, occ. 2 or 3 inds. at the same time. They do not back away from the smoke, that occ. besieges them. They stay just about $30 \mathrm{~cm}$ away from the slowly extending flames. To grab a fleeing insect, they will risk going even closer.

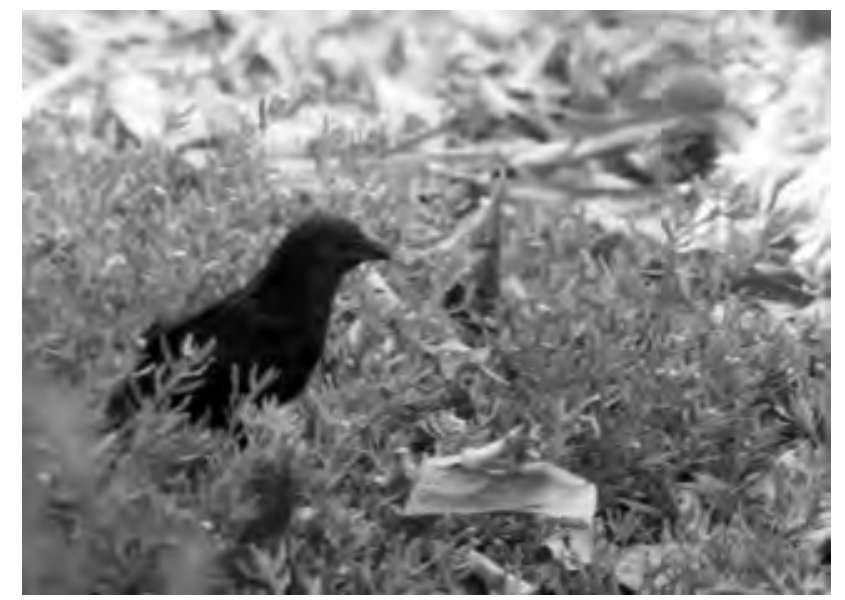

Figure 42. Crotophaga sulcirostris waiting for prey.
04/08/1983. Urbanización California, Chosica, Lima, 800 m: 0n two occ. food carrying ind.

20/04/2005. Chamaya Valley, Cajamarca, ca. 800 m: Ricefields and dense vegetation at the foot of an arid mountain slope. Bulky nest on a tree about $4 \mathrm{~m}$ above the ground. It is made of losely piled up branches and twigs, $30-40 \mathrm{~cm}$ in diameter. Ad. arrives with a big grasshopper to feed a nearly full fledged young.

\section{STRIGIFORMES \\ TYTONIDAE}

\section{Tyto alba}

03/01/1965. Naña, Rímac Valley, Lima, 500 m: Dead ind. at the road side.

$13 / 11 / 1966$. Tumbes: Ind. calls from a roof in front of the church at $8.30 \mathrm{pm}$; ind. in flight.

02/05/1968. Callao/Lima: Ind. captured by workers of an industrial mill (later released).

28/08/1971. Pisco, Ica: Dead ind. hanging from a power line at the road to Tambo Colorado.

\section{STRIGIDAE}

\section{Megascops koepckeae}

15/09/1963. Zárate, Rímac Valley, Lima, 3000 m: At dusk ind. perched on a lower branch of a big Oreopanax tree with raised 'ear' tufts.

18/06/1965. Same place: Voice recorded between 6 an $6.30 \mathrm{pm:}$ ooc'ooc'ooc; repeated 8 to 10 times; slightly ascending and increasing; the last notes slightly falling and diminishing.

\section{Bubo virginianus}

28/02/1964. Viscas, Mala Valley, Lima, 1800 m: (9 am) Ind. flushed on its roost on an Acacia in a dry, narrow quebrada. It settels about 100 $\mathrm{m}$ away in a small niche situated at a crumbling cliff (Fig. 43). It stares at me with its wonderful golden eyes. It raises and lowers nervously its 'ear' tufts. As a sign of alertness, it turns its head around and upward. When I try to get closer, it ruffles its plumage menacingly. Suddenly a Falco sparverius settles on a cactus at the edge of the cliff. Its high pitched kli'kli'kli attracts two inds. of the same species. They start to harrass the big owl by alternately plunging down the ravine passing by the niche as close as possible and simultaneously emitting their aggressive call. The only reaction of $B$. virginianus: It shuts its eyes each time the troublemakers fly past.

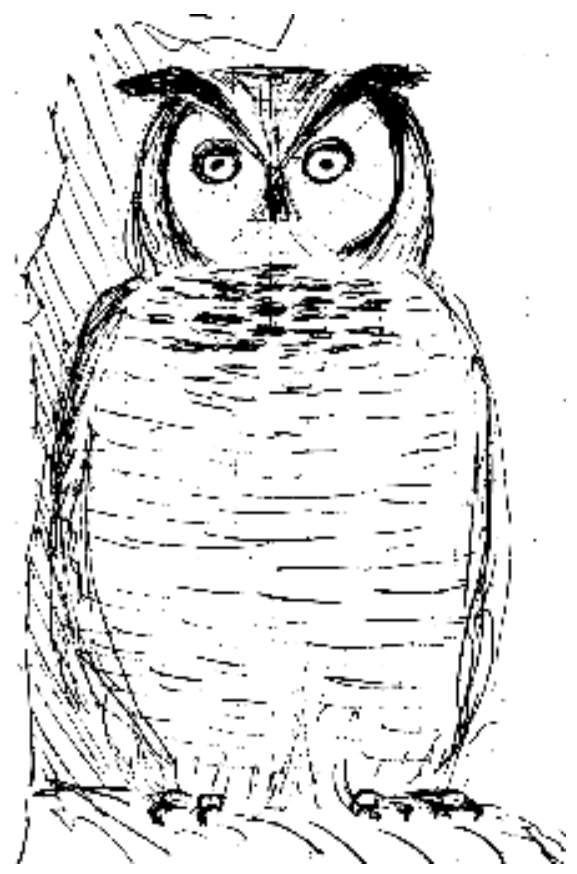

Figure 43. Bubo virginianus. 


\section{Glaucidium peruanum}

\section{Sightings}

Piura: Amotape mountains, 700 m; riparian forest along Rio Chira, near Sullana

Lima: Rímac Valley, 2300-2900 m; Santa Eulalia Valley, 1600 m; Cañete Valley, $2700 \mathrm{~m}$; voice records in the urban area of Lima (at dusk) and Urbanización California, Chosica, $800 \mathrm{~m}$ (from late afternoon till early in the morning).

Habitat/Behavior.- In deciduous forest, riparian forest, montane scrub, gardens. Old willows (Salix humboldtiana) seem to be the favorit roosting places (3 records). When alarmed, it nervously raises and flickers its tail. On two occ., two hummingbirds harass a roosting $G$. peruanum. They succeed in displacing it.

\section{Athene cunicularia}

Sightings.- Coast and west slope: from Piura to Ica; Tacna. (Ancash 2200 m, Lima up to 1100 m). Highland: Junín 4100 m, Puno 3900 m.

Habitat.- Urban areas, fields, gramadales, lomas (Atocongo, Pacta), sand or stone deserts at the edge of irrigated land, huacas (precolumbian adobe constructions; recorded at 6 different sites), dry valleys with columnar cacti, arid montane scrub, puna grassland (Fig. 44/45).
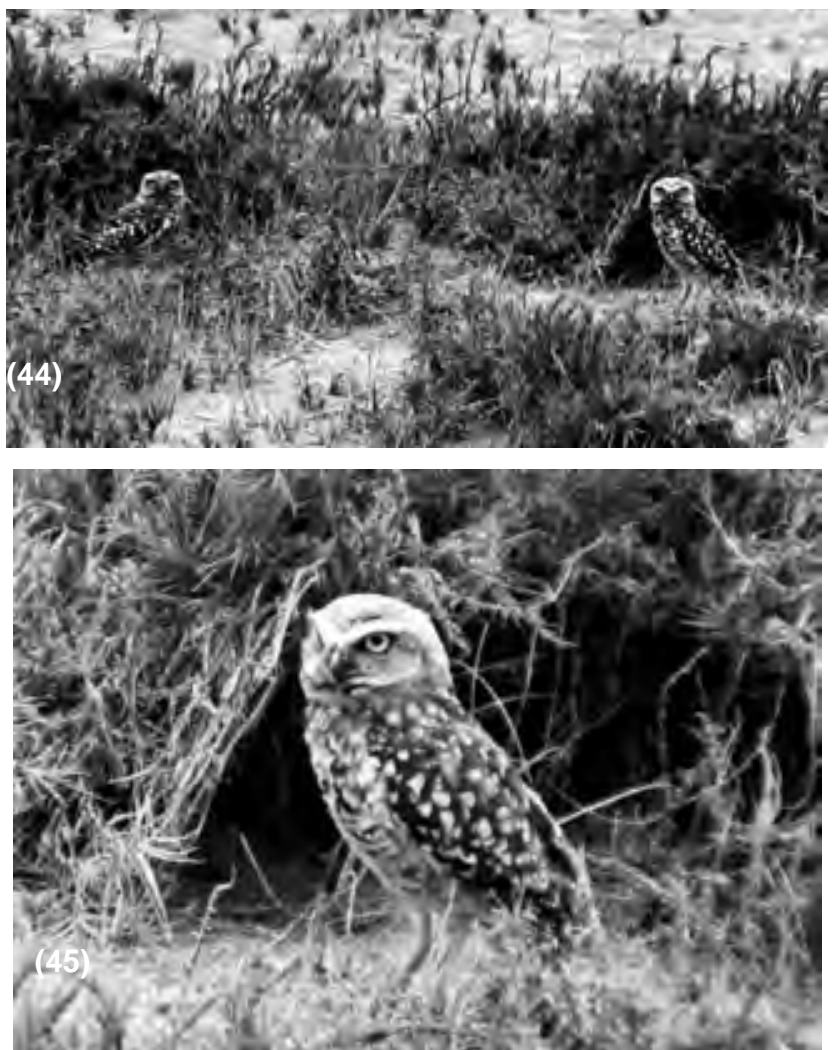

Figure 44-45. Athene cunicularia in front of their burrow (photos by Frank Frazier).

Behavior.- Solitary, in pairs or family groups (up to 5 inds.); on the ground or on low perches like adobe walls, boulders and cacti; occ. on trees (Prosopis, Casuarina). When alarmed it reacts in different ways: As a sign of alertness, it turns its head nervously to all sides reaching nearly $360^{\circ}$ as well as upward at an angle of about $90^{\circ}$. Another expression of alarm is its charcteristic warning call, a penetrant qyaaac'qyac'qyac'qyac often accompanied by alternatly stretching and crouching. When fully raised, A. cunicularia reaches an impressive size thanks to its long legs. To chase away an intruder from its breeding area, it feigns attack by passing close over his head, screeching.

\section{Breeding burrows} Lima:

a) Huaca Limatambo in the middle of a cotton field, La Victoria/
April/May 1963. Pair perched regularly on 2-3 m high adobe walls, occ. together with a third (probably young) ind.; horizontal burrow; entrance about $15 \mathrm{~cm}$ wide. Numerous pellets at the foot of the walls: some containing bones and hairs of small rodents, the others show remains of diverse invertebrates.

27/04/1963. Ind. attacks and expells a straying dog.

14/07/1963. Clogged burrow; some fresh pellets.

04/02/1964. Pair perched on an adobe wall; juv. at some distance. There are several newly created (some unfinished) burrows; one is 1.5 $\mathrm{m}$ long. At two entrances dispersed feathers of a small bird (remains of a prey?); fresh pellets.

b) Dry quebrada above Urbanización California, Chosica, Rímac Valley, $800-1000 \mathrm{~m}$ :

08/08/1976. At 6 pm 2 ads. with 3 juvs.: 4 inds. pose immediately above the entrance, the fifth perches on a columnar cactus nearby. One by one they leave their perches and settle at some distance, except for one of the juv. An ad. warns insistently until the young finally withdrews. During my presence, an ad. 'attacked' me three times (Fig. 46).

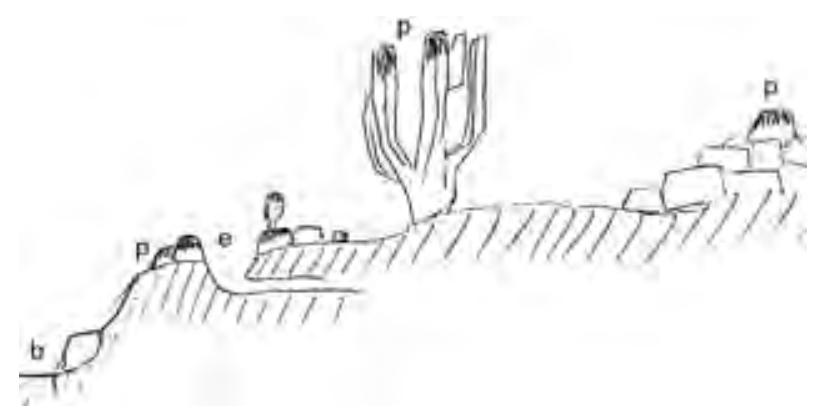

Figure 46. e: entrance of burrow p: perchwith droppings b: bottom of the quebrada.

09/08/1976. 9 am: One of the juvs. crouching at the entrance of the burrow with fluffed plumage, the other perching on a nearby rock. An ad. - alarmed by my presence - settles next to its offspring and begins to warn. Eventually all three leave the place. The ad. continues to call in the background.

Numerous pellets: About $1 / 3$ consist nearly exclusively of bones and hairs of small rodents. About $2 / 3$ are remains of invertebrates: a high percentage of black ants (they feed on the columnar cacti); at least 3 different species of beetles; scorpions ( 3 out of 7 pellets) and one grasshopper. Measures of the pellets: $20-40 \mathrm{~mm}$ long, $12-13 \mathrm{~mm}$ in diameter.

03-17/07/1979. On three occ. a single ind. stays in the neighberhood of the burrow. They behave inconspicuously and depart silently. Fresh pellets at the entrance of the burrow.

05/07/1983. No sign of life; only a few pellets and a complete skeleton of a toad with dehydrated skin.

July 1988. The breeding site described in 76 and 83 is abandoned, the burrow destroyed. Two new sites at a distance of $300 \mathrm{~m}$ (one burrow) and $500 \mathrm{~m}$ (three burrows $\rightarrow$ Fig. 47) have emerged.

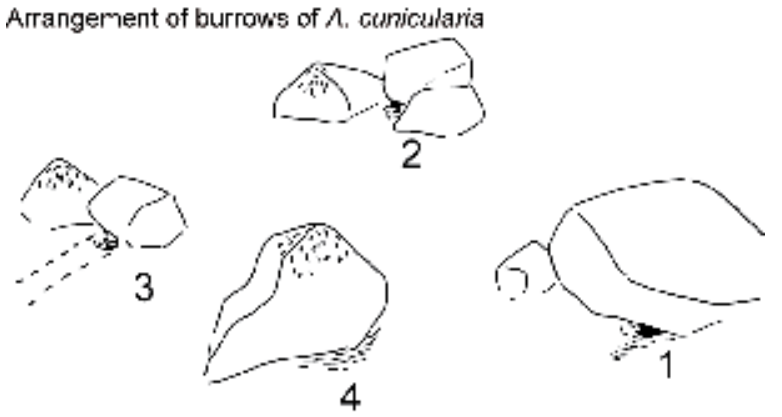

Figure 47. 1-3: burrows (3 caved in, 1,5 m long); 4: scratched out hollow; distance between burrow $1 / 2$ and $2 / 3$ about $2,5 \mathrm{~m}$. 
At both sites I collected a total of 18 fresh pellets in 20 days.

Measures: Length: average $28 \mathrm{~mm}$, min. $21 \mathrm{~mm}$, max. $42 \mathrm{~mm}$; diameter (slightly oval) $10-12 / 12-14 \mathrm{~mm}$.

Composition of the 18 pellets:

- 8 chitin (invertebrates) only

- 3 hairs and bones (rodents) only

- 5 chitin and bones (probably lizard), no hairs.

- 2 chitin, bones, hairs

The chitin remains come mainly from scorpions, a small amount from black beetles. Somewhat less than $2 / 3$ of the overall remains belong to invertebrates. In the 15 pellets, that contained chitin, I found 21 scorpion stingers, up to 3 in one pellet.

Some striking differnces in comparison with the results of 09/08/1976: The high percentage of scorpions, the low percentage of rodents and the absence of ants.

Some singular remains: Longest hollow bone $23 \mathrm{~mm}$, longest mandible $17 \mathrm{~mm}$, leg segment of a grasshopper $21 \mathrm{~mm}$; remains of scorpions: stingers up to $9 \mathrm{~mm}$, pedipalps up to $11 \mathrm{~mm}$.

$15 / 02 / 1999$. Two burrows about $500 \mathrm{~m}$ from the main irrigation channel; entrances beneath a rock, about $4 \mathrm{~m}$ apart from each other. 7-8 perches close to the burrows marked with droppings. At the entrances dispersed bones of small rodents, only few remains of invertebrates.

Five fresh pellets: One consists mainly of bones and hairs plus remains of a scorpion, $2 \frac{1}{2}$ pairs of elytra of a black beetle $(7-8 \mathrm{~mm})$. 4 pellets consist exclusively of chitin, mainly scorpions (each pellet contains 1-2 stingers and 1-3 pedipalps) and a small percentage of black beetles. Measures (in mm): 15/38, 10/25, 11/32, 13/34, 14/33.

c) Quebrada above Chosica, right side of Rímac Valley, $1100 \mathrm{~m}$ :

07/08/1983. Burrow in arid montane scrub with columnar cacti; entrance beneath a rock (Fig. 48). Two boulders - one $5 \mathrm{~m}$ the other $8 \mathrm{~m}$ from the entrance - are strongly marked with droppings. An ind., perched on one of them, withdraws silently.

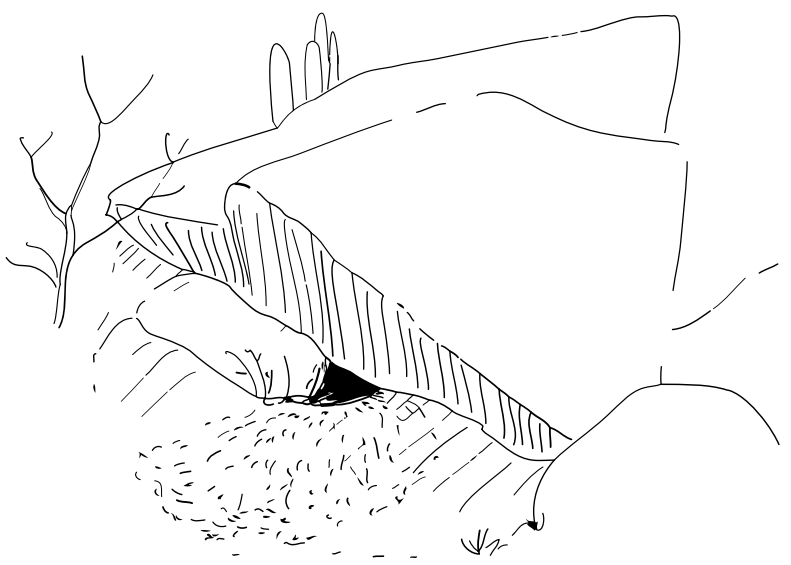

Figure 48. Burrow of Athene cunicularia.

Numerous, partially decayed pellets. I examined 15 of them: They consist exclusively of remains of invertebrates, mainly scorpions, followed by a black beetle. Not a single bone!

d) Samaca, Rio Ica, $200 \mathrm{~m}$ :

17-21/02/1999. Numerous burrows in the transition zone between river edge vegetation and sand desert. Two pairs perch regularly near their burrows at a distance of about $400 \mathrm{~m}$. Frequent calls at dusk and during the night. Ind. perched for half an hour on Prosopis.

Composition of 15 examined pellets deposited near the entrance of a burrow (Fig. 49):

- 9 chitin only (small brown scorpion)

- 5 hairs and bones only

- 1 hairs and bones and numerous elytra of a black beetle

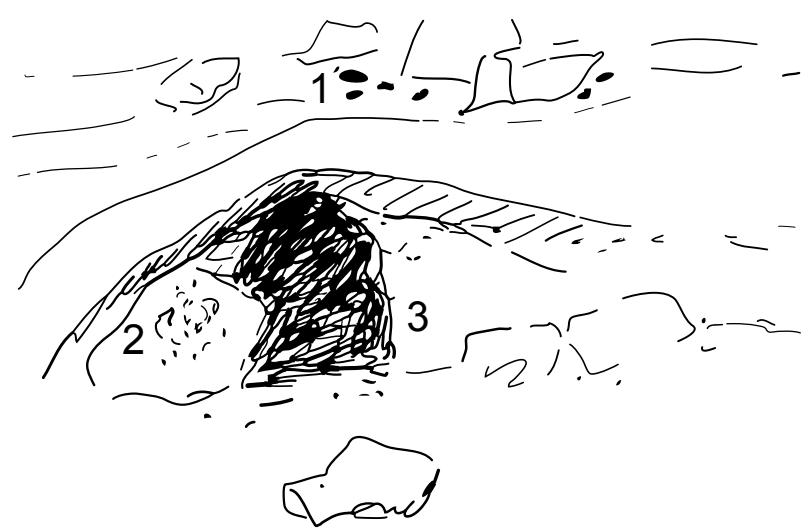

Figure 49. Burrow of Athene cunicularia; 1: pellets 2: perch $\quad 3$ : entrance.

Measures (in mm): 10/26, 12/28, 11/27, 11/32, 11/30, 11/27, $13 / 34,12 / 28,12 / 27,11 / 24,11 / 28,11 / 25,11 / 17,11 / 18$

In addition dispersed single bones of a rodent: pelvis $32 \mathrm{~mm}$, thigh $28 \mathrm{~mm}$, mandible $20 \mathrm{~mm}$.

\section{Asio flammeus}

05/01/1966. Mouth of Rio Sechín, Casma, Ancash: Ind. at 8 am in extended gramadal. It criss-crosses low over the ground in search of prey for quite a long time (Fig. 50).

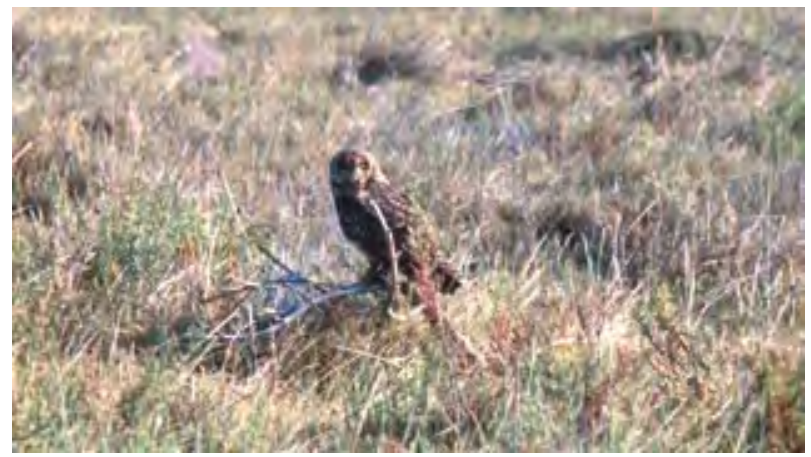

Figure 50. Asio flammeus.

\section{CAPRIMULGIFORMES STEATORNITIDAE}

131. Staetornis caripensis

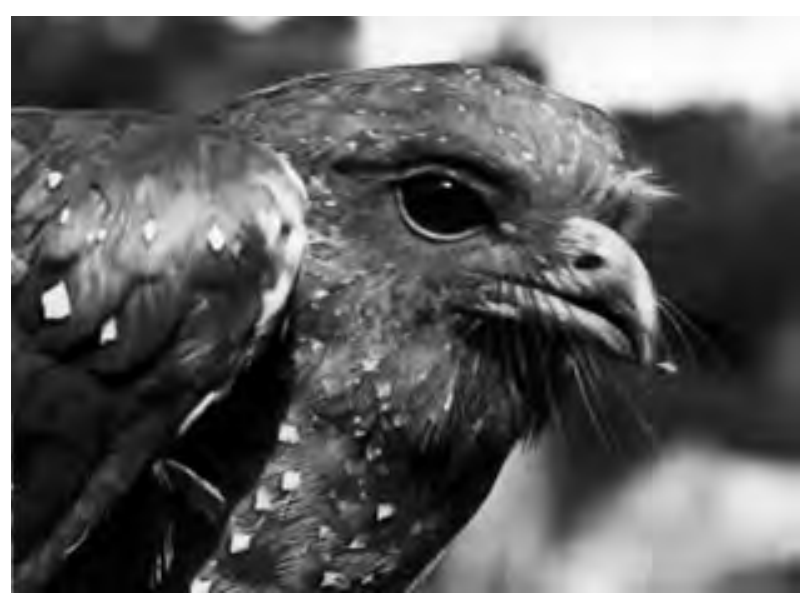

Figure 51. Steatornis caripensis.

29/02-03/03/1972. San Andrés de Cutervo, Cajamarca, 2400 m: Impressive cave at the foot of the Cordillera de Tarros. The main entrance of the cave is at the edge of the dense humid montane forest. We explored the cave at a length of 200-300 m. When we entered the cave it was filled with the clicking sound and the hoarse vociferation of hundreds of birds. Part of them were sitting on their nests, others 
were criss-crossing the cave. The nests (Fig. 52) - small platforms made of silt - are precariously placed on the walls and the ceiling of the cave. Some of the nests were dark coloured, indicating, that they were recently built. We saw no signs of breeding activity nor presence of young.
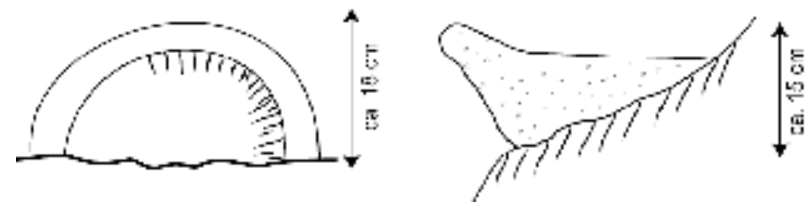

Figure 52. Nest of Steatornis caripensis: oversight and section.

Evening exodus (Fig. 53): The first birds left the cave around 7 pm:

01.03. at 19:04

02.03. at $18: 57$

03.03. at 19:00

The exodus ended at about 21:30

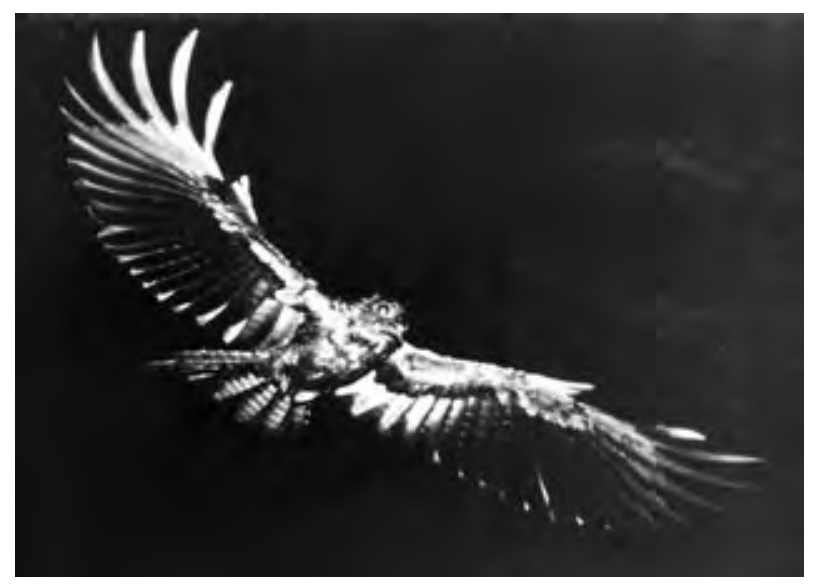

Figure 53. Steatornis caripensis leaving cave.

\section{Census:}

\begin{tabular}{|c|c|}
\hline 29.02. 19:00-19:30 & 222 ind. \\
\hline$\underline{19: 30-20: 00}$ & 226 ind. \\
\hline 19:00-20:00 & 448 ind. \\
\hline 03.03. 19:00-19:15 & 159 ind. \\
\hline$\underline{19.15-19.30}$ & 99 ind. \\
\hline $19: 00-19: 30$ & 258 ind. \\
\hline
\end{tabular}

The birds - they were clearly recognizable against the bright evening sky - left the cave in pairs or small groups of up to 6 inds. They often circled over the entrance before leaving the site definitely. They returned to the cave between 6 and $7 \mathrm{am}$. Half an hour before leaving and half an hour after returning, odd sounds emerged from the depth of the cave: hissing, shrieking, scrooping - increasing in the evening, diminishing in the morning.

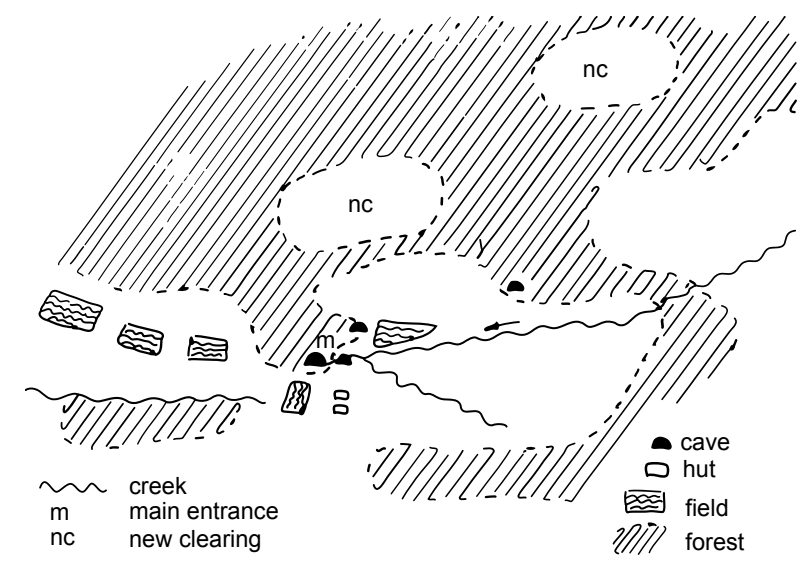

Figure 54. Location plan of the breeding cave of $S$. caripensis
How many birds live in the cave? Considering that we overlooked some birds during the count and that the exodus lasted roughly two hours, the cave accommodates well over a thousand guacharos.

\section{CAPRIMULGIDAE}

\section{Chordeiles rupestris}

25-31/071964. Juanjui, San Martín, 300 m: C. rupestris apears daily at dusk, shortly after $6 \mathrm{pm}$. They fly in extended strings downstream. Some stay behind, hunting over the Rio Huallaga.

13/01/1965. Yurimaguas, Laguna San Ango, 200 m: A flock of 100-200 inds. hunting at $11 \mathrm{am}$ in midst of dense rainfall. They gather temporarily in the canopy of an isolated tree.

23/07/1983. Huimbayóc, Rio Huallaga, San Martín, 250 m: At sunset $(6 \mathrm{pm})$ a big flock appears over the river.

06/02/1999. Moyobamba, San Martín, 850 m: Three sightings on a boat trip on Rio Mayo: Two seperate groups of about 100 inds. densely perched on the branches of driftwood. At late afternoon a group hunting over the river.

\section{Chordeiles acutipennis}

Sightings/Habitat.- Coast of Piura, Lambayeque, Ancash, Lima, Ica. Urban areas, sand dunes with Prosopis, riparian vegetation, riverbanks, totorales, fallow land

Behavior.- Hunting alone or in small groups of up to 10 inds. over plazas, around street lighting at dusk and during the night. At daytime resting on the ground (where it often goes undetected thanks to perfect camouflage) or on low branches of scrub and trees.

Breeding.- On three occ. (Apr 1964 - 04/04/1966 - 23/04/1967) I found a fully fledged young (Fig. 55) in a school yard in San Antonio, Miraflores - evidence, that $C$. acutipennis is breeding on the flat roofs of the school buildings.

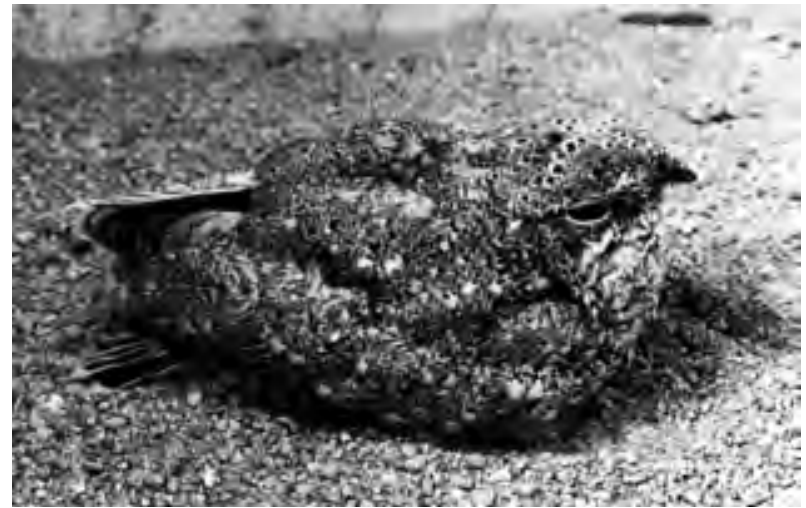

Figure 55. Fledgling of Chordeiles acutipennis

27/03/1963. International Airport, Callao: Ind. hunting undisturbed by the noise and the bustle in the waiting hall of the airport at midnight. There is plenty of prey fluttering around the numerous neonlights.

27/07/1963. Pisco, Ica: The first ind. appears at dusk (around 6 $\mathrm{pm})$. Soon there is a second and a third ind. hunting over the plaza and the adjacent buildings.

04/09/1963 - 11/03/1964. Laguna Villa, south of Lima: The first ind. appears at 17:45/18:10. Later in increasing numbers hunting over the totoral.

16/10/1963. Panamericana Sur, Hipódromo Monterrico/Lima: The apearance of $C$. acutipennis coincides with the disapearance of Pygochelidon cyanoleuca, both insect hunters.

04/01/1964. Urbanización Santa Catalina, La Victoria/Lima: Ind. calling at dawn $(05: 45)$.

11/01/1968 - 17/11/1968 - 23/11/1969 - 09/03/1971. Rivermouth of Rio Mala (Fig. 56), Lima: 

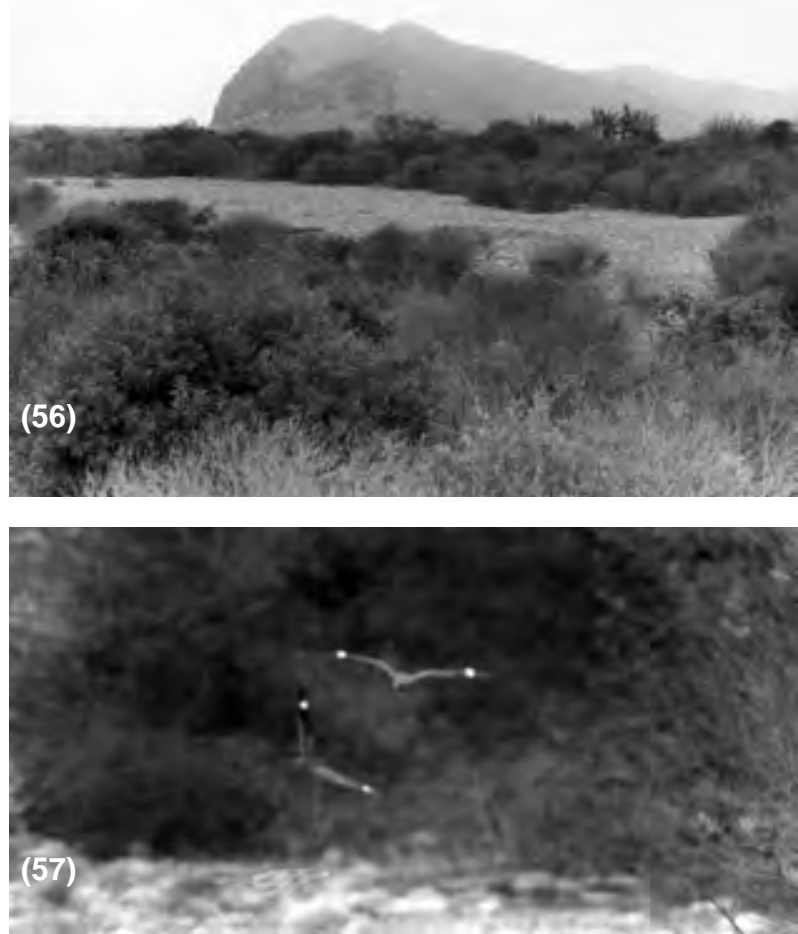

Figure 56-59. Chordeiles acutipennis. (56) Habitat, (57) in flight at dusk,

Numerous on all occ.; up to 6 inds. at the same site; hidden on sandy ground between pebbles (Fig. 59), beneath scrub or perched on low branches (Fig. 58). In late afternoon 2 or 3 inds. chasing each other in flight (Fig. 57).

Calls (recorded exclusively on 17/11/1968): During flight or on the ground. When calling on the ground, $C$. acutipennis rises its head, displaying its white throat. Song: a soft, cooing croo'croo'coorrr...; call: a chicken-like gwaa'gwa'gwaa.

15/02/1972. Miraflores/Lima: Ind. hunting at dawn (05.45) with the street lighting still switched on.

\section{Nyctidromus albicollis}

04/08/1963. Teresita (today San Francisco), Rio Apurímac, Ayacucho, $600 \mathrm{~m}$ :

Ind. netted on the beach of the river; length $23 \mathrm{~cm}$.

14-20/01/1970. Panguana Research Station, Rio Llullapichis, Huánuco, $300 \mathrm{~m}$ : Common; hunting at dusk over the stream. Song and courting display performed on sandy ground in a clearing at dusk and during the night. Song at normal level: hewthewthewt; excited: hwew'hwEEw. The song is accompanied by awkward jumps, the white tailfeathers conspicuously shining in the dark. If one gets too close to a courting male, it emits an alarmed growl.

\section{Caprimulgus longirostris}

\section{Sightings}

Lima: Rímac Valley 800-1100/3000 m, Santa Eulalia Valley $1800 / 3300$ m, Lomas de Pacta 300 m

Ayacucho: Between Puquio and Coracora in open Polylepis wood at $4000 \mathrm{~m}$

Voice.- Song: a soft, but far-reaching $p E E e w r$ emitted at irregular intervals; when flushed a sharp, repeated ooic.

The following records refer to the Quebrada California, Chosica, Lima, 800-1100 m:

$14 / 09 / 1963$. On a foggy morning at 05:30, corresponding song of two ind. at the edge of the partially irrigated area.

13/10/1963. Two breeding sites:
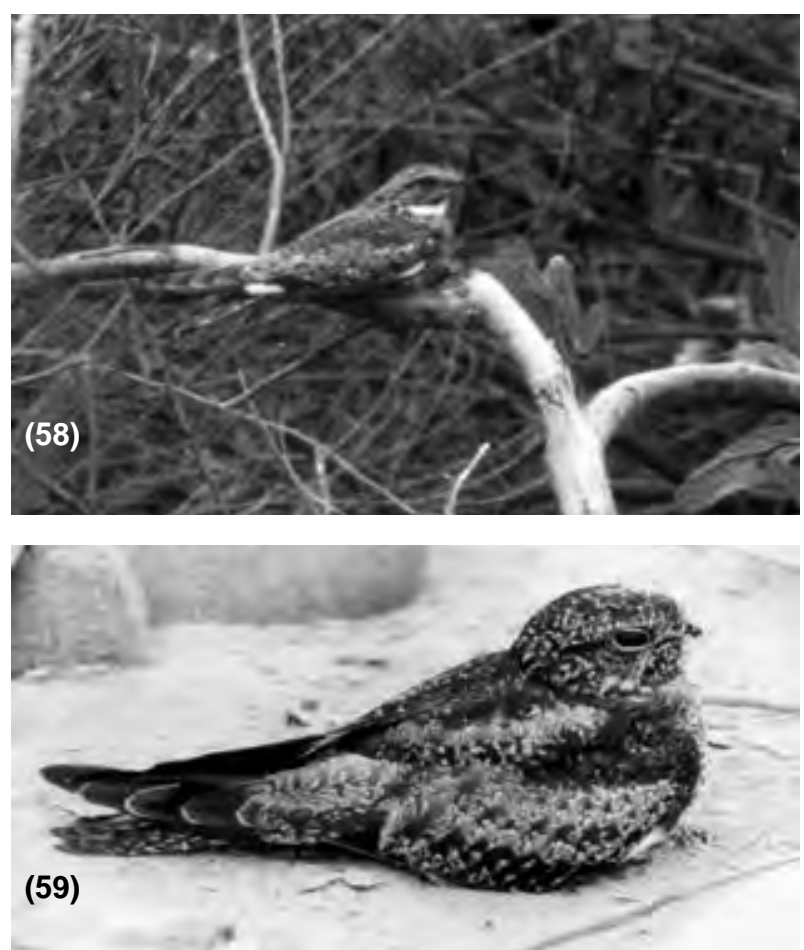

(58) roosting, (59) an individual of Chordeiles acutipennis.

Site I at $1000 \mathrm{~m}$ on a steep slope with sparse vegetation (Fig. 60). One white egg $(19.5 \times 22.5 \mathrm{~mm})$ beneath a ledge. It lays on the bare ground on a thin layer of dust in a subtly scratched out hollow $(13 \mathrm{~cm}$ in diam.). The breeding ad. flushed at short distance.

Site II at $1100 \mathrm{~m}$ at a distance of about $300 \mathrm{~m}$ from site I on flat, bare hilltop. Eggshell beneath a slightly crooked boulder. Diam. of the hollow ca. $10 \mathrm{~cm}$.

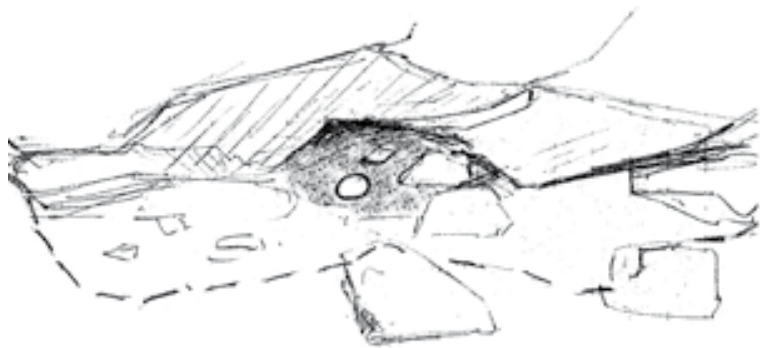

Figure 60. Nesting site of Caprimulgus longirostris (--- shaded area)

11/04/1965. Several ind. calling between 5 and 6 am. The voice emissions come form both sides of the dry quebrada. Last emission at 5:50.

05/07+04/08/1983. On each occ. two inds. flushed. They spend the daytime in the shade of rocks on the bottom of the quebrada.

\section{Hydropsalis climacocerca}

04/08/1963. Teresita (today San Francisco), Rio Apurímac, Ayacucho, $600 \mathrm{~m}$ : Male (broad white wing bands, white underparts) caught in the net on the beach of the river; length $24 \mathrm{~cm}$.

\section{APODIFORMES \\ APODIDAE}

\section{Streptoprocne rutila}

25/07-02/08/1965. Coina, Chicama Valley, La Libertad, 1500 m: Appears occ. over the Fundación Kaufmann.

06/03/1972. Cochabamba, Cajamarca, 1600 m: Large, loose group hunting temporarily over the village.

10/03/1972. Cajamarca, $2600 \mathrm{~m}$ : Hunting in large numbers over the airfield. 


\section{Streptoprocne zonaris}

\section{Sightings}

NP: La Libertad 1500/2400 m

CP: Ancash 3400 m, Lima* 100-3200 m, Pasco 2600 m, Huánuco $3100 \mathrm{~m}$

\section{SP: Cusco $3600 \mathrm{~m}$}

*Rímac/Santa Eulalia Valley at all levels from 200 (Vitarte) to 3100 $\mathrm{m}$ (San Pedro de Casta). No sightings over the urban area of Lima.

Behavior/Habitat.- Hunting solitary, in pairs and in small to large (rare) flocks over cultivated land, lomas, arid and semi-humid montane scrub; also over villages.

31/08/1963. Santa Eulalia Valley, Lima, 1600 m: Turning up several times at the sunbathed slope of the valley, hunting in company of Aeronautes andecolus and Pygochelidon cyanoleuca.

24/09/1963. Lomas de Atocongo, south of Lima, $400 \mathrm{~m}$ : For a short time big flock of about 100 inds. hunting over the ridge.

12/06/1966. San Bartolomé, Rímac Valley, 1700 m: Close group of about 20 inds. circling and soaring without wingbeat in a thermal.

\section{Chaetura pelagica}

Boreal migrant.- The spearhead of Chaetura migration reaches the urban area of Lima on the first days of Nov, reaching its climax in mid Dec and declining rapidly in the first half of Jan. Only scattered records in Lima outside main period (Oct 1x, Feb 2x, Apr 3x).

Records outside Lima: 11.02. Tambo de Mora, Ica; 21.01. Moquegua, Moquegua, $1600 \mathrm{~m}$; 17.02. Huacachina, Ica; 21.11./27.11. Canta Valley, Lima 500 m; 27.12. Huaura Valley, Lima, up to $600 \mathrm{~m}$.

The following records refer to Miraflores/Lima:

04/11/1963. 6 pm: Hundreds of Ch. pelagica swirling around the high-rise of El Pacífico before departing for their (unknown) roosting place.

Nov/Dec 1968-1973. Daily in small groups of 5-10 inds. along the tipa-lined anvenues, flying low over the tree tops. (Recorded at the same period in other dirstricts of Lima: Ciudad de Dios, S. Isidro, Jesús Maria, La Victoria, Rímac, Comas and Callao)

First half of Jan 73 Daily over school area; occ. hunting in mixed groups with Pygochelidon cyanoleuca; on one occ. permanently present from 8 to $12 \mathrm{am}$, emitting chirping sounds.

04/01/1973. Flock of 200-300 inds. forming an impressive whirl over the Centro Comercial of San Antonio.

\section{Chaetura brachyura}

15-16/02/1964. Sauce Grande, Amotape Mountains, Piura, 700 m: Hunting noisily in loose groups over deciduous forest.

13/01/1966. Matapalo, Tumbes: Hunting over Bombax forest.

\section{Aeronautes montivagus}

17-18/02/1967. Machu Picchu/Huayna Pichu, Cusco, 2400-2700 $\mathrm{m}$ : In close group over mountain top and hotel, screeching during flight.

\section{Aeronautes andecolus}

\section{Sightings}

NP: Cajamarca 2800 m (northernmost record: Jequetepeque Valley), La Libertad 1500/3300 m

CP: Ancash 100/3500 m, Lima 200-3600 m (at all levels), Huancavelica $2000-2800 \mathrm{~m}$, Ica 300-2000 m

SP: Arequipa $3400 \mathrm{~m}$, Moquegua $1400 \mathrm{~m}$

Behavior.- Occ. solitary, mostly in small or medium sized groups. 31/08/1963. Sta. Eulalia Valley, Lima, 1600 m: Large group together with Streptoprocne zonaris and Pygochelidon cyanoleuca.

15/09/1963. Zárate, Rímac Valley, Lima, 3000 m: Turns up in great numbers together with Orochelidon murina as soon as the sunshine reaches the forest. They hunt at canopy-level as well as high over the forest, attracted by big swarms of mosquitoes.

01-03/11/1963. Santa Eulalia Valley, Lima, 1800 m: Appears daily in the afternoon in company of $O$. murina, the latter hunting on a lower level, the first at medium and higher altitudes. Both disappear at dusk.

Second half of Sep 64 Ten times recorded at the same place and at the same time of the day: Below Naña, Rímac Valley, Lima, 500 m; between 5 and $6 \mathrm{pm}$. They leave shortly before sunset.

03/10/1964. Santa Eulalia Valley, Lima, 1700 m: Appears at 3 pm together with $O$. murina. Great swarms of mosquitoes over pasture land!

\section{TROCHILIDAE}

\section{Colibri coruscan}

Sightings/Behavior.- Most sightings in Lima; most frequently between 2500 an $3500 \mathrm{~m}$. Courting activity - song and flight display as described in BP - recorded from mid March to the end of July; on east slope of CP also in Feb (Huariaca, Pasco, 3000-3300 m)

05/02/1965. Casta, Santa Eulalia Valley, Lima, 3200 m: Ind. bathing in an irrigation channel, where the water flows over a slab.

12-13/06/1965. San Bartolomé-Zárate, Rímac Valley, Lima, 2000-3200 m: The most numerous hummingbird in montane scrub and humid montane forest. Courting activity from 6.15 am to dusk, including at noon.

28/07/1967. Cajatambo, Pativilca Valley, Lima, 3400-3600 m: Numerous in montane scrub. Courting activity early in the morning at a sun warmed slope. - Ind. preening and straightening its plumage after bathing in a irrigation channel (slab with shallow water).

02/08/1966. Aricapampa, Marañón Valley, La Libertad, 2400 m: Insect hunting ind. performing almost vertical leaps (3-5 $\mathrm{m}$ high), at the edge of a creek.

26/06-03/07/1971. Chiuchín, Huaura Valley, Lima, 2600-3000 m: Numerous in montane scrub. Shows a rather agressive behavior: attacks and persues repeatedly Patagona gigas and on one occ. Falco sparverius.

\section{Adelomyia melanogenys}

29/07/1965. Huacamochal, Chicama Valley, La Libertad, ca. 2000 $\mathrm{m}$ : Ind. perched on a small tree.

28/09/1971. Contumazá, Cajamarca, $2700 \mathrm{~m}$ : Ind. in a lush 4 quebrada perched on Alnus.

\section{Polyonymus caroli}

Sighted on three occ. in Zárate, Rímac Valley, Lima, 3000/3100 m:

$15 / 09 / 1963$. Ind. netted at the edge of the forest; length $11,5 \mathrm{~cm}$, bill $2,5 \mathrm{~cm}$.

$12 / 06 / 1966$. Ind. in open forest.

$23 / 03 / 1970$. Several sightings. Ind. bathing at a well at the upper fringe of the forest. After the procedure - lasting 2-3 min. - it carefully straightens its plumage, perched on a branche of a large Oreopanax.

\section{Oreotrochilus melanogaster}

(Identification of the female not based on physical characteristics but on geographical distribution; see BP)

25-26/03/1966. Chumcha, Santa Eulalia Valley, Lima: a) 3500 m: Female hunting insects over a bubbling mountain creek. She repeatedly crosses the spray. To rest, she perches on polished stones - or rather clings to them - in midstream. b) $3700 \mathrm{~m}$ : Female hunting low over the ground in montane scrub. She rests occ. on a stone. c) ca. $4500 \mathrm{~m}$ : Breeding female in a niche in a large boulder about $4 \mathrm{~m}$ above ground. The nest, a deep, thick walled cup, is $8-10 \mathrm{~cm}$ high. It consists mainly of moss, draped with lichen (Fig. 61). 


\section{Metallura phoebe}

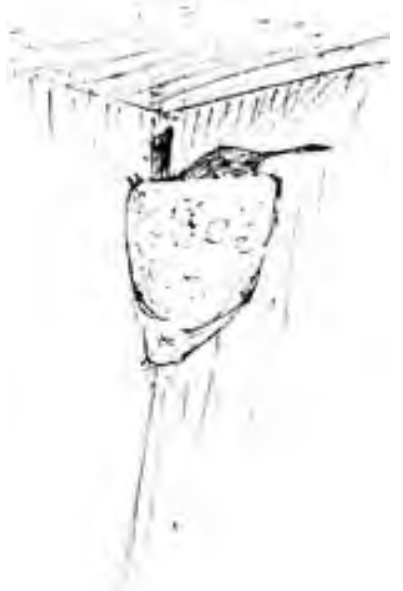

Figure 61. Oreotrochilus melanogaster breeding.

26/04/1969. Chumcha, $4100 \mathrm{~m}$ : Same scene as 25.03 .66 at $3500 \mathrm{~m}$

27/04/1969. Watershed between Sheque and Marcapomacocha, Lima/Junín, $4700 \mathrm{~m}$ : Small lagoon with cushion plants. Male hopping from plant to plant, performing short leaps to catch insects in the air.

\section{Oreotrochilus estella}

28/11/1964. Huaura Valley, Lima, 4300 m: Male perched on a scrub at the edge of a lagoon.

01/07/1966. Hacienda Moyán, Rio Chusgón, La Libertad, 3600 $\mathrm{m}$ : Male on an overgrown cliff.

19/01/1972. Ananea, Puno, $4700 \mathrm{~m}$ : Male perched on a protruding beam of the church.

04/07/1993. Near Huamachuco, La Libertad, $3200 \mathrm{~m}$ : Male in montane scrub with fields, perching in a shady grove (Fig. 62). It repeatedly leaps into the air, catching insects. Later feeding on a blooming violet-red scrub with needle-like thorns.

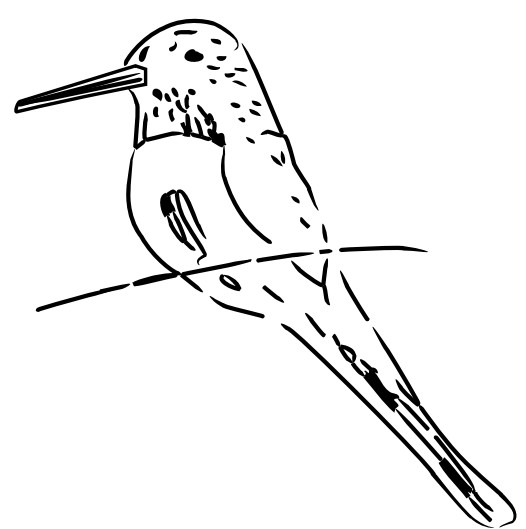

Figure 62. Oreotrochilus estella.

\section{Metallura thyriantina}

Four records $(1963,1965,1966,1970)$ in humid montane forest of Zárate, Rímac Valley, Lima, 3000 m:

$15 / 09 / 1963$. Ind. caught in the net at forest edge; length $9 \mathrm{~cm}$, bill $1,4 \mathrm{~cm}$.

$13 / 06 / 1965$. Ind. singing, perched on a bare branch in the shade of the forest: a high twitter alternating with a guttural rattle; head stretched out, throat feathers fluffed.

\section{Sightings}

NP: La Libertad $3500 \mathrm{~m}$

CP: Ancash 3400-3900 m, Huánuco 3100 m, Lima 3000-4200 m (Coastal Valleys: Pativilca 3400 m, Huaura 3100/3800 m, Canta 3400/3700 m, Rímac 3000 m, Santa Eulalia 3300-4200 m)

19/04/1964. Marcahuasi, Casta, Santa Eulalia Valley, Lima, 3900 $\mathrm{m}$ : Quite numerous on the rocky plateau especially in shrubbery within the prehispanic ruins.

27-29/11/1964. Huaura Valley, Lima, 3800 m: In light Polylepis wood; often in pairs; occ. hunting insects over a turbulent stream.

28/06/1965. Yungay-Yanganuco, Ancash, 3500-3900 m: Quite numerous in Polylepis wood along stream.

01/11/1965. Sheque-Chumcha, Santa Eulalia Valley, 3600-4200 $\mathrm{m}$ : Several sightings in montane scrub and Polylepis wood.

29/07/1966. Marcahuamachuco, La Libertad, 3500 m: Rather common in dense scrub vegetation covering the prehispanic ruins on a mountain top.

30/09/1970. Slope of Nevado Sarasara, Ayacucho, 3700 m: Ind. in scattered Polylepis wood; perched on a tree, it emits a guttural trill. It leaves its perch twice, aproaching the 'visitor'. It hovers for a moment in front of me, then returns to the perch. (Similar curiosity recorded on $\rightarrow 01 / 11 / 1965)$.

\section{Agleactis cupripennis}

25-27/03/1966. Chumcha, Santa Eulalia Valley, Lima, 3300-4300 $\mathrm{m}$ : Common in montane scrub and Polylepis wood.

29/07/1966. Huamachuco, La Libertad, 3300 m: Sightings in montane scrub with scattered fields. When feeding on a blossom, it often clings to it.

25/05/1967. Viso, Rímac Valley, Lima, 2900 m: Adult feeding young, perched on a scrub. The adult pokes its bill repeatedly into the gorge of the young.

07/07/1968. Zárate, Rímac Valley, Lima, 3000 m: Several sightings in the forest. The flight display is a kind of dancing in the air: It hovers for a moment, drops to a lower level, hovers again, turns around in full circle, raises again etc.

24/25/04/1971. Chumcha, Santa Eulalia Valley, Lima, 3600-4100 $\mathrm{m}$ : Omnipresent in Polylepis wood: perched on an outer branch of a tree or feeding on blossoms especially Phrygilanthus. Ind. netted (Fig. 63).

07/04/2003. Laguna Purhuay, Huari, Ancash, ca. 3500 m: Common in montane scrub and Alnus forest around lake. Ind. sunbathing on a branch, its back exposed to the sun, head turned aside, feathers fluffed; with hanging wings and spread out tail (Fig. 64). This attitude is interrupted 4-5 times by briefly scratching the warmed up side of the head (it is always the same side).

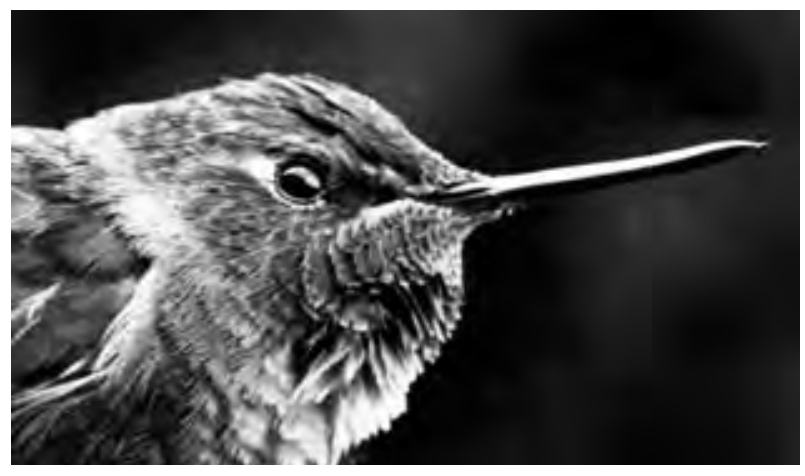

Figure 63. Agleactis cupripennis. 


\section{Myrtis fanny}

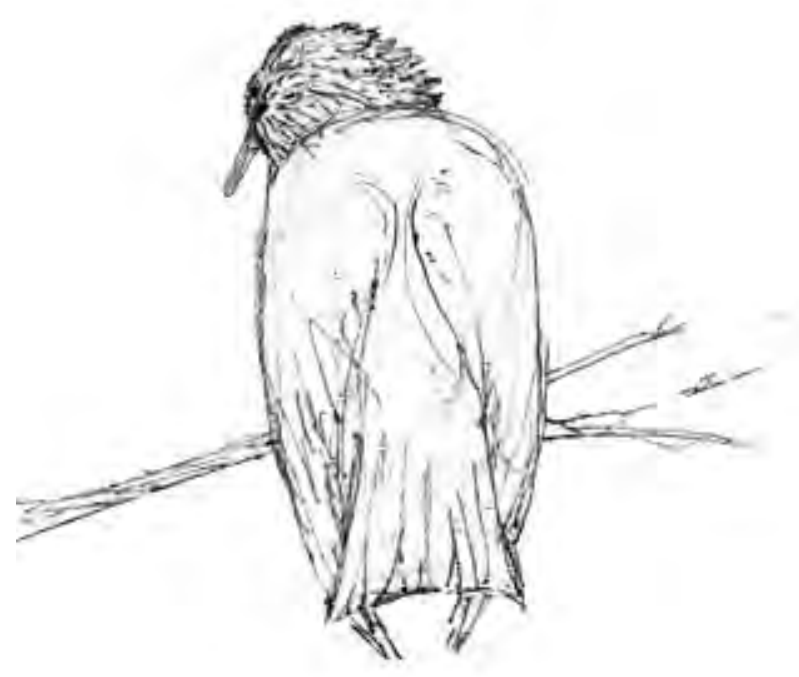

Figure 64. Agleactis cupripennis sunbathing.

\section{Boissoneaua matthewsi}

28/02/1972. San Andrés de Cutervo, Cajamarca, 2000 m: Fields and pastures with scattered forest relics: Ind. feeding on banana blossoms, occ. clinging to the inflorescence.

02/03/1972. Same place, 2400 m: Ind. feeding on Fuchsia at the edge of the humid montane forest.

\section{Patagona gigas}

\section{Sightings}

NP: Cajamarca 2400 m, La Libertad (Marañón Valley) 2400 m.

CP: Ancash 2600-3700m, Pasco 2600/3000-3300 m, Lima 1800$4100 \mathrm{~m}$ (most frequently between 2600 and $3700 \mathrm{~m}$ ).

SP: Ayacucho $3000-4000$ m, Cusco 2700/3000/3800 m, Arequipa 3000-3500 m, Puno $3800 \mathrm{~m}$.

Lowest record: San Bartolomé, Rímac Valley, Lima, 1800 m (BP $2000 \mathrm{~m})$.

Voice.- Call: a sharp qip often given in flight; song: a sputtering chatter.

28/03/1964. Surco, Rímac Valley, Lima, 2300 m: Numerous on steep slope of montane scrub. On several occ. two inds. (probably rivaling males) engage in a kind of whirl dance and pursuit flight, some times high up in the air. (Similar behavior: 02/08/1966, Aricapampa, Marańón Valley, La Libertad, 2400 m).

01/11/1965. Sheque-Chumcha, Santa Eulalia Valley, Lima, 3600$3800 \mathrm{~m}$ : Common in montane scrub. Ind. perched on a cactus, capturing insects. After each foray it returns to the same perch (four successful forays in a row).

03/12/1966. Same place, 3300-4100 m: Numerous in montane scrub; some with yellow marks (pollen) on their forheads. Ind. repeatedly flying low over a creek, dipping its bill into the water, touching the surface with its tail. - One record in Polylepis wood.

06-12/06/1967. Chiuchín, Huaura Valley, Lima, 2600-3600 m: Common in riparian vegetation, fields and montane scrub. Favoured feeding source: blooming Agavae. Often hunting insects at the edge of the stream, perched on exposed branches. Ind. makes 8-10 forays in 5 min.; max. distance $20 \mathrm{~m}$.

08/07/1979. Yauyos, Cañete Valley, Lima, 3000 m: Ind. performing acrobatic twists, while hunting insects in the air. Does not return to the perch after each foray, occ. stays hovering for some moments in search of a new prey.

06/04/2003. Baños de Chavín, Ancash, 3300 m: Ind. appears twice over torrential stream. It whirls around, hovers, bounces up and down, like in a ballet performance.

\author{
Sightings \\ NP: Cajamarca 1600/2600 m, Lambayeque $200 \mathrm{~m}$. \\ CP: Lima 100-3600 m.
}

Highest record: Huaura Valley, Lima, 3600 m (BP 3200 m).

21/07/1963. Santa Eulalia Valley, Lima, 1600 m: Up to 4 inds. simultaneously hunting insects over a shallow pond formed by the stream. When they need a rest - and they often do - they perch on exposed branches close to the water. They don't take any notice of each other.

01/09/1963. Urbanización California, Chosica, Rímac Valley, Lima, $800 \mathrm{~m}$ : Male performing flight display, a kind of pendular dance in front of a perched female.

13/10/1963. Same place: A dozen of $M$. fanny buzzing around blooming Euclayptus trees, sometimes engaging in whirl dances or pursuit flights.

19/10/1963. Lomas de Lachay, $70 \mathrm{~km}$ north of Lima, $400 \mathrm{~m}$ : Very numerous on a cold, foggy day. Excellent food supply in lush herbal vegetation with a high percentage of Lamiaceae. Up to 6 inds. perched on small trees and Agavae.

\section{Rhodopis vesper}

\section{Sightings \\ CP: Lima 0-500/900/1600-2600 m \\ SP: Ica $200 \mathrm{~m}$, Moquegua $1500 \mathrm{~m}$}

Habitat: Regularly in gardens of La Victoria/Lima and Miraflores/ Lima, also in riparian vegetation, arid and semi-humid montane scrub, lomas.

Behavior/Voice: Feeding on a great variety of blossoms; only two records hunting insects. Emits a guttural tserrr,tserr, while moving from blossom to blossom.

Mid Sep 1966. Chancay Valley, Lima, 500 m: 2 inds. circling and hovering around blooming Salix, probably in search of insects.

Mid Oct 1966. La Victoria/Lima: Male and female feeding daily on Hibiscus ( but never at the same time); on one occ. $R$. vesper is chased away by Troglodytes aedon.

31/01/1972. Moquegua, Moquegua, 1500 m: 2 inds. in hotel garden; male feeding on banana blossoms, female on Hibiscus, piercing the flower from the side.

16/09/1972. Punta Hermosa, $45 \mathrm{~km}$ south of Lima: Several inds. in a patch of vegetation in a dry valley, where they feed on numerous trumpet- and cone-shaped blossoms.

04/08/1983. Urbanización California, Chosica, Rímac Valley, 900 $\mathrm{m}$ : Pair in dry quebrada feeding on a flowering columnar cactus. Later hovering around a non-blooming specimen, prossibly searching for ants.

\section{Thaumastura cora}

Sightings.- Lima, Rímac Valley: 0/100/800/2000-2800 m; regularly in gardens of Miraflores/Lima and Urbanización California, Chosica, Lima. Only one record outside Lima: Casma Valley, Ancash, 1300 m.

Behavior/Voice.- Males often engage in rivalries and pursuit flights emitting sharp calls $(t s i c)$ or an excited chatter. If they get very close, they spread out their long tail feathers $\left(90^{\circ}\right.$ and more). Song is given from a perch and lasts several seconds: a hurried, squeezed, intermittent chatter. Additional sounds emitted during flight: tsi'tseretse or qsee'qseéqsi'dede.

01/05/1968. Outskirts of Miraflores/Lima: Meeting on two young Salix at the edge of a cotton field: Male settles on one of the trees. A newcomer provokes him. They engage in a short aerial contest. Needing a rest, each chooses its own branch on a seperate tree. That's when a third male shows up. He tries in vain to engage the two in another contest. For a while, the three remain perched at a safe distance from 
each other. Occ. they communicate with a twitter: sitrere,sitrere, their throat feathers glittering in the evening sun. Afterward, two of them leave the site, pursuing each other. The third moves on to a neighbouring irrigation channel, where he starts insect hunting in a jerky criss-cross flight.

Mid of Oct to end of Nov 1969. Miraflores/Lima: Male appears regularly in our garden

09/11/1969. Same place: Male feeding on Coleus. In 1 min it visits 122 of the tiny blue blossoms; that's an average of two blossoms per second! When feeding on Tropaeolum, it does not penetrate the blossom from the front, but from the side.

Second half of Feb 1972 Same place: Male sings daily in our garden, perched on a bare branch of an Eucalyptus tree.

13/3/1972. Same place: Pair whirling the whole day long around Eucalyptus, chattering in flight. Regularly heard and seen during the following week; occ. 3 and in one oportunity 4 inds. pursuing each other.

\section{Campylopterus largipennis}

28/01/1970. Research Station Panguana, Rio Llullapichis, Huánuco, $300 \mathrm{~m}$ : Ind. netted at forest edge; length $14 \mathrm{~cm}$, bill 2,6 cm

02/07/1972. San Ramón, Chanchamayo Valley, Huánuco, 800 m: Ind. at forest edge.

\section{Myrmia micrura}

14-15/02/1964. Hacienda San Jacinto, Piura: Ind. repeatedly perched on a dwarf palm within reach of a sprinkler.

\section{Amazilia amazilia}

Sightings.- Coast from Piura to Ica, up to $800 \mathrm{~m}$; higher elevations: Cajamarca 1600 m (east slope), La Libertad 1500 m (west slope).

\section{Most records in gardens and parks of Miraflores/Lima.}

Voice.- Call (often given in flight): a series of sharp whistles, like tsee'tsee'tsuc'tsuc. Song consists of an intense, sustained chatter (wi'tse'ge'ge) and a guttural trill (trrut,trrut), emitted from a perch, often a bare branch of a tree or a bush, occ. from a tree top. Attitude: With bill slightly opened and aimed upward, the throat feathers intermittently raised, it turns its head constantly from one side to the other.

Courting/Breeding.- Miraflores/Lima: Judging from the song activity, there seems to be two reproduction periods: one from February to April, the other from July to October.

Oct. 1963. Miraflores/Lima: Ind. hunting insects by snatching them from underneath the leaves of a tree, a method, that I have not recorded since.

26/07 - 01/08/1965. Coina, Chicama Valley, La Libertad, 1500 $\mathrm{m}$ : Common in montane scrub and orchards around the Fundación Kaufmann. Nest-building and breeding on a Thuja tree about 3 $\mathrm{m}$ above ground. The neatly done, cup-like nest is placed on a thin branch, that serves as a precarious platform (Fig. 65/66). It consists mainly of fine, vegetal fibers; the outside is camouflaged with moss and lichen. Measures: Outer diam. $4 \mathrm{~cm}$, inner diam. $2,5 \mathrm{~cm}$, height $3 \mathrm{~cm}$. Nest-building: Ind. arrives with nesting material. It settles in the almost finished nest and begins to reinforce the rim and the wall by rapidly moving its bill up and down, resembling an old-fashioned sewing machine. Before leaving again, it carries out a full turn, still sitting in the nest, its body vibrating (possibly to consolidate the nest and give it its final form). After completing the nest (27/08), A. amazilia does not show up for four days. On 01/08. I found a clutch of 2 white eggs. One of the ad. begins to breed immediately (Observation discontinued).

26-28/02/1967. Miraflores/Lima: Ind. singing in our garden on three consecutive days between 7.00 and $8.30 \mathrm{pm}$ (on one occ. also at $4.00 \mathrm{pm}$ ) always using the same perch.

22/08/1967. Same place: Ind. feeding on Hibiscus (with curled up blossom). To reach the nectar, it makes use of holes at the base of the blossoms, that have been worked out primarily by $\rightarrow$ Sporophila simplex.
01/05/1968. Same place: Ind. bathing in an irrigation channel bordering a cotton field. Its vigorous movements make the water drops fly around.

July 1970. Same place: Despite an extraordinary damp winter, ind. sings regularly on top of Eucalyptus, mostly around midday.

12/08/1970. Same place: Ind. approaches an abandoned nest of Carduelis magellanica on a Casuarina. Poking into the nest, it extracts a sizable batch of cotton and flies away with it.

November 1970. Same place: Ind. often foraging on the blue blossoms of a Salvia. Occ. it grabs hold of a blossom, but mostly moves hurriedly from one blossom to the next. It manages to visit 27 blossoms in $40 \mathrm{sec}$.

April 1971. Same place: Song given regularly between 6.00 and $7.00 \mathrm{am}$.

\section{4-13/02/1972. Same place: Ind. sings daily on Eucalyptus.}

09-14/07/1976. Urbanización California, Chosica, Rímac Valley, Lima, 800 m: Numerous; feeding on Lantana hedges, presently one of the few blooming plants. They pause only a fraction of a second at each of the tiny blossoms.

End of July 1988 Same place: Daily in the garden and the scrub covered neighborhood, where $A$. amazila favors a $2 \mathrm{~m}$ high Lamiaceae with orange-red blossoms. A feeding ind. does not tolerate others, that try to feed at the same plant. Frequent pursuit flights are the result.

29/03/2003. Pariacoto, Casma Valley, Ancash, 1200-1400 m: Common in orchards and river edge vegetation. Ind. passes low over quiet flowing creek, touching the surface of the water or slightly plunging into it; then it disappears for a short time in the riparian thicket. The procedure is repeated $4-5$ times.

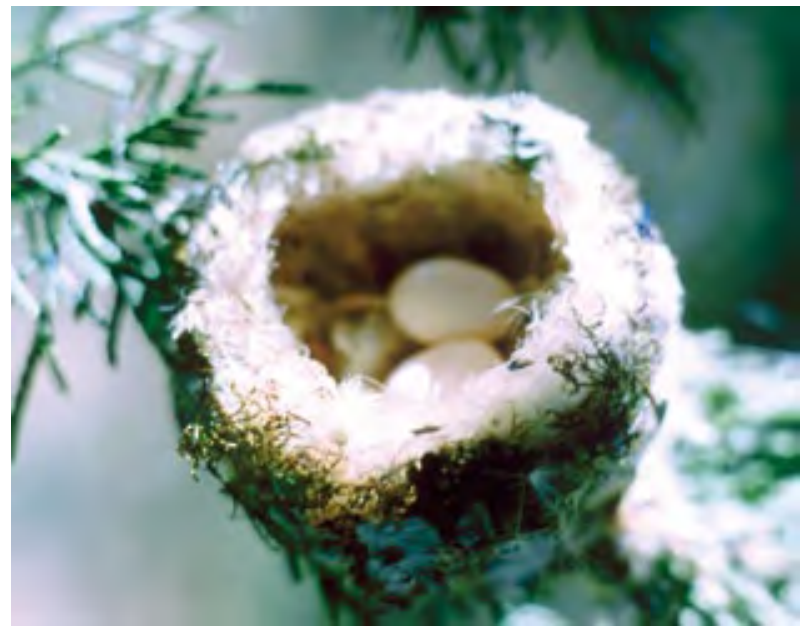

Figure 65. Amazila amazila: nest with clutch.

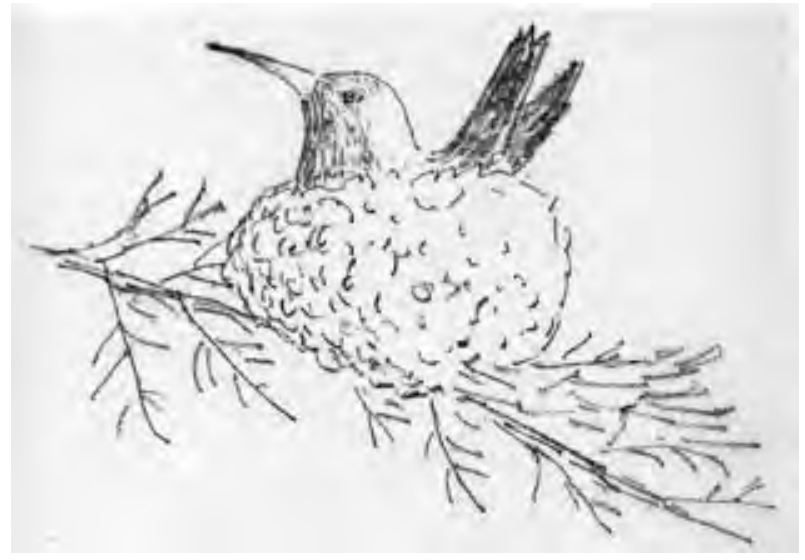

Figure 66. Amazila amazila: breeding. 


\section{Amazilia franciae}

08/07/1993. Chagual, Rio Marańón, La Libertad, 1300 m: Ind. perched on a lower branch of a tree, hunting insects; occ. foraging on Passiflora and a climber with greenish-yellow blossoms. It returns each time to the same perch.

11/07/1993. Zarumilla/Pataz, La Libertad, $2700 \mathrm{~m}$ : Feeding on Cactus, Pitcairnia, Eucalyptus and a climbing Leguminosae.

\section{Coracilformes \\ AlCEDINIDAE}

\section{Megaceryle torquata}

\section{Sightings}

Coast: Tumbes, Piura, Lambayeque, La Libertad, Lima.

Amazonia: Loreto, San Martín, Huánuco, Ucayali, Madre de Dios.

07/01/1966. Mouth of Rio Jequetepeque, La Libertad: Ind. fishing in brackwater lagoon. Also seen hovering over salt water near the beach.

09/03/1971. Mouth of Rio Mala, Lima (only record in the Department of Lima): Appears on three occ. over the lagoon bordered with Typha, hovering about $4 \mathrm{~m}$ above the water; occ. calling trac'trac'trac.

29/01/1973. Rio Utiquinilla, abaou $50 \mathrm{~km}$ northeast of Pucallpa, Ucayali, $200 \mathrm{~m}$ : Common; mostly perched at the edge of streams and oxbow lakes; also skimming low over the water, grabbing fish, that venture too close to the surface.

\section{Chloroceryle americana}

\section{Sightings}

NP: Lambayeque Coast, La Libertad Coast/300/500 m

CP: Lima: Lurin Valley 100/200/500/600/900/1100/1400/1500/ 1700 m, Chancay Valley 500 m, Mala Valley sealevel/200 m, Cañete Valley $400 \mathrm{~m}$.

Behavior.- Perched along streams and irrigation channels on branches above ponds or slow flowing water, rarely higher than $2 \mathrm{~m}$; also on stones in midstream, on roots in the riverbank; on one occ. on a telephone wire.

02/06/1963. Lurin Valley, Lima, $200 \mathrm{~m}$ : Two seperate ind. in flight. The clear stream is teaming with small fish. Regurgitated remains of prey on a flat stone.

13/06/1963. Lurin Valley, Lima, 500 m: Ind. in flight; perch in dense vegetation at the edge of the stream: the horizontal branch is marked with droppings; underneath fishbones and scales.

22-23/06/1963. Lurin Valley, Lima, 600 m: Breeding site: Two tunnels in a vertical clay wall bordering the stream, one occupied (Fig. 68 ) the other unused; three additional unfinished tunnels distributed at a length of about $15 \mathrm{~m}, 1-1,5 \mathrm{~m}$ above the stream. An old tunnel, partially destroyed by a landslide, contains eggshells, fishbones and lots of crawfish leftovers. Feeding activity between 7.00 and $8.00 \mathrm{am}$ : Ad. leaves the tunnel, its partner approaches the site, its bill charged with food (probably small crawfish). Aware of my presence, it approaches the site reluctantly, finally disappears in the tunnel.- Male (Fig. 67+69) and female caught in the net.

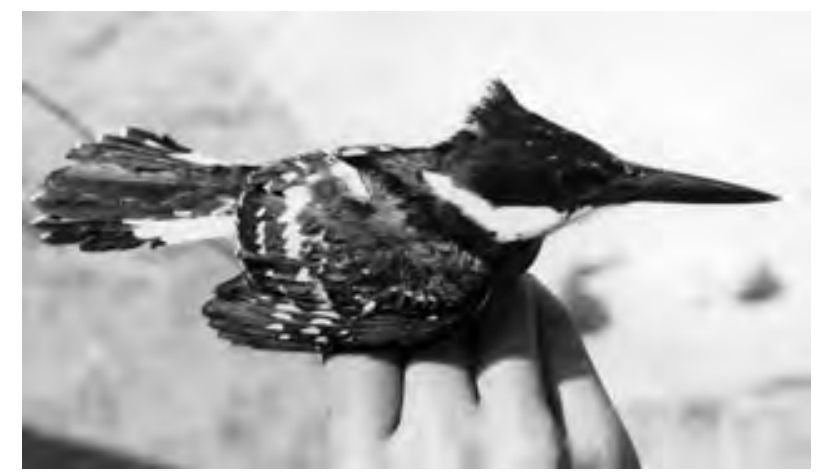

Figure 67. Male of Chloroceryle americana.

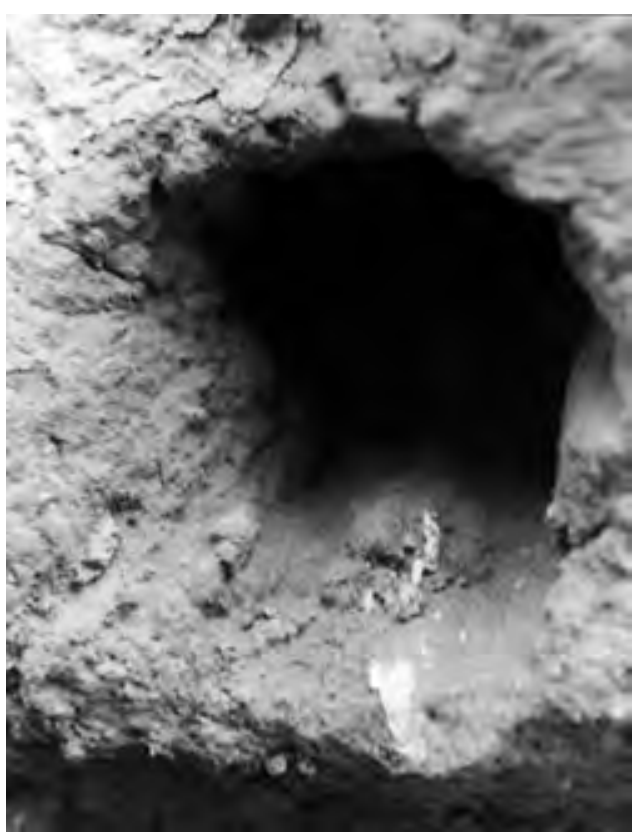

Figure 68. Chloroceryle americana: entrance of breeding tunnel.
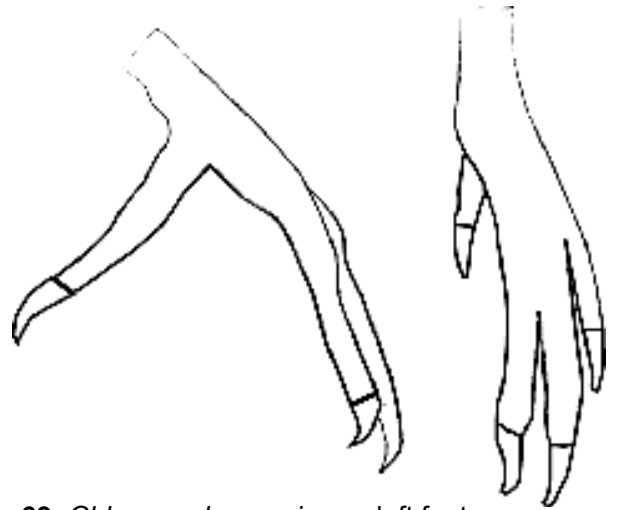

Figure 69. Chloroceryle americana: left foot.

24/10/1964. Chancay Valley, Lima, 500 m: 2 inds. along irrigation channel, pursuing each other, emitting sharp whistles.

19/01/1967. Mouth of Rio Mala, Lima: At a length of $2 \mathrm{~km}$ at least 2 pairs. Ind. darts vertically from its perch in pursuit of a prey. Shortly afterward the same ind. flies low over the pond, barely touching the surface, when catching fish.

17/11/1968. Same place: Pair perched on a bush at the edge of the stream. One of them emits a guttural call trc'trctrc.

\section{MOMOTIDAE}

\section{Momotus momota}

16/02/1964. Sauce Grande, Amotape Mountains, Piura, 800 m: 2 seperate inds. in deciduous forest.

\section{Galbuliformes \\ GaLbulidAE}

\section{Galbalcyrhynchus leucotis}

02/10/1972. Laguna San Ango, Yurimaguas, Loreto, 200 m: 4 inds. perched quietly on a tree at the edge of a clearing. One of them returns from a hunting foray with an insect. Before swallowing it, it turns and shifts the prey circuitously in its long bill.

27/01 - 02/02/1973. Yarinacocha, Pucallpa, Ucayali, 200 m: (BP maintains, that Pucallpa belongs to the distribution area of Galbalcyrhynchus purusianus, conceding that the two species approach one another along central Rio Ucayali.) Rather common; it favors forest edges along rivers and lakes. Mostly 2, 3 or 4 inds. together, perched on a branch. In contrast to the motionless body, the head is constantly 
turning around, looking for flying insects. One ind. arrives with a dragonfly, another with a large beetle. To crash the rigid carapace, it bangs its bill several times against the perch until it manages to swallow the prey. Contact call: tsee'tsee-turr'turr, alarm call: qYap'qYap.

\section{Galbula cyanescens}

28/07/1964. Juanjuy, San Martin, 400 m: Ind. perched in a shady quebrada.

18/01/1970. Research Station Panguana, Rio Lluallapichis, Huánuco, $300 \mathrm{~m}$ : Ind. perched at the edge of the forest on an exposed branch. It moves its head up and down or shifts it from one side to the other. It performs several forays to catch flying insects. On one occ. it returns with a large butterfly (Fig. 70). Twisting and turning it in its bill, one of the wings breaks off, then the other. While the wings are tumbling down slowly, the body of the butterfly is falling fast. But before it reaches the ground, G. cyanescens catches it in the air. It returns to the perch to swallow it in a swoop.

17/07/1976. Between Puente Inambari and Quincemil, Cusco, ca. $500 \mathrm{~m}$ : Ind. returns with an insect to its perch in the forest.

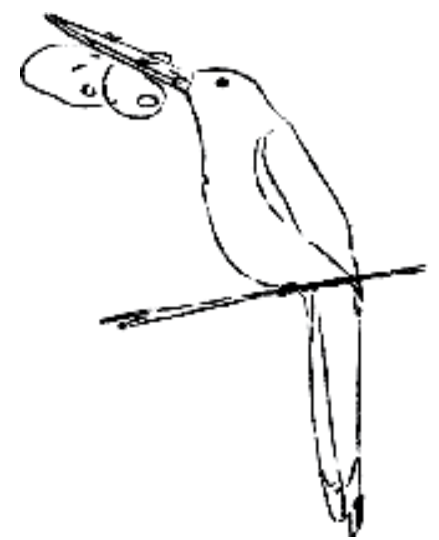

Figure 70. Galbula cyanescens with prey.

\section{BUCCONIDAE}

\section{Notharchus hyperrhynchus}

24/03/1903. Posada Amazónica (observation tower), Rio Tambopata, Madre de Dios: Pair in canopy perched on a dry branch.

\section{Monasa nigrifrons}

28/07/1964. Juanjuy, San Martín, 300 m: Several ind. on a bush in dense vegetation at the edge of a forest creek.

14-20/01/1970. Research Station Panguana, Rio Llullapichis, Huánuco, $300 \mathrm{~m}$ : Common; they perch in trees individually or in small groups, motionless. Lively and sustained song given in chorus. As one ind. begins, others join in. The song begins slowly and quietly, becoming louder and faster (up to 15 notes in $5 \mathrm{sec}$ ), at the climax, the chatter turns into a trill.

01-06/10/1972. Laguna San Ango, Yurimaguas, Loreto, $200 \mathrm{~m}$ : Quite numerous; hunting insects in the shady part of the forest as well as in clearings; also perched on solitary trees; often several ind. together. -2 inds. perched very closely on a mighty Ficus tree at the edge of the lake. Song: an uninterrupted chatter given in duet.

\section{Chelidoptera tenebrosa}

25-31/07/1964. Juanjuy, San Martín, 300 m: Sporadic; in clearings and at river edge. Breeding tunnel at river bank: Pair arriving and departing.

31/01/1970. Puerto Inca, Rio Pachitea, Huánuco, 300 m: On a limited trajectory of the river rather numerous. 2 or 3 inds. perched conspicuously on stakes or dead trees, hunting insects.

03/07/1972. La Merced, Chanchamayo Valley, Junín, 800 m: Ind. hunting insects from a high pole.
05/10/1972. Laguna San Ango, Yurimaguas, Loreto, 200 m: Ind. perched on the dead top of a tree.

\section{PICIFORMES \\ CAPITONIDAE}

\section{Capito aurovirens}

24/01 - 02/02/1973. Yarinacocha, Pucallpa, Ucayali, 200 m: Several sightings in humid forest. Calling ind. perched on a branch, twitching its wings: crrrew'crrew. - Chorus song given by a group perched on a tree: One ind. begins, immediately followed by 2 or 3 others. The metronome like notes resemble the croaking of frogs. A sequence lasts 10-15 sec, then the group falls silent for quite a while.

\section{Capito auratus}

16/01/1970. Research Station Panguana, Rio Llullapichis, Huánuco, $300 \mathrm{~m}$ : Ind. at the edge of the forest capturing insects by climbing skillfully through branches and lianas.

\section{Eubucco richardson}

16/01/1970. Research Station Panguana, Llullapichis, Hánuco, $300 \mathrm{~m}$ : Ind. at the edge of the forest, hunting insects in dense foliage.

\section{Eubucco versicolor}

21/09/1968. Yaupi, Rio Paucartambo, Pasco, ca. 2000 m: 2 or 3 inds. in an isolated group of trees at the edge of the humid montane forest, calling simultaneously: a soft purrr. One ind. collected by a local.

\section{RAMPHASTIDAE}

\section{Ramphastos tucanus}

14-20/01/1970. Research Station Panguana, Rio Llullapichis, Huánuco, $300 \mathrm{~m}$ : Regularly near the station perched on high trees. Distinctive song given individually or in duet. It consists of alternating high (qewc) and low notes (qyac), both being repeated in an irregular manner. The performing ind. raises its bill in accordance with the high notes, while accompanying the low ones by turning its head from one side to the other.

\section{Aulacorhynchus coeruleicinctis}

21/09/1968. Rio Paucartambo, Pasco, 2300 m: Ind. on a steep slope in a patch of humid montane forest.

\section{Pteroglossus castanotis}

24/01/1970. Fundo Helvetia, Tingo Maria, Huánuco, 800 m: Ind. perched on a tree in a coffee plantation (Fig. 71).

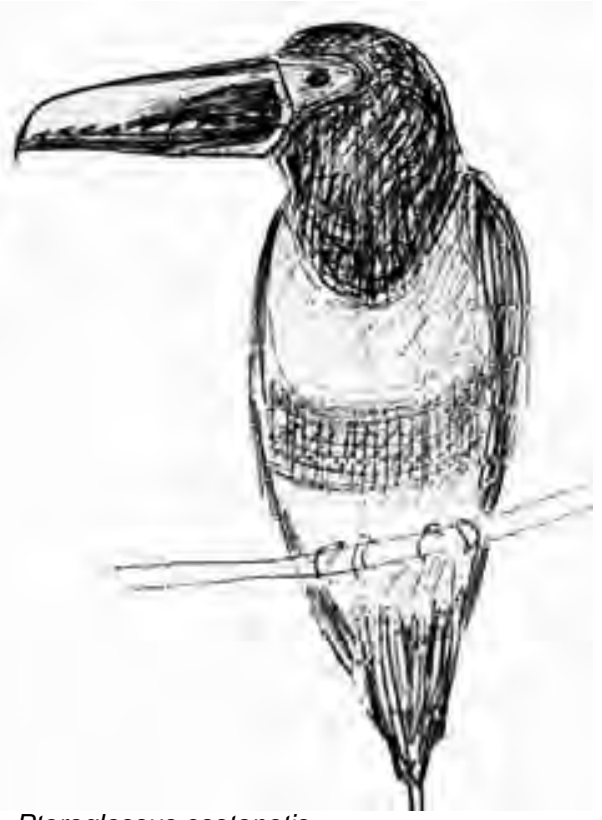

Figure 71. Pteroglossus castanotis. 
05/07/1972. San Ramón, Chanchamayo Valley, Junín, 800 m: 3 inds. in a group of trees surrounded by second growth. One of them is hopping from branch to branch of a Cecropia, probably collecting ants.

\section{Pteroglossus beauharnaesii}

24/03/2003. Posada Amazónica (observation tower), Rio Tambopata, Madre de Dios: Group of several ind. in canopy of humid forest.

\section{PICIDAE}

\section{Picumnus sclateri}

16/02/1964. Sauce Grande, Amotape Mountains, Piura, 700-800 $\mathrm{m}$ : Several sightings of foraging pairs in deciduous forest.

\section{Picumnus dorbignyanus}

20/09/1968. Rio Paucartambo, Pasco, 2000 m: Ind. perched on a small tree in relic of humid montane forest.

\section{Melanerpes cruentatus}

30/06/1969. Mazamari near Satipo, Junín, 800 m: Several inds. on a cleared slope on isolated dead trunks, often 2 or 3 inds. together. Call: (trrr) gra'gra'gra.

13/01/1970. Hacienda Helvetia, Tingo Maria, Huánuco, 800 m: Common; gregarious; on dead trunks in coffee plantation. 3 or 4 inds. together on the same trunk, that features many nest-holes. Two ind. (pair?) have choosen a special hole for inspection. The group is quite busy, occ. emitting their resounding call. - Ind. pecking at the blossoms of Cecropia.

23/01/1970. Between Divisoria and Tingo Maria, Huánuco, 1400 $\mathrm{m}$ : Ind. on a tree in tea plantation.

03/07/1972. La Merced, Chanchamayo Valley, Junín, 1000 m: Group in second growth wandering from tree to tree, occ. calling. When foraging, they do not only climb upwards, backwards and sidewise but also head down.

07/02/1999. Moyobamba, San Martín, 800 m: Ind. on top of a dead tree, persistently preening its plumage.

\section{Veniliornis passerinus}

27-28/07/1964. Juanjuy, San Martín, 300 m: Ind. on a river island, drumming on a thin, dry trunk. It is driven away by Chrysoptilus punctigula. Another ind. on a tree in cultivated plot.

\section{Veniliornis fumigatus}

30/07/1965. Between Hacienda Chuqizongo and Huaranchal, Chicama Valley, La Libertad, 1800 m: Ind. in montane scrub with scattered trees.

31/07/1976. Baños Yumagual, Jequetepeque Valley, Cajamarca, $2800 \mathrm{~m}$ : Ind. on lichen-covered tree situated in a relic of humid montane forest.

10-11/07/1993. Pataz, Marañón Valley, La Libertad, 2800 m: Ind. in quebrada with lush vegetation. Another ind. inspecting a breeding hole in a dead trunk of Agave. The trunk (about $5 \mathrm{~m}$ high with broken off top) features 5 holes, all on the same side (towards the valley); diam. of the entrances ca. $4 \mathrm{~cm}$.

\section{Colaptes atricollis}

\section{Sightings}

NP: Lambayeque 600 m; La Libertad, Marañón Valley, 1200/2400 m.

CP: Lima sealevel/1300-3100 m*.

SP: Arequipa 2200/3400 m.

* Coastal valleys: Huaura 2600/2700 m, Canta 1600 m, Rímacl Santa Eulalia 1700-3100 m, Lurin 1700/2400 m, Mala sealevel, Cañete $1300 \mathrm{~m}$

Vertical distribution acording to BP $600-2800 \mathrm{~m}$; differing records:
Mouth of Rio Mala, Lima, sea level; Casta, Santa Eulalia Valley, Lima, 3100 m; Pampamarca, Cotahuasi Valley, Arequipa, 3400 m.

Behavior/Voice.- Solitary or in pairs; foraging on trunks and branches of trees; also on cacti and Agave; occ. on the ground. More often heard than seen. Resounding song: a slightly descending gu'gu'gu... Call: qyac or $y E E a p$.

01-03/11/1964. Santa Eulalia Valley, Lima, 1800 m: Heard and seen in cultivated land with pastures, orchards and riparian vegetation with old Schinus trees. Male caught in the net (Fig. 72).

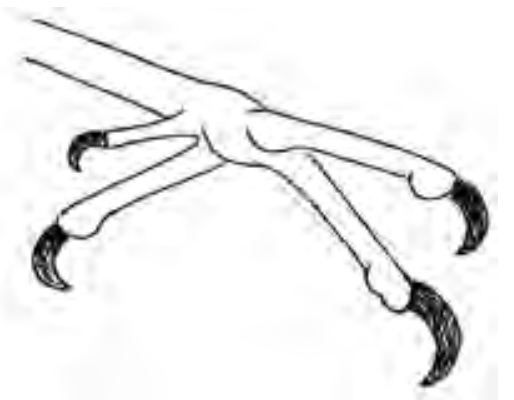

Figure 72. Colaptes atricollis: left foot.

03/08/1966. Aricapampa, Marañón Valley, La Libertad, 2400 m: Ind. on the ground beside a small creek, probing the humid ground.

17/11/1968. Mouth of Rio Mala, Lima: Pair engaged in courting activity: First perched on a large Salix, then on Tessaria. They approach each other up to $30 \mathrm{~cm}$, calling intermittently, while performing a metronome-like movement with their body (Fig. 73).

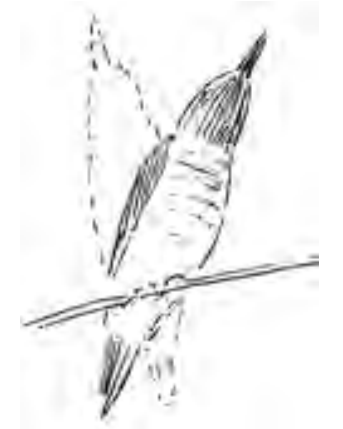

Figure 73. Colaptes atricollis: courting display.

05/04/1969. Lurin Valley, Lima, 1700 m: Fallen Alnus trunk in riparian wood with breeding hole; originally about $5 \mathrm{~m}$ above ground (Fig. 74).

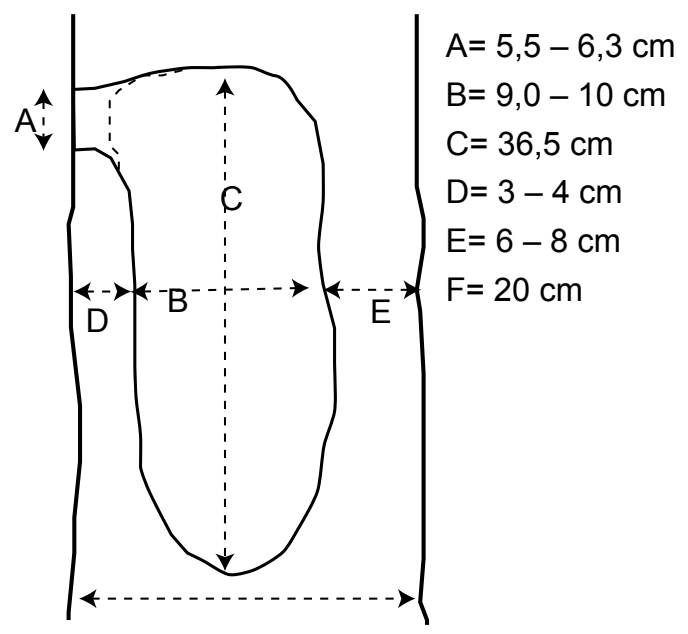

Figure 74. Colaptes atricollis: section through breeding hole. 
19/04/1970. Same place: 4 breeding holes in a live Alnus (Fig. 75). The holes are placed within the dead core of the tree. The lowest one is about $2 \mathrm{~m}$ above ground; distance between the entrances about 50 $\mathrm{cm}$; diam. of the holes 5-6 cm, horizontal depth $10-11 \mathrm{~cm}$.

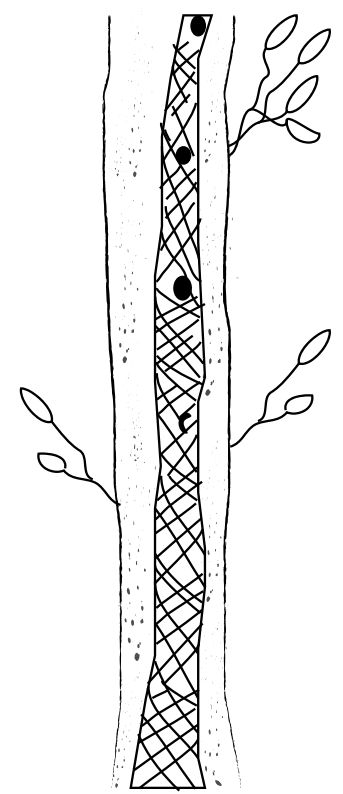

Figure 75. Colaptes atricollis: Alnus with breeding holes.

\section{Colaptes punctigula}

27/07/1964. Juanjuy, San Martín, 300 m: Ind. on a river island chases away a drumming Veniliornis passerinus.

\section{Colaptes rupicola}

\section{Sightings}

NP: Amazonas 2400 m, Cajamarca 3300-3800 m, La Libertad $1700 / 2500 / 3000-3800 \mathrm{~m}$

CP: Ancash 3500-4200 m, Lima 2800-4200 m, Pasco 3300-3400 m, Junín 3500/4100-4500 m, Huancavelica 3500/4300 m, Ayacucho $2900 \mathrm{~m}$

SP: Ayacucho 3000-3800 m, Cusco 3000-3600 m, Puno 3900-4300 m, Arequipa 3400/4000 m

Lower limit of distribution according to BP $2700 \mathrm{~m}$. Records below that level: Hacienda Chuquizongo, Chicama Valley, La Libertad 1700 m; Chachapoyas, Amazonas, $\mathbf{2 4 0 0}$ m; Hacienda Cochabamba, between Huamachuco and Rio Marańón, La Libertad, 2500 m.

Habitat.- Puna and Paramo grassland, montane scrub, rocky plateaus and rocky outcrops, Polylepis wood, pastures, cultivated plots, villages, prehispanic ruins with scrub vegetation.

Behavior/Voice.- Mostly on the ground; in pairs or small groups; often perched on stones, rocks or walls; also on roofs, telephone poles, Eucalyptus and other trees; group display with nearly vertically raised bill; resounding calls, emitted single or in series; guttural trill.

01/10/1970. Laguna Parinacochas, foot of Nevado Sarasara, Ayacucho, 3400 m: Ind. harassing several times a Falco femoralis, perched on a cliff. After the unsuccessful attacks, it settles only a few meters away from the 'intruder'.

29/08/1971. Pisco Valley, Quebrada de Huaytará, Huancavelica, $3800 \mathrm{~m}: 3$ inds. engaged in group display on a mighty boulder.

20-27/02/1972. Putina-Muñani, Puno, 3900-4000 m: Common in Puna grassland; also in villages. Putina: Ind. calling on top of the church tower.

18/11/1972. Between Baños and Sta. Cruz, Chancay Valley, Lima, 3800 m: Pair leaves nest-hole at street side.
14/07/1988. Achoma, Colca Valley, Arequipa, 3400 m: Pair on pasture among numerous Vanellus resplendens.

05/07/1993. Huamachuco, La Libertad, $3000 \mathrm{~m}$ : Numerous in the ruins of Viracochapampa, which are partially covered by dense vegetation. The conspicuous birds perch on the crumbling stonewalls, on trees and bushes. The resounding calls are ubiquitous: A series of similar notes: qyac'ac, yac'yac'qyac, intensified in flight.

19/01/1999. Llullapuquio, Jequtepeque Valley, Cajamarca, 3300$3600 \mathrm{~m}$ : Occ. in Paramo and pasture land. 3 inds. engaged in group display on a grass-roofed hut. - A perforated wall of an uninhabited adobe construction is visitited every once in a while by $C$. rupicola. The visiting bird may stay for several minutes. It pecks randomly at the wall and inspects occ. one of the many holes (ca. 25). If another ind. arrives, the first generally leaves the site. Some inds. are gathering on a nearby Sambucus.

18/03/2003. Chincheros, Cusco, 3600 m: 2 inds. nervously hopping back and forth on the church roof.

10/04/2003. Pumapampa, Rio Pachacoto, Santa Valley, Ancash, ca. 4200 m: Common in Puna grassland with Puya stand. 2 to 3 inds. climbing on trunk and withered inflorescence; ind. calling on top of it. Group display on stone walls and rocks. A large number of $C$. rupicola are attracted by an abandoned, roofless adobe house, covered with about 20 holes, two of them punctured. They approach the wall in small groups, visiting the niches, some inds. slipping through the punctured holes.

\section{Campephilus haematogaster}

05/03/1972. San Andrés de Cutervo, Cajamarca, 2400 m: 2 ind. on an isolated tree in pasture land at the edge of the humid montane forest. They generally move upward with vigorous thrusts, but may also move backward (Fig. 76).

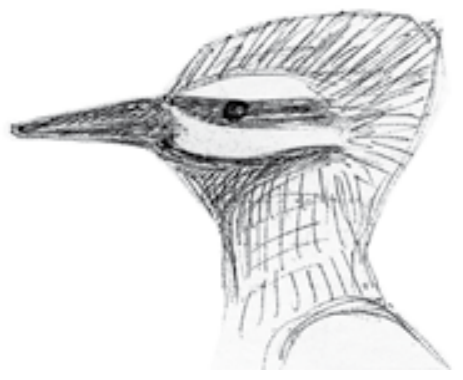

Figure 76. Campephilus haematogaster.

\section{Campephilus rubricollis}

01-03/07/1972. La Merced, Chanchamayo Valley, Junín, 800 m: Pair in abandoned plantation carving out a nest-hole in the trunk of an Avocado tree about $4 \mathrm{~m}$ above ground; observed on three consecutive days.

\section{PASSERIFORMES \\ FURNARIIDAE}

\section{Geositta peruviana}

19/10/1963. Lomas de Lachay, $70 \mathrm{~km}$ north of Lima, $400 \mathrm{~m}$ : Common in sand loma. Fresh burrow: The scratched out wet sand is dispersed evenly in the form of a fan (Fig. 77). In the neighbourhood several unfinished burrows.

11/09/1965. Same place: Display flight (see BP); only few fresh burrows.

24/08/1968. Same place: A digged up burrow $130 \mathrm{~cm}$ long and 55 $\mathrm{cm}$ deep. It is straight and shows no widening at the end; no nesting material; possibly unfinished.

13/02/1970. Laguna Orovilca near Huacachina, Ica: Numerous in small isolated oasis surrounded by dunes; in light Prosopis wood, but not in the adjacent desert.

11-21/02/1999. Samaca, Ica Valley, Ica, $200 \mathrm{~m}$ : Common in sand desert adjacent to the riperian vegetation. Ind. performing display flight. 


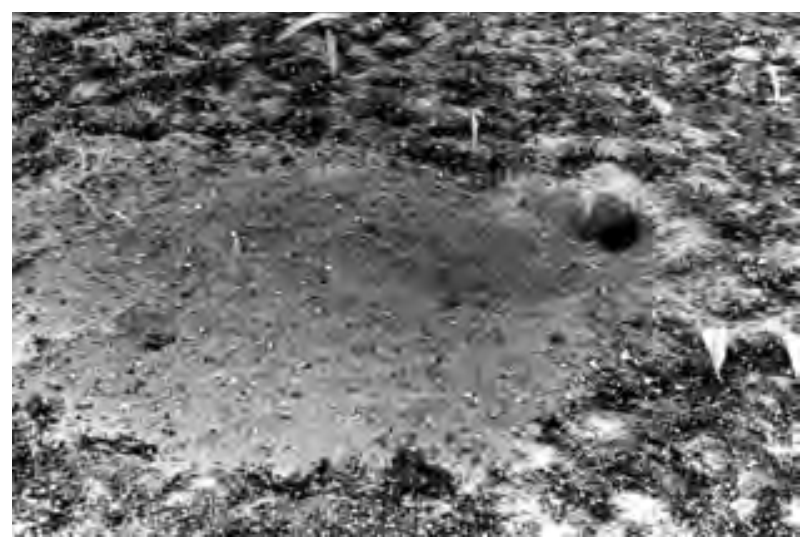

Figure 77. Burrow of Geositta peruviana.

\section{Geositta tenuirostris}

29/09/1970. Laguna Parinacochas near Incahuasi, Ayacucho, 3300 $\mathrm{m}$ : Fairly common on extended short-grass fields.

18/09/1971. Casta, Santa Eulalia Valley, Lima, 3400 m: 3 inds. on a bare plain with scattered trees.

\section{Geositta maritima}

\section{Sightings}

Lima: Canta, Rímac and Lurin Valleys between 600 and $1800 \mathrm{~m}$ in dry quebradas with scarce vegetation.

25/03/1967. Lurin Valley, Lima, 1100-1300 m: Numerous in dry quebrada with herbal vegetation (end of the rainy season). Solitary or in small groupes. Song - a short guttural rattle - is heard everywhere as well as a monosyllabic call. - Ind. carrying food.

11/08/1967. Lurin Valley, Lima, 1200-1700 m: In dry montane scrub with columnar cacti. Large number gathering at temporary creek to drink.

\section{Geositta crassirostris}

\section{Sightings}

Lima: Lomas de Lachay, Lomas de Pacta and Santa Eulalia Valley, $2700 \mathrm{~m}$

24/08/1969. Lomas de Lachay, $70 \mathrm{~km}$ north of Lima: Nesting place in a crevice of a big rock. Both ads. participate in the feeding. They approache the site cautiously, before disappearing into the narrow crevice.

\section{Upucerthia jelskii}

Sightings.- Andes of CP and SP between 3300 m (Santa Eulalia Valley, Lima) and $4200 \mathrm{~m}$ (Cañete Valley, Lima).

29/04/1967. Chumcha, Sta. Eulalia Valley, Lima, 3800 m: Ad. carrying food disappears in a crevice of a stone wall in montane scrub.

\section{Upucerthia serrana}

\section{Sightings}

NP: Cajamarca and La Libertad between 2800 and $3500 \mathrm{~m}$.

CP: Ancash and Lima between 3300 and $4200 \mathrm{~m}$.

Behavior.- Forages on the ground, running or hopping. It perches on lower branches in Polylepis wood. When startled, U. serrana emits shrieking calls.

25-27/03/1966. Chumcha, Sta. Eulalia Valley, Lima, 3400 m: Ind. disappears in a burrow on a scrub covered slope.

04/12/1966. Chumcha, 3900-4200 m: Fairly common in extended Polylepis forest. Ind. carrying food.

19/11/1972. Baños, Chancay Valley, Lima, 3800 m: Ind. with a batch of sheep wool. Warns loudly, hopping around nervously. Then flies to the opposite side of the valley.

\section{Cinclodes fuscus}

Vertical distribution.- BP states $2750 \mathrm{~m}$ as min. alt.; my lowest records: Lurin Valley, Lima 1400 and $2000 \mathrm{~m}$

28/11/1964. Huaura Valley, Lima, 4200 m: Nest with young hidden between two rocks at the shore of a small lake. The narrow entrance is at ground level. Both ads. participate in the feeding. They gather their food at the silty shore.

24/07/1966. Lurin Valley, Lima, 1400 m: Ind. gathering food on river edge in wet sand and between stones, also wading in shallow water, occ. dipping its head into the water. In one occasion it comes up with a big, black larva. It drops the prey and picks it up again several times in a row until finding the right position to swallow it. Then it stands for a long time motionless before resuming the search.

03/12/1966. Chumcha, Santa Eulalia Valley, Lima, 3300 m: Several food-carrying inds. A well developed young begging and flapping its wings gets fed twice. Song activity begins at 5 am: a repeated tsee'tsee'tsee'trr... Singing ind. rises its wings during song slowly until reaching a vertical position.

\section{Cinclodes taczanowskii}

Behavior.- Often in pairs; always close to the sea-shore, gathering food on washed over rocks without fear of heavy breakers; also on sandy beaches. Conspicuous courting behavior: Singing and flapping its wings simultaneously (occ. in duet), while posing on top of a rock.

Voice.- Voice.- a) excited trill in presence of partner, b) prolonged whinny-like song during flight, c) a sharp tsec.

27/11/1963. Chilca, $60 \mathrm{~km}$ south of Lima: Ind. attacks twice a group of Arenaria interpres, eventually chasing them away.

01/01/1964. Northern end of Playa Conchán, south of Lima: Pair in an irrigation channel, one foraging, the other bathing in the shallow, clear water (provided by a nearby ground water well). It stands breast-deep in the water, dipping its head again and again into it, at the same time flapping vigorously its wings. After the bath, it perches on a stone and proceeds carefully to tidy up its plumage: The wing feathers spread and turned to an upright position, it several times 'combes' them with its bill, putting each feather in its place. The partner, meanwhile, continues the search for food, wading Cinclus-like through the water. Both emit occ. a contact call.

08/08/1972. Playa Chira, south of Lima: Ind. hunting small, about $1 \mathrm{~cm}$ long Emerita.

05-08/02/1964. Playa León Dormido, 80 km south of Lima: Resident pair at the rocky end of the beach. They are searching for food not only on the rocks but also on the beach, feeding on live as well as dead Emerita. One ind. is busy pecking at a mussle whashed ashore. It rips off large pieces, chews on them or tries to cut them up. Another is holding an Emerita tight with one foot, while eating it gradually - . Whenever a third ind. appears, it is chased away by the pair.

\section{Furnarius leucopus}

Vertical distribution.- Max. alt: Contumazá, Cajamarca, 2700 m (BP "below $2100 \mathrm{~m}$ ")

11/01/1964. Near Batán Grande, Lambayeque: Pair in Prosopis wood: Both participate in building a nest on a horizontal branch of a tree about $4 \mathrm{~m}$ above ground. They are busy carrying construction material to the site. The nest consists of cow dung mixed with dry grass and small pieces of wood (remains beneath nesting site).

13/01/1966. Matapalo, Tumbes: Common in Bombax wood. F. leucopus frequents the numerous puddles, that have formed on the road after rainfall. There, they find the material needed for nest-building.

17/01/1966. Near Zaña, Lambayeque: Numerous nests on old Salix and Prosopis lining a rice field (5 on a single willow)

\section{Phleocryptes melanops}

26/10/1963. Totoral de Villa, south of Lima: Small patch (about $10 \times 10 \mathrm{~m}$ ) of totora young growth with 6 nests in different stages. The 
dark colour of one of them indicates, that it is under construction. The relatively low position of the nests ( at an average of $1 \mathrm{~m}$ ) is due to the height of the vegetation (about $1.5 \mathrm{~m}$ ). Two nests are only $30 \mathrm{~cm}$ apart from each other, another two about $40 \mathrm{~cm}$.

It seems, that the male starts building several nests at a time, whereas the female finally chooses one of them for breeding. Some of the nests are left unfinished or are not suitable for breeding. (Fig. 78-80).

Nest with clutch at the edge of totora patch, about $2,5 \mathrm{~m}$ high. The extremely robust, egg-shaped nest is suspended from five stems of Typha. Measures: $15 \mathrm{~cm}$ high, $10 \mathrm{~cm}$ wide: entrance $3 \mathrm{~cm}$. Contains three bluish-green, identical eggs, measuring $19 \times 24 \mathrm{~mm}$.

09/11/1963. Same place: Nests I-IV (Fig. 82) are situated at a height of $2-2,5 \mathrm{~m}$, nest $\mathrm{V}$ at $60 \mathrm{~cm}$. They are suspended from three or more stems of Typha; three nests with fledglings, two with eggs (two eggs each). Minimal distance between two occupied nests: $20 \mathrm{~m}$. In the neighberhood of each occupied nest, there are one or two unfinished ones. Exclusive building material seems to be Typha fibers, which in a wet, half-rotten state are excellently suitable for weaving. The studied nests vary in height between 12 and $18 \mathrm{~cm}$. The entrances are between 2,5-3 cm wide and $1,6-2 \mathrm{~cm}$ high.

27/11/1963. Lagunas de Chilca, $65 \mathrm{~km}$ south of Lima: Several nests in Scirpus covered, small ponds, $20-40 \mathrm{~cm}$ above water. At one place, three nests are only $1 \mathrm{~m}$ apart from each other, one of them is under construction. - Ad. is leaving its nest, which is suspended from several Scirpus stems, hanging in a slanted position close to the water surface.

18/11/1967. Totoral de Villa: Nest with clutch of three eggs near the edge of a small patch of totora situated about $3 \mathrm{~m}$ high (Fig. 81).

13/02/1970. Laguna Orovilca near Huacachina, Ica: Present in the totoral of this isolated, small oasis surrounded by dunes. The nearest cultivated land is about $5 \mathrm{~km}$ away.

15/01/1973. Puerto Viejo, $70 \mathrm{~km}$ south of Lima: Song activity in the small ponds with Typha and Scirpus. Fresh nest at initial stage.

18/07/1988. Near Chincheros, Cusco, $3600 \mathrm{~m}$ : Present in small, Scirpus covered lagoon. Ind. flutters from stem to stem close to the water surface, picking up small portions of algae and other floating vegetal fibers, presumably using it as building material.

12/03/2003. Lago Titicaca, Puno, $3800 \mathrm{~m}$ : Ind. snatches insects from the Limnaceae covered surface of the lake, hopping from stem to stem.

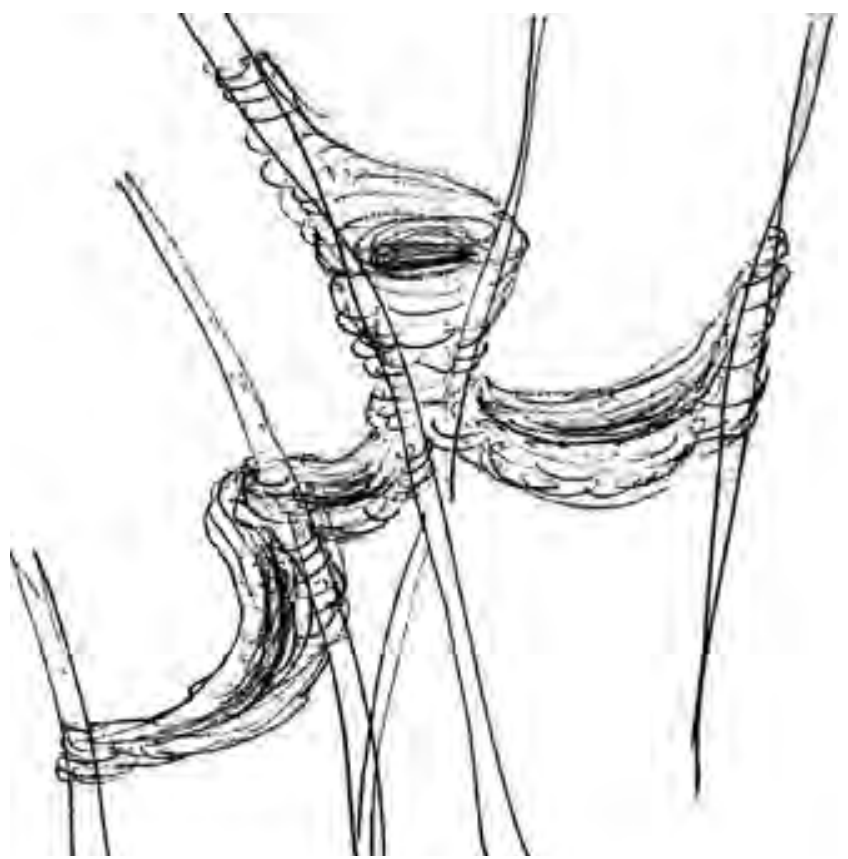

Figure 78. Phleocryptes melanops: defective product of its nestbuilding fervor.
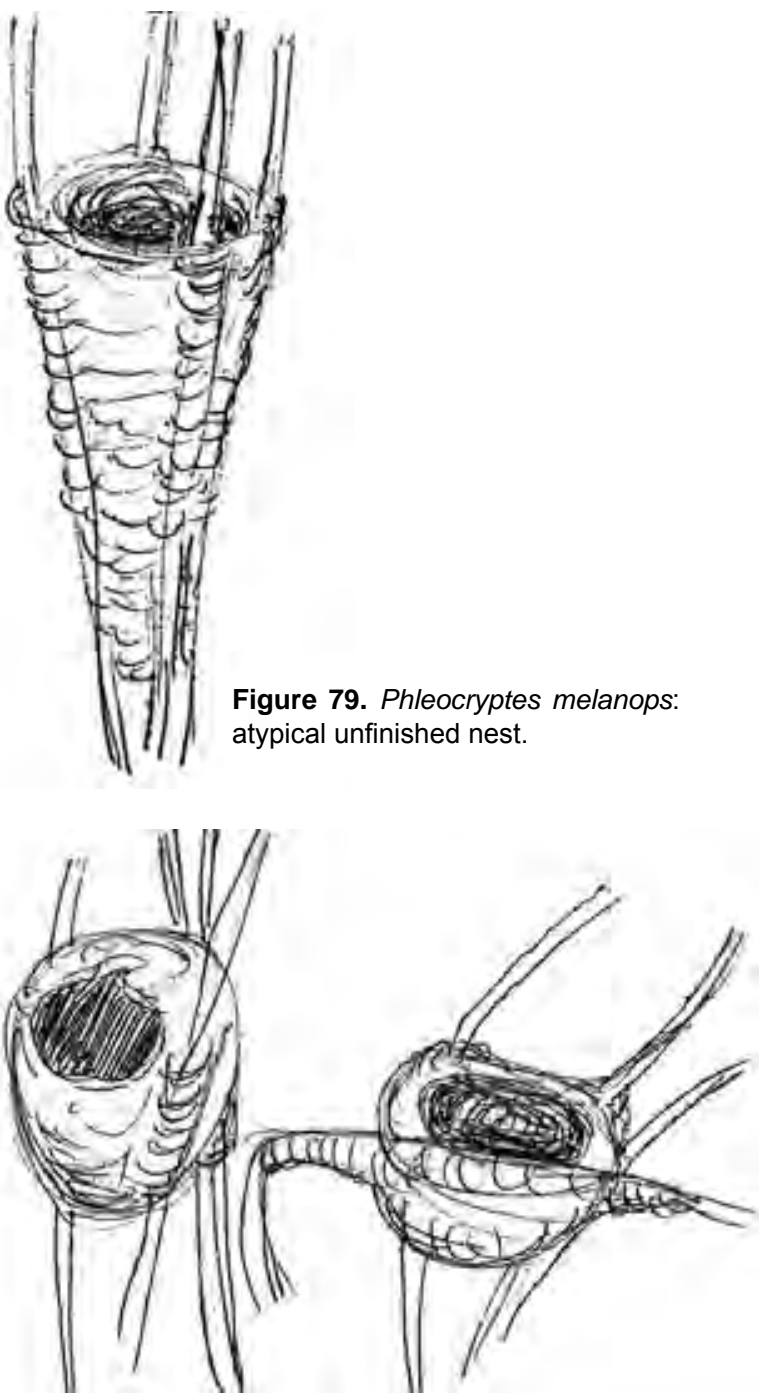

Figure 80. Phleocryptes melanops: unfinished and abandoned nests.

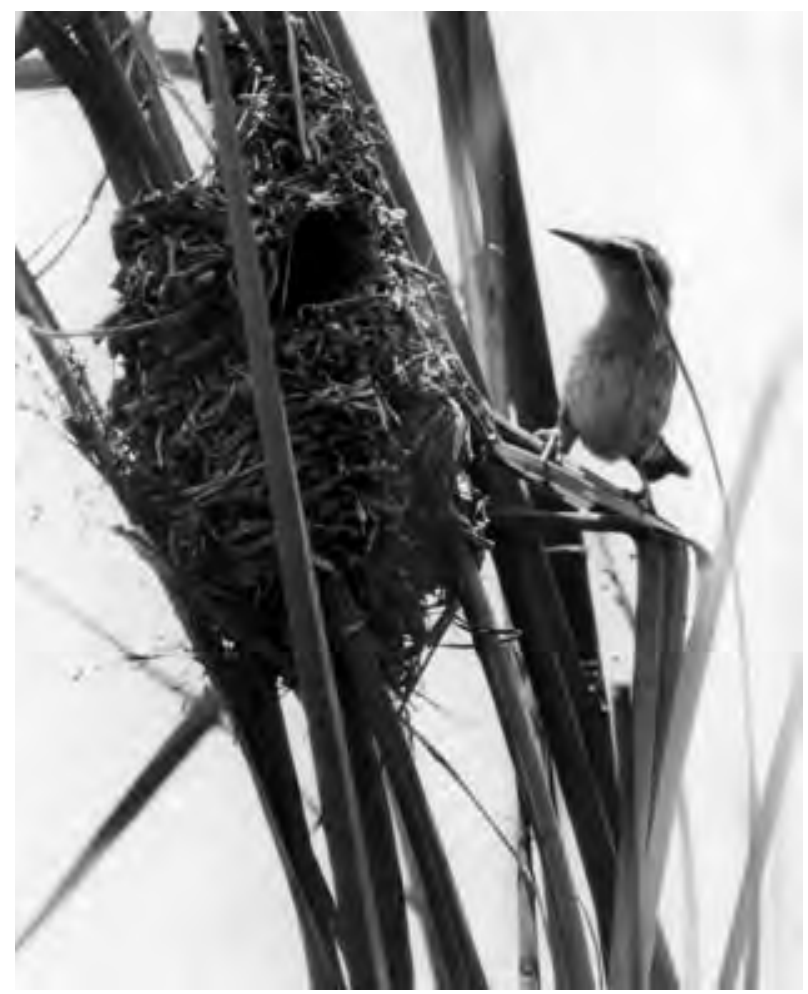

Figure 81. Phleocryptes melanops: at nest. 


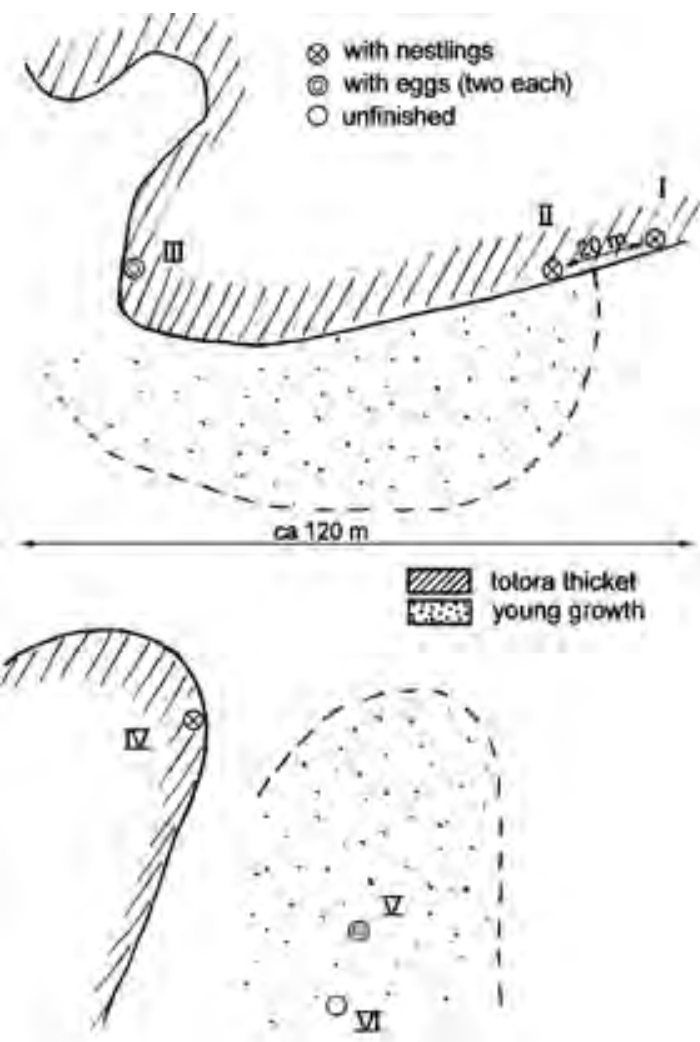

Figure 82. Breeding area of Phleopcryptes melanops.

\section{Cranioleuca antisensis}

Sightings/Habitat.- West slope of CP: Lima: Chumcha, Santa Eulalia Valley, 4200 m; Zárate, Rímac Valley, 3000 m; in Polylepis wood and humid montane forest.

Behavior.- Combines the habits and skills of woodpeckers and titspintails. Forages in branch thickets and trees overgrown with moss or lichen. Climbs upwards on stems and downwards headfirst on slanting branches. May also hang upside down in 'beards' of lichen or moss. When serching for hidden insects, it stabs its bill forcefully into cushions of moss or inspects crevices in the bark.

11-12/06/1966. Zárate, Rímac Valley, Lima 3000 m: Common in humid montane forest. Pair engaged in courting ceremony in the interior of a tree. Male is perched on a horizontal branch. The more excited his song (see BP) gets, the more he opens his wings until they reach a vertical position, rising at the same time single feathers of the crest. Without interrupting the song, he hops around nervously. Meanwhile the female goes about foraging without paying attention, emitting a short call now and then. Only once she can not resist the courting effort of the male: She sits down close to him, and for a short moment their bills meet.

\section{Asthenes pudibunda}

Zárate, Rímac Valley, Lima, 3000 m:

$15 / 09 / 1963$. Ind. hunting insects climbing about in a shrub on a large boulder, which rises above the forest.

$13 / 06 / 1965$. Several inds. in scrub thicket at the edge of the forest.

11-12/06/1966. Several records in light forest and at forest edge; also on the ground in company with finches. Pair feeding on a lichencovered scrub, calling $(\rightarrow 26 / 04 / 1969)$

Sheque-Chumcha, Sta. Eulalia Valley, Lima:

$01 / 11 / 1965-03 / 12 / 1966$. Several sightings in montane scrub, $3600-3800 \mathrm{~m}$

26/04/1969. Several sightings in Polylepis wood, 4100 m. Call: a distinctive, incessant kew'whic, keew'whic.

\section{Asthenes cactorum}

Regularly sighted above Urbanización California, Chosica, Rímac Valley, Lima, 800-900 m in dry quebrada with columnar cacti:

24/09/1964. Ind. hunting insects in crevices of rocks, beneath stones, in dry scrub and on columnar cacti.

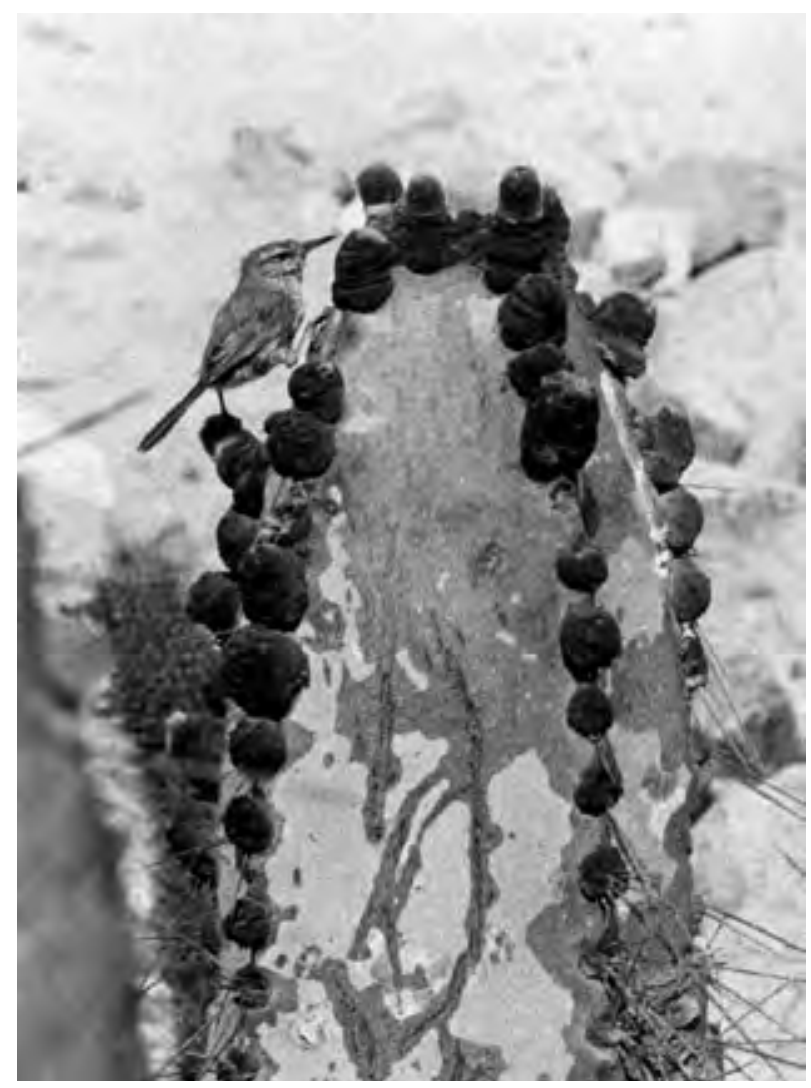

Figure 83. Asthenes cactorum.

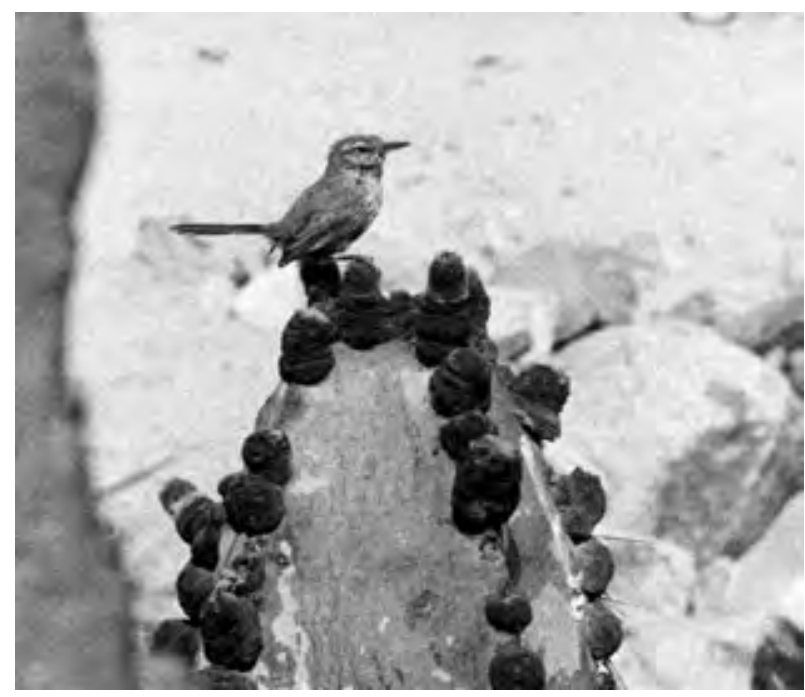

Figure 84. Asthenes cactorum.

11/04/1965. Song activity: soft trill. Call during flight: tsip or tsiAp.

29/08/1965. Courting activity: Intense, prolonged trill. Two or three inds. chasing each other. Two males singing for a short time vehemently on the same cactus, with their tails cocked.

11/04/1971. Pair collecting ants on columnar cactus (Fig. 83/84). The ants gather in great numbers on cacti, attracted by the juice that oozes from the blossoms and branches.

$31 / 07 / 1983$ and $04 / 08 / 1983$ Nine nests recorded in a small que- 


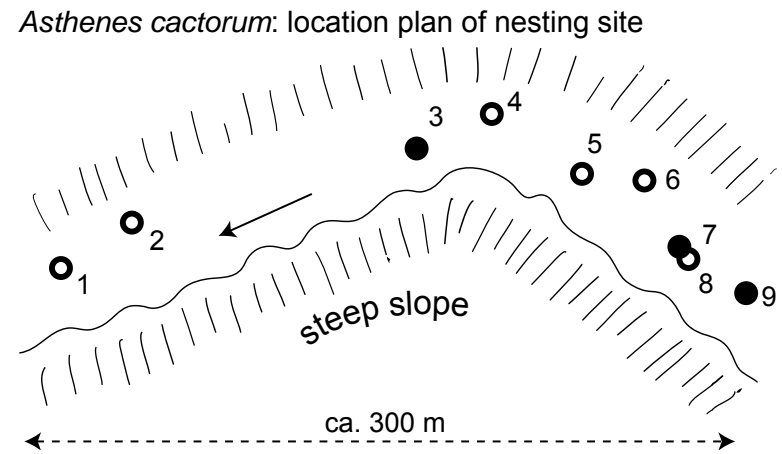

Figure 85. Empty circle: nest decaying or unfinished; filled circle: nest in good condition.

brada in different state of conservation; no breeding activity (Fig. 85). All are situated on columnar cacti at an average height of $1.5 \mathrm{~m}$. Six of them are placed between two columns (e.g. No. 3), two at ramification (e.g. No. 9). The nests are true fortresses. The outside is protected with spines (not single spines, but a kind of 'pin-cushion', found in great numbers at the foot of the cacti). The construction material consists of twigs and branches 5 to $10 \mathrm{~cm}$ long $(\max .20 \mathrm{~cm})$. The interior is padded with brown cactus 'wool'. The nest as a wohle is nearly indestructible - an amazing achievement for such a fragil bird!

\section{Description of two nests:}

N3 (Fig. 87): Height of cactus $1,7 \mathrm{~m}$. Entrance tube: slightly ascending, length $14 \mathrm{~cm}$, diam. in front $6-7 \mathrm{~cm}$, at rear $4-5 \mathrm{~cm}$. The nest is about $50 \mathrm{~cm}$ high, $15-17 \mathrm{~cm}$ wide in front and $25 \mathrm{~cm}$ on the side.

N9 (Fig. 86/88): The tube-like entrance is $1,1 \mathrm{~m}$ above ground; its diam. measures $4,5 \mathrm{~cm}$. Height of the nest about $40 \mathrm{~cm}$, width in front $22 \mathrm{~cm}$ (Fig. 86).

\section{Sightings in other areas:}

01/10/1967. Hacienda Trapiche, Canta Valley, Lima, 900 m: Ind. in semi-desert with columnar cacti and scattered scrub.
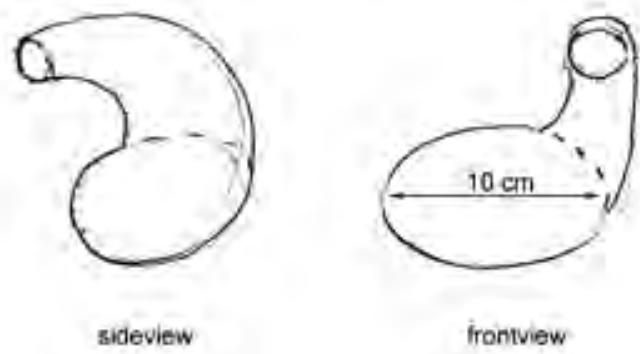

Figure 86. Asthenes cactorum, interior of nest 9

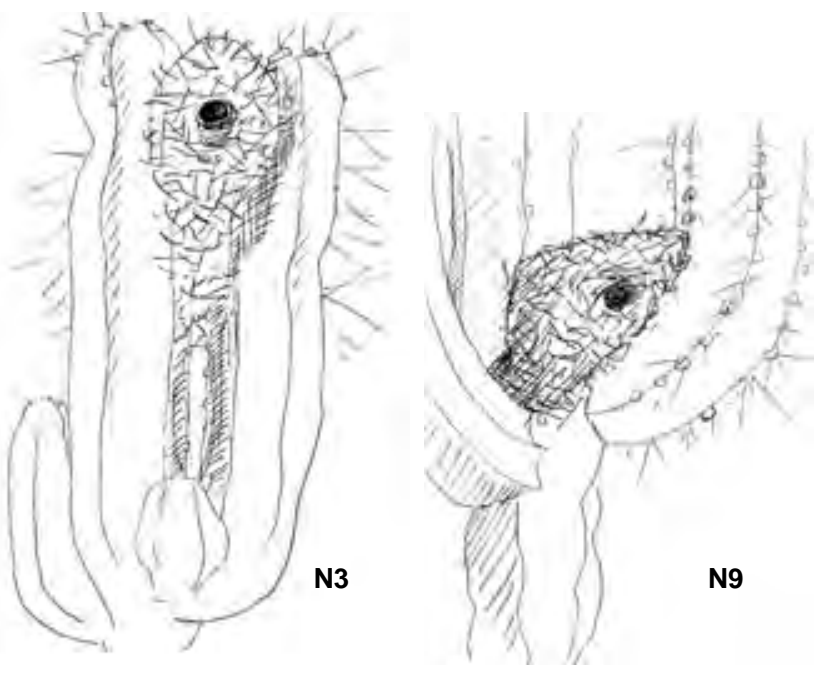

Figure 87- 88. Asthenes cactorum, nest 3 y 9.
01/10/1970. Between Sóndor and Cháparra northwest of Chala, Arequipa, 2000-2200 m: Several sightings; nests on columnar cacti.

\section{Asthenes humilis}

06/07/1993. Between Chugay and Aricapampa, La Libertad, 3500 $\mathrm{m}$ : Ind. hunting insects in Paramo grassland, often performing short leaps in order to glean prey from stones or low vegetation.

\section{Asthenes dorbignyi}

29/09/1970. Slopes of Nevado Sarasara, Ayacucho, 3700 m: Fairly common in sparse but extended Polylepis wood. Foraging in the trees, only once on the ground. Often raising tail. Song begins with a dry tree'tree'tree followed by a descending twee'twee'twee'twee. Call: a fine trill at the same pitch.

03/03/2003. Between Arequipa and Las Salinas, Arequipa, ca. 3500 $\mathrm{m}$ : Montane scrub with Polylepis. Bulky nests on scrub; no birds sighted. Nests on two scrubs about $50 \mathrm{~m}$ apart, one with one, the other with three nests (two on top of each other).

\section{DENDROCOLAPTIDAE}

\section{Sittasomus griseicapillus}

16/02/1964. Sauce Grande, Amotape Mountains, 700-800m: Several sightings in deciduous forest.

\section{Lepidocolaptes souleyetii}

\section{Sightings/Habitat}

NP: Tumbes, Piura and Lambayeque in semi-humid Bombax forest and dry Prosopis forest up to $600 \mathrm{~m}$.

Behavior.- Examines crevices in the bark of Prosopis by holding its head in a slanted position. Thanks to its long and slender bill, it is able to extract prey, that is inaccessible for other birds.

15/02/1964. Hacienda Mallares near Sullana, Piura, 400m: Begging young on a Prosopis.

\section{THAMNOPHILIDAE}

\section{Sakesphorus bernardi}

\section{Sightings/Habitat}

NP: Tumbes, Piura, Lambayeque, La Libertad; in deciduous forest, semi-humid and dry forest and scrub. Highest record: Hacienda Chuquizongo, Cicama Valley, La Libertad, 1700 m (BP: "below 1200 m on west slope").

Behavior.- Perches quietly on branches, often rising crest, occ. bobbing tail downwards. Very conspicuous vocal emissions (> BP).

12/01/1966. Near Puerto Pizarro, Tumbes: Pair in semi humid vegetation with trees, scrub and cacti, hunting insects; twice feeding each other. On one occ. female feeds male, on the other it is not clear, who is feeding whom.

\section{Myrmotherula axillaris}

18/01/1970. Panguana Research Station, Rio Llullapichis, Huánuco, $300 \mathrm{~m}$ : Male netted at edge of primary forest.

\section{Cercomacra cinerescens}

17/01/1970. Panguana Research Station, Rio Lullapichis, Huánuco, $300 \mathrm{~m}$ : Pair netted in humid forest, $1 \mathrm{~m}$ above ground (BP: "in midstory and canopy; forages higher than other Cercomacra").

\section{GRALLARIIDAE}

\section{Grallaria andicolus}

\section{Sightings}

NP: Hacienda Moyán, Rio Chusgón, La Libertad, 3600 m.

CP: Lima: Huaura and Santa Eulalia Valleys (Chumcha) between 3300 an $4300 \mathrm{~m}$. 
Habitat/Behavior.- Mostly on grass covered ground, open montane scrub and sparse Polylepis wood. Shy; when aroused, takes cover immediatly in thicket or on a tree.

Voice.- Because of its characteristic voice and its secretive behavior, $G$. andicolus is more often heard than seen. Its melancholic trill psEEErr ascends slightly at the beginning and descends abruptly at the end. Song activity begins early (Chumcha at 5.50 on a cold and foggy morning), is most intense in the morning but lasts all day long.

\section{MelanopareiIDAE}

\section{Melanopareia elegans}

16/02/1964. Sauce Grande, Amotape Mountains, Piura, 800 m: Pair in deciduous forest (colected by W. Markl).

30/07/1965. Hacienda Chuquizongo, Chicama Valley, La Libertad, $1700 \mathrm{~m}$ : Ind. in scattered thorn scrub on the ground.

Jan. 1967. Olmos-Abra Porculla, Lambayeque, 700 m: Ind. in deciduous forest on the ground.

\section{TYRANNIDAE}

\section{Myiopagis subplacens}

15-16/02/1964. Sauce Grande, Amotape Mountains, Piura, 700 $\mathrm{m}$ : Several sightings in deciduous forest.

\section{Elaenia albiceps}

BP states, that modesta winters on east slope, which is not consistent with the following sightings:

24/07/1966. Lurin Valley, Lima, $1400 \mathrm{~m}$.

10/06/1976 and 26/07/1988. Rímac Valley, Lima, $800 \mathrm{~m}$.

Behavior.- Catches insects in flight or within canopy of trees. Unlike other Tyrannidae it does not perch on exposed places, like treetops but takes cover at the periphery or lower branches of trees from where to start its sallies.

\section{Camptostoma obsoletum}

\section{Sightings}

NP: Piura 100-700 m, Cajamarca 1600 m, La Libertad sealevel and Marañón Valley 1300/2400 m

CP: Common on coast and in coastal valleys between sealevel and $1000 \mathrm{~m}$. Highest records: Rímac Valley $2600 \mathrm{~m}$, Huaura Valley $2600 \mathrm{~m}$.

Southernmost sighting: Rio Ingenio near Palta, Ica.

\section{Voice}

a) (tew)' TEW' tew'tew'tew'tew: descending, accelerating and getting weeker.

b) wee'WEEW!: resembles the admiring whistle of a boy for a girl.

c) strong, prolonged trill.

d) weee... : soft, somewhat melancholic; serves probably as contact call.

Behavior.- Climbs and hops skillfully through interior of bushes and trees collecting insects and larvae. Snatches its prey from beneath the leaves by making short leaps or in fluttering flight. Often rises and lowers its crest in short intervals during feeding or singing. - On one occ. I observed an ind. on a rose bush, feeding extensively on aphids.

15-16/02/1964. Sauce Grande, Amotape Mountains, Piura, 600$700 \mathrm{~m}$ : Common in deciduous forest.

11/04/1964. Rio Chillón near mouth, Lima: Nest with young on Tessaria at river edge about $3 \mathrm{~m}$ above water: hemispherical bowl mostly made of grass stems. It hangs precariously within the twigs. Both ads. are feeding.

28/11/1965. Urbanización California, Chosica, Rímac Valley, Lima, $800 \mathrm{~m}$ : Numerous in scrub along irrigation channel. Different vocal emissions (a,b,c); 2 inds. occ. trilling together excitedly.

\section{Serpohaga cinerea}

\section{Sightings}

NP: Cajamarca (Cutervo) $2000 \mathrm{~m}$

CP: west slope: Lima sea level up to $2700 \mathrm{~m}$ (Huaura Valley). BP indicates $800 \mathrm{~m}$ as min. alt. Sightings below $800 \mathrm{~m}$ : Mouth of Rio Chillón, Canta Valley; Cañete Valley $\mathbf{4 0 0}$ m; Chancay Valley 500 m; east slope: Pasco 2600 m, Junín 700/1000 m; Marañón Valley: Ancash, Baños de Chavín 3300 m (max. alt. acording to BP 3100 m).

SP: Cusco 2600/3000 m.

Sept. 1966. Rio Chancay, Lima, 500 m: Up to five inds. gather on a $50 \mathrm{~m}$-section of the shallow, pebble-strewn stream. They perch on stones in the stream, catching insects in the air or on algae covered stones, holding for moments on to the wet and slippery surface. They also snatch insects form surface of the water. Warble-like song: tirr'tirr'tseer.

17-19/09/1968. Rio Paucartambo, Pasco, 2600 m: Solitary or in pairs. Perching in shade of riverbank vegetation or on rocks. $S$. cinerea finds plenty of prey over the fast flowing, torrential river. Occ. it snatches the mosquitoes right out of the spray. Call: A repeated tswee'tswee 'tswee..

19/03/2003. Ollantaytambo, Cusco, ca. $2600 \mathrm{~m}$ : Ind. at the edge of an inca irrigation channel, later in the nearby terraces. In search for food it hops along the rim of the stonewalls, often cocking its tail.

\section{Euscarthmus meloryphus}

Voice.- Reveals its presence by its distinctive and repeated call, that consists of two to four notes, with the emphasis always on the second one.

25/07- 02/08/1965. Coina, Chicama Valley, La Libertad, 1500 m: Fairly common in hedges and montane scrub.

Jan. 1966 and Jan. 1967. Between Olmos and Abra Porculla, Lambayeque, 600-700 m: Fairly common in deciduous forest; also near Tumbes.

02-03/08/1966. Aricapampa, Marańón Valley, La Libertad, 2400 $\mathrm{m}$ : Several sightings in quebrada with dense vegetation.

\section{Mionectes oleagineus}

18/01/1970. Research Station Panguana, Rio Llullapichis, Huánuco, $300 \mathrm{~m}$ : Ind. netted in primary forest; length $11,5 \mathrm{~cm}$, wings $6,5 \mathrm{~cm}$.

\section{Tachuris rubrigastra}

\section{Sightings}

Coast: Lima: Regularly in Villa; also in Pachacámac, Conchán and

Puerto Viejo (70 km south of Lima); La Libertad: Mouth of Rio Jequetepeque

Andes: Cusco: Laguna near Chincheros, 3600 m; Laguna Lucre, $3100 \mathrm{~m}$

Habitat/Behavior.- Totorales; vivacious and curious; moves easily through marsh thickets; climbs skillfully on stems of Typha and Scirpus, gleaning insects from leaves and stems.

09/11/1963. Villa, south of Lima: Two ads. feed two nearly grownup fledglings. While the ads. are gathering food in the adjacent marshland, the young perch quietly at the edge of the totoral. On one occ., when a fledgling tries to follow the ad., it is immediatly driven back to cover.

15/07/1993. Huanchaco, La Libertad: Fairly common in the artificial, rectangular ponds, covered with Typha. Courtship display: Male hangs upside down on a Scirpus stem, spreading its white-marked tail. - Two ads. are busy building a nest; occ. both are at work simultaneously, stuffing Typha fibers (up to $10 \mathrm{~cm}$ long) into the rim of the nest. Occ. one of the ads. cuddles into the nest and - so it seems - moves its feet rapidly up and down (probably to strengthen the nest and to adapt it to its body). - Ad. breeding: The nest is about $1 \mathrm{~m}$ above the water, fixed onto two stems of Typha (Fig. 89). 
23/04/2005. Same place: Two young are begging incessantly. They move around hopping and fluttering; vocal emissions of a third invisible young.

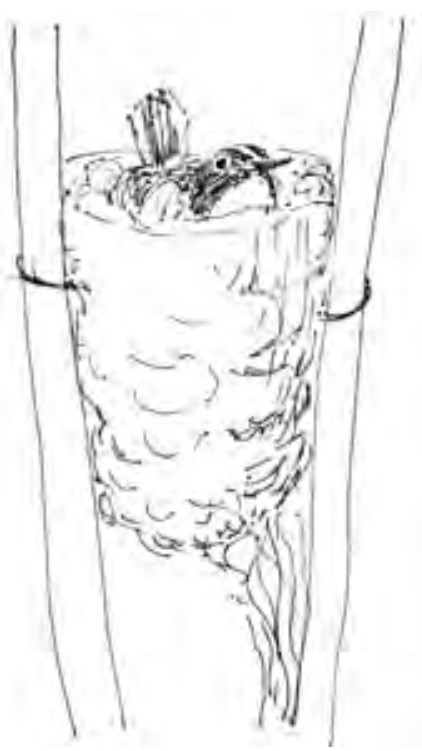

Figure 89. Tachuris rubrigastra breeding.

\section{Todirostrum cinereum}

15/02/1964. Sauce Grande, Amotape Mountains, Piura, 650 m: Ind. in deciduous forest.

Jan. 1967. Puente 28 de Julio, Rio Marañón, Cajamarca/Amazonas, $500 \mathrm{~m}$ : Ind. hunting in riparian vegetation.

05/02/1999. Moyobamba, San Martín, $850 \mathrm{~m}$ : Second growth with dispersed trees. Ind. gleans insects from foliage, occ. jumping or fluttering. Song: dew'dew'Di'dew in rapid succession.

\section{Todirostrum chrysocrotaphum}

31/07/1964. Juanjui, Rio Huallaga, San Martín, 300 m: Forest and second growth; Ind. hunting in interior of a tree, hopping from branch to branch, occ. leaping to catch insects in the air.

\section{Myiophobus fasciatus}

Records limited to Lima: On coast and in coastal valleys (Canta, Lurin, Mala) up to $1600 \mathrm{~m}$.

Prefers thickets and dense scrub near streams, rarely venturing into the open.

Perches low $(1 / 2-2 \mathrm{~m})$, often changing site.

05/05/1963. Canta/Arahuay Valley, Lima, 1600 m: Ind. netted in riparian vegetation (Fig. 90/91).

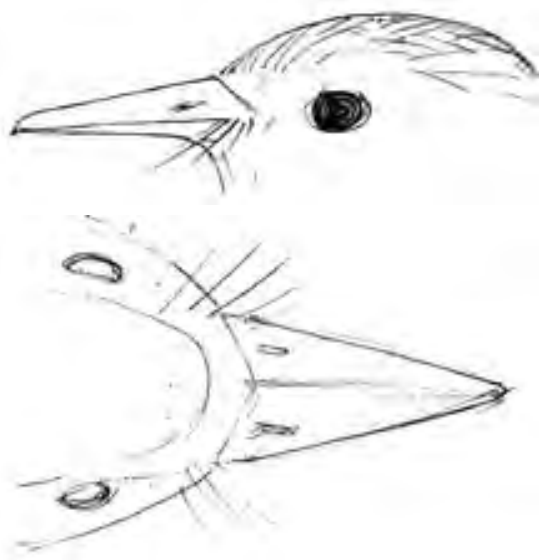

Figure 90-91. Myophobus fasciatus

\section{Pyrrhomyias cinnamomea}

02/03/1972. San Andrés de Cutervo, Cajamarca, 2400 m: Ind. perched on a liana at the edge of the humid montane forest. It catches insects in the air, constantly surveying the surroundings by moving its head to and fro or holding it at different angles.

\section{Contopus cinereus}

\section{Sightings}

NP: Piura 700 m, La Libertad 1500/2400/2800 m.

CP: Lima: 1600-3400 m (max. alt. acording to BP $2800 \mathrm{~m}$ )

Behavior.- Usually perching on an exposed bare branch, catching insects exclusively in the air. Emits a two, occ. three syllable call often after returning to perch. It serves probably to mark its territory. Characteristic snapping sound of bill when catching a prey or as a warning.

16/02/1964. Sauce Grande, Amotape Mountains, Piura, 700 m: Ind. in deciduous forest.

02/02/1964. Between Canta and Viuda-Pass, Lima, 3400 m: Ind netted in semi-humid montane scrub. Length: $13 \mathrm{~cm}$; three outer tail feathers $16 \mathrm{~mm}$ shorter then the rest (molt).

25/07- 02/08/1965. Coina, Chicama Valley, La Libertad, 1500 $\mathrm{m}$ : Most common tyrant in montane scrub with patches of pastures and fields.

02-03/08/1966. Aricapampa, Marañón Valley, La Libertad, 2400 $\mathrm{m}$ : Several sightings in narrow quebrada with scrub and trees.

27/07/1968. Santa Eulalia Valley, Lima, 1600 m: Ind. in close neighbourhood to Ochthoeca leucophrys, temporarily perching only 5 $\mathrm{m}$ apart. They do not take notice of each other.

22/03/1970. Between San Bartolomé and Zárate, Rimac Valley, Lima, 2100 m: Semi-humid montane scrub. Nest built on horizontal
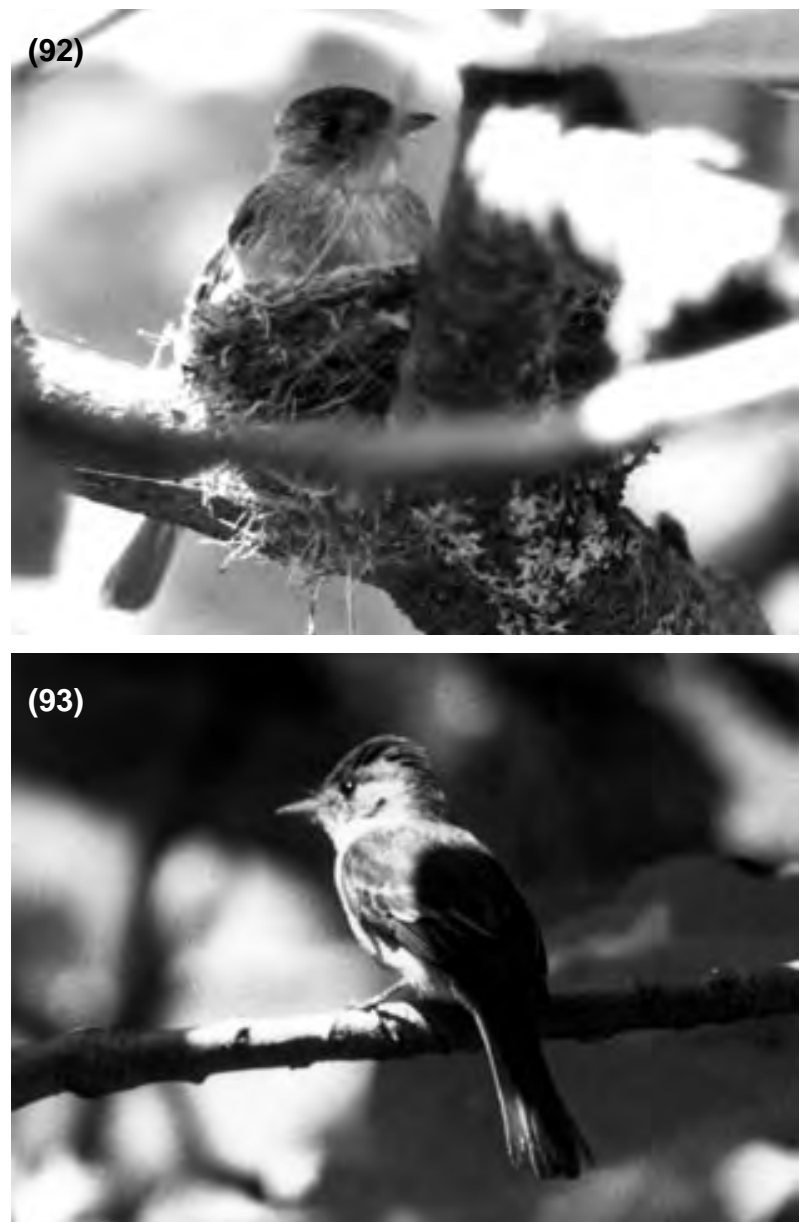

Figure 92-93. Contopus cinereus at nest, perched near nest. 
fork of a branch of Carica, 2,50 m above ground, neatly built with grass stems and other vegetal fibers; one stem protruding $12 \mathrm{~cm}$ tangentially. Outer diam. $8 \mathrm{~cm}$, inner diam. $4,5 \mathrm{~cm}$, height $4 \mathrm{~cm}$, depth $2,5 \mathrm{~cm}$. Two cream coloured eggs with dark and light purple-brown splatters, accumulated around the equator. Sample egg: $13 \times 17,5 \mathrm{~mm}$. Male and female are present. When we approache the tree, one of the ad. 'attacks' us, emitting three or four times a snapping sound. During our presence, both ads. call often from nearby scrub and tree (Fig. 92-95).
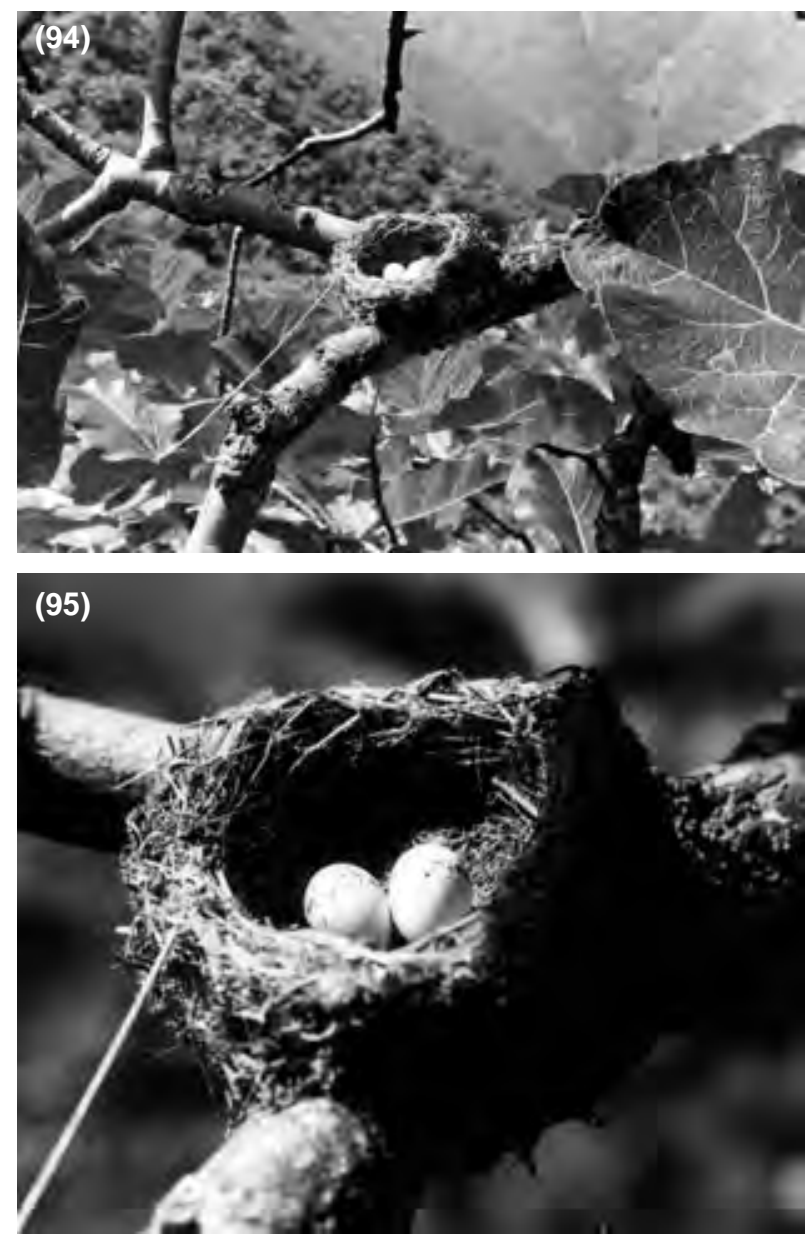

Figure 94-95. Contopus cinereus nest with clutch.

11/07/1993. Pataz, Marańón Valley, La Libertad, 2800 m: Ind. perching on a creeper on rock surface. Returns after sallies to the same place during at least $15 \mathrm{~min}$.

\section{Sayornis nigricans}

\section{Sightings}

West slope: La Libertad $1500 \mathrm{~m}$.

East slope: Cajamarca 2000 m, Ucayali 500 m, Huánuco 2100 m, Pasco 2600 m, Junín 800 m, Ayacucho 1200/1500 m, Apurímac (Pampas Canyon) $1300 \mathrm{~m}$.

Behavior.- Water-bound; prefers fast flowing streams. Perches on rocks or pebbles in midstream or at river bank, also on bushes or trees. Catches insects in the air by short sallies or leaps. May eventually pursue a prey over a short distance, performing acrobatic turns.

\section{Pyrocephalus rubinus}

\section{Sightings}

Maximum altidude:

NP West slope: Chicama Valley, La Libertad, 1500 m. East slope: Cajamarca, $2700 \mathrm{~m}$.

CP West slope: Lurin Valley, Lima, $1400 \mathrm{~m}$.

SP West slope: Moquegua, $1600 \mathrm{~m}$.
Feeding.- Pyrocephalus rubinus feeds exclusively on insects and similar small prey. Trees, scrub, reed, telephone wires, rocks or a clod of earth serve as hunting perches. It often changes place within its territory. Certain inds. stick to the same place for days, weeks or even months. During four weeks an ind. was perching on a soccer goal post. One ind. perched on the same tree - often on the same branch - in a long row of Casuarinas during three months. P. rubinus catches its prey on the ground, occ. in the air. When hunting in the air, it occ. pursues its prey for a short distance in a zigzag flight. When snatching an insect from the ground, it immediately returns to a perch to swallow it.

The diagram refers to the urban area of Lima, especially La Victoria and Miraflores. It shows, that two main periods of reproduction can be distinguished: March to June and Sep to Nov. The two periods may overlap: When some couples are still feeding their young, others are starting the next breeding cicle.

\section{Reproductive periods of Pyrocephalus rubinus}

\begin{tabular}{|c|c|c|c|c|c|c|c|c|c|c|c|c|}
\hline & 1 & 2 & 3 & 4 & 5 & 6 & 7 & 8 & 9 & 10 & 11 & 12 \\
\hline$c$ & & & $\ldots$ & & & & & -- & - , & $\because \ldots$ & & \\
\hline $\mathrm{n}$ & & & $\mid$ & & & & & & & & & \\
\hline b & & & & & & & & & & $\ldots$ & & \\
\hline fn & & & & & & & & & 1 & & 1 & \\
\hline fo & 1 & | & & & & | & & | & & & & \\
\hline
\end{tabular}

Figure 96. 1-12: month/year; c: courting (song and display flight); $\mathrm{n}$ : nest-building; b: breeding; fn: feeding at nest; fo: feeding outside nest; | single record; --- observation period

Courting.- Display flight and song: Male performs its display flight usually from tree tops or outer branches of a tree. The flight may vary: either starting with a steep curve, levelling off at the top, or discribing a broad, spiral-like curve. The ascense is accompanied by an uninterrupted song ts'PREW-ts'PREW-ts'PREW... At the culmination it turns back silently to the starting point, opening wings and lifting tail several times. - Song (without display flight) can be heard all year round and at any time of the day. Song activity begins before dawn and ends after dusk. In the city it is stimulated and therefore prolonged by artificial illumination. During courtship the male emits a sharp plip or a snapping noise with his bill, e.g. in presence of a female. When excited, he raises its crest.

Nest locations.- I have found nests exclusively on trees. P. rubinus prefers horizontal branches near the periphery. The nests are generally placed in the fork of a branch. Considering five nesting sites, the height above ground varies between 2,5 and $6 \mathrm{~m}$.

08/10/1963. Miraflores/Lima: Nest with clutch in a row of Casuarinas at the edge of a sportsfield, about $3 \mathrm{~m}$ high, located precariously at the outer part of a branch. It consists mainly of Casuarina 'needles', as well as small twigs, cotton, some grass stems and wool threads. The inside is lined with downy chicken feathers, the outside is camouflaged with spider's web. Measures: Inner diam. 4,5-5 cm, outer diam. 8,5-11 $\mathrm{cm}$, height $3,5 \mathrm{~cm}$, depth $2,5 \mathrm{~cm}$. The two eggs are dull-white with a broad band of brown, grey and blackish splatters. Both eggs measure $14 \times 18 \mathrm{~mm}$. Nest later abandoned (Fig. 97).

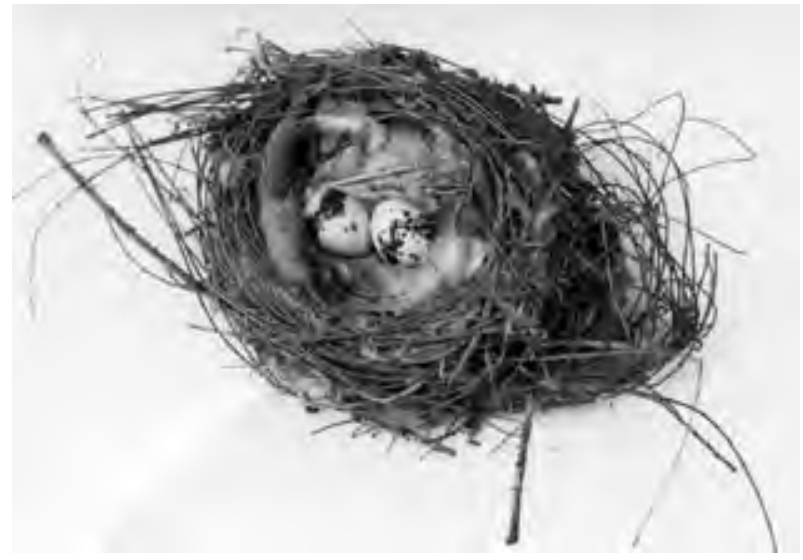

Figure 97. Pyrocephalus rubinus: nests with clutch. 
31/01/1964. Near Chiclayo, Lambayeque: Two fledglings perching side by side on a Prosopis. Both parents are busy feeding the young and hunting in the neighbourhood.

Middle of June, 1969 Miraflores/Lima: Male feeding two young on a telephone wire.

24/06/1969. Lomas de Lachay, $70 \mathrm{~km}$ north of Lima, $400 \mathrm{~m}$ : Male with two fledglings in a group of Caesalpinia.

03/05/1970. La Molina/Lima: Nest with clutch in a long row of old willows, growing along an irrigation-channel. It is situated about 2,5 $\mathrm{m}$ high on a dry horizontal branch. The densely woven nest consists of twigs, stems, vegetal fiber, grassroots and cotton. The interior is padded with feathers and wool. Measures: Inner diam. $5-5,5 \mathrm{~cm}$, outer diam. $8-9 \mathrm{~cm}$, height $4,5 \mathrm{~cm}$, depth $3 \mathrm{~cm}$. The two eggs are whitish. Light grey as well as light and dark brown splatters are arranged around middle part; small stains on rest of the surface. Measures: $15 \times 20 / 14 \times 19 \mathrm{~mm}$. Nest later abandoned (Fig. 98).

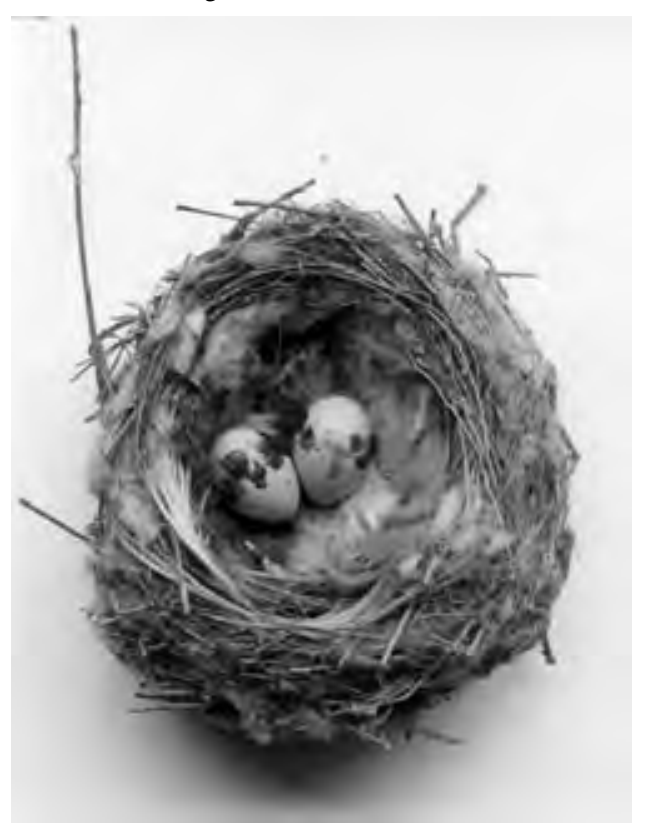

Figure 98. Pyrocephalus rubinus: nests with clutch.

06/03/1972. Cochabamba, Rio Chotano, Cajamarca, 1600 m: Dark brown ad. feeding two fledglings on a pacay tree.

Miraflores/Lima: Breeding behavior of a couple of P. rubinus. The nest is situated 5-6 m high on a horizontal branch of a tipa tree, not yet fully covered with leaves. Both ads. are sooty morphs. As only the lighter coloured ind. is breeding, I suppose it is the female.

05/11/1972, 13:30-15:00 (summary of protocol): During the observation period the breeding female was fed five times by her partner. She normally recieved the food sitting on the nest. Occ. she left the nest at the moment, when the male was approaching. The food was then delivered some meters away. The nest was occupied by the female during a total of $56 \mathrm{~min}$., each 'session' lasting 2 to $12 \mathrm{~min}$. She left the nest 9 times. During her absence, the male kept occ. an eye on it. Returning to the nest, the female did not always sit down immediately on the eggs, but paused on the rim of the nest, covering it with her rear part and tail. On one occ. she dedicated herself during 5 min. to preening. During the whole period she often changed position. Occasionally she poked her bill vigorously into the nest (a kind of 'maintenance'?). During the last $30 \mathrm{~min}$ the male did not show up (Fig. 99).

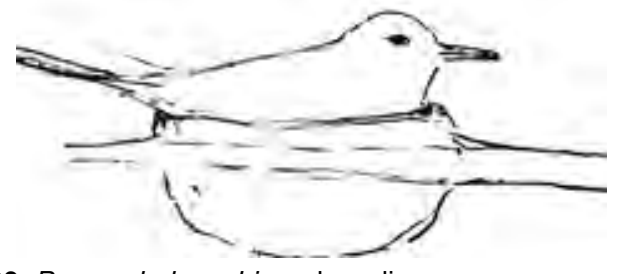

Figure 99. Pyrocephalus rubinus: breeding.
10/11/1972, 17:00-18:00 (summary of protocol): In the meantime, the young had hatched. Though not visible, I assume that there were two of them, as in all other recorded cases. During $22 \mathrm{~min} .(8+14)$ the nest was occupied by the female. Eight feedings have taken place, in five opportunities the food was supplied by the male and directly given to the young. On two occ. the food was first presented to the female, who - standing on the rim of the nest - immediaetly passed it on to the young. Three times fecal sacs were delivered and swallowed by the parents.

\section{Knipolegus aterrimus}

29/07/1968. La Mejorada, Mantaro Valley, Huancavelica, 2800 m: Ind. in an orchard, making sallies from a small tree. It snatches its prey in the air or from the ground.

17/06/1968. Orongoy, Pampas Cañon, Ayacucho, 2500 m: Ind. in montane scrub.

21/07/1976. Limatambo, Cusco, 2500-700 m: Several sightings from lush valley bottom to slope of montane scrub interspersed with trees. - Male perches on small, bare tree. Display flight: Performing an acrobatic loop, it displays its white wing bars. Song given during loop sounds like trew'TSWEW. It jumps 1-1,5 m into the air, performing about two sallies per minute. Meanwhile, another male is singing nearby.

06/07/1993. Pallar near Huamachuco, La Libertad, 2400 m: Ind. in montane scrub.

\section{Muscisaxicola flavinucha}

Austral migrant

29/06/1969. Between Comas and Concepción, Junín, 4400 m: Several ind. in Puna grassland.

07/07/1979. Cañete Valley, Lima/Junín, 4500 m : In Puna grassland.

\section{Muscisaxicola macloviana}

\section{Austral migrant}

24/09/1963. Lomas de Atocongo, Lima, 400 m: In small groups feeding in lush herbaceous vegetation.

27/08/1967. Lomas de Pacta, 45 south of Lima, $400 \mathrm{~m}$ : Two loose groups on hilltop with sparse vegetation.

14/081968. Lurin Valley, Lima, 100 m: Group of a dozen inds. in a barren field.

25/08/1968. Same place: Scattered inds.

30/08/1968. Mala Valley, Lima, $100 \mathrm{~m}$ : Several inds. in a freshly plowed field, thriving with prey.

02/10/1970. Chala, Arequipa: Ind. on the beach.

26/07/1988. Urbanización California, Chosica, Rímac Valley, Lima, $800 \mathrm{~m}$ : Ind. on barren land with scattered irrigated plots. Uses rocks as an outlook to chase insects, alternately hopping, running or flying for a short distance.

\section{Myiotheretes striaticollis}

\section{Sightings/Habitat}

NP: San Andrés de Cutervo, Cajamarca, 2400 m; Hacienda Chuquizongo, Chicama Valley, La Liberatd, 1700 m; Hacienda Cochabamba, Rio Chusgón, La Libertad, 2500 m.

CP: Lima: Locally common in the tributary valleys of Rio Rímac (Tapicara, San Bartolomé, Surco, Matucana) between 2200 and 3000 $\mathrm{m}$, in dry montane scrub and humid montane forest; Huaura Valley, $2700 \mathrm{~m}$.

Voice.- Three syllable song: pee'BEE'wee; one syllable calls: pew, hew or ewt.

12/06/1966. Zárate, Rímac Valley, Lima, 3000 m: Ind. flying from tree top to tree top, hunting insects in the air. 
16/03/1972. San Andrés de Cutervo, Cajamarca, 2400 m: Ind. on the edge of humid montane forest. Perches on tree tops, tree stumps or stones in pasture land. Raises occasionally its crest. Hunting also during rainfall.

\section{Polioxolmis rufipennis}

30/07/1966. Laguna Sausacocha north of Huamachuco, La Libertad, $3100 \mathrm{~m}$ : Several inds. perching on low scrub at lake side picking up insects off the ground.

29/09/1970. Slopes of Nevado Sarasara, Ayacucho, 3700 m: Solitary or in pairs in light Polylepis forest perching on top of trees. Feeding on insects, they fly in most cases down to the ground; exceptionally they capture their prey in the air.

29/08/1971. Pisco/ Huaytará Valley, Huancavelica, 3600-700 m: Several inds. present in a very limited area of montane scrub. Two or three at a time are 'hanging' in the strong upcurrent over the slope. Others are perching on top of scrubs or cacti. When hovering, some ind. turn abruptly away, in order to pursue and capture prey in the air. (According to BP, Prufipennis captures prey exclusively off the ground).

\section{Tumbezia salvini}

16/12/1964. Hacienda Mallares near Sullana, Piura, 300 m: Ind. in a patch of Prosopis forest.

08/01/1966. Near Olmos on the road to Abra Porculla, Lambayeque, $600 \mathrm{~m}$ : Ind. in deciduous forest.

\section{Ochthoeca pulchella}

17/09/1963. Zárate, Rímac Valley, Lima, 3000 m: Ind. netted in a rock-strewn clearing at forest edge. Recorded at the same place: $12 / 06 / 1966$

\section{Ochtoeca rufipectoralis}

17/06/1968. Pampas Cañon, below Orongoy, Ayacucho, 2800 m: Ind. in dry montane scrub.

02/03/1972. San Andrés de Cutervo, Cajamarca, 2400 m: Ind. at the edge of humid montane forest. Catches insects in the interior of a tree, making short sallies. - Three inds. in second growth, chasing each other.

\section{Ochthoeca fumicolor}

06/06/1967. Chiuchín, Huaura Valley, Lima, 2600 m: Ind. in riparian vegetation with Alnus. According to M. Koepcke first sighting in Lima. Characteristic feature: two rufous wing bars, absent in similar Ochthoeca oenanthoides. BP mentions for west slope only "northwest".

31/07/1976. Baños Yumagual, Jequetepeque Valley, Cajamarca, $2800 \mathrm{~m}$ : Ind. in humid montane scrub.

\section{Ochthoeca oenanthoides}

Sightings/Habitat.- In Polylepis woods of CP: Laguna Yanganuco, Ancash, 3700-900 m; Huaura Valley, Lima, 3800/4300 m; Chumcha, Santa Eulalia Valley, Lima, 3900-4200 m. Also in Eucalyptus grove: Baños, Chancay Valley, Lima, $3800 \mathrm{~m}$.

Behavior/Voice.- Perches on bushes or lower branches of trees. Song: ga'di'dada-di'dada.

\section{Ochthoeca leucophrys}

\section{Sightings}

NP: west slope $2800 \mathrm{~m}$; east slope $2400-3500 \mathrm{~m}$.

$\mathrm{CP}$ : west slope: Most sightings between 2500 and $3500 \mathrm{~m}$; from dry montane scrub (with cacti) to humid montane forest and Polylepis wood. Max. alt. in coastal valleys: Huaura/Chiuchín 3400 m, Rímac/ Santa Eulalia 4100 m, Pisco/Huaytará 3400 m.

Min. alt. according to BP: $2400 \mathrm{~m}$. Sightings below $2000 \mathrm{~m}$ : Santa Eulalia Valley, Lima 1600/1700/1800 m; Rímac Valley, Lima 1800m; east slope $2800-3500 \mathrm{~m}$.
SP: west slope $3400 \mathrm{~m}$; east slope 2400-3500 m.

Behavior.- Catches insects in the air and on the ground. Perches low, rarely higher than $2 \mathrm{~m}$ on scrub, cacti, stones, stonewalls, hedges, solitary trees or trees at forest edge. Marks its presence with a dry kip or qyac while perching.

13/06/1965. Zárate, Rímac Valley, Lima, 3000 m: Fairely common in humid montane forest. Several sightings of two or three inds. chasing each other with considerable noise (courting activity?).

27/07/1968. Santa Eulalia Valley, $1600 \mathrm{~m}$ : Ind. in close proximity to Contopus cinereus, perching momentarily only $5 \mathrm{~m}$ apart. They ignore each other.

\section{Muscigralla brevicauda}

\section{Sightings/Habitat}

Coast: Lima, Ica; fields, pasture, fallow land, lomas (Atocongo), gramadales.

11/01/1968. Mouth of Rio Mala, Lima: Several inds. in pasture land and barren fields. Song: tsprew-tsprew...

15/01/1973. Puerto Viejo, $70 \mathrm{~km}$ south of Lima: Extensive gramadal with shrubbery. Display flight: Starting from a low scrub, ascends gently in an undulating flight singing intermittently. Returns to perch in silence (Fig. 100).

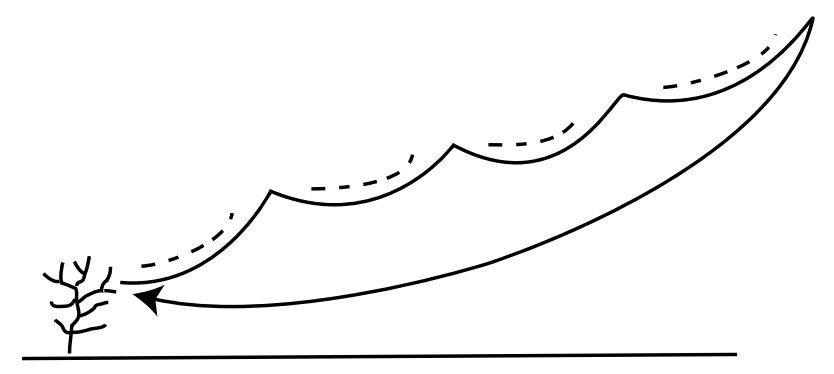

Figure 100. Muscigralla brevicauda: display flight: — flight --- song.

\section{Myiodynastes bairdi}

15-16/02/1964. Hacienda Mallares, near Sullana, Piura, 200 m: Ind. at the edge of cultivated land with scattered trees. - Several sightings in the Amotape Mountains, 600-800 m in deciduous forest.

\section{Myiodynastes maculatus}

16/02/1964. Sauce Grande, Amotape Mountains, Piura, 700 m: Ind. in deciduous forest.

28/07/1964. Near Juanjui, San Martín, 400 m: Pair on a tree in secondary growth.

20/01/1970. Research Station Panguana, Rio Llullapichis, Huánuco, $300 \mathrm{~m}$ : Ind. in secondary growth .

03/07/1972. La Merced, Chanchamayo Valley, Junín, 800 m: Ind. on a Cecropia trying to eat a big armored insect and eventually swallowing it wholly after banging it several times against the branch on which it perched.

05/07/1972. San Ramón, Chanchamayo Valley, Junin, 800 m: Ind. perching on an isolated tree, turning its head constantly in all directions, peering for prey. Catches insects in short sallies or gleans them from leaves and branches.

\section{Tyrannus niveigularis}

11/01/1964. Near Batán Grande, Lambayeque: Ind. at the edge of a Prosopis forest, hunting insects from exposed perches.

15-16/02/1964. Hacienda Mallares near Sullana, $300 \mathrm{~m}$ and Amotape Mountains, 800 m, Piura: Fairly common in deciduous forest.

\section{Myiarchus semirufus}

29/01/1999. Archeological site of Sechín near Casma, Ancash: Ind. perches on lower branches in extensive Prosopis forest. 


\section{Myiarchus tuberculifer}

\section{Sightings}

NP: west slope: Baños de Yamagual, Jequetepeque Valley, Cajamarca, 2800 m; Coina, Chicama Valley, La Libertad, 1600 m; east slope: San Andrés de Cutervo, Cajamarca, 2000/2400 m; Pataz, Marañón Valley, La Libertad, 2800 m; west of Rioja, San Martin/Amazonas, 1200m.

CP: west slope: Monterrey, Callejón de Huaylas, Ancash, 3000 m; fairely common in the coastal valleys of Lima (Huaura, Canta, Rímac/ Santa Eulalia) between 1500 and 3000 m; east slope: Rio Paucartambo, Pasco, 2600 m; San Ramón, Junín, 800 m.

Behavior/Voice.- Perches motionless in half-shade of bushes and trees, making short sallies in limited area. A melancholic, descending call contrasts with a cheerful three-note song which includes a high pitched last note.

20/07/1983. West of Rioja, San Martin/Amazonas, 1200 m: Ind. in primary forest with nesting material (probably down feathers).

\section{CotingIDAE}

\section{Zaratornis stresemanni}

Sightings/Habitat.- Restricted to two sites in Lima: The humid montane forest of Zárate, Rímac Valley, 2900-3100 m and the Polylepis wood of Chumcha, Sta. Eulalia Valley, 3900-4300m m (Fig. 101).

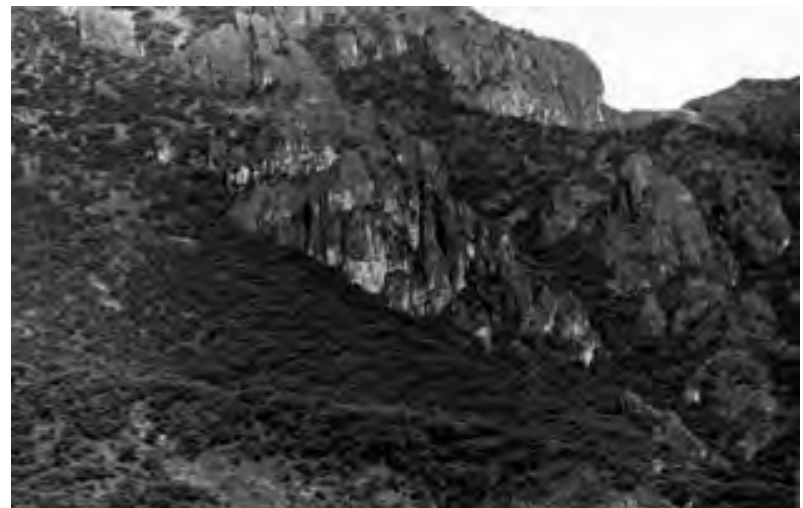

Figure 101. General view of Polylepis wood of Chumcha.

26/03/1966. Chumcha: First proof of $Z$. stresemanni at this site. M. and H.W. Koepcke collect the first male specimens. (In Zárate they had so far recorded only females). Several sightings between 3900 and $4300 \mathrm{~m}$; one in semi humid montane scrub at $3300 \mathrm{~m}$ (Fig. 102). - $Z$. Stresemanni likes to perch on top of Polylepis trees.

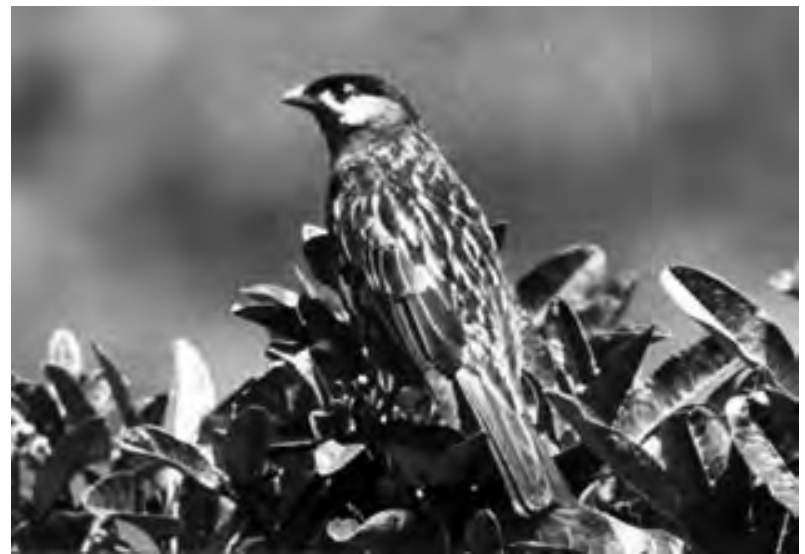

Figure 102. Zaratornis stresemanni.

26/04/1969. Chumcha: Sightings limited to the densest part of the forest: a u-shaped quebrada with creek. We observe 4 ind. regurgitating seeds of Phrygilanthus, a parasit plant which thrives on Polylepis. The seeds are deposited mainly on tree tops (photos). They form big lumps containing hundreds of seeds each. Occ. the seeds are distributed along branches. We found three of these deposits on tree tops only 10-20 m apart from each other (Fig. 105/106). Within 20 min. three inds. approach two of the deposits. A fourth ind. - probably disturbed by our presence - settles down on a Gynoxys, wiping off the seeds on a leaf. All four regurgitate in irregular intervals 2, 3 or 4 seeds consecutively. Sometimes the act proves to be arduous: By stretching the body into an upright position, the seed is finally thrown out only after a series of convulsive movements. - Warning call is emitted while perched at a seed deposit; it ends with a soft rattle.

24-25/04/1971. Chumcha: In the quebrada above described 14 sightings in two days; only one outside the main area; always on tree tops, only once two inds. together. Three records of inds. feeding on berries of Phrygilanthus, five inds. regurgitating. No sign of breeding behavior. Vocal emission during flight: khacceram'khac'khac. Ind. netted (Fig. 103/104).
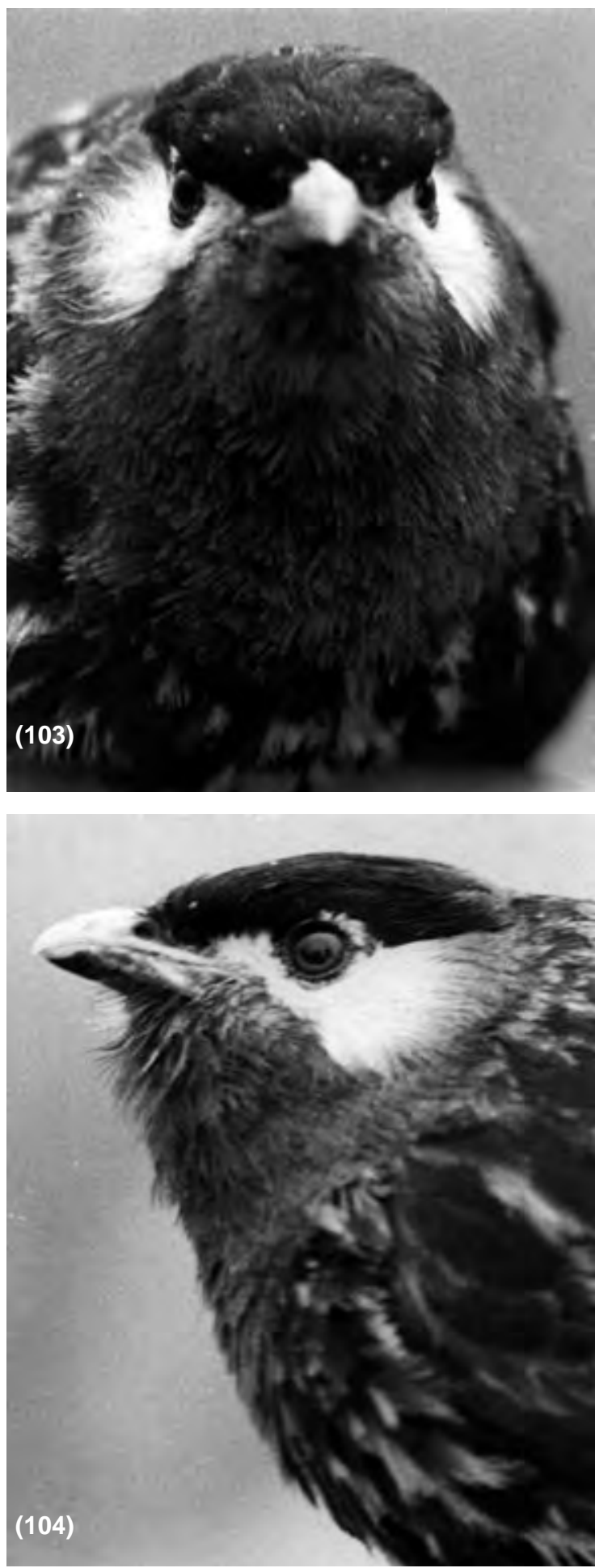

Figure 103-104. Zaratornis stresemanni. 


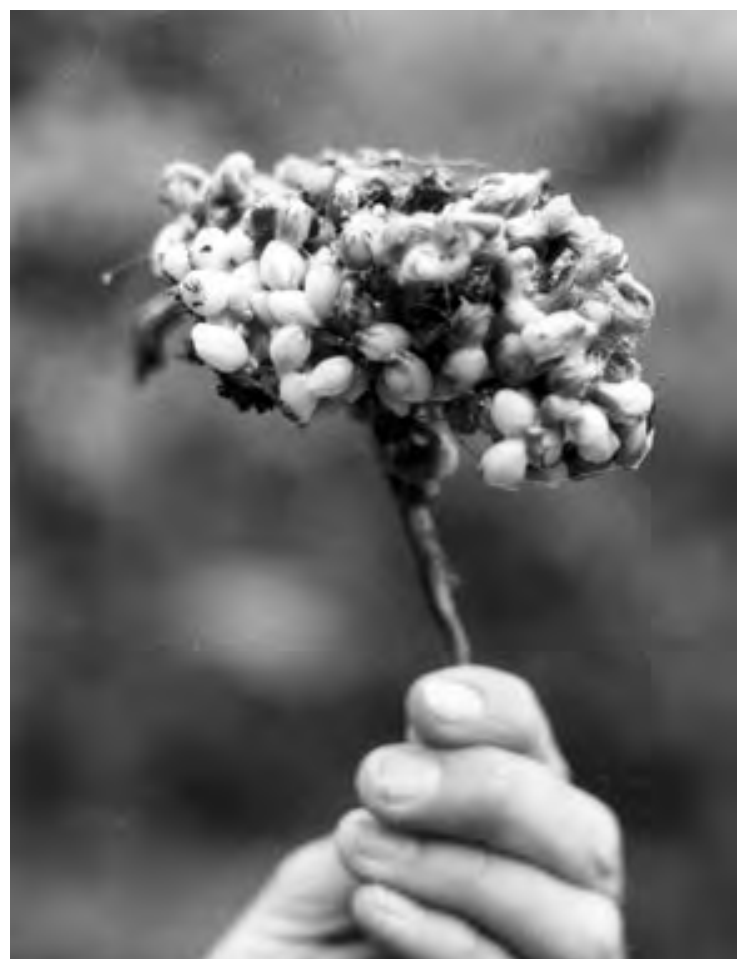

Figure 105. Zaratornis stresemanni. Large deposit of Phrygilanthus seeds.

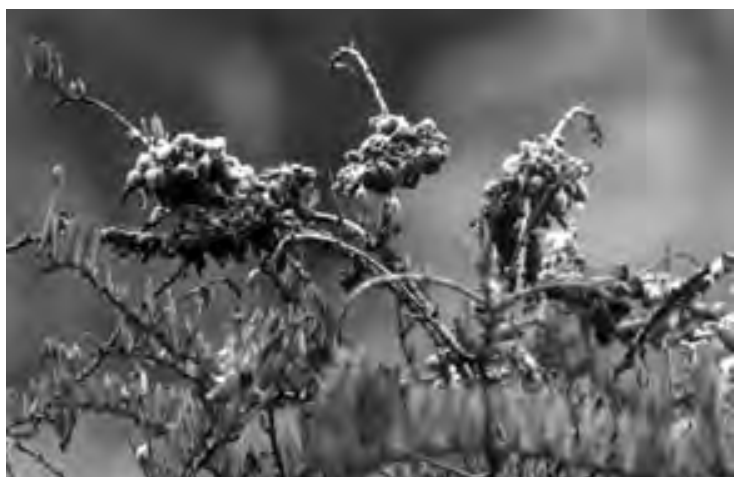

Figure 106. Zaratornis stresemanni. Phrygilanthus seeds deposited on Phrygilanthus.

\section{Ampelion rubrocristatus}

13/06/1965. Zárate, Rímac Valley, Lima, 3000 m: Several sightings; twice ad. with young on Oreopanax. Two inds. feeding on fruits on a bush, afterwards chasing each other, emitting angry calls.

16/06/1968. Between Mollebamba and Orongoy, Pampas Cañon, Ayacucho, $3500 \mathrm{~m}$ : Ind. in humid quebrada with dense vegetation (Gynoxys, Escallonia and other evergreen bushes and trees).

07/07/1968. Zárate: Ad. is followed by begging and chirping young. - Frog-like song: kwec'kwec'trac'trac'kwec ...

22-23/07/1970. Zárate. 3 ind. (only one at a time) appear at a well in a forest clearing. The well serves as drinking and bathing place for many other species of birds (Fig. 107).

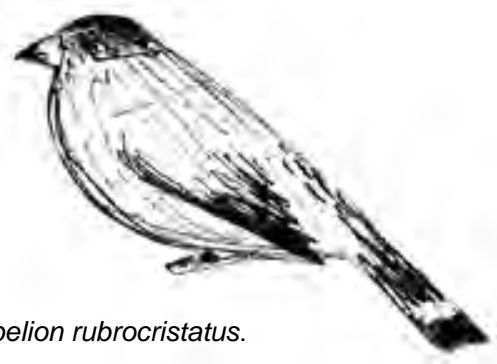

07/04/2003. Laguna Puruhuay, near Huari, Ancash, ca. 3500 m: Fairly common in lush vegetation (Alnus) at the lakeside and the torrential outlet. Often perching quietly on a tree top, alone or in pairs. Hunting foray or display flight (Fjeldsa 1990): Ind. ascends several times from a perch on a tree top 2-10 $\mathrm{m}$ into the air by depicting a gentle curve, then returns to the same place or another one nearby.

\section{Rupicola peruviana}

19/07/1983. Between Mendoza and Rioja, Amazonas, 1800 m: Narrow valley covered with humid montane forest, partially lined with cliffs. Male perched on a lower branch. He observes the obeserver attentively, constantly changing position. An occ. sunbeam brushing his back or crest produces a burst of bright orange. His hoarse call accompanies us for some time.

\section{TITYRIDAE}

\section{Pachyramphus albogriseus}

15/02/1964. Sauce Grande, Amotape Mountains, Piura, 650 m: Ind. collected in deciduous forest by W. Markl.

\section{CORVIDAE}

\section{Cyanolyca viridicyana}

16/07/1983. Tingo, between Chachapoyas and Mendoza, Amazonas, $2400 \mathrm{~m}$ : Two inds. in humid montane forest, communicating with each other at a distance of about $100 \mathrm{~m}$.

\section{Cyanocorax violaceus}

19/09/1967. Rio Marañón near mouth of Rio Cenepa, Amazonas, ca. $300 \mathrm{~m}$ : Several sightings, mostly 2 or 3 inds. together, calling.

\section{Cyanocorax mystacalis}

Sighted in Tumbes, Piura and Lambayeque in Bombax and Prosopis forest; fairly common in deciduous forest; protesting noisily when disturbed.

08/01/1966. Hacienda San Jacinto, Piura: Common in garden; food-carrying ind.

\section{Cyanocorax yncas}

January 1967. Rio Chamaya, Cajamarca, 700 m: Group of 5 inds. in riparian scrub.

02-03/08/1966. Aricapampa, Marañón Valley, La Libertad, 2400 m: Common in quebrada with creek and lush vegetation. In the evening $(5.30 \mathrm{pm})$ they leave the quebrada, ascending the dry, scrub-covered slopes in pairs or small groups, calling constantly, either a high pitched kyakya (popular name Quiénquién) or a low pitched kyew'kyew resembling a hoarse horn. Also to be seen and heard in the morning between 7 an $8 \mathrm{am}$.

20-22/01/1968. Yaupi, Rio Paucartambo, Pasco, 1500-2000 m. Fairly common in humid montane forest and secondary growth; curious and noisy.

15/07/1983. Mendoza, Amazonas, 1600 m: Relics of humid forest surrounded by second growth and pasture land. Attracted by my presence, two ind. come hopping down from a tree top until reaching the lower branches, eying me curiously at a distance of about 10 $\mathrm{m}$. By emitting a variety of noisy sounds, they gradually attract five conspecific inds. They hop and bob around exitedly during about 10 min., demonstrating their rich vocal repertoire.

19/07/1983. Pucatambo, Amazonas/San Martin, west of Rioja, $1500 \mathrm{~m}$ : Very similar behavior in similar habitat as described above.

15/04/2005. Between Balsas and Abra Barro Negro, Amazonas, ca. $2500 \mathrm{~m}$ : Ind. in humid montane scrub with trees.

\section{HIRUNDINIDAE}

\section{Pygochelidon cyanoleuca}

\section{Sightings}

NP: west slope: Lambayeque sealevel, La Libertad 1500 m; east slope: Cajamarca 1600-2600 m, Amazonas 300/2300 m, La Libertad $1200 / 2400 \mathrm{~m}$. 

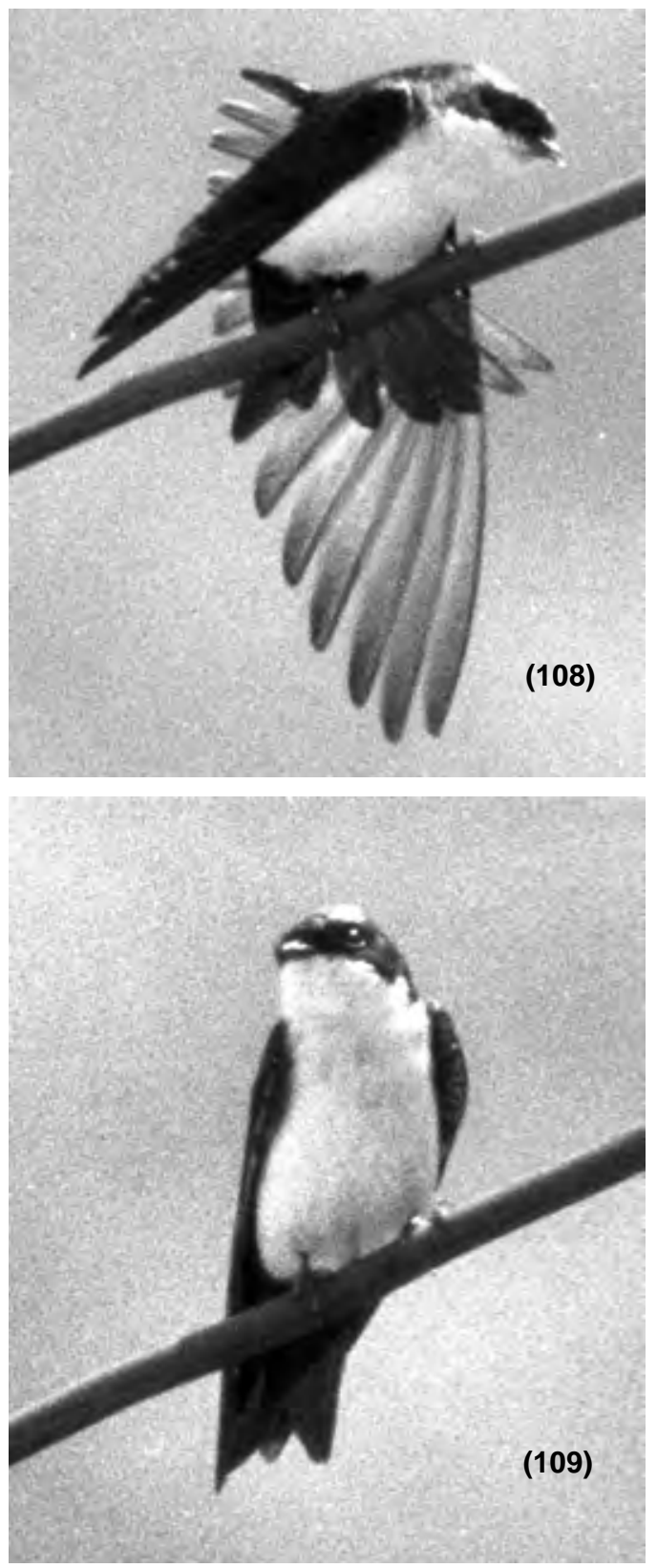

Figure 108-109. Pygochelidon cyanoleuca.

CP: west slope: mainly coastal plain 0-300 m; max. alt. Lima 2500 m; east slope: Ancash 3200 m, Huánuco 500/2700 m, Pasco up to $2500 \mathrm{~m}$; Junin 1000-2200 m.

SP: east slope: Cusco $2400 \mathrm{~m}$.

27/11/1963. Chilca, $60 \mathrm{~km}$ south of Lima: Hunting in large numbers over brack-water lagoons and over the beach. The slope of a nearby sand-dune serves as gathering point and resting place. There is a constant coming and going. - Nest-building on a crumbling cliff only a few steps from the shore about $6 \mathrm{~m}$ above the ground. Some protruding stems mark the nesting place in a crevice. Ind. arriving several times with nesting material, in one occ. with a down, that it had picked up on the shore.

17/12/1966. La Victoria/Lima: Nest-building in an unfinished house. Ind. disappears with a long grass stem in a crevice in the wall. Same activity observed over the following days.

12/09/1967. Chiriaco, Amazonas, 300 m: Hunting over the Rio Chiriaco in company of Atticora fasciata, Tachycineta albiventer and Progne tapera.

February 1968. Miraflores/Lima: Large number gathering at different occ. on two telephone wires crossing the school yard. The 100-200 inds. chirp and chatter all the time, restlessly coming and going. On one occ. a certain number settles temporarily on the pavement, busily pattering around.

25/08/1968. San Juan de Dios, south of Lima: Hunting in large numbers over a large waste water reservoir in the desert. Several breeding holes on the banks of a $2 \mathrm{~m}$ deep erosion channel. No breeding activity.

11/02/1970. Tambo de Mora, Ica: Several breeding holes in a cliff at the edge of the culitavted area. No breeding activity (Fig. 110).

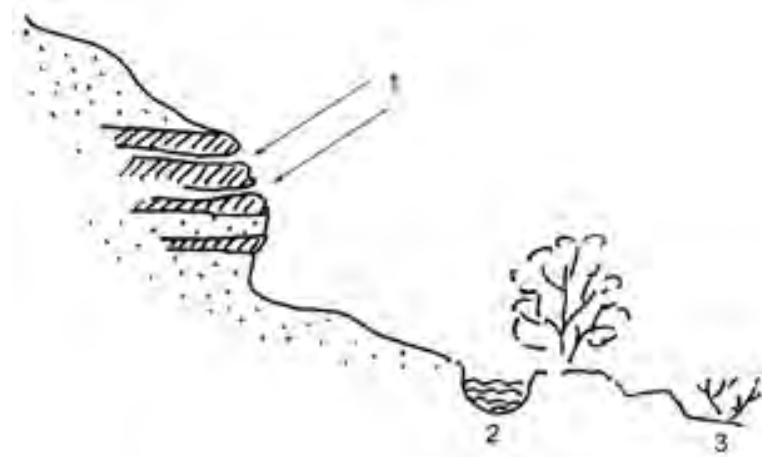

Figure 110. 1: Entrance of nesting holes 2: irrigation channel 3 : cotton field.

02/01/1972. Miraflores/Lima: Unusual gathering of about 100 ind. in the air. They behave excitedly and confused. Reason: A Falco peregrinus is circling nearby. As soon as the enemy is out of sight, the flock disbands.

17/12/1972. Miraflores/Lima: A pair of Buteo platypterus are circling low over a group of Eucalyptus trees. A tense flock of P. Cyanoleuca follows them at a respectful distance. Occ. an ind. breaks away from the group to harass the pair, shooting past them very closely.

17/02/1999. Huacachina, Ica: Nest with fledglings in an open garage placed on a dangling part of reed mats. Both ads. participate in the feeding.

\section{Orochelidon murina}

\section{Sightings}

NP: west slope: La Libertad 1500 m; east slope: Cajamarca 2600 m, La Libertad 2400/2500/3300 m.

CP: west slope: Lima 1000-4300 m; east slope: Ancash 2600-3400 m, Huánuco $3000 / 3400 \mathrm{~m}$, Pasco 2500/3000 m; highest frequency in $\mathrm{CP}$ between 2000 and $3500 \mathrm{~m}$.

South Peru: east slope: Cusco 2400/3000/3500 m.

$\mathrm{BP}$ indicates $2200 \mathrm{~m}$ as min. alt. Sightings below $2200 \mathrm{~m}$ : Chicama Valley, La Libertad, 1500 m; Huauara Valley, Lima, 1000 m; Santa Eulalia Valley, Lima, 1700/1800 m.

15/09/1963. Zárate, Rímac Valley, Lima, 3000 m: O. murina appears in large numbers, as soon as the sun rays reach the forest (about $8 \mathrm{am}$ ), at the same time large clouds of mosquitoes begin to fill the air.

01-02/11/1963. Santa Eulalia Valley, Lima, 1800 m: They appear at about $4.30 \mathrm{pm}$ sharing the rich hunting ground - pasture land and riparian vegetation - with Aeronautes andecolus, flying 1-10 m above the ground.

03/10/1964. Santa Eulalia Valley, Lima, $1700 \mathrm{~m}$ : Hunting in the afternoon along with Aeronautes andecolus. Mosquitoe plague!

02-07/02/1965. Casta, Santa Eulalia Valley, Lima, 3100 m: Hunting daily over the village. Probably breeding beneath the corrugated iron roof of an adobe building.

31/10 - 01/11/1965. Santa Eulalia Valley, Lima, 2600-4200 m: Several small flocks at different altitudes. Between 10 and 12 am hunting over Polylepis wood of Chumcha. 
02-03/08/1966. Aricapampa, Marañón Valley, La Libertad, 2400 $\mathrm{m}$ : Hunting all day long over a lush quebrada and adjacent montane scrub in company of Pygochelidon cyanoleuca. At dusk they disappear and leave the place to the bats (with no temporal overlapping).

03-04/12/1966. Chumcha, Santa Eulalia Valley, Lima, 3400 m: Shortly after sunset, a flock of 10-20 inds. gather on a small protrusion of a cliff warmed up by the sun. First they tidy up, then fluff themselves and some put their head into the plumage in a typical sleeping position (Fig. 111).

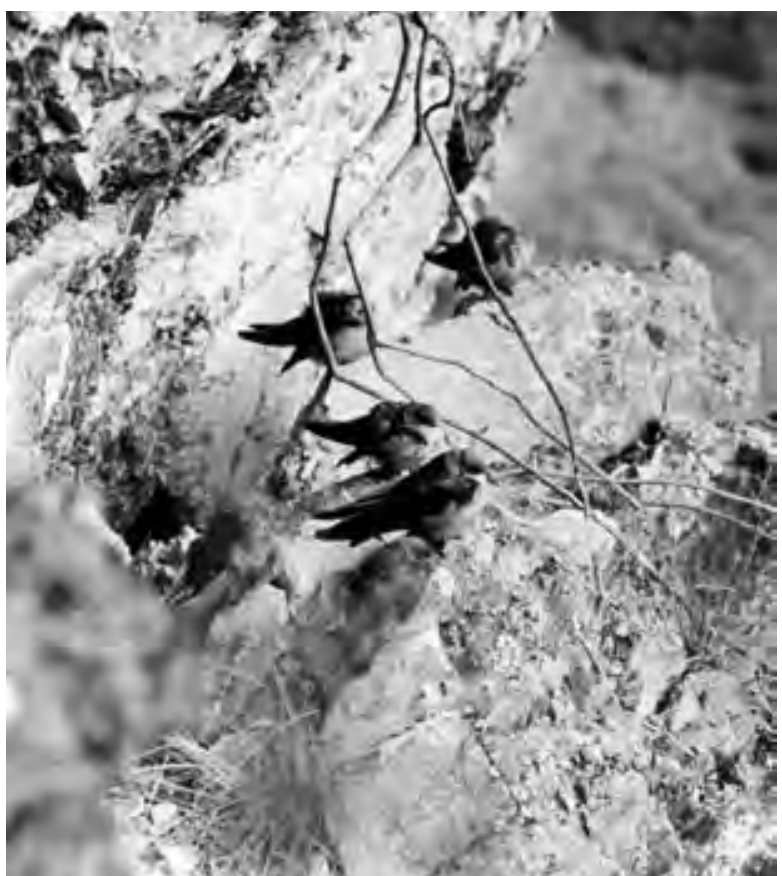

Figure 111. Orochelidon murina roosting.

01-08/09/1972. Casta, Santa Eulalia Valley, 3100 m: At daytime, they hunt over the village. In the evening, between 8 and $8.30 \mathrm{pm}$, they gather at the school house to spend the night beneath the iron roof. They leave the place in the morning between 6.30 and $7.00 \mathrm{am}$. Before they start hunting, they stay for a while on the edge of the church wall, probably to warm up.

06/04/2003. Baños de Chavín, Ancash, 3300 m: Hunting in the morning over the stream. Several inds. aproach again and again a nesting place in a horizontal crevice in a cliff about $7 \mathrm{~m}$ above the stream. Two ind. arrive with nesting material. One of them comes up with a piece of moss, the other with a long grass stem. The lively coming and going suggests, that there are also young to be fed (Fig. 112).

\section{Orochelidon andecola}

01/10/1970. Parinacochas, Ayacucho, 3400 m: Numerous over the heath-like grassland at the foot of Nevado Sarasara. Breeding holes in an about $8 \mathrm{~m}$ high earth wall along a stream. The activity around and

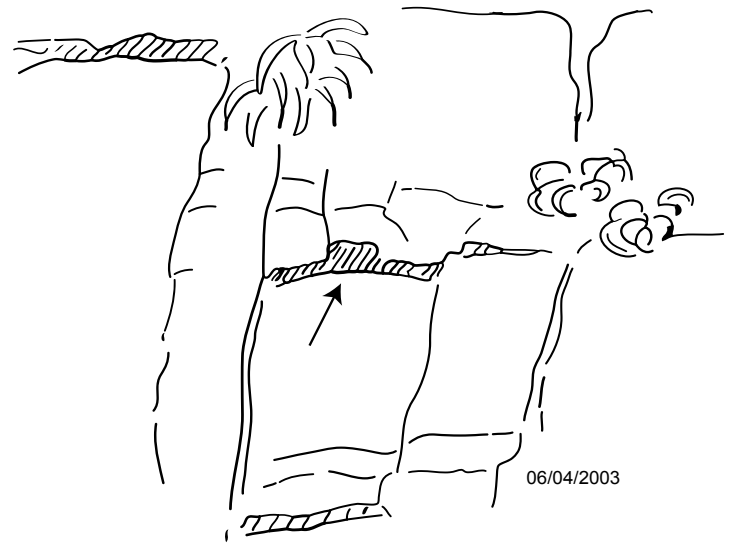

Figure 112. Orochelidon murina: nesting site in a cliff. at the holes suggests the beginning of the breeding season. On one occ. three ind. in a row leave the same hole.

\section{Progne murphy}

18/10/1964 - 09/12/1964 - 29/12/1967. Puerto Viejo, 70 km south of Lima: Pair hunting over the marshland with small lagoons.

09/08/1971. Playa Culebras betw. Huarmey and Casma, Ancash: Male and three females (or immatutres?) hunting over a restricted area: They steep dive onto the beach, dashing along close to the ground, then turn back to repeat the manoeuvre.

\section{Hirundo rustica}

\section{Boreal migrant}

Sightings.- Coast of Lima: Earliest record 11.09.: Lomas de Lachay; latest record 11.05.: Totoral de Villa. Highest concentration of sightings in Oct/Nov: 15 of 32 overall records. Part of the recorded birds were possibly on their way further south. Some flocks registered in Mar/Apr (8 records) were probably on their return flight.

Habitat.- Cultivated land, lomas, totorales, brack water lagoons, waste water reservoirs, river mouths, beaches, giant garbage dumps south of Lima $(1965 / 66)$.

26/10/1963. Totoral de Villa, south of Lima: Hunting in great numbers over the marshland. Towards $6 \mathrm{pm}$ additional flocks appear obviously preparing to leave for their (unknown) roosting place.

22/11/1966. San Juan de Dios, south of Lima: Flocks of 20-30 inds. hunting over fields and waste water lagoon. They rest temporarily in great numbers on the slope of a sand dune. There is a busy coming and going.

16/01/1966. Near Piura: Very numerous hunting over natural lagoon and totoral. At sunset they gather on the nearby sandy ground as a close flock.

\section{Petrochelidon rufocollaris}

18/11/1972. Chancay Valley, Lima, $400 \mathrm{~m}$ : Nesting colony under the roof of an adobe house Fig. 113/114. The flat roof made of caña brava is about $3 \mathrm{~m}$ above ground and protrudes $1.50 \mathrm{~m}$. The colony,
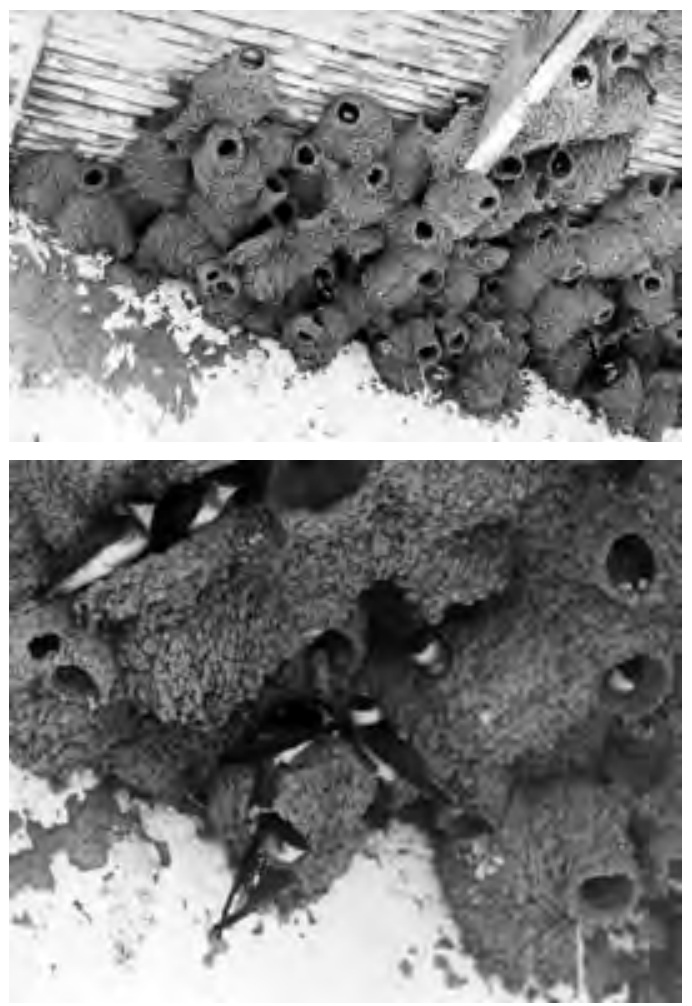

Figure 113-114. Petrochlidon rufocollaris: nest-building activity in a breeding colony. 
counting about 200 nests, is getting prepared for the breeding season: New nests are added to the old, partially decayed ones. Sitting in the middle of their nests, the birds are adding horizontal layers by stringing together bits of mud. The constructing activity is accompanied by a constant twitter and chatter. The pear-shaped nests are $15-20 \mathrm{~cm}$ long. The rimmed entrances measure about $4 \mathrm{~cm}$ in diam. The interior, as some decayed nests reveal, consists of feathers, straws and strings. A Passer domesticus is inspecting some unfinished nests, undisturbed by Prufocollaris.

\section{TROGLODYTIDAE}

\section{Troglodytes aedon}

The following records refer - if not declared otherwise - to the districts of La Victoria/Lima and Miraflores/Lima.

Habitat/Behavior.- Ubiquitous; perfectly adapted to the urban habitat. Feeds on a broad variety of invertrebrates that thrive in parks, gardens, beneath roofs, on walls, within the dense foliage of climbers and the cracked bark of trees. As nesting site T. aedon setteles for any kind of niche, hole or cavity; the only condition: to provide sufficient protection to its offspring.

\section{Voice:}

a) A conspicuous, vigorous and melodic song, "a cascade of liquid notes". It normally lasts $2-5 \mathrm{sec}$ interrupted by short intervals. At the height of courting activity a sequence may last up to $25 \mathrm{sec}$. The short intervals may be filled with a soft twittering. T. aedon is a tireless singer. In summer it starts between 5.00 and $5.30 \mathrm{am}$, in winter an hour later. The song is emitted from an elevated site like a telephone or a light pole, a television antenna, a wall, a fence or the edge of a house.

b) A rolling, repeated rreb'rreb; with this often emitted call (e.g. while foraging). T. aedon signals its presence or expresses a kind of warning to all potential trespassers.

c) A sharp, penetrating pseépsee, expresses alarm, provoked - in most cases - by a cat. With this call, it approaches the enemy to arms length, trying to chase it away form its nesting site or some careless fledglings.

The diagram shows, that courting and reproduction activity takes place all year round. However it permits the distinction of two main breeding periods. One cycle begins at the end of Nov and ends in mid Apr, the following starts at the end of May and lasts till mid Oct.

Reproductive periods of Troglodytes aedon

\begin{tabular}{|c|c|c|c|c|c|c|c|c|c|c|c|c|}
\hline & 1 & 2 & 3 & 4 & 5 & 6 & 7 & 8 & 9 & 10 & 11 & 12 \\
\hline $\mathrm{s}$ & $\cdots$ & & &,-- & $\ldots$ & $\cdots$ & & - & - & $\because$ & , & $\cdots$ \\
\hline $\mathrm{n}$ & & & - & & & & 1 & & & 1 & 1 & 1 \\
\hline b & & & - & & & & & - - & & | & & - \\
\hline $\mathrm{fn}$ & | & & -- & - & & -.. & -- & & & & & - \\
\hline fo & 1. & & | & & & & -- & | & -- & - & & 1 \\
\hline
\end{tabular}

Figure 115. 1-12: month/year s: song activity $n$ : nest-building $b$ : breeding fn: feeding at nest fo: feeding outside nest | single record --- observation period.

Nest-building.- The male is known to start several nests at a time. He stuffs any suitable cavity with nesting material. It's up to the female to inspect the unfinished nests and to finally choose the 'home' of her preference. The following records are related to the nest selection ritual:

05/09/1964. The ritual takes place in a large building of the ancient "terminal terrestre": A female, carrying a narrow leaf in her bill, perches high up in a window opening. She is approached by a male singing fervently. The female now flies on to the next window, followed closely by the male - and so on.

\section{5/10/1965. See Breeding records g)}

July 1972. Male singing in the garden, wings quivering. When the female appears, he withdraws a short way, followed immediately by his mate. The male moves forward, the female follows him, then both disappear. After $10 \mathrm{~min}$. they show up again: Ahead the female, wings trembling, with a warning rreb'rreb, followed by the singing male. The male withdraws again, the female follows him.

\section{Breeding records}

a) $28 / 05-26 / 06 / 1963$

28/05/1963. Clutch of 3 eggs in a store of sports equipment protected by wire mesh (Fig. 116). The bottom of the nest consists mainly of piled up twigs (up to $18 \mathrm{~cm}$ long) and grass stems. It also contains feathers (up to $9 \mathrm{~cm}$ long), cotton (next field about $500 \mathrm{~m}$ away), some leaves, a horse hair ( $45 \mathrm{~cm}$ long), spider web, a piece of Papyrus, many scraps of paper and plastic (schoolyard!), some threads and a string ball of a total length of $65 \mathrm{~cm}$. - Eggs: creamy with brown speckles, that concentrate collar-like around broad pole. Measures: $13,5 \times 17,5 / 13,5 \times 18,5 / 13,5 \times 18 \mathrm{~mm}$.

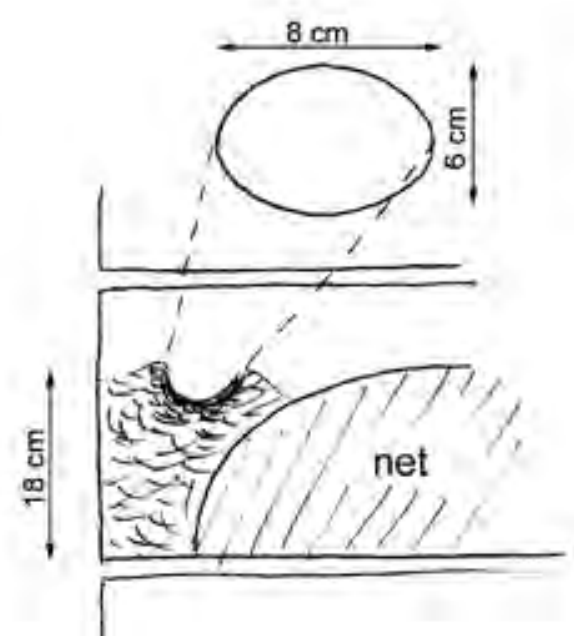

Figure 116. Troglodytes aedon: nest in a store of sports equipment.

10/06/1963. Male perched on a small tree near deposit, singing. He approaches the nesting site step by step, singing continuously, even within the concealed nest.

11/06/1963. Two fledglings hatched, third egg sterile. Duration of breeding: 16-18 days. One of the ads. stays for some days with the young, to protect them. - One week old, they emit their first begging sounds. Both parents take part in the feeding. On one occ. both ads. arrive at the same time. One of them delivers its prey to the young, then recieves the food from its mate and passes it along to the young. Departing ad. occ. carries away fecal sacs.

26/06/1963. The two young have left the nest. Feeding period: 15 days.

b) 19/12 - end of December 1963.

$19 / 12 / 1963$. Nest-building beneath the roof ridge of the above mentioned store (Fig. 117). Ind. carrying nesting material.

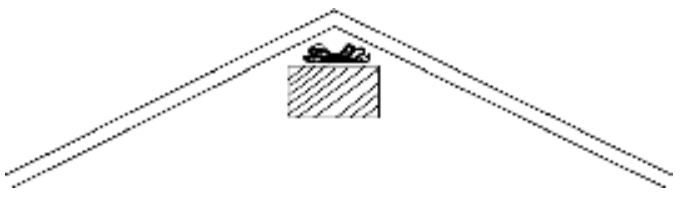

Figure 117. Troglodytes aedon: nest beneath roof.

End of December 1963. Male sings in the vicinity of the store. Occ. the song is replaced by an intense twittering accompanied by trembling wings, a behavior that is part of the nest selection ritual.

c) End of December 1963. An old nest in the cavity of a wooden garden door is stuffed with new material (Fig. 118/119).

ca. 29/12/1963. Deposition of 3 eggs. The ads. seem irritated by the two different positions of the door: it is shut at night and open during the day. On one occ., one of the ads. 'attacks' the car, when it passes the door. Clutch later abandoned. 


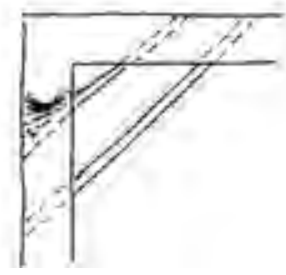

Figure 118. Troglodytes aedon: nest in wooden garden door.

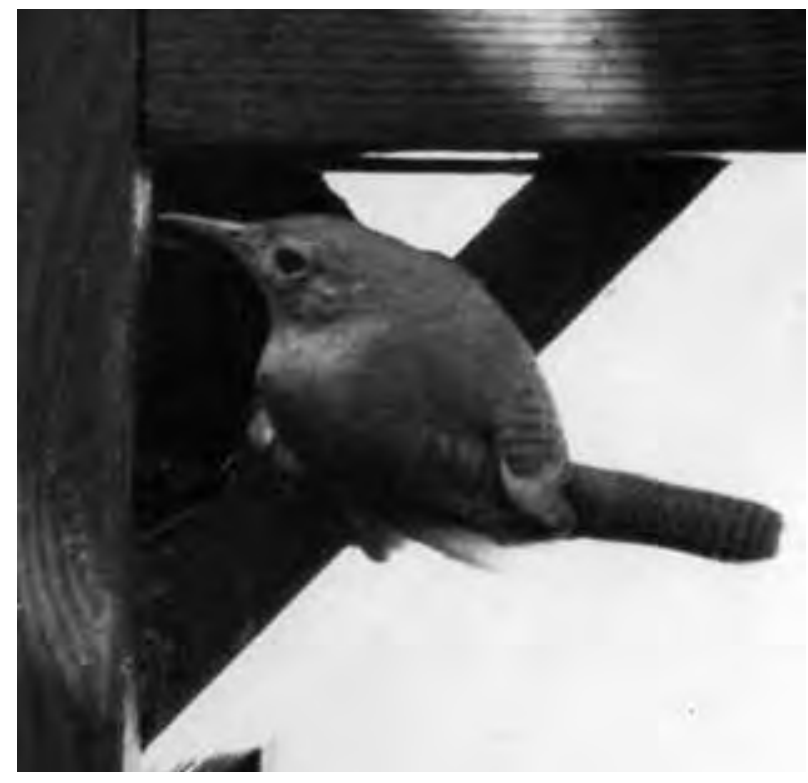

Figure 119. Troglodytes aedon: arriving at nest.

d) $01 / 03-17 / 03 / 1965$.

01/03/1965. Clutch of 4 eggs in garden door $(\rightarrow c)$.

07/03/1965. Ad. arrives with winged insect.

10/03/1965. Female leaves nest, returns after some minutes with downy chicken feather. Meanwhile, male approaches nest, hopping and running along garden wall, singing vigorously.

$12-17 / 12 / 1965$. Both ads. take part in feeding activity. In one occ., the incoming ad. passes food to its 'sitting' mate.

e) Mid July 65. Brood in a flood light at the edge of a tennis court, about $8 \mathrm{~m}$ above the ground. Some feedings recorded; also the disposal of fecal sacs.

f) $06 / 10 / 1965$. Clutch of 3 eggs in wooden garden door $(\rightarrow c, d)$.

\section{g) $25 / 09 / 1965$ - 01/01/1966.}

Mid September. A segment of bamboo is offered to T. aedon as nest box. It is placed near the garden wall, half concealed by a climber, $1.20 \mathrm{~m}$ above the ground. It is $35 \mathrm{~cm}$ long and $10 \mathrm{~cm}$ wide and it has a removable cover (Fig. 120).

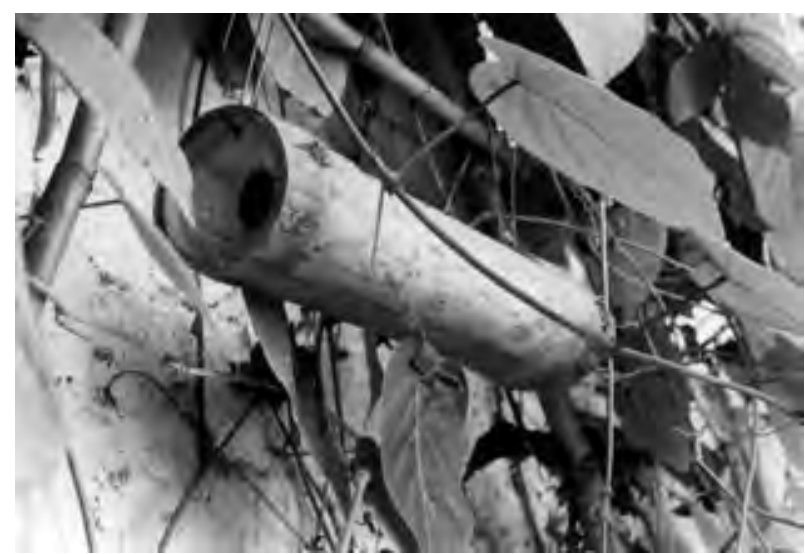

Figure 120. Troglodytes aedon: piece of bamboo serving as nest box.
$25 / 09 / 1965$. The rear part of the bamboo box is nearly filled with loose nesting material. In the front part, a hollow becomes discernible.

$15 / 10 / 1965$. Male settles on the garden door and starts to sing immediately, followed closely by a female, carrying a white down feather. The male moves towards the nest box, pausing on the door pole, then on the fence, followed by his mate. Without further ado, both disappear in the box, from where an intense twittering can be heard. Both leave the box shortly afterward.

Second half of Nov After a pause of about 4 weeks, the nest-building is taken up again. The hollow is now very deep and furnished with soft chicken down.

27-28-29/10/1965. Two eggs are deposited between 27. October at 10.00 am and 28 . Oct at $9.30 \mathrm{pm}$., the third egg between 28 . Oct at $9.30 \mathrm{pm}$ and 29 . Oct $7.30 \mathrm{am}$. Breeding starts, when clutch is complete (Fig. 121). - During breeding time, male sings nearly every morning (recorded as early as $5.15 \mathrm{am}$ ).

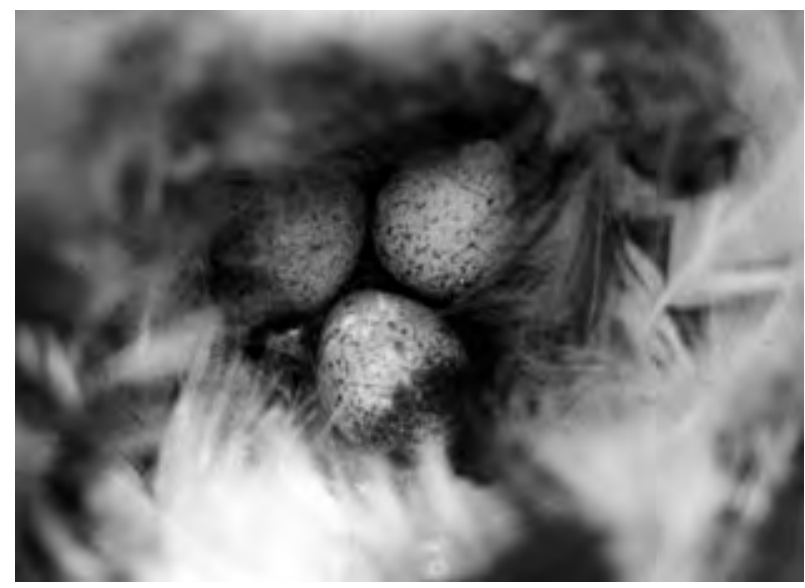

Figure 121. Troglodytes aedon: clutch in nest box.

14/12/1965. All three fledglings have hatched between 7 am and $6 \mathrm{pm}$. They are completly naked, except for some hairs on their head. They look like pink cock-chafer grubs.

15/12/1965. $2^{\text {nd }}$ day (summary of protocol): 15:40-16:40

Both ad. participate in the feeding. In 60 min they make 17 visits, or one feeding every 3-4 min. In 6 different 'sessions' one of the ads. stays with the young during a total of $20 \mathrm{~min}$. They do not leave the box before having assured themselves that there is no undesirable witness around (Fig. 122). If one ad. arrives at the box, while the other one is guarding the young, it passes the food on to its mate. Occ. it waits for the partner to leave. The portions of food vary considerably. They consist of one or several pieces of prey: winged insects, larvae, caterpillars. On one occ., an ad. appears at the entrance of the box with a white fecal sac and swallows it on the spot. During the whole observation period there are no vocal emissions.

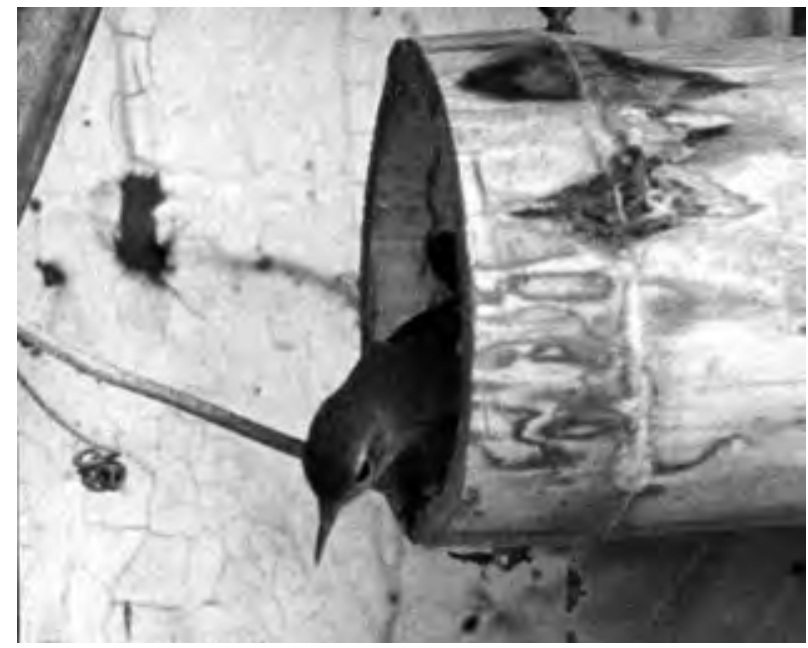

Figure 122. Troglodytes aedon: checking before leaving. 


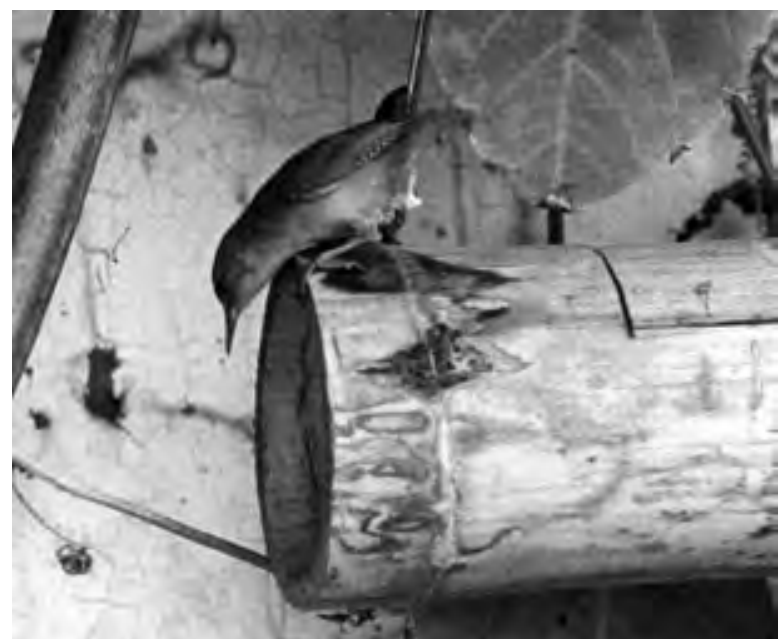

Figure 123. Troglodytes aedon: having a watchful eye on its dfpring.

19/12/1965. $6^{\text {th }}$ day: The young open their eyes for the first time. Head and back are covered with white, hairy down. Quills appear on the wings (Fig. 124).

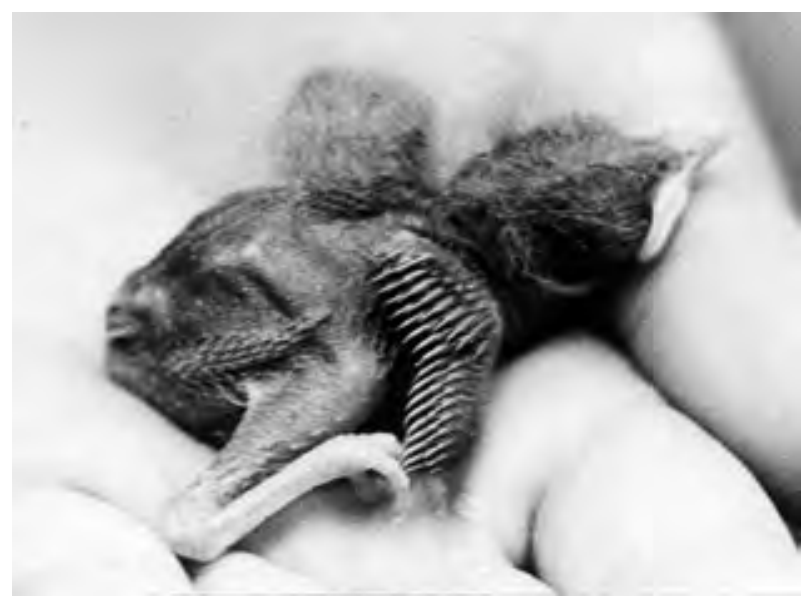

Figure 124. Troglodytes aedon: 6 days old.

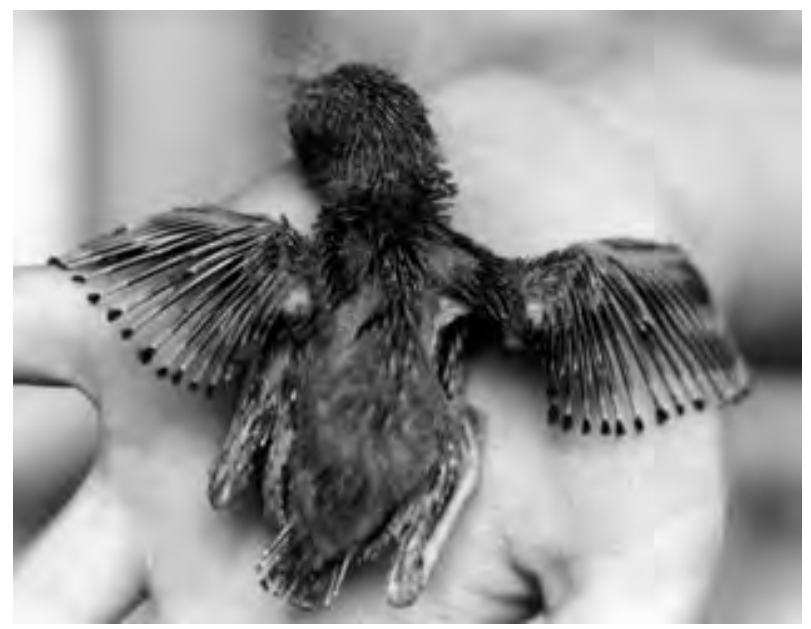

Figure 125. Troglodytes aedon: 10 days old.

20/12/1965. $7^{\text {th }}$ day (summary of protocol): $13: 55-14: 55$

7 feedings, or one every 8-9 min. The young are being guarded by one of the ad. in two seperate 'sessions' for a total of $19 \mathrm{~min}$. On three occ. the food is passed on to the 'sitting' partner. In general, the food portions are larger than five days earlier. On one occ., an ad. arrives with a caterpillar, that obviously is too big for the fledglings, so it is swallowed by the ad. itself. Twice an ad. leaves the box with a fecal sac.

21/12/1965. $8^{\text {th }}$ day: First vocal emissions.
22/12/1965. $9^{\text {th }}$ day: The fledglings open their eyes. The first redbrown feather-tufts appear on head, back and side. When I lift the lid of the box, the fledglings duck and remain motionless (the days before, they adopted a begging gesture with bills wide open).

23/12/1965. $10^{\text {th }}$ day: Feather-tufts appear at the wings (Fig. 125).

25/12/1965. $12^{\text {th }}$ day: The tail feathers begin to develop.

27/12/1965. $14^{\text {th }}$ day (summary of protocol): 09:30-10:30

8 feedings or one every 7-8 min. The ads. do not stay any longer within the box after the feedings - there is either no space or no need for it any more. The fledglings now tweet, whenever the ads. arrive, even before they touch the box. Twice the ads. appear without food, presumably just to check, if everything is o.k. (Fig. 123). On two occ., a fecal sac is disposed of. The ads. do not communicate nor does the male sing in the immediate neighbourhood of the nesting-site. The foodcarrying ad. approaches the box slipping cautiously through the foliage.

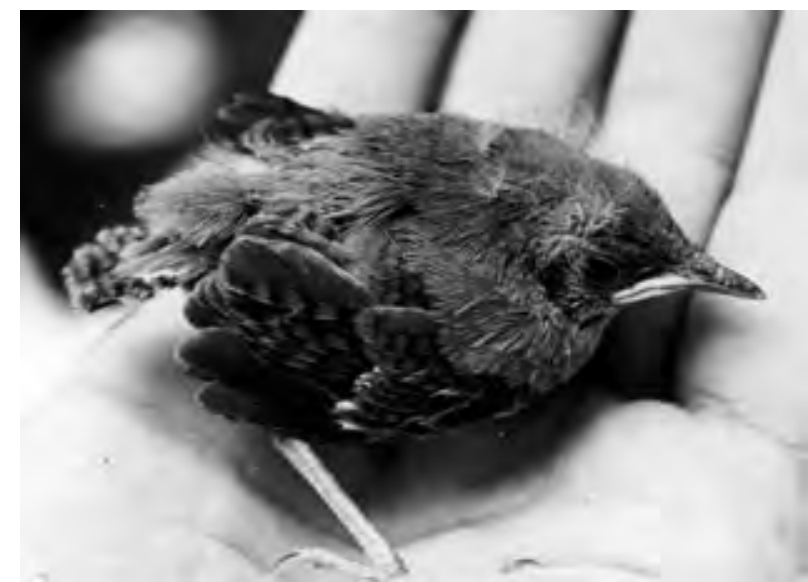

Figure 126. Troglodytes aedon: 18 days old.

31/12/1965. Last presence of the three fledglings.

01/01/1966. All three have left the nest. They seem to be hiding in the nearby uña de gato thicket. A food-carrying ad. appears now and then, and warning calls can be heard (observation descontinued).

Breeding period: 16-18 days

Feeding period: 21 days.

h) $16-20 / 10 / 1966$.

$16 / 10 / 1966$. Ad. with 4 young in the garden. Two of them follow it closely, begging defiantly. Another young is perched on a rose bush, the fourth is waiting on the ground. Apart from the begging call, they occ. emit the familiar rrebrreb. The ad. is completley absorbed by the feeding business, with no time left to care about the safety of its offspring. Maybe there is no need of this, because the young fly quite well allready. - Ads. and juvs. recorded in different parts of the garden until 20/10/1966.

\section{i) $28 / 01-02 / 02 / 1967$}

28/01/1967. Ad. is feeding a young Molothrus bonariensis in the garden. Its conspicuous and enduring begging call: tsyAp'tsy $A p$. Generally, the feedings take place in the interior of bushes or trees. They consist of larvae, moths and caterpillars. When a cat arrives at the scene, both ads. are highly alarmed, emitting both kinds of warning: pseepsee or rrebrreb. The Molothrus-young then curbs its begging call to a whispering tse'tse'tse. Last feeding 18:45.

$02 / 02 / 1967$. The young $M$. bonariensis is still being fed. Perched on the garden door or on top of a hedge it begs continuously. The food-carrying ad. tries to lure it regularly to a safe place as e.g. into the uña de gato thicket.

\section{k) $27 / 02-13 / 04 / 1967$.}

27/02/1967. First record of an ad. entering the new bamboo nesting box installed on the 10.01.67 (same place as $\rightarrow \mathrm{g}$ ). The randomly placed material consists of grass stems, grass roots, twigs, a dry leaf, 
spider web, cotton threads and a wool pad.

$09 / 03 / 1967$. Nest completed: the deep scrape is densely lined with feathers and hair (horse and human).

11-13/03/1967. Three eggs deposited at 24 hour intervals before 7 am (last control the evening before).

27/03/1967. Two young hatched: $1^{\text {st }}$ before $7.30 \mathrm{am}, 2^{\text {nd }}$ between $7.30 \mathrm{am}$ and $0.30 \mathrm{pm}$.

\section{8/03/1967. $3^{\text {rd }}$ young hatched before $7.30 \mathrm{am}$.}

13/04/1967. All three leave the nest. - The ads. remained silent through most of the reproduction period. Shortly afterwards, the male begins to sing again.

Breeding period: $15-17$ days

Feeding period: $17-18$ days

l) $12-27 / 08 / 1967$.

$12-13 / 08 / 1967$. Three eggs deposited in the garden door $(\rightarrow$ $\mathrm{c}, \mathrm{d}, \mathrm{f})$.This time, T. aedon 'accepts' that the door is open during the day and closed at night. Male sings regularily, even on top of the door. $\mathrm{He}$ starts at $6.30 \mathrm{am}$ despite the damp and foggy weather.

27/08/1967. All three fledgelings hatched.

Breeding period: $15-16$ days

m) Mid December 1968. Brood in the hollow top of a street lamp. Several feedings recorded.

n) $24 / 02-02 / 03 / 1969$.

24-26/03/1969. Nest with young on the flat roof of a two-story house beneath a water tank. The male is busy marking and defending his territory. Within a limited range he often changes his song perch. About $100 \mathrm{~m}$ away there is another singing male. Feeding the young is the main task of the female. She accounts probably for 3 out of 4 feedings. Judging from the size of the prey - e.g. a cricket or a $2-3 \mathrm{~cm}$ long caterpillar - the fledglings must be quite developed. Several times a fecal sac is disposed of.

$02 / 03 / 1969$. Male singing on the edge of the roof at sunset $(6.30$ $\mathrm{pm})$. Meanwhile the female is searching for food in the adjacent cotton field. Suddenly, she is surrounded by $\mathbf{3}$ young. She leads them immediately out of sight. - Later: the female interrupts her food-hunting job and takes a dust bath. The hollows are probably the work of Passer domesticus. She obviously takes delight in nuzzling into the hollow, wings and tale spread out. Occ., she submerges her face sidewise into the powder-like dust.

o) $25 / 02 / 2003$. Fully fledged young on the lawn in a patio bordered with bushes and climbers, begging metronome-like psepsepse. Both parents take part in the feeding. All of a sudden, a pair of Pyrocephalus rubinus lunges at the young. The clash, accompanied by a vehement clamor, lasts only a few seconds. Before an ad. T. aedon can intervene, the intruders retreat and eventually disappear into their own territory in the neighbouring garden.

Breeding statistics (La Victoria, Miraflores):

Number of eggs: $3(5 \mathrm{x}), 4(2 \mathrm{x})$

Breeding period: $15-18$ days

Feeding at nest: $15-21$ days

Breeding records outside La Victoria and Miraflores

16/06/1963. Above San Bartolomé, Rímac Valley, Lima, 2000 m: Ad. feeding young in a narrow quebrada with riparian vegetation.

02/05/1964. Canta Valley, Lima, 3400 m: Food-carrying ind. in montane scrub.

07/05/1964. Monterrico/Lima: Nest with young in a horizontal bamboo stake, that is part of a roof construction. Both ads. participate in the feeding. On one occ., the male sings nearby - his bill jammed with food.
06/02/1966. Urbanización California, Chosica, Rímac Valley, Lima, $800 \mathrm{~m}$ : Nest with young in segment of bamboo similar to the precedent record, except that the entrance is on the side and not at the end of the stake. Both parents feed. Occ., the male sings on top of the garden wall immediately after feeding.

28/07/1967. Cajatambo, Pativilca Valley, Lima, 3400 m: Ind. extracts black insect or spider out of a crevice in "adobe" wall and disappears with it beneath the roof.

24/08/1969. Lomas de Lachay, $70 \mathrm{~km}$ north of Lima, $400 \mathrm{~m}$ : Ad. with 2 young in the rocky part with scattered trees.

End of February 1970. Urbanización California: Ad. feeding young.

04/07/1972. San Ramón, Chanchamayo Valley, Junín, 800 m: Brood in the interior of an abandoned chapel inside a broken candle holder (Fig. 127). The female is breeding, while the male is singing vigorously, perched in an open window. Three eggs: $19 \times 15 / 18.5 \times 14.5 /$ ? $\mathrm{mm}$.

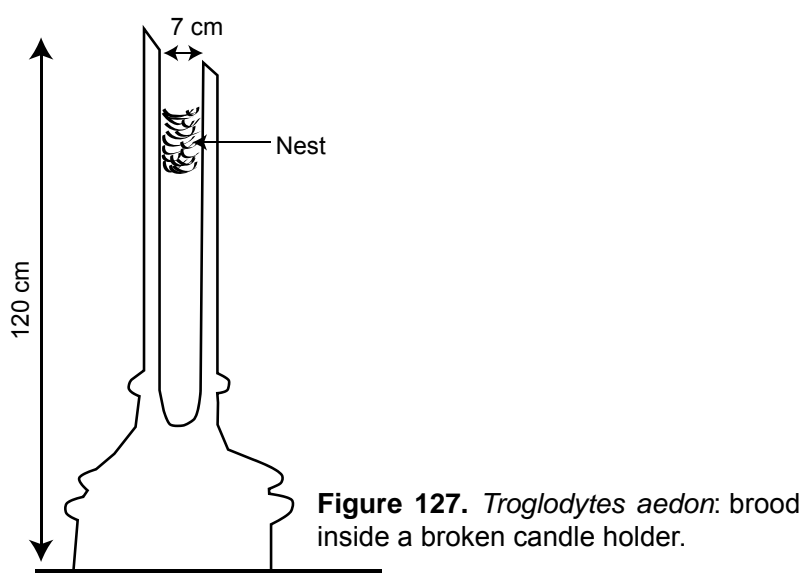

\section{Campylorhynchus fasciatus}

Sightings.- Max. alt. on west slope, acording to BP $1500 \mathrm{~m}$. Sightings above $1500 \mathrm{~m}$ : Chicama Valley, La Libertad, 1500-2000 m; Contumazá, Cajamarca, 2700 m; Yumagual, Jequetepeque Valley, Cajamarca $2800 \mathrm{~m}$.

26/09/1971. Sechín near Casma, Ancash: Pair on Prosopis, most of the time foraging quietly. Suddenly one of them starts screaming, immediately followed by its partner. For a short time, both engage in a raspy duet, then fall silent as abruptly as they had begun.

21/02/2003. Bosque de Poma, Batán Grande, Lambayeque: Common; ind carrying nesting material to a seemingly complete nest with lateral entrance, situated in the outer branches of a Prosopis.

\section{Polioptilidae}

\section{Polioptila plumbea}

Sightings.- Coast from Tumbes to La Libertad, also Marañón Valley (Chagual, $1250 \mathrm{~m}$ ); Lima.

15 - 16/02/1964. Near Hacienda Mallares, Sullana, 300 m, Piura: Quite common in scrub at the edge of cultivated land; also in the Amotape Mountains, 600-800 m, in deciduous forest.

End of January 1966. Between Puente Trapiche (Canta Valley) and Quilca (Chancay Valley), Lima, $1000 \mathrm{~m}$ : Two ind. in dry montane scrub with cacti.

19/08/1967. Quebrada Tinajas, Lurin Valley, 2200 m: Southernmost and highest record on west slope; pair in dense montane scrub.

\section{CINCLIDAE}

\section{Cinclus leucocephalus}

Sightings.- Between 1800 and $3500 \mathrm{~m}$

NP: La Libertad, Marañón Valley

CP: west slope: Lima: Rio Huaura, Chancay, Chillón, Rímac, Santa 
Eulalia, Lurin, Cañete; east slope: Pasco, Rio Paucartambo; Junín, Rio Mantaro

\section{South Peru: Cusco, Rio Urubamba}

19/09/1968. Rio Paucartambo, Pasco, 2000 m: Probably courting behavior: An ind. chases another in flight. The pursuer then poses on a flat stone in midstream. He patters about, holding his head and bill straight upwards. The other ind., only an arm length away, remains passive.

\section{TURDIDAE}

\section{Catharus fuscater}

03 - 04/03/1972. San Andrés de Cutervo, Cajamarca, 2400 m: Two sightings on the edge of the National Park. Ind. carrying moss to a nesting site situated in a patch of bushes surrounded by pasture land.

10/07/1993. Pataz, Marañón Valley, La Libertad 2300-2800: Quite numerous in some quebradas with rich vegetation.

\section{Turdus chiguanco}

Breeding records

02/02/1965. Casta, Santa Eulalia Valley, Lima, 3100 m: Foodcarrying ind.; nest probably in a low scrub outside village.

12/03/ 1966. Quebrada Huancapuna, Rímac Valley, Lima, 2300 m: Food-carrying ind. perching in an inaccessible rock face.

25/03/1966. Chumcha, Santa Eulalia Valley, Lima, 3000-4000 m: In two occ., food-carrying ind. in montane scrub.

23/02/1967. Arequipa, $2400 \mathrm{~m}$ : Ind. in a park, jamming its bill with worms, then departing to the nesting site on a high Eucalyptus tree.

28/04/1967. Opica, Santa Eulalia Valley, Lima, 2400 m: Foodcarrying ind.

20/01/1972. Muńani, Puno, 3900 m: Nest in an unpenetrable cypress; twice food-carrying ind.

31/01/1972. Torata, Moquegua, $2200 \mathrm{~m}$ : Nest with young on a Salix on river bank, 3-4 m above the water. Both ads. take part in the feeding.

\section{Turdus serranus}

04/03/1972. San Andrés de Cutervo, Cajamarca, 2400 m: Group of about 10 ind. in a forest relic, foraging on a tree with cherry-like fruit. They begin at the top, gliding down by and by, feeding eagerly on the plentiful fruit. Occ., they move on to the next tree.

\section{MimidaE}

\section{Mimus longicaudatus}

Sightings.- Coast from Tumbes to Ica. Max. alt. in the coastal valleys of Lima: Canta 2100 m, Rímac 2200 m, Lurin/Quebrada Tinajas $2800 \mathbf{~ m}$. No sightings in the urban area of Lima until 1999.

Behavior/Voice.- Mostly in small groups of up to 10 inds., gathering conspicuously on bushes, trees (Fig. 128) or telephone wires. $-M$.

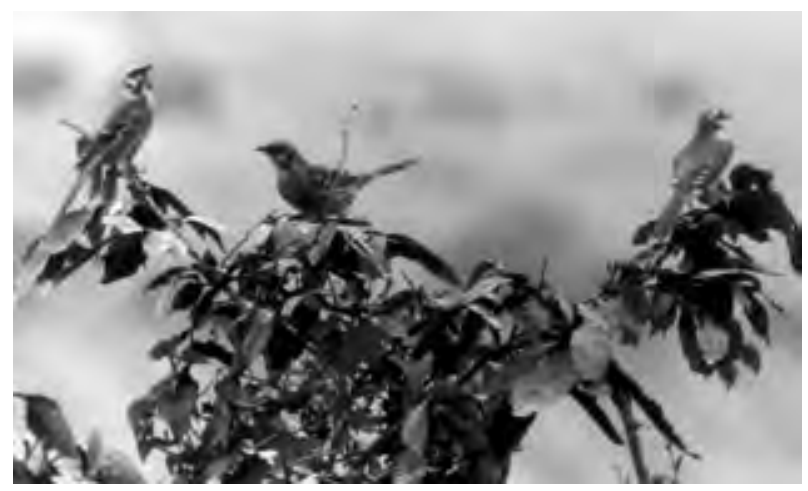

Figure 128. Mimus longicaudatus.
Longicaudatus is the most talented singer on the coast. The melodious and varied song is often given in groups. A stanza lasts 2-5 min, interrupted only by short intervals. The song can be heard at any time of the day. M. Longicaudatus sings regularly at mid day, even on hot days, when other species fall silent. Rainfall seems to stimulate song activity.

28/10/1963. Santa Eulalia Valley, Lima, 1800 m: Numerous; feeding on the berries of Schinus molle. Together with Crotophaga sulcirostris on a flooded pasture with plenty of prey.

30/08/1968. Mala Valley, Lima, $100 \mathrm{~m}$ : Perched in small groups on bushes along newly plowed field. Some hopping on the ground, in search of food.

07/11/1968. Mouth of Rio Mala, Lima: The whole day long vivid song activity. - Pair engaged in nest-building. In a perimeter of 50-100 $\mathrm{m}$ they gather dry twigs and branches, some exceed the length of the birds. In $8 \mathrm{~min}$. they execute 6 flights. The nest is located in a bush thicket 3-4 $\mathrm{m}$ above the ground.

12/03/1972. Urbanización California, Chosica, Lima, 800 m: Foodcarrying ind. approaching a high cypress; another one is feeding on figs.

15/09/1973. Mouth of Rio Mala, Lima: Very numerous. Three ind. perched on a branch of a tree: Young between two ad. flapping its wings and begging loudly.

25/12/1972. Urbanización California: Ind. with nesting material (branch).

17-21/02/1999. Samaca, Ica Valley, Ica, 200 m: Common. - Foodcarrying ind. warning persistently. It finally swallows the prey itself, in order not to reveal the nesting site, which probably lays in an extensive Prosopis thicket.

\section{MOtACILLIDAE}

\section{Anthus lutescens}

Sightings/Habitat.- Coast of Lambayeque (1x), La Libertad (1x), Lima (23x) Gramadales near river mouths and lagoons; lomas, cultivated fields.

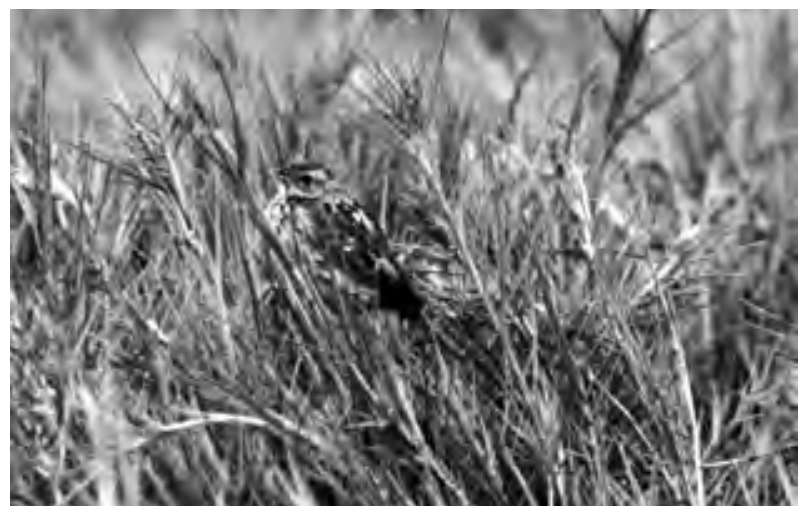

Figure 129. Anthus lutescens.

Song.- consists of two parts: an ascending tsir'tsir'tsir and an even slreee... In relation to the display flight part one corresponds to the rising phase and part two to the gliding phase. Part one may also be emitted between dislpay flights on the ground. Song (without display flight) consists of two or three repetitions followed by a pause.

Song activities in different habitats:

Lomas (Lachay, Pacta): (June) Aug-Oct

Gramadales (Villa, Chilca, Puerto Viejo, mouth of Rio Virú): Sep-Feb.

Cultivated fields (Miraflores/Lima): Nov-Feb.

December 1967 - March 1968. Outskirts of Miraflores/Lima: 2-3 pairs present on a cotton field, measuring about $100 \times 200 \mathrm{~m}$. The field was cleared of weed in mid Jan, when plants were about $30 \mathrm{~cm}$ tall. As a consecuence, a possible brood would have been destroyed. Nonetheless, the song activity goes on until the end of Feb; presence recorded until mid Mar. 


\section{THRAUPIDAE}

\section{Schistochlamys melanopis}

05/07/1972. San Ramón, Chanchamayo Valley, Junín, 800 m: Ind. in second growth.

\section{Cissopis leveriana}

Max. alt.: $\mathbf{1 8 0 0} \mathbf{m}$ between Abra Tapuna and San Francisco (Rio Apurímac), Ayacucho.

\section{Hemispingus melanotis}

31/07/1976. Baños Yumagual, Jequetepeque Valley, Cajamarca, $2800 \mathrm{~m}$ : Fairly common in humid montane forest. Two or three ind. together; very lively. On one occ. feeding on a tall, dry Salvia.

\section{Thlypopsis ornata}

Sightings/Habitat.- Between 2600 and $3000 \mathrm{~m}$ from relative dry montane scrub with Escallonia to humid montane forest.

West slope: Baños Yumagual, Jequetepeque Valley, Cajamarca; Monterrey, Callejón de Huaylas, Ancash; Chiuchín, Huaura Valley, Lima; Zárate, Rímac Valley, Lima.

East slope: Rio Paucartambo, Pasco.

Behavior.- Hopping and slipping incessantly through branches and foliage of bushes or trees in search of insects.

\section{Ramphocelus nigrogularis}

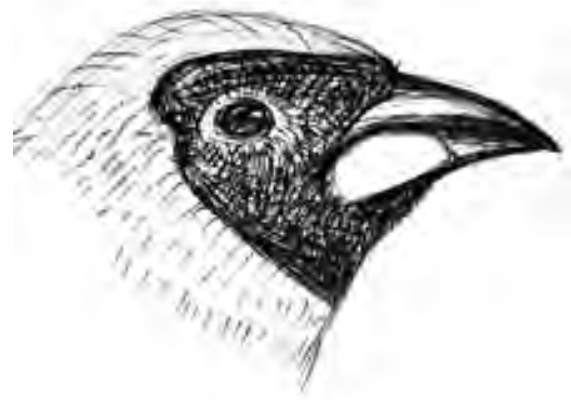

Figure 130. Male of Ramphocelus nigrogularis.

13 - 20/01/1970. Panguana Research Station, Rio Llullapichis, Huánuco, $300 \mathrm{~m}$ : Common in second growth and at river edge. - Rivalry of two males: They attack each other in the air, swirling around. After landing on a scrub, one of them submits himself by hanging upside down from a branch. The other takes a dominant position right above his rival. Both remain in unchanged position for at least one minute. When the defeated male finally escapes, the winner tries to peck him.

Nest in a grass and bush thicket, about 1,60 m high (Fig. 131); simple, thin-walled, oval cup. Inner diam. $5,5 / 8,5 \mathrm{~cm}$, depth $5 \mathrm{~cm}$.

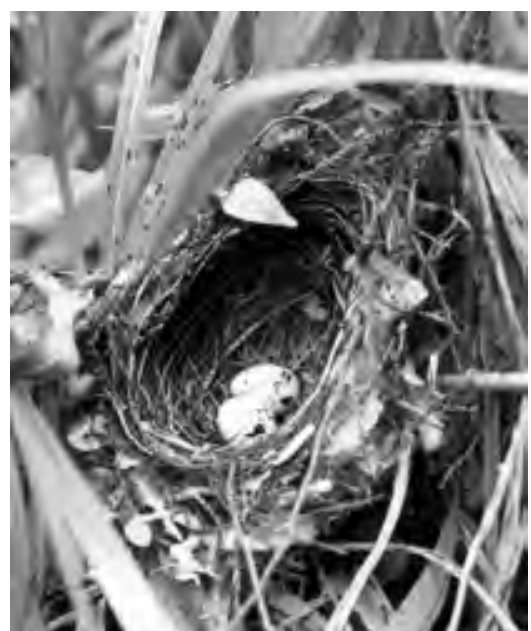

Figure 131. Ramphocelus nigrogularis: nest with clutch.
It is suspended from different stems and is interwoven with leaves of tall grass. On the outside it is draped with withered leaves, the inside is lined with stems and other vegetal fibers. Both eggs measure $16 \times 21$ $\mathrm{mm}$. Colour: Light-turquoise with a ring of black splatters around the broad pole.

\section{Thraupis bonariensis}

Sightings.- Mainly on west slope of Central Peru between 1500 and $3000 \mathrm{~m}$. Max. alt. $3800 \mathrm{~m}$, Huaura and Chancay Valleys, Lima; min. alt. 800 m Rímac Valley, Lima.

31/08/1963. Santa Eulalia Valley, Lima, 1600 m: Group of males and females of at least five inds. in river edge thicket on a Schinus tree, feeding on berries. To reach the food, they move about skillfully in the thin, hanging branches.

23/01/1967. Monterrey, Callejón de Huaylas, Ancash, 3000 m: Several inds. in cultivated area, some feeding fruits of Prunus serotina. Song: TSEE'tsew. - Male gathering nesting material. It rips off a dry stem of grass, then picks up a small twig and carries both to a nearby P. serotina tree.

Nest with eggs on a Thuja tree in hotel garden, about 3,5 m high, close to the trunk (Fig. 132). Outside: Strong, bulky construction made of dry twigs. Inside: Deep scrape lined with soft grass stems. Outer diam. about $18 \mathrm{~cm}$, inner diam. about $8 \mathrm{~cm}$. Three elongated eggs; lightgreen, densely strewn with light and darkbrown splatters and conspicuous sepia-brown streaks. Specimen: $18 \times 28 \mathrm{~mm}$. I observed the female breeding on three occasions; the male showed up twice.

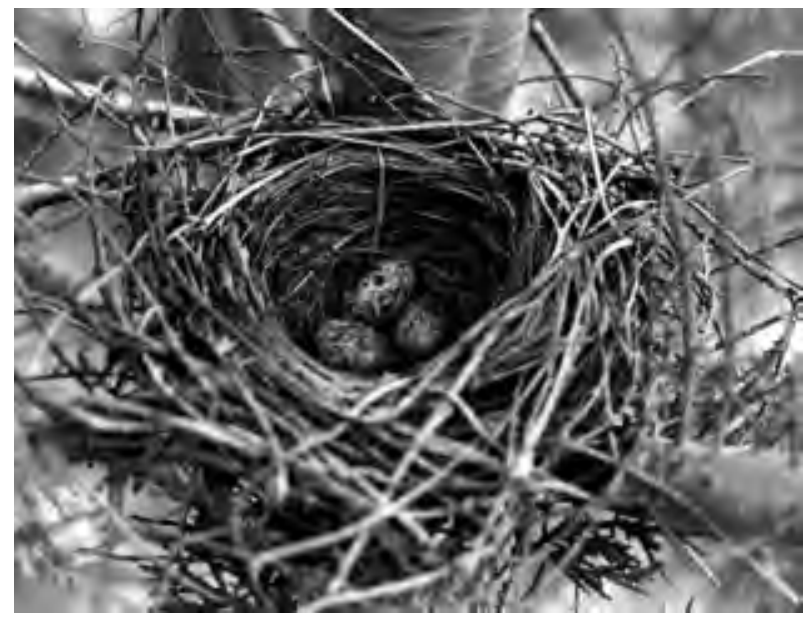

Figure 132. Thraupis bonariensis: nest with clutch.

06-12/06/1967. Chiuchín, Huaura Valley, 2600 m, Lima: Common in the cultivated areas, as well as in the adjacent semi-arid montane scrub. Female on a peach tree in an abandoned orchard, snatching a small piece of an unripe fruit. She carries it to a young on a nearby orange tree, which begs incessantly tsee'tsee'tsee... $3400 \mathrm{~m}$ : Male perches on a scrub, feeding young. During the following song, he rises his head up to a near vertical position. - Considerable number of fledglings recorded in the same area.

10/07/1988. Paucartambo, Cusco, 3000 m: Male in an Eucalyptus grove on a $50 \mathrm{~cm}$ high Solanacea with violet-blue blossoms and orange fruits, tearing off small pieces of leaves (Fig. 133). It chews them before

Thrapois bonarionsis leeds on leaves of Solanaceae

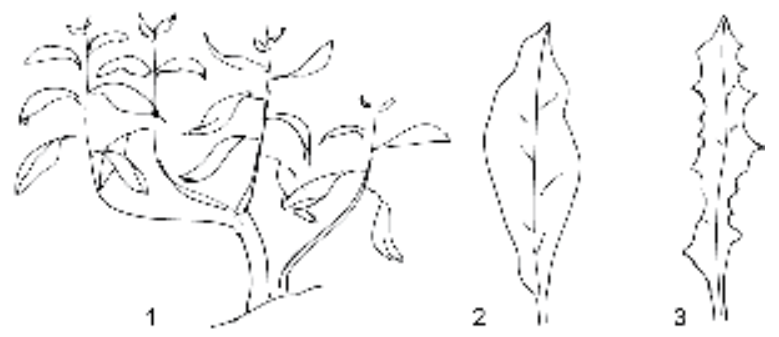

Figure 133. 1: whole plant 2 : intact leaf 3 : nibbled leaf. 
swallowing. On one specific plant, nearly all leaves have been nibbled. (When crumbled, the leaves emit a pungent smell.)

\section{Anisognathus lacrymosus}

08/01/1965. Near Chachapoyas, Amazonas: Fairly common in humid montane forest between 2500 and $3000 \mathrm{~m}$; foraging in trees.

02/03/1972. San Andrés de Cutervo, Cajamarca, 2400 m: Ind. at the edge of humid montane forest, feeding on white berries on a tree.

\section{Tangara viridicollis}

28/02/1972. San Andrés de Cutervo, Cajamarca, 2400 m: Pair on Cecropia in pasture land with relics of humid montane forest, pecking away avidly at the club-shaped Cecropia fruits.

\section{Tangara cyanicollis}

05/08/1963. Between Abra Tapuna and San Francisco (Rio Apurímac), Ayacucho, $1300 \mathrm{~m}$ : Ind. in orchard.

05/02/1999. Near Moyobamba, San Martin, 850 m: Several sightings in second growth.

\section{Tangara vassori}

28/02/1972. Between Sócota and San Andrés de Cutervo, Cajamarca, $2600 \mathrm{~m}$ : Pair in thicket of humid montane forest (relic).

02/03/1972. San Andrés de Cutervo, 2400 m: Ind. on a tree at the edge of humid montane forest, feeding on small berries (or buds).

\section{Conirostrum cinereum}

Behavior.- Moves restlessly about in blossoming trees, bushes and ornamental plants, emitting a constant whisper. Often in pairs or small groups. Picks and gleans insects from top and underside of leaves. Examines blossoms in search of prey and nectar.

Voice/Reproduction.- Song activity starts in Miraflores/Lima at the end of Aug, getting more intense through Sep/Oct, reaching its height in Nov and declining in Dec. The first clutch coincides with the blooming of trees and bushes in gardens and parks. Courting activity reaches another, though minor height in Feb (second clutch?). Song is a simple twitter. The sequence of 4-6 notes is repeated several times.

16/12/1963. Miraflores, Lima: Full-fledged young in school yard.

16/02/1964. Sauce Grande, Amotape Mountains, Piura, 600-900 $\mathrm{m}$ : Common in deciduous forest.

26-29/02/1964. Mala Valley, Lima, 700-1700 m: Recorded regularly in riparian vegetation and all kind of shrubbery. An incessant tsee'tsee reveals its presence.

27-29/11/1964. Huaura Valley, Lima, 3800 m: Sporadic in light Polylepis wood and scrub, especially Ribes.

07-14/02/1966. Huariaca, Pasco, 3000-3300 m: Regularly in montane scrub with Agavae and Eucalyptus.

30/07 - 04/08/1966. Hacienda Cochabambe, Rio Chusgón, La Libertad, 2400 m: Common; especially on blooming Gravilea. Also in vegetable garden, where it picks insects from the underside of leaves. It even manages to cling to the plain heads of cabbage.

23-31/08/1968. Miraflores/Lima: Ind. sings daily in the garden at the same time $(7 \mathrm{pm})$ on the same tree.

24/02/1969. Miraflores/Lima: Singing ind. in a cotton field. It often changes its perch, flying from one cotton shrub to another, at a distance of 5-10 m.

\section{Oreomanes fraseri}

Sightings/Habitat.- In Ploylepis wood between 3700 and $4200 \mathrm{~m}$ in Lima (Huaura Valley, Santa Eulalia Valley) and Ayacucho (slope of Nevado Sarasara).

Behavior.- Oreomanes fraseri produces a rustling noise when examining the paper-thin layers of Polylepis bark, which can be heard at quite a distance.
24-25/04/1971. Chumcha, Santa Eulalia Valley, Lima, 3900-4100 m: Fairly common in extended Polylepis forest. It starts singing at $5.45 \mathrm{am}$ on a cold, foggy morning. Song: an excited, two pitched chatter or twitter.

\section{Xenodacnis parina}

27-29/11/1964. Huaura Valley, Lima, 3800 m: Characteristic bird in light Polylepis wood. Vigorous and varied song; call: wut'wut... or wet'wet.

01/11/1965 - 26/03/1966 - 04/12/1966 - 26/04/1969 24/04/1971. Chumcha, Santa Eulalia Valley, Lima, 3900-4100 m: Sporadic in Polylepis wood, preferably on Gynoxys, where it gleans insects from the underside of the leaves. Single males, pairs or mixed groups.

16/06/1968. Between Mollebamba and Orongoy, Pampas Canyon, Ayacucho, $3500 \mathrm{~m}$ : Male on Gynoxys in dense montane scrub with trees.

\section{Diglossa sittoides}

\section{Sightings}

NP: Cajamarca, Contumazá, 2700 m.

CP: Lima between 3000 and 3500 m: Huaura, Canta and Santa Eulalia Valleys.

\section{Diglossa brunneiventris}

\section{Sightings}

NP: Cajamarca $3400 \mathrm{~m}$.

CP: west slope between 3000 and 4200 m: Ancash: Pativilca Valley; Lima: Rímac Valley and Santa Eulalia Valley; east slope between 2600 and $3300 \mathrm{~m}$ : Ancash: Callejón de Conchucos; Pasco: Paucartambo Valley.

SP: Arequipa: Cotahuasi Valley, 3400 m; Cusco: Paucartambo Valley, 3000-3500 m; Puno: Isla Taquile, $3800 \mathrm{~m}$.

Behavior.- Diglossa brunneiventris is a true 'flower-piercer': It forages predominantly on flowering bushes and trees. To reach exposed flowers, it performs acrobatic acts.

25/04/1969. Chumcha, Santa Eulalia Valley, 4000 m: Ind. on a climber with trumpet-shaped, salmon coloured flowers in Polyleps wood. Clinging to the stem of the flower, it introduces its bill into the calyx to reach nectar and/or insects.

17-19/09/1968. Rio Paucartambo, Pasco, 2600 m: Quite numerous in bush forest. It shows a predilection for a red-violet Leguminosae. Song activity begins at $5.30 \mathrm{am}$ and lasts until dusk. Song: an inarticulate, hasty trill, emitted from half hidden perches, lasting a few sec.

\section{INCERTAE SEDIS}

\section{Coereba flaveola}

11/01/1964. Near Batán Grande, Lambayeque: Ind. in Prosopis wood, picking a piece of cotton out of a decaying nest, presumably to use it for a new one.

02/07/1972. San Ramón. Chanchamayo Valley, Junín, 800 m: Ad. foraging in red blossoms of an oropel tree, followed everywhere by a begging and chirping young.

28/01/1973. Yarinacocha/Pucallpa, Loreto, 200 m: Ind. with nesting material (vegetal fiber) in second growth.

\section{Tiaris obscurus}

12/07/1993. Chagual, Rio Marañón, La Libertad, 1250 m: Common in dry scrub, orchards and riparian vegetation. Often in small flocks. Song a repetitious twitter.

20/02/1999. Samaca, Ica Valley, Ica, $200 \mathrm{~m}$ : Ind. in riparian vegetation, singing on top of a Tessaria.

\section{Saltator aurantiirostris}

\section{Sightings}

NP: west slope: Cajamarca 2700/2800 m; La Libertad 1500 m; east slope: Cajamarca 2100-2600 m; La Libertad 2600-3000 m. 
CP: west slope: Ancash 3100/3700 m; Lima 2800-4200 m; Huancavelica 2800/3000 m; east slope: Ancash 3100/3200 m; Huánuco 3100 m; Pasco 2600-3300 m.

SP: west slope: Arequipa $3400 \mathrm{~m}$; east slope: Ayacucho $3400 \mathrm{~m}$; Apurímac $3200 \mathrm{~m}$; Cusco 2500-3500 m.

Min. alt: Coina, Chicama Valley, La Libertad, 1500 m (BP 2100 m).

Max. alt.: Chumcha, Santa Eulalia Valley, Lima, 4200 m (BP $4000 \mathrm{~m})$.

Habitat.- Contrary to the statement of BP "not found in more humid habitats", I recorded S. aurantiirostris in humid montane forest (Zárate, Lima; Yumagual, Cajamarca)), in Alnus dominated river edge vegetation (Contumazá, Cajamarca) and in Polylepis woods (Yanganuco, Ancash; Huaur Valley and Santa Eulalia Valley, Lima).

Voice.- Song: A vigorous, melodic sequence of varying notes with different lengths, often emitted from conspicuous perches as rocks, hedgerows, scrub, Opuntia, lower branches of Eucalyptus. The song activity begins in Feb and lasts until Sep (no records for June).

18/11/1972. Chancay Valley, Lima, 3800 m: Pair in mountain scrub (with Ribes) feeding on fruit of a climber with salmon coloured flower.

\section{Saltator striatipectus}

\section{Sightings}

NP: west slope: Piura 200 m; east slope: Cajamarca 1600/1800 m

CP: west slope: Ancash 100 m, Lima 0-800 m, Ica 200 m; east slope: La Libertad $1200 \mathrm{~m}$

15/02/1964. Hacienda San Jacinto, Piura, 200 m: Nest with young on a Citrus tree about $3 \mathrm{~m}$ high, placed in the fork of a branch. A nearly grown-up fledgeling is sitting on the rim of the nest. Both ads. are around.

06/03/1972. Cochabamba, Rio Chotano, Cajamarca, $1600 \mathrm{~m}$ : Common in cultivated area with hedgerows. Ind. singing on top of a bamboo.

July 1983. Urbanización California, Chosica, Rímac Valley, Lima, $800 \mathrm{~m}$ : Daily song in the garden. Calls: tsic and - very characteristic - tsigraa... Male sitting on a window sill repeatedly attacks his mirror image - a supposed rival - in a window pane, interrupted occ. by short song outbursts. The attacks may last as long as a quarter of an hour.

08-09/07/1993. Chagual, Rio Marañón, La Libertad, 1200 m: Common in orchards and scrub. Several inds. singing simultaneously in the morning. Complete song consists of four notes; a low pitched note alternates with a high pitched one: trew'ts YEw'dew'ts Y'dew, the last two notes occ. missing; also emitting a quiet trill, like tse'trrr...'tse'tse.

19/02/1999. Samaca, Ica valley, $200 \mathrm{~m}$ : Ind singing in the morning on a Tessaria.

\section{EMBERIZIDAE}

\section{Zonotrichia capensis}

Sightings.- Coast and Andes; most frequent on the coastal plains and between 2300 and $3800 \mathrm{~m}$; only three records between 500 and $1500 \mathrm{~m}$; also on the east slope.

Preproductive periods of Zonotrichia capensis

\begin{tabular}{|c|c|c|c|c|c|c|c|c|c|c|c|c|}
\hline & 1 & 2 & 3 & 4 & 5 & 6 & 7 & 8 & 9 & 10 & 11 & 12 \\
\hline C & -- & - - - & - - & & & & - & $\ldots$ & & $\cdots$ & $\ldots$ & \\
\hline $\mathrm{n}$ & & & & & & & & & & & 1 & \\
\hline b & & & 1 & & & & & & & $\|$ & & - \\
\hline $\mathrm{fn}$ & & & & & & & & $\|$ & & & & \\
\hline fo & & & | & & & & & & & $\|$ & & 1 \\
\hline
\end{tabular}

Figure 134. 1 - 12: month/year; c: courting activity (song); n: nestbuilding; b: breeding; fn: feeding at nest; fo: feeding outside nest; | single record; --- observation period.
The diagram refers to the coastal area of Lima. It shows, that the courting activity starts in June, reaches its height in Sep and continues until Feb. The 'proper' reproduction period begins in Aug and lasts until March (April).

Habitat.- Coast: lomas, fields, gardens and parks. Andes: montane scrub, riparian vegetation, fields, orchards, villages, humid montane forest, Polylepis wood; on the east slope $Z$. Capensis is common in secondary growth and cultivated areas.

Voice.- The vocal emissions vary individually and geographically. The song consists mostly of three to four parts: A low, one- or two-note introduction (tsew or tew), a vigorous, sustained central part (tswYew), followed by some declining, accelerated and repetitive notes, ending - in certain regions - by a trill. The song is often incomplete, occ. reduced to the central part. Some inds. have two or three song variations, repeating each of them several times. $Z$. capensis can be heard from dawn to dusk, but is most active early in the morning and late in the afternoon. In the cities - stimulated by the artificial illumination - it is not uncommon to hear it at night $(\rightarrow 09.03 .66+25.03 .66)$; sings also during rainfall. Occ. several males engage in a kind of song contest.

28/10/1963. Miraflores, Lima: Brood in a hedge of pomegranates bordering a schoolyard, about $1.70 \mathrm{~m}$ above the ground. The hemispherical nest is thick-walled and strongly built. Outer diam.14-18 $\mathrm{cm}$, inner diam. $5,5 \mathrm{~cm}$, height $9-10 \mathrm{~cm}$, depth $4,5 \mathrm{~cm}$. It consists predominantly of grass stems. The outside is camouflaged by dry leaves and a few pieces of paper. The interior features a dense layer of human hair. The four light blue-green eggs with brownish speckles differ slightly in colour and size: $24.5 \times 19 / 20.2 \times 18 / 21 \times 17.5 /$ ? $\mathrm{mm}$. Shortly after the 28 Oct, the brood was abandoned.

08/01/1964. Near mouth of Rio Reque, Lambayeque: Common in riparian vegetation. Nest in a patch of reed, made of grass-stems, about $30 \mathrm{~cm}$ above the ground (Fig. 135). Egg: whitish with irregularly strewn brown and lilac dots.

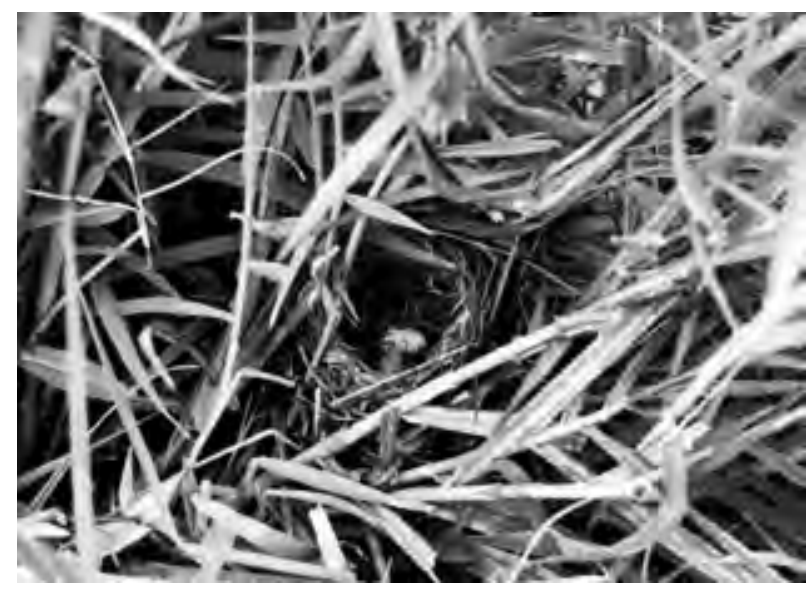

Figure 135. Zonotrichia capensis: nest with clutch.

07/03/1964. Miraflores, Lima: Young Molothrus bonariensis pursues its 'stepmother', begging uninterruptedly.

11/09/1965. Lomas de Lachay, $70 \mathrm{~km}$ north of Lima, $400 \mathrm{~m}$ : Intense courting activity on a foggy day. Males in aggresive mood, spreading occ. their tailes.

09/03/1966. Parque Central, Miraflores/Lima: Singing at night in mighty Ficus trees, illuminated by floodlight.

Mid of March 66 Miraflores, Lima: Nest (A) with 3 eggs, reportedly found in bamboo (Fig. 136). Comparison with another nest (B) of unknown origin:

$\begin{array}{lll} & \text { Nest } A & \text { Nest B } \\ \text { Outer diam. } & 10-12 \mathrm{~cm} & 11-12 \mathrm{~cm} \\ \text { Inner diam. } & 5 \mathrm{~cm} & 5,5 \mathrm{~cm} \\ \text { Height } & 6,5 \mathrm{~cm} & 7 \mathrm{~cm} \\ \text { Depth } & 4 \mathrm{~cm} & 4,5 \mathrm{~cm}\end{array}$




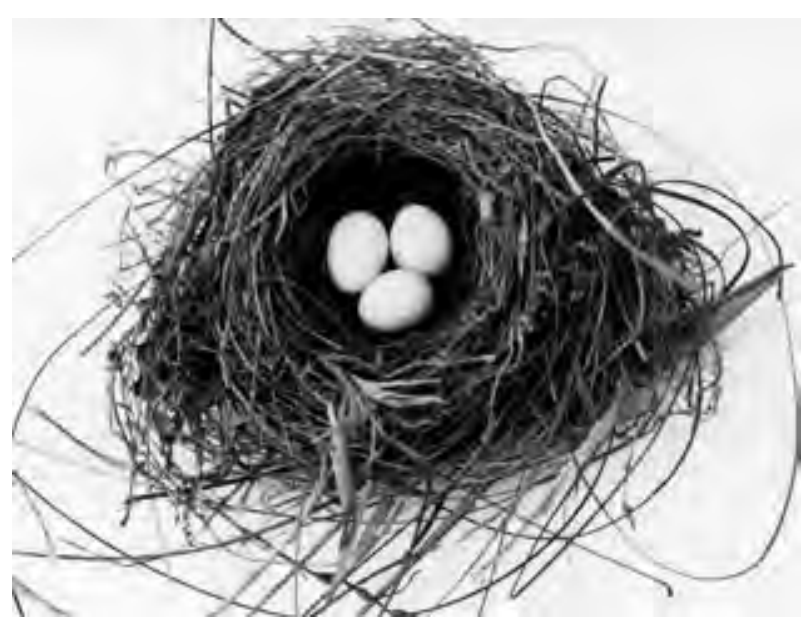

Figure 136. Zonotrichia capensis: nest with clutch.

Material: The interior of both nests is lined with hair (mostly human), the walls consist of grass stems and grass roots. B features some small leaves. Both nests are built upon a base of lose material: A features several leaf veins of Parkinsonia (up to $47 \mathrm{~cm}$ long), small leaves and grass roots. The base of $\mathrm{B}$ consists of grass stems and rhizomes, leaves (up to $13 \mathrm{~cm}$ long), some pieces of paper and dry blossom.

Eggs of nest A differ in form, color and size:

I. longish, light blue-grey with a few fine dark brown spots; $26 \times 18,5 \mathrm{~mm}$.

II. roundish, light grey-beige with brown and beige spots; $23,5 \times 19$ $\mathrm{mm}$.

III. roundish, light blue-grey with brown and beige spots, condensed around broad pole; $23 \times 18 \mathrm{~mm}$.

25-27/03/1966. Chumcha, Santa Eulalia Valley, Lima, 3300-3900 $\mathrm{m}$ : Common in montane scrub, also in Polylepis wood; intense song activity; several times at night in complete darkness.

03/12/1966. Same place: Faint song activity.

03-ca.13/03/1967. La Victoria/Lima: Male appears daily in the open garage, attracted by his own image, reflected in one of the wheel caps. He promenades in front of it and occ. jumps against his mirror image, mostly twice in succession. The clicking sound is largely audible. The 'attacks', which do not seem to be an act of aggression, but merely a reflex, may last 15-30 min.

27-29/07/1967. Cajatambo, Pativilca Valley, Lima, 3400 m: In large numbers in the grainfields surrounding the village.

17-18/02/1967. Machu Picchu, Cusco, 2400 m: Nest-building behind the hotel in a dense grass bush. The female is carrying small twigs to the concealed place as inconspicuously as possible, while her mate is singing incessantly from a nearby perch.

27/08/1967. Lomas de Pacta, $45 \mathrm{~km}$ south of Lima: Nest with young in a densely foliated Carica, about $2.20 \mathrm{~m}$ above the ground. An ad. keeps watch.

Mid November 1967. Miraflores/Lima: Ind. foraging in the garden (maybe gathering food for young), scratching in a chicken-like manner amongst dry leaves or standing with both feet upon a clod and turning it upside down by jerkely jumping backwards.

24/08/1969. Lomas de Lachay, $70 \mathrm{~km}$ north of Lima, $400 \mathrm{~m}$ : Most common species in the park-like area with rocks and trees. Foodcarrying ind. hopping around in a Caesalpinia. - Nest with 3 eggs on the ground beneath a low scrub in the open zone without trees (Fig. 137). It is made of grass stems and lined with wool. The rim is draped with moss. Outer diam $13 \mathrm{~cm}$, inner diam. $6 \mathrm{~cm}$, depth $4,5 \mathrm{~cm}$. The light green eggs are strewn with light and dark brown spots. They vary in degree of the background color and the arrangement of the spots.

Measures: $21,5 \times 16 / 23 \times 16 / 22 \times 16 \mathrm{~mm}$.

25/11 - 05/12/1969. Miraflores/Lima: 10:30-13:00: Intense nest- building activity in a hedge of pomegranates. Both ads. participate by contributing dry leaves, stems and twigs. When an ind. discovers my presence it immediately drops a full load of stems. - No activity during the following two days.

29/11. Two eggs have been deposited before $3 \mathrm{pm}$.

$30 / 11$. Ad. breeding at $10 \mathrm{am}$.

01/12. $3^{\text {rd }}$ egg deposited before 12:30.

05/12. Hutch abandoned. Eggs greenish with brown spots: $24 \times 19 / 21 \times 16 / 21 \times 16 \mathrm{~mm}$.

28/02/2003. San Borja/Lima: Ind. foraging in a small garden beneath ornamental plants, where it scratches vigorously in the earth, pausing from time to time, looking for prey.

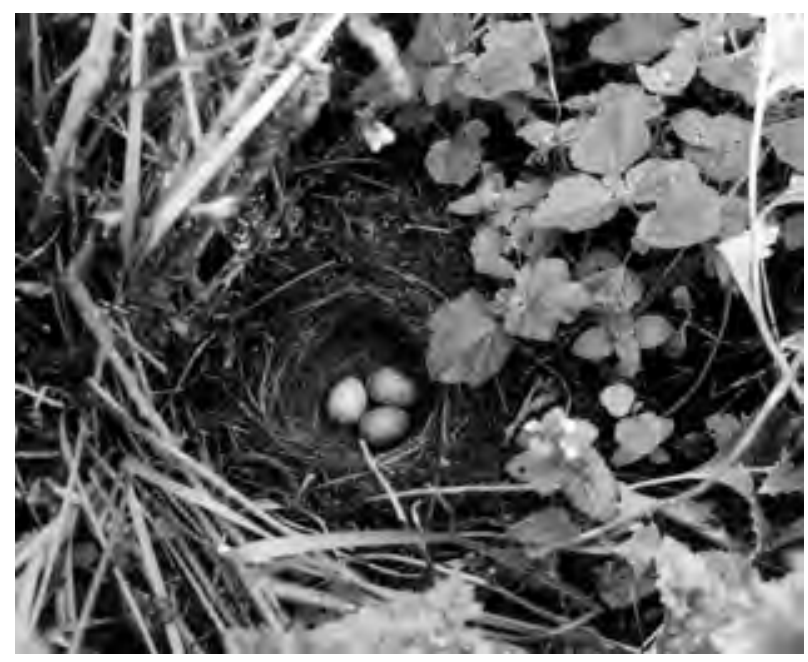

Figure 137. Zonotrichia capensis: nest with clutch.

\section{Phrygilus punensis}

\section{Sightings}

NP: west slope: Cajamarca 2800/3200 m; east slope: Cajamrca $2600 \mathrm{~m}$.

CP: west slope: Ancash 3000-3600 m; Lima 3000-4300 m; east slope: Pasco 3000-3300 m; Huánuco $3100 \mathrm{~m}$.

SP: Arequipa 3400 m; Cusco 3000 m; Puno 3900-4100 m.

25/05/1967. Viso, Rímac Valley, Lima, 3000 m: Small village consisting of adobe houses. Nest with young beneath roof of corrugated sheet iron; ad. feeding.

26/04/1969. Chumcha, Santa Eulalia Valley, Lima, 3400 m: Steep slope with lush vegetation (semi-humid montane scrub). Thickwalled, densely woven Nest with only one fledgling on an Opuntia (Fig. 138/139). Horizontal distance from slope $1.5 \mathrm{~m}$. Nest consists

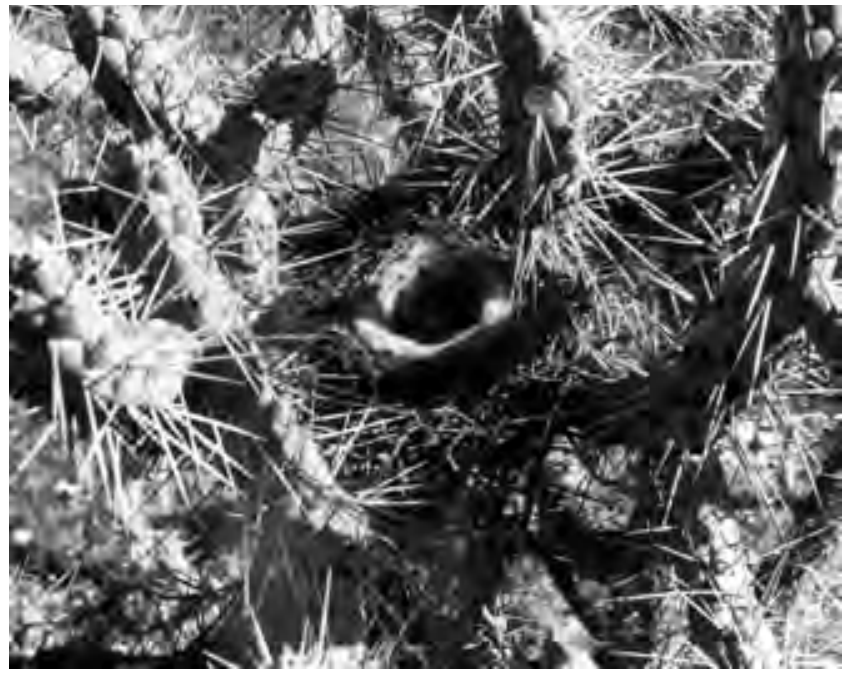

Figure 138. Phrygilus punensis: nest with nestling. 


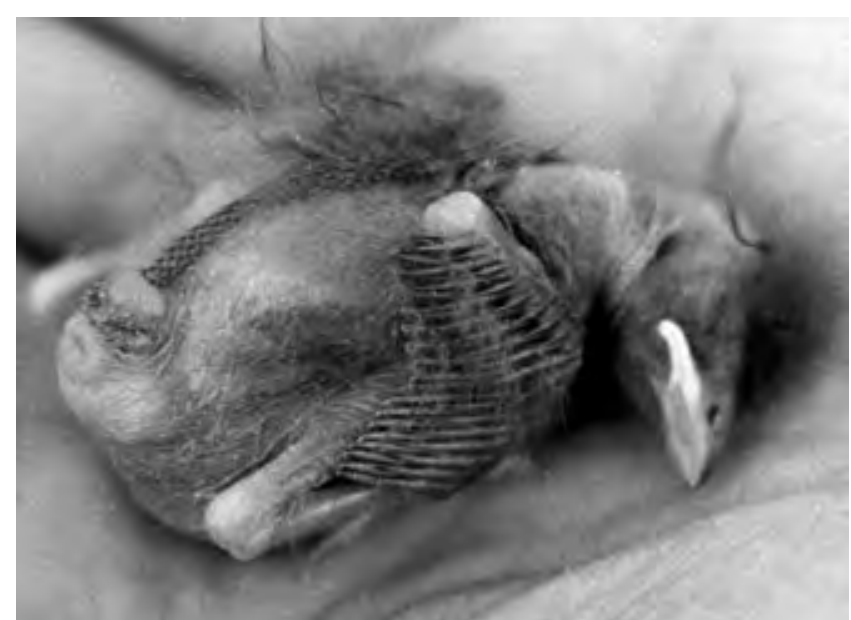

Figure 139. Nestling of Phrygilus punensis.

of delicate roots and stems on a base of coarse twigs and branches. Interior: sheep (?) wool with some horse hairs. Outer diam. approx. $15 \mathrm{~cm}$, inner diam. $8 \mathrm{~cm}$. After feeding, ad. deposits a fecal sac on top of another Opuntia about $200 \mathrm{~m}$ away.

07/04/2003. Acopalca near Huari, Ancash, 3300 m: Female gathering nesting material on the ground, then departs with a tuft of small stalks.

\section{Phrygilus fruticeti}

\section{Sightings}

NP: Cajamarca, 2700/3400 m; La Libertad, 2800-3600 m

CP: Ancash, 3000-3500 m; Lima 2200-4200 m (most frequent between 3000-3800 m)

\section{SP: Arequipa, 3400-3500 m; Puno, 3900 m}

Habitat.- Semi-humid montane scrub with cacti; fields and pasture land with hedgerows and stonewalls; Polylepis wood.

Courting/Breeding.- The main courting period in Lima begins in $\mathrm{Feb}$ and ends in June. A second, less active period, lasts from August to November. Young recorded in Apr, May, June and Dec.

Voice.- No other bird in the montane scrub zone is such an eager and tireless singer as Ph. fruticeti During the mating season it can be heard all day long, even on foggy or rainy days. Males emit their distinctive song - a cascade of blurred notes - from conspicuous perches, such as rocks, bushes or cacti. They sing occ. during gliding phase of (display?) flight.

31/10 - 01/11/1965. Chumcha, Santa Eulalia Valley, Lima, 3600 $3800 \mathrm{~m}$ : There is an increase of song activity before sundown ending shortly thereafter (17:45-18:15). Morning song begins (timidly) shortly before sunrise.

16/05/1970. Casta, Santa Eulalia Valley, Lima, 3400 m: Song everywhere. Begging young in montane scrub with Opuntia. Ad. warns repeatedly with a metallic pick. Male with nesting material. Up to five males can be heard at the same time. Some of them get occ. into territorial disputes.

24/04/1971. Chumcha, 3600-3800 m: Intense song activity in lush montane scrub. Neighbouring males do not sing simultaneously. When one of them stops, another begins. The songs may overlap with those of other ind. farther away (Fig. 140/141).

01-08/09/1972. Casta, 3100-3900 m: Numerous in montane scrub with Opuntia. One of the few species to be heard, esp. in the morning and in late afternoon. - $3800 \mathrm{~m}$ : Short, but general outburst of song activity at sunrise (07:15).

\section{Phrygilus alaudinus}

\section{Sightings}
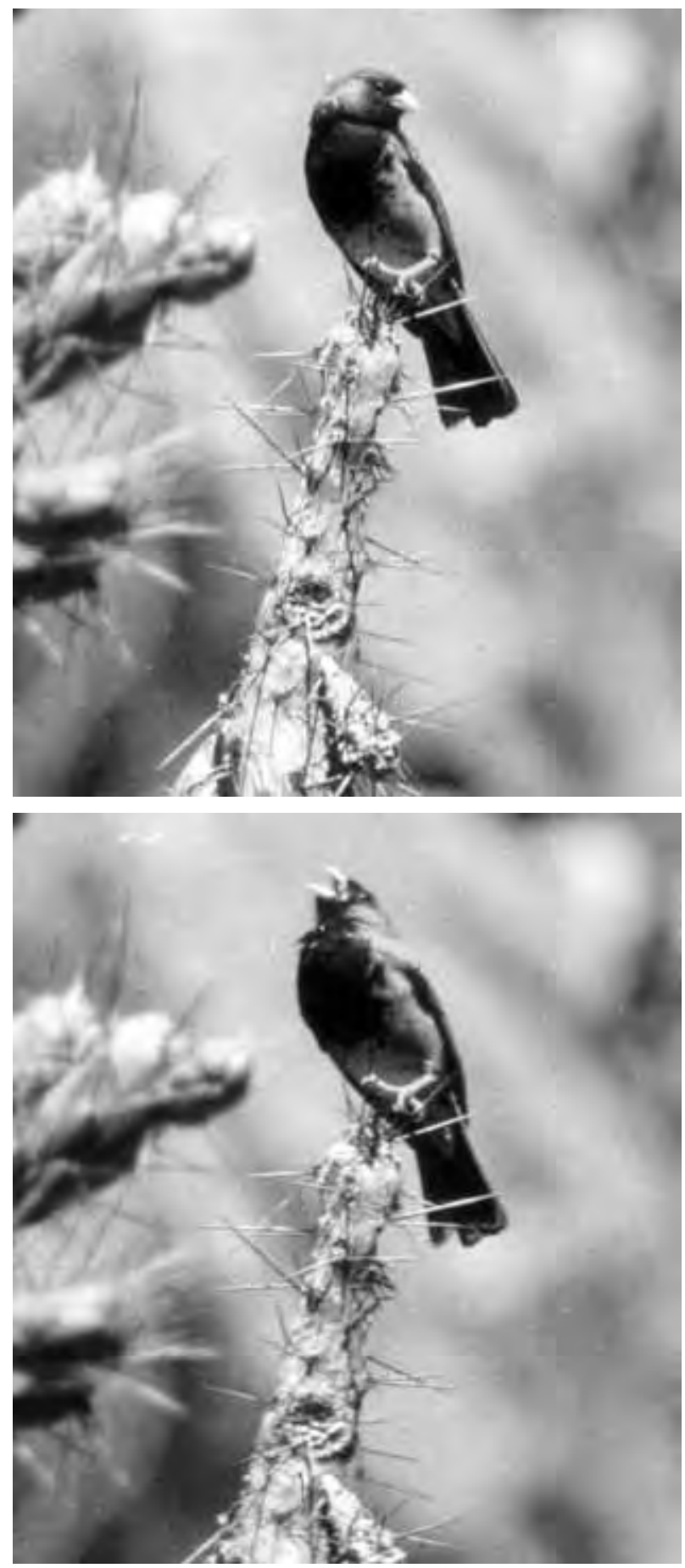

Figure 140 - 141. Phrygilus fruticeti.

\section{NP: Cajamarca, 2800/3000m; La Libertad 1800 m}

CP: Lima, 400-2000 m (most records in the lomas)

SP: Cusco, 3600 m; Puno, 3900 m

10/10/1965. Lomas de Pacta, 45 km south of Lima: Fairly common; lively courting activity Song emitted when perched on a stone, during display flight (Fig. 142) or even when feeding on the ground.

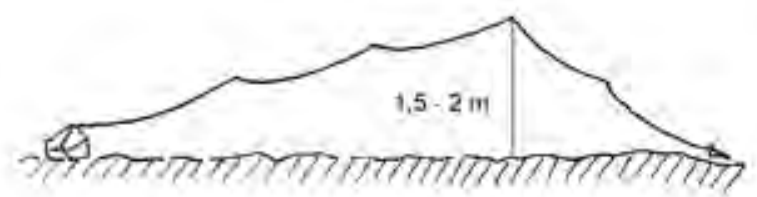

Figure 142. Phrygilus alaudinus: display flight. 


\section{Diuca speculifera}

\section{Sightings}

CP: Lima: Huaura Valley 4200 m; Canta Valley 4500 m; Santa Eulalia Valley 4400-4700 m

SP: Puno: Ananea, $4800 \mathrm{~m}$.

\section{Xenospingus concolor}

17-21/02/1999. Samaca, Ica Valley, Ica, 200 m: On two occ. ind. in riparian vegetation, hopping leisurely through Prosopis thicket, examining foliage in search of insects. Song: A slightly ondulating series of short, intermittent syllables. - Juv. on Prosopis.

\section{Incaspiza pulchra}

\section{Sightings/Habitat}

Lima: Rímac Valley, 1800/2200 m; Lurin Valley, 1600-2200 m; in dry montane scrub with cacti, Jatropha and Carica and scree-strewn slopes with scarce vegetation.

Voice.- Whistle (see BP) sometimes followed by a trill at a lower pitch.

25/05/1963. Above Ricardo Palma, left side of Rímac Valley, Lima, 1800-2000 m: Fairly numerous in an arid quebrada with sparse vegetation. Often in pairs; foraging on seeds on the ground. (Probably) young hidden in scrub, begging.

26/09/1964. Quebrada Tinajas, Lurin Valley, Lima, 2000 m: Ind. feeding on unripe cactus fruit.

\section{Poospiza caesar}

12/06/1968. Between Illahuasi and Rio Pampas (Puente Santa Rosa), Apurímac, 3000-3200 m: Several sightings in the dense montane scrub with scattered patches of agricultural fields. Melodious song emitted from elevated perch.

20/07/1988. Paucartambo, Cusco, 3000 m: In dense montane scrub with cacti at the edge of the village.

\section{Poospiza hispaniolensis}

Sightings.- Mainly on west slope of Central Peru: Ancash 1300 m; Lima 0-2400 m (Canta, Rímac, Mala Valleys)

15/02/1964. Sauce Grande, Amotape Mountains, Piura, 600 m: Female gathering food on the surface of a cracked rock, slipping in and out of the crevices.

27/03/1964. Urbanización California, Chosica, Lima, 800 m: Numerous in dry scrub with Acacia and rich vegetation along irrigation channel. Often in pairs. When flying from scrub to scrub, they seek cover immediately. Males singing on low perches. One of them straightens his plumage after every sequence. The same procedure recorded two weeks later at the mouth of the Rio Chillón.

\section{Volatinia jacarina}

The diagram and the following records refer to gardens and parks of La Victoria/Lima and Miraflores/Lima.

Courting.- Courting activity takes place year round. The 'proper' reproduction period (breeding and feeding at nest) lasts roughly from

Preproductive periods of Volatinia jacarina

\begin{tabular}{|c|c|c|c|c|c|c|c|c|c|c|c|c|}
\hline & 1 & 2 & 3 & 4 & 5 & 6 & 7 & 8 & 9 & 10 & 11 & 12 \\
\hline c & & $\ldots$ & -1 & . & $\cdots$ & $\cdots$ & $\cdots$ & & $\cdots$ & $\cdots$ & . & -- \\
\hline $\mathrm{n}$ & -- & & & & & & & 1 & & & & -- \\
\hline$b$ & \begin{tabular}{|l|} 
\\
\end{tabular} & & 1 & & --- & & & & -- & & | & I- \\
\hline $\mathrm{fn}$ & . & -- & |.- & - & 1 & & & 1 & & - & 11 & 1 ... \\
\hline fo & & -- & & 111 & -- & & 11 & & & $\|$ & & 111 \\
\hline
\end{tabular}

Figure 143. 1-12: month/year; c: courting activity (display flight and song); n: nest-buil ding; b: breeding; fn: feeding at nest; fo: feeding outside nest; | single record; --- observation period.
Sep to June, probably including two or more reproduction cycles. The display flight of $V$. jacarina should be called more properly display leap - considering its height of $30-50 \mathrm{~cm}$. It is generally performed from low perches, as poles, bushes or grass stems, occ. from trees or edges of roofs; also on the ground (especially in the presence of a female). The song - emitted with or without leap - consists of a short, pressed sequence that sounds like tswiryew. It is repeated 20-30 times per minute. Three or four males may gather for a kind of song competition (min. distance between two ind.: $10 \mathrm{~m}$ ).

Nesting sites.- Volatinia jacarina prefers hedges, bushes and creepers to build its nest; mostly below $2 \mathrm{~m}$ above ground (lowest site $30 \mathrm{~cm}$, highest about $4 \mathrm{~m}$ ). I have found nests on the following plants: Geranium $0,9 / 0,5 \mathrm{~m}$, lluvia de oro $2 / 2,5 \mathrm{~m}$, bamboo $1,6 \mathrm{~m}$, rose $0,5 / 1 / 1,2$ $\mathrm{m}$, pomegranate $2 / 2 / 1 \mathrm{~m}$, Acacia dealbata $4 / 4 \mathrm{~m}$, Fuchsia $0,8 \mathrm{~m}$, Vicia $0,9 \mathrm{~m}$, cotton $0,30 \mathrm{~m}$, Nerium $2 \mathrm{~m}$.

\section{Reproduction statistics}

Number of eggs/young: 2 (6x), 3 (4x)

Nest-building 6-7 days

Breeding 10-11 days

Feeding at nest 10-14 days

End of March/Beginning of April 1963, La Victoria: Lively courting activity in a cotton field. Songs and display flight on top of the cotton bushes. Mixed groups of males and females pursuing each other. - Male and female feeding young.

27/04/1963. Same place: Male feeding Molothrus bonariensis double his size. Another ad. feeding its own breed.

May 1963. Miraflores: Brood in a garden on Geranium close to a brick wall, $90 \mathrm{~cm}$ above the ground. The thin walled nest consists of loosely aligned grass roots, inside lined with horse hair. Two eggs with dark brown spots, concentrated around broad pole (Fig. 144), laid 0405/05/1963; hatched 17-18/05/1963 (Fig. 145); fledged end of May.

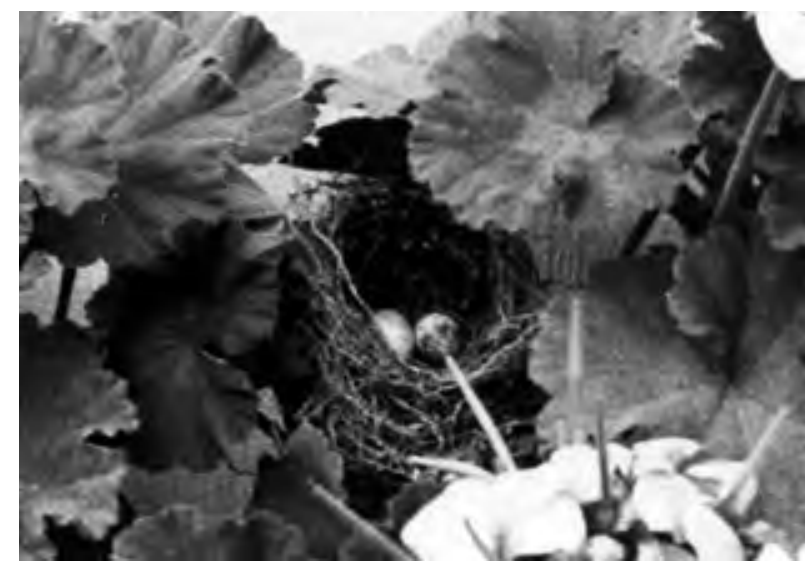

Figure 144. Volatinia jacarina: nest with cluch.

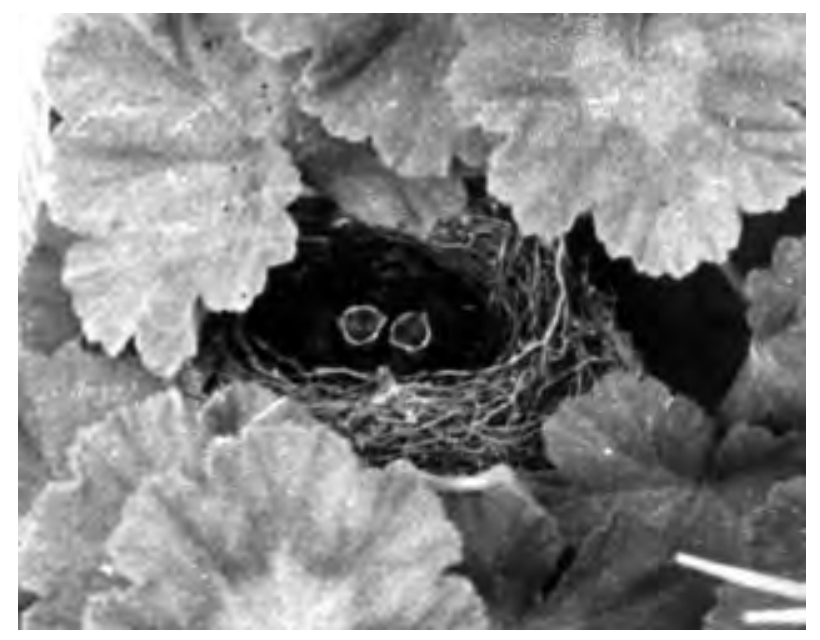

Figure 145. Volatinia jacarina: nestlings 3-4 days old. 
01/10/1963. La Victoria: Pair on lawn; male approaches female in a provocative manner, singing excitedly.

Beginning of Nov 1963 Miraflores: Pair beneath a hedge. The male grabs a small leaf and hops ahead of the female. He seems to invite her to follow him (and build a nest?).

11/04/1964. Mouth of Rio Chillón, Lima: Female feeding a nearly full grown Molothrus bonariensis.

Breeding record 08/12/1964 - 03/01/1965, La Victoria:

$08 / 12 / 1964$. Pair lingering in a lluvia de oro at their future nesting site.

\section{0/12/1964. Summary of protocol, 14:30-16:30}

Nest-building in full swing. The main task of the male is to provide the nesting material, as grass stems and grass roots (Fig. 146). 13 of 15 entries made in two hours correspond to the male. If the female is present, he passes the material to her; if she is absent, he fixes it only superfically. He often anounces his arrival with song and flight display at the edge of the roof or on the garden wall. He repeats the ceremony, when leaving the site. The female, sitting in the nest most of the time, is occupied with properly fixing the material, provided to her by her mate. By turning constantly around, she gives the nest its accurate form and size. On two occ. she returnes to the nest with pieces of cotton (Fig. 147) and fixes them on the outside. Call emitted by both genders: A sharp tsic or tshewc, that possibly serves to establish or maintain contact. - The building phase lasted about 6 days, with decreasing intensity towards the end.

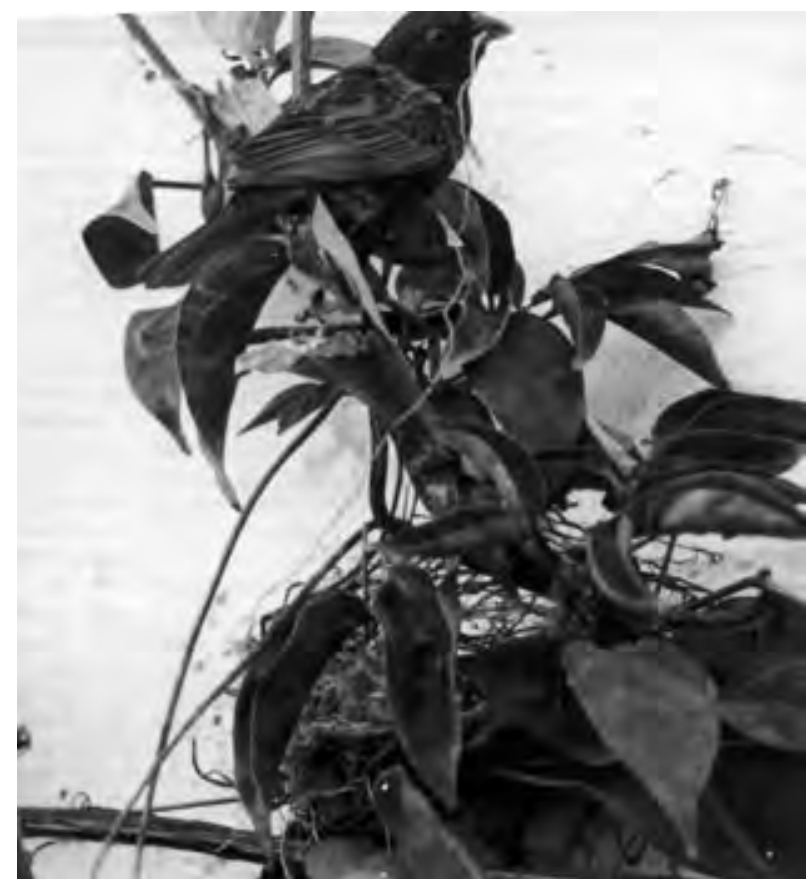

Figure 146. Volatinia jacarina: male nest-building.

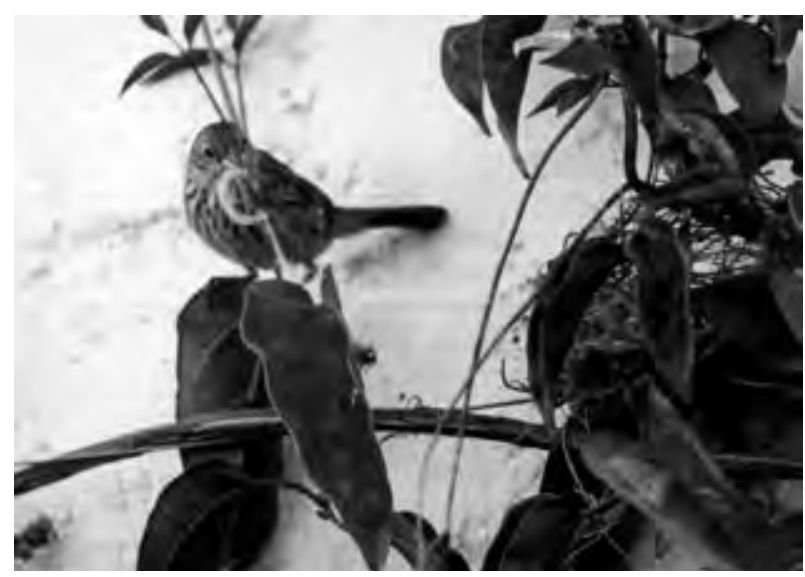

Figure 147. Volatinia jacarina: female nest-building.
$16-17 / 12 / 1964.1^{\text {st }}$ and $2^{\text {nd }}$ egg laid before 7.30 am at a 24 -hour interval; $12 \times 14 / 11,5 \times 14,5 \mathrm{~mm}$. Only the female is breeding; nest is occ. left unguarded.

26-27/12/1964. The young hatch between evening of 26 and morning of 27 December.

Both ads. participate in the feeding. The male is the main provider of food. Guarding and protecting the young is the exclusive task of the female. The food in most cases is not carried in the bill, but stored in the crop (Fig. 148).

When the male approaches the nest, he occ. emits - despite the fully crammed throat - his courting song. He anounces his coming with a soft tsic'tsic and his mate answers likewise. A mutual greeting ceremony follows, consisting of an excited and rapid series of tsic'tsic'tshewc'tshewc. While the male regurgitates the food, the female flies away. The young stay unguarded for some minutes, until the female returns from her food-hunting trip. Before and during the feeding, the young emit begging sounds. If they are warned by the ad., they fall silent immediately.

28/12/1964. Feeding protocol 13:40-14:25

\begin{tabular}{|c|c|c|}
\hline$\leftrightarrow$ & \multirow{2}{*}{\multicolumn{2}{|c|}{$\begin{array}{l}\text { feeding and leaving } \\
\text { feeding and staying }\end{array}$}} \\
\hline$\infty$ & & \\
\hline$\rightarrow$ & leaving & \\
\hline+ & present & \\
\hline - & absent & \\
\hline 13:42 & $\widehat{\delta} \leftrightarrow$ & q- \\
\hline 13:50 & & $\delta^{t}-$ \\
\hline 14:02 & $\hat{\sigma} \leftrightarrow$ & $\phi \rightarrow$ \\
\hline $14: 13$ & $q_{\infty}$ & $\delta^{\lambda}-$ \\
\hline $14: 19$ & $\hat{\sigma} \leftrightarrow$ & o+ \\
\hline
\end{tabular}

Feeding every 9 min, male and female alternating

01/01/1965. Feeding protocol 13:15-14:05

\begin{tabular}{|c|c|}
\hline $13: 18$ & $q_{\infty}$ \\
\hline $13: 22$ & $\partial \leftrightarrow$ \\
\hline $13: 27$ & $\hat{\sigma} \leftrightarrow$ \\
\hline $13: 31$ & $q \leftrightarrow \mathrm{fs}$ \\
\hline $13: 33$ & $\hat{\sigma} \leftrightarrow$ \\
\hline 13:40 & $\delta \leftrightarrow$ \\
\hline $3: 4$ & \\
\hline $\begin{array}{l}14: 04 \\
\text { fs. }\end{array}$ & \\
\hline
\end{tabular}

Feeding every 6-7 min; male five, female three entries.

03/01/1965. Tense moment on the edge of the roof: A singing and rattling Troglodytes aedon perched between two pairs of $V$. jacarina, only $4 \mathrm{~m}$ apart. 'Our' $V$. Jacarina pair does not hesitate to drive away both intruders. On two occ., T. Aedon gets inadvertently into the vicinity of the Volatinia-brood. Both ads. attack the alleged enemy with hue and cry. T. aedon is not really impressed.

20/08/1965. La Victoria: Ind. on a blooming Poinsettia. It dips its bill into the tiny cups, filled with nectar $(\rightarrow$ Sporophila simplex).

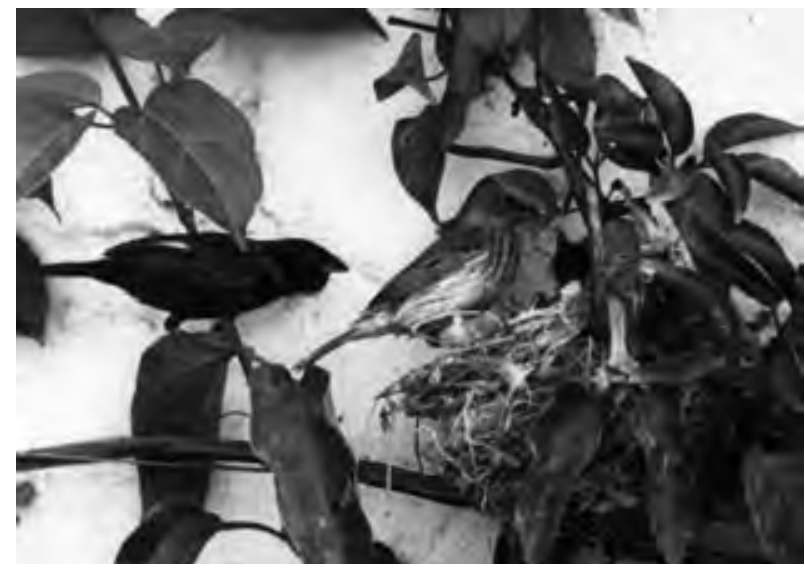

Figure 148. Volatinia jacarina: male and female feeding at nest. 
12/12/1965. La Victoria: Brood on Acacia dealbata in a vertical crutch. Daily begging calls.

15/12/1965. Same place: Full-fledged young gets fed repeatedly by a female.

16/12/1965. Same place: Two females feeding at the same time; one of them young at nest, the other her almost grown-up offspring. On one occ., both females feed consecutively at nest.

05/03/1969. Miraflores: Nest-building in a cotton field, $30 \mathrm{~cm}$ above the ground. At the moment, the nest consists only of a few grassroots, draped with some patches of spiderweb.

17/08/1971. Miraflores: Female on a bare-branched poplar, picking out nesting material of a seemingly unused nest. She disappears with it to a neighbouring garden.

28/02/2003. San Borja/Lima: Male gathering nesting material. He successfully manages to form a loop out of a long vegetal fiber.

\section{Sporophila luctuosa}

05/04/2003. Chavín de Huántar, Ancash, 3200 m: Group in a cornfield, feeding on the seeds of a $1 \mathrm{~m}$-high Brassicacea. To reach the pods, they cling to a nearby corn leaf

08/04/2003. San Luis, Ancash, 3000-3300 m: Fairly common in the rich montane scrub with Genista. Song: A varied sequence of whistles, trills and fricatives.

\section{Sporophila nigricollis}

05/03/1972. Sócota, Cajamarca, $2100 \mathrm{~m}$ : Male singing in a hedgerow. Hamonious song, resembling that of Sporophila telasco.

05/07/1972. San Ramón, Chanchamayo Valley, Junín, 800 m: Ind. in second growth.

\section{Sporophila simplex}

Sightings.- Lima: Canta Valley 500 m, Rímac Valley 800 m; Ancash: Nepeña Valley, $200 \mathrm{~m}$.

Habitat.- Gardens and parks, fallow land, scrub and bush vegetation along cultivated fields and irrigation channels.

Behavior.- Gregarious; in flocks of up to 30 inds.; occ. in company with other finches. Forages mainly in low vegetation as scrub and weed; also on the ground.

Voice/Courting .- Song: A rich, varied chatter of different length, beginning with a soft introduction, followed by a more intense middle part, decreasing at the end or ending with a rushing sequence. Uses all kinds of perches, like bushes, trees, grass stems, stakes; also singing in flight. Song activity begins in Miraflores/Lima in Sep, reaches its culmination in Oct and ends in Dec. In Chosica, Rímac Valley, Lima (Urbanización California, $800 \mathrm{~m}$ ) there seem to be two courting seasons: Jan to April and Aug to Oct.

Feeding.- Apart from seeds and grains, S. simplex has developed - at least in the gardens and parks of Lima - a special liking for nectar. It has found ingenious ways to reach the sought-after juice, as the following examples demonstrate:

1) Ind. visits repeatedly the blossoms of Poinsettia, dipping its bill into the tiny bowls filled with nectar, then rising its head slightly in a drinking manner. Occ. it cleans its bill from the sticky stuff by rubbing it off on a branch $(\rightarrow$ Volatinia jacarina)

2) Ind. visits repeatedly the pierced blossoms of Hibiscus (Fig. 149). The holes must be the work of $S$. Simplex, created to reach the otherwise inaccessible nectar. Amazilia amazilia is also making use of them.

3) Small group in orchard with blooming peach trees; ind. feeding on nectar.

4) Ind. on a red Salvia, plucking the flowers and squeezing the nectar-filled end ( $\rightarrow$ Carduelis magellanicus).

\section{Sporophila telasco}

Sightings.- Coastal valleys from Lambayeque to Ica up to $800 \mathrm{~m}$ (Rímac Valley); east slope: Chamaya Valley, Cajamarca, $800 \mathrm{~m}$.

Habitat.- Riparian vegetation, dry scrub with Acacia, fallow land, cotton, rice and corn fields, totorales, gardens and parks.

Voice/Courting.- Pleasant, uninterrupted chatter, that lasts several seconds; emitted from scrub, grass stems, corn and cotton plants, Acacia trees and telephone wires; also in flight. Song activity begins in Nov, is most intense from Jan to Mar and ends in April.

20/02/1967. Nest with egg outside Lima in a tall grass bush about $1,5 \mathrm{~m}$ above ground. A light, transparent structure made of grass stems, grass roots and panicles mixed with some patches of cotton. Outer diam. $7 \mathrm{~cm}$, inner diam. $4 \mathrm{~cm}$, height $5,5 \mathrm{~cm}$, depth $4,5 \mathrm{~cm}$. Egg: white with black dots, forming a ring around broad pole; $12,5 \times 17,5 \mathrm{~mm}$.

\section{Catamenia analis}

Sightings.-

NP: Marañón Valley, La Libertad, east-facing slope, 2400 m (BP: "in intramontane valleys not below $3000 \mathrm{~m}$ on east-facing slope")

CP: west slope: Ancash and Lima from sealevel to $3500 \mathrm{~m}$; east slope: Junín 3000-3300 m

\section{SP: Cusco and Apurímac 3000-3300 m}

Behavior.- Gregarious; sometimes in mixed groups with Sporophlia telasco and Sporophila simplex. Constantly roaming about in low vegetation (bushes, herbs, grass) in search of seeds; also on the ground.

09/04/2003. San Luis, Ancash, $3000 \mathrm{~m}$ : Male uses special technique to get at the seeds on top of $1 \mathrm{~m}$-high grass stems: He alights on a spike, tearing it down to earth by its own weight. Hastily, he begins to pluck the seeds. First he has to free them from the indigestible cover by nibbling and turning them in his bill. After having repeated the catchin-flight procedure, he manages to reach a spike from a nearby scrub.

\section{Arremon abeillei}

17/02/1964. Sauce Grande, Amotape Mountains, Piura, 800 m: Ind. in undergrowth of deciduous forest.

\section{Atlapetes latinuchus}

\section{Sightings}

NP: west slope: Yumagual $2800 \mathrm{~m}$ and Chetilla $2800 \mathrm{~m}$, Jequetepeque Valley, Cajamarca; east slope: Aricapampa, Marañón Valley, La Libertad, 2400 m; between Sócota 2000 m and San Andrés de Cutervo 2400 m, Cajamarca.

Habitat.- Humid montane forest, riparian vegetation and second growth.

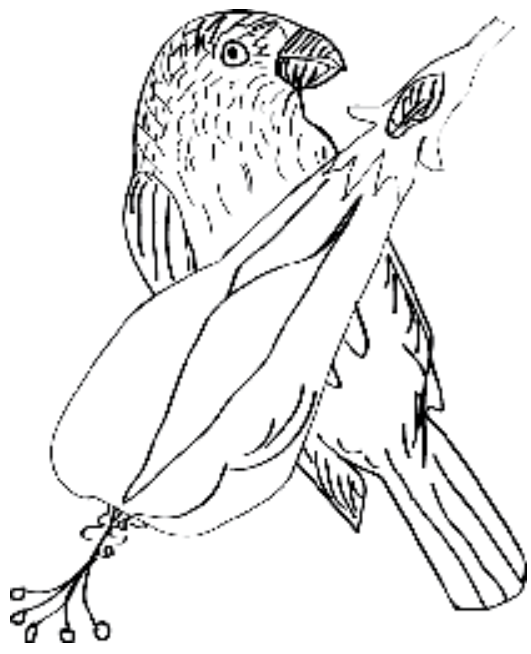

Figure 149. Sporophila simplex: feeding on nectar. 


\section{Atlapetes rufigenis}

28/06/1965. Between Yungay and Yanganuco, Ancash, 3000-3600 $\mathrm{m}$ : Several sightings in the humid montane scrub.

\section{Atlapetes albiceps}

16/02/1964. Sauce Grande, Amotape Mountains, Piura, 600-800 $\mathrm{m}$ : Fairly common in deciduous forest; often in pairs or small groups.

January 1967. Between Olmos and Abra Porculla, Lambayeque, 700 $\mathrm{m}$ : Ind. in deciduous forest, avidly scratching the ground.

\section{Atlapetes nationi}

Sightings.- Lima; most records between 2500 an 3500 m; min. alt. 2100 m, Rímac Valley; max. alt. 4200 m, Santa Eulalia Valley

Behavior.- Not shy; often on the ground in search of food, scratching noisily in dead leaves.

Habitat.- Dry and semi-humid montane scrub, humid montane forest, Polylepis wood, cultivated areas with hedges and stonewalls; near and occ. within villages. A. nationi thrives in lush montane scrub with cacti and scattered trees.

15/09/1963. Zárate, Rímac Valley, Lima, 3000 m: Ind. feeding on Oreopanax blossoms.

03/12/1966. Chumcha, Santa Eulalia Valley, Lima, 3300 m: Ind. examining horse or donkey droppings during several minutes.

24/04/1971. Chumcha, $3900 \mathrm{~m}$ : Ind. in Polylepis wood feeding on a Phrygilanthus berry. It squeezes the fruit, until the sticky seed drops out, then swallows the rest.

\section{Cardinalidae}

\section{Piranga flava}

\section{Sightings}

NP: east slope: San Andrés de Cutervo, Cajamarca, 2400 m; Aricapampa, Maranón Valley, La Libertad, 2400 m.

CP: west slope: Chiuchín, Huaura Valley, Lima, 2600 m; Colca, Fortaleza Valley, Lima, 2500 m; Chancay Valley, Lima, 1800 m; Lurin Valley, Lima, 600/1500 m.

\section{Pheucticus chrysogaster}

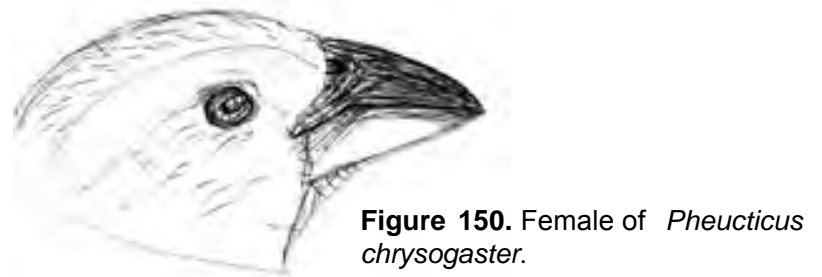

\section{Sightings}

NP: west slope: $200-1000 / 2800 \mathrm{~m}$; east slope: $1500-2800 \mathrm{~m}$

CP: west slope: 1000-3500 m (most frequent between 1700-3200 $\mathrm{m}$ ); east slope: $2600-3400 \mathrm{~m}$

SP: west slope: 2200-3400 m; southernmost record: Torata, Moquegua (BP: Distribution map shows Ph. chrysogaster reaching only to northern Arequipa).

Habitat/Behavior.- Orchards and small cultivated plots, pasture land with hedgerows, Eucalyptus groves, humid montane scrub, riparian vegetation, second growth, deciduous forest. Fruit and seed eater: Schinus molle, Salix humboldtiana, Acacia macracantha, Prunus serotina.

23/03/1970. Between San Bartolomé and Zárate, Rímac Valley, Lima, 2300-2600m: Song and breeding activity in lush montane scrub. Male with nesting material (long grass stem). $2300 \mathrm{~m}$ : Nest with 3 eggs on a horizontal branch of Carica at 1,80 m above ground (Fig.
151); female breeding. Nest consists of dry twigs, grass stems and other vegetal fibers. Smooth interior contrasts with tangled outside. Inner diam. $8,5 \mathrm{~cm}$, outer diam. 25-30 cm, depth $5 \mathrm{~cm}$. Eggs: Turquois with light and dark brown spots and uniform brown patch on broader pole. Sample egg: 19x30 mm.

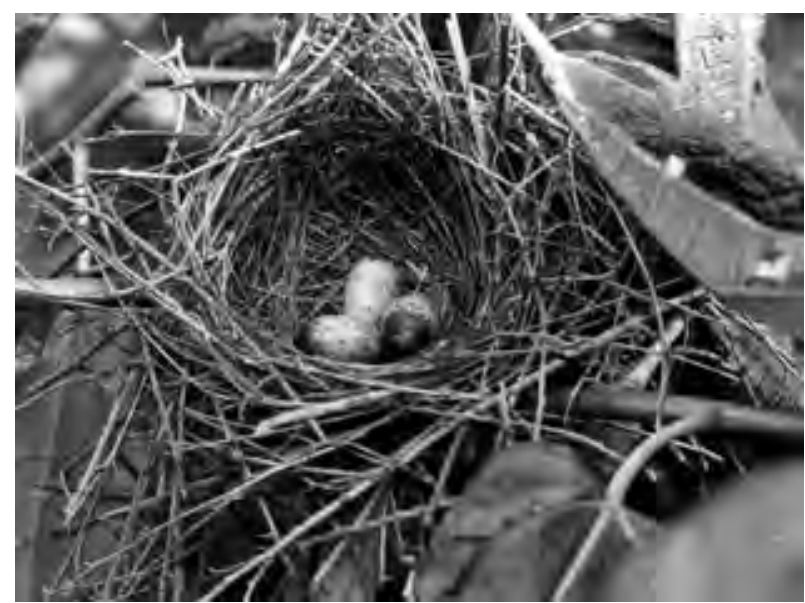

Figure 151. Pheucticus chrysogaster: nest with clutch.

\section{Pheucticus aureoventris}

11/06/1968. Hacienda Toxama, north of Andahuaylas, Apurímac, $2400 \mathrm{~m}$ : Numerous in orange and chirimoya orchards.

14/06/1968. Between Puente Santa Rosa and Mollebamba, Pampas Cañon, Ayacucho, $1800 \mathrm{~m}$ : Male in dry but dense montane scrub with scattered trees.

21/07/1976. Limatambo, Cusco, 2500-2900 m: In dense montane scrub.

\section{PARULIDAE}

\section{Parula pitiayumi}

16/02/1964. Sauce Grande, Amotape Mountains, Piura, 600 m: Small group in deciduous forest near water hole.

\section{Wilsonia canadiensis}

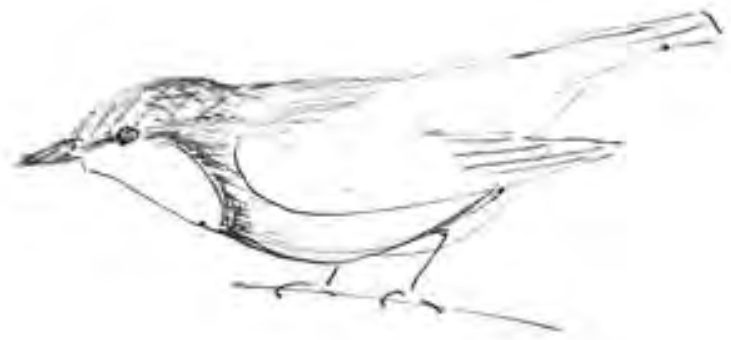

Figure 152. Wilsonia canadiensis.

04/03/1972. San Andrés de Cutervo, Cajamarca, 2400 m: Ind. foraging in an isolated patch of humid montane forest. It pursues a white moth in zigzag-flight, catches and swallows it, perched on a bush.

\section{Geothlypis aequinoctialis}

03/08/1966. Aricapampa, Marañón Valley, La Libertad, 2400 m: Ind. in a quebrada with dense vegetation foraging on the ground.

01/10/1967. Canta Valley, Lima, 500 m: Female on a Casuarina at the edge of a peach orchard.

17/11/1968. Mouth of Rio Mala, Lima: Male in an extended patch of Tessaria.

\section{Myioborus miniatus}

05/01/1965. Between Olmos and Abra Porculla, Lambayeque, 1500 $\mathrm{m}$ : Ind. foraging in scrub and deciduous forest. 
29/07/1965. Huacamochal, Chicama Valley, La Libertad, 1700 m: Several sightings in montane scrub.

28/09/1971. Contumazá, Cajamarca, 2700 m: Ind. in an Eucalyptus grove, busily hopping from branch to branch in search of insects. It spreads in flight its long black and white tail. - Pair in scrub thicket, hopping around and spreading their tails. The outer tail feathers are shining in the semi-darkness (part of courting display?).

31/07/1976. Yumagual, Jequetepeque Valley, Cajamarca, $2800 \mathrm{~m}$ : Fairly common in humid montane scrub and forest relic. Attracted by a swarm of insects, that are swirling over a fresh cow dung, ind. jumps for prey from a low perch or from the ground.

20/07/1983. Pucatambo, west of Rioja, Amazonas/San Martín, $1600 \mathrm{~m}$ : Ind. foraging in canopy of primary forest.

\section{Myioborus melanocephalus}

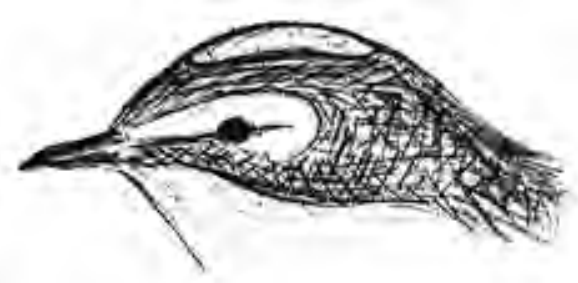

Figure 153. Myioborus melanocephalus.

17-19/09/1968. Rio Paucartambo, Pasco, 2600 m: Small group roaming through riparian vegetation, jump-gleaning for insects.

02-03/03/1972. San Andrés de Cutervo, Cajamarca, 2500 m: Ind. at the edge of the humid forest and in second growth.

22/01/1999. Chetilla, Jequetepeque Valley, Cajamarca, $2800 \mathrm{~m}$ : Several inds. foraging in riparian thicket.

\section{Basileuterus nigrocristatus}

29/09/1971. Contumazá, Cajamarca, $2700 \mathrm{~m}$ : Ind in riparian vegetation (Alnus).Vivacious; even when sitting on a branch and singing, it stirs restlessly to and fro.

10/07/1993. Pataz, east slope of Marañón Valley, La Libertad, 2700 $\mathrm{m}: 3$ ind. in a quebrada with brook and dense vegetation.

22/01/1999. Chetilla, Jequetepeque Valley, Cajamarca, $2800 \mathrm{~m}$ : Ind. foraging in lush riparian vegetation.

\section{Basileuterus trifasciatus}

25/07 - 02/08/1965. Coina, Chicama Valley, La Libertad, 1500 $\mathrm{m}$ : Fairly common in a quebrada with abundant vegetation. Often in small groups of 4-5 ind. (Coina is possibly the southernmost point of distribution.)

22/01/1999. Chetilla, Jequetepeque Valley, Cajamarca, $2800 \mathrm{~m}$ : Several ind. move incessantly through thicket of lush riparian vegetation in search of insects.

\section{ICTERIDAE}

\section{Psarocolius angustifrons}

12/01/1970. Rio Pachitea, between Tournavista and mouth of Rio Llullapichis, Huánuco, $300 \mathrm{~m}$ : Courtship and nest-building in a breeding colony: Singing male performing its acrobatic display (Fig. 154). A nearby female is avidly gathering nesting material. She picks out fibers of an old or abandoned nest, chooses carefully the most suitable ones by clinging to a branch, sometimes head down, even on one foot. The male is hopping about eagerly, trying in vain to attract the attention of the female. Meanwhile, she goes about her business, flying to and fro, carrying nesting material to the new nesting site on the other side of the tree.

01-05/03/1972. San Andrés de Cutervo, Cajamarca, 2400 m: Groups of up to $10 \mathrm{ind}$. at the edge of the humid montane forest.
Several nests hanging over the cliff above the cave of Steatornis caripensis. Several sightings of ind. carrying nesting material (on one occ. the fiber is about $1 \mathrm{~m}$ long). - Ind. drinking water from the cavities of a Bromeliaceae. Afterwards it plucks out some leaves, throws them away, goes on to the next plant, chooses the proper material carefully and flies away with it toward the nesting site above the cave.

01-06/10/1972. Laguna San Ango, Rio Pachitea near Yurimaguas, Loreto, $200 \mathrm{~m}$ : Common; nest-building activity in breeding colony. There is a constant coming and going. Birds arrive with new material (fibers up to $50 \mathrm{~cm}$ long), others depart in the opposite direction (there seems to be a unique source).

21/07/1983. Rio Negro, west of Rioja, San Martín, 800-1000 m: Several sightings in primary forest and plantations. Ind. on a bare tree with orange blossoms. It moves leisurely from one blossom to the next, dipping its bill into the calyx, then rises its head in a drinking manner.

\section{Cacicus chrysonotus}

18/09/1968. Rio Paucartambo, Pasco, 2600 m: 3 inds. roaming through secondary forest on a mountain slope.

\section{Icterus mesomelas}

07-09/07/1993. Chagual, Rio Marañón, La Libertad, 1200 m: Not rare; in scrub, dry forest and orchards. Pair on an Orthopterygium huacui tree. The male approaches the female with deep bows and steeply raised tail. The female responds with the same gestures. The courting ceremony takes place in silence and lasts a few minutes. - Group of 5-6 inds. on a fruit tree, warning and clamoring constantly. Melodic song: A rapid series of two-pitched sequences, consisting of 3-4 syllables.

\section{Dives warszewiczi}

Sightings.- Most records in Central Peru between 1500 and 2300 $\mathrm{m}$ (up to $3000 \mathrm{~m}$ ). Not recorded in the urban area of Lima until 2003

Voice/Courting.- Dives warszewiczi is one of the most avid singers of the west slope. Out of a total of 37 records, 27 are related to "song activity". The sonorous, gurgling song is occ. accompanied by bows or curtsies, especially when a female is present. D. warszewiczi sings year round. Nonetheless, song activity gets more intense in May, reaches its hight in July and lasts until Oct. A minor courting season occurs from Jan to March.

28/03/1964. Surco, Rímac Valley, Lima, 2300 m: Common; nest on an isolated Eucalyptus tree. Food-carrying ad., singing occ. with crammed bill. During the absence of the ad., the young occ. raise their heads above the rim of the nest.

06-12/06/1967. Chiuchín, Huaura Valley, Lima, 2600 m: Common in the cultivated areas of the valley and along stream. Food-carrying ind.

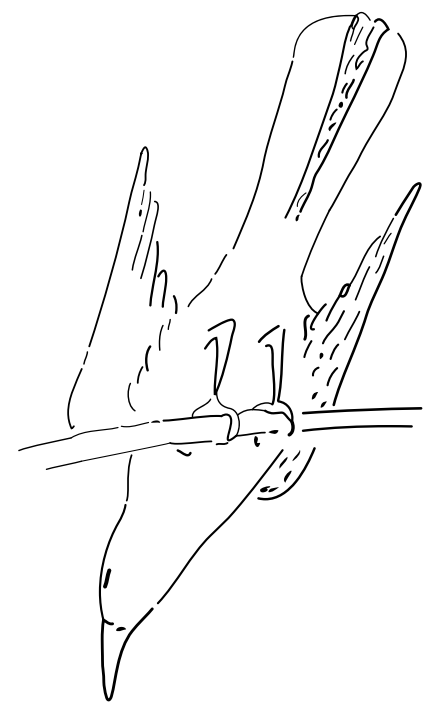

Figure 154. Psarocolius angustifrons: courting display. 


\section{Molothrus bonariensis}

Sightings.- Max. alt. on west slope: Haciendae Chuquizongo, Chicama Valley, La Libertad, 1400 m; on east slope between Cutervo and Sócota, Cajamarca, up to $\mathbf{2 2 0 0} \mathbf{~ m}$.

Behavior.- Gregarious; often in small groups or flocks of 10 to 20 inds., gathering by the hundreds at their roosting sites (totorales, parks). Often roaming about in separate groups of males and females, foraging on pastures among grazing cattle; single record of an ind. perched on horse's back.

Courting/Reproduction.- Song activity is most intense from July to Nov and to a lesser extent from Jan to Mar. Records of young, fed by their foster parents:

$$
\begin{aligned}
& \rightarrow \text { Volatinia jacarina 27/04/1963-11/04/1964 } \\
& \rightarrow \text { Zonotrichia capensis 07/03/1964 } \\
& \rightarrow \text { Troglodytes aedon 24/02/1965 }
\end{aligned}
$$

Judging from these dates, the main reproduction season is from February to April.

07/01/1968. Miraflores, Lima: Two females alight on a garden wall. They adopt an upright position, tail slightly cocked, wings hanging. After some steps, they return to the normal position. Before raising again, they bow deeply over the rim of the wall. During the ceremony, that lasts 2-3 min, the two remain in touch, pattering around in silence without taking notice of each other. The same ritual recorded Nov 72. - Similar behavior between two males (in presence of other males) Dec 72 and Jan 73.

10/01/1999. Miraflores: Three males (!) examining the nest of a breeding (momentarly absent) Zenaida meloda.

21/02/2003. Chiclayo, Lambayeque: Large numbers of $M$. bonariensis gathering at dusk on some trees lining a busy shopping street. New flocks arrive constantly and disappear in the dense foliage. Their twittering mingles with the noise of the traffic. Three bare trees are blackened with birds.

22/03/2003. San Borja/Lima: Female on a garden wall observes attentively a nearby pair of Volatinia jacarina. Occ. she curiously extends her neck.

\section{Sturnella bellicosa}

Sightings.- Coast from Tumbes to Tacna. Max. alt. San Luis, Callejón de Conchucos, Ancash, $3000 \mathrm{~m}$.

Habitat.- Fields, pastures, fallow land, lomas, totorales, estuaries, gramadales, scrub with cacti and trees, deciduous forest.

Voice/Behavior.- Melodious song, ending with very characteristic guttural sound, emitted from low perches or during descending phase of flight display. Song activity recorded from Aug to Mar.

08/06/1963. Villa, south of Lima: Numerous; flying to and fro between totoral and gramadal. Males perch on low elevations on the ground, from where they start their flight display. (04.09.63: Song activity until dusk)

27/11/1963. Lagunas de Chilca, $65 \mathrm{~km}$ south of Lima: Lively courting activity; food-carrying male.

24/08/1969. Lomas de Lachay, $70 \mathrm{~km}$ north of Lima, 400m: Numerous in high zone with lush vegetation; 5-6 singing males within a radius of $100 \mathrm{~m}$.

\section{FRINGILIDAE}

\section{Carduelis crassirostris}

Sightings.- Polylepis woods in Lima (Huaura Valley, Santa Eulalia Valley) and Ayacucho (slopes of Nevado Sarasara)

\section{Carduelis magellanicus}

\section{Sightings}

NP: west slope: 0-100 m/ 1500-2900 m; east slope: 2500 m/3400 m
CP: west slope: $0-3800 \mathrm{~m}$; there are two zones of higher population density: 0-1000 m and 2000-3500 m (only one record between 1000 and $2000 \mathrm{~m}$ ); east slope: $3000-3300 \mathrm{~m}$

SP: west slope: 3000-3700 m; east slope: $2300 / 3000 / 3400 \mathrm{~m}$

Voice.- Song: A hurried chatter on a modest tone scale. It may last - some short interruptions included - for a minute or more.

The diagram and the following records refer to the urban zone of

\begin{tabular}{|c|c|c|c|c|c|c|c|c|c|c|c|c|}
\hline & 1 & 2 & 3 & 4 & 5 & 6 & 7 & 8 & 9 & 10 & 11 & 12 \\
\hline$s$ & & & & - & & & $\ldots$ & $\ldots$ & $\cdots$ & $\cdots$ & $\ldots$ & \\
\hline $\mathrm{nb}$ & & & & & & & & & & | & & \\
\hline b & & & & & & & & & & & & \\
\hline ny & & & & & & & & | & & $\ldots$ & 11 & \\
\hline fo & & & & & & | & & & & 11 & & $\mid$ \\
\hline
\end{tabular}
Miraflores/Lima.

Preproductive periods of Carduelis magellanicus

Figure 155. 1-12: month/year; s: song activity; nb: nest-building; b: breeding; ny: nest with young; fo: feeding outside nest; | single record; --- observation period.

The courting season begins in July, reaches its height in Sep and lasts until Nov. The main breeding season is in Oct/Nov.

09/10/1963. Three nests in a row of Casuarinas bordering a sportsfield.

Nest I: About $7 \mathrm{~m}$ high on horizontal outer branches. Male approaches the unfinished nest with a 'mop' of cotton.

Nest II: At about the same height, but placed on the inner branches. Both sexes are present. Female settles on the nest and remains there for a few minutes.

Nest III: A thick-walled bowl about $4 \mathrm{~m}$ above ground with three nearly full-fledged young. In contrast to nest I and II, it is situated at a narrow angled crotch of the trunk. The outside consists mainly of Casuarina 'needles', grass stems and grass roots. The inside consists of cotton, some hairs and threads and a few feathers. Measures: Outer diam. $9 \mathrm{~cm}$, inner diam. $5 \mathrm{~cm}$, height $4,5 \mathrm{~cm}$, depth $3 \mathrm{~cm}$.

$03 / 11 / 1968$. Male in company of a young. The ad. is feeding on a Tagetes flower $(\rightarrow$ Feeding)). Later: Ad. and young on nearby garden wall, young begging with trembling wings. Ad. regurgitates a food package, releasing it in the wide open throat of the young.

October 1970. Brood about $6 \mathrm{~m}$ high on a Casuarina . Feedings recorded between the 13. and the 23. Oct. Both ads. participate. 24. Oct.: A full-fledged young leaves nest and lands safely on a lower branch.

Feeding.- Although C. magellanicus is predominantly a seed eater with a particular liking for Casuarina seeds in the Lima area, it feeds occ. on nectar: Pair shows up repeatedly in our garden, feeding on Tagetes. They cling to the swaying flower heads, plucking them to pieces. They pull off one petal after the other, sucking out the nectar (so it seems) of each of them in an amazing speed, then throw them away, petals whirling all around. The male 'consumed' 42 petals in one minute. The pair worked on the flowers for about ten minutes.

Pair appears occ. on a Spatodea campanulata. They feed on the plentiful seeds packed into the boat-like pods. Each seed is embedded in an extremely thin membrane. The birds pick up a package of seeds by either perching on the pod or if necessary approaching it from beneath by hovering. Carefully nibbling on the seeds, they manage to free them from the undesired membrane.

\section{Carduelis atrata}

Sightings.- Lima/Junín 3300-4400 m; Puno 3900-4100 m

24-25/04/1971. Chumcha, Stanta Eulalia Valley, Lima, 4100 m: Nest with fledglings at the edge of the Polylepis wood. It is well concealed in a tangle of roots of Gynoxys protruding from a cliff at 1,80 $\mathrm{m}$ above the ground. The thick walled, soft bowl, mainly made of moss, 
contains at least two (probably a few days old) fledglings. Feeding at 7 am on a cold, foggy morning. Ad. seems to regurgitate the food. After a minute it leaves the nest, its partner stays behind to protect the young. -Ind. with lichen-like nesting material on a Polylepis tree. Song activity begins at $6 \mathrm{am}$. The pleasent twitter consists of a series of clearly seperated two-syllable tones.

\section{Acknowledgment}

I would like to express my gratitude to Manuel Plenge for his support, to Claudia Lüthi and to Clare Juredieu for proof-reading the manuscript and to Wolfgang Hofmann for his companionship on so many birdwatching trips.

\section{Literature cited}

Fjeldså, J. \& Krabbe, N. 1990. Birds of the high Andes. Zoological Museum, University of Copenhagen and Apollo Books, Svendborg, Denmark. 880 pp.

Mayer A. 2011. Phenology and Citizen Science. BioScience. 60(3): 172-175.

Plenge M.A. 2010. (Online). List of the Birds of Peru. Lima, Peru. $<$ http://www.sernanp.gob.pe/sernanp/archivos/biblioteca/ publicaciones/Lista_\%20aves.pdf $>$ access 20/12/2010.

Schulenberg T.S., D.F. Stotz, D.F. Lane, J.P. O’Neill \& T.P. Parker III. 2007. Birds of Peru. Princeton University Press. 656 pp. 